\title{
IMPLEMENTATION OF CASE-BASED INSTRUCTION ON ELECTROCHEMISTRY AT 11TH GRADE LEVEL
}

A THESIS SUBMITTED TO

THE GRADUATE SCHOOL OF NATURAL AND APPLIED SCIENCES $\mathrm{OF}$ THE MIDDLE EAST TECHNICAL UNIVERSITY

BY

\author{
AYŞEGÜL TARKIN \\ IN PARTIAL FULFILLMENT OF THE REQUIREMENTS \\ FOR \\ THE DEGREE OF DOCTOR OF PHILOSOPHY \\ IN \\ SECONDARY SCIENCE AND MATHEMATICS EDUCATION
}



Approval of the thesis:

\section{IMPLEMENTATION OF CASE-BASED INSTRUCTION ON ELECTROCHEMISTRY AT 11TH GRADE LEVEL}

submitted by AYŞEGÜL TARKIN in partial fulfillment of the requirements for the degree of Doctor of Philosophy in Secondary Science and Mathematics Education Department, Middle East Technical University by,

Prof. Dr. Canan Özgen

Dean, Graduate School of Natural and Applied Sciences

Prof. Dr. Ömer Geban

Head of Department, Secondary Science and Math. Edu.

Assoc. Prof. Dr. Esen Uzuntiryaki Kondakçı

Supervisor, Secondary Sci. and Math. Edu. Dept., METU

\section{Examining Committee Members:}

Prof. Dr. Ömer Geban

Secondary Science and Mathematics Edu. Dept., METU

Assoc. Prof. Dr. Esen Uzuntiryaki Kondakçı

Secondary Science and Mathematics Edu. Dept., METU

Assoc. Prof. Dr. Yezdan Boz

Secondary Science and Mathematics Edu. Dept., METU

Assist. Prof. Dr. Hüseyin Akkuş

Secondary Science and Math. Edu. Dept., Gazi University

Assist. Prof. Dr. Ömer Faruk Özdemir

Secondary Science and Mathematics Edu. Dept., METU

Date: 28.08 .2014 
I hereby declare that all information in this document has been obtained and presented in accordance with academic rules and ethical conduct. I also declare that, as required by these rules and conduct, I have fully cited and referenced all material and results that are not original to this work.

Name, Last name : Ayşegül Tarkın

Signature 


\begin{abstract}
IMPLEMENTATION OF CASE-BASED INSTRUCTION ON ELECTROCHEMISTRY AT 11TH GRADE LEVEL
\end{abstract}

\author{
Tarkın, Ayşegül \\ Ph.D., Department of Secondary Science and Mathematics Education \\ Supervisor: Assoc. Prof. Dr. Esen Uzuntiryaki Kondakçı
}

August 2014, 269 pages

The main purpose of this study was to compare the effectiveness of case-based instruction over traditional instruction on eleventh grade high school students' understanding of electrochemistry concepts. In addition, the effect of instruction on students' attitudes toward chemistry, chemistry selfefficacy beliefs and motivation to learn chemistry were investigated.

The study was carried out during 2010-2011 spring semester in three Anatolian high schools in Ankara, Turkey. A total of 113 (47 males and 66 females) eleventh grade students from six classes of three chemistry teachers participated in this study. One of the classes of each teacher was randomly assigned as the experimental and control group. The experimental group was instructed by case-based instruction while the control group was taught by traditionally designed instruction.

Electrochemistry Concept Test, Attitude toward Chemistry Scale, High School Chemistry Self-efficacy Scale and Chemistry Motivation Questionnaire were administered as pre- and post-tests to students in both groups in order to measure the students' understanding of electrochemistry concepts, attitudes 
toward chemistry, self-efficacy beliefs (self-efficacy for cognitive skills and chemistry laboratory), and motivation to learn chemistry (intrinsic motivation and relevance of learning chemistry to personal goals). In addition, semistructured interviews were conducted with a total of twelve students from both the experimental and control groups to get deep infromation about students' understanding of electrochemistry concepts after the post-tests were administered. Moreover, a feedback form was administred to students in the experiemental group at the end of the study to get students' opinions about the case-based instruction.

The quantitative data were analyzed via descripitive and inferential statistics. One-way Multivariate Analysis of Variance (MANOVA) was used to determine the effect of case-based instruction on students' understanding of electrochemistry concepts, attitudes toward chemistry, self-efficacy for cognitive skills and chemistry laboratory, intrinsic motivation and perception about relevance of learning chemistry to personal goals. On the other hand, the qualitative data gathered from the interviews and feedback forms for casebased instruction were analyzed inductively. Results of MANOVA revealed that case-based instruction was an effective method to improve students' understanding of electrochemistry concepts, attitude toward chemistry, and intrinsic motivation to learn chemistry. The qualitative data also supported the results of inferential statistics.

Keywords: Case-based Instruction, Chemistry Education, Attitude toward Chemistry, Self-efficacy, Motivation to Learn Chemistry, Electrochemistry 


\title{
ÖRNEK OLAYA DAYALI ÖĞRETIMIN 11.SINIF ELEKTROKIMYA ÜNITESINDE UYGULANMASI
}

\author{
Tarkın, Ayşegül \\ Doktora, Ortaöğretim Fen ve Matematik Alanları Eğitimi Bölümü \\ Tez Yöneticisi: Doç. Dr. Esen Uzuntiryaki Kondakçı
}

Ağustos 2014, 269 sayfa

$\mathrm{Bu}$ çalışmanın temel amacı örnek olay temelli öğretme yönteminin onbirinci sınıf lise öğrencilerinin elektrokimya ile ilgili kavramları anlamalarına, kimya dersine karşı tutumlarına, özyeterlik inançlarına ve kimya öğrenmeye yönelik motivasyonlarına etkisinin geleneksel yöntem ile karşılaştırmaktır.

Bu çalışma 2010-2011 bahar döneminde Ankara'da bulunan üç anadolu lisesinde yürütülmüştür. Çalışmaya üç kimya öğretmeninin altı sınıfından 47si erkek 66sı kız olmak üzere toplam 113 onbirinci sınıf öğrencisi katılmıştır. Her öğretmenin sınıflarından biri deney diğeri kontrol grubu olmak üzere rastgele olarak atanmıştır. Deney grubundaki öğrenciler örnek olaya dayalı öğretim yöntemiyle öğrenirken kontrol grubundaki öğrenciler geleneksel öğretim yöntemiyle öğrenmişlerdir.

Öğrencilerin elektrokimya ile ilgili kavramları anlamalarını, kimya dersine karşı tutumlarını, özyeterlik inançlarını (bilişsel ve laboratuar kimya özyeterlik) ve kimya öğrenmeye yönelik motivasyonlarını (içsel motivasyaon ve kimya öğrenmenin kişisel hedeflerle ilişkisi) ölçmek üzere Elektrokimya 
Kavram Testi, Kimyaya Karşı Tutum Ölçeği, Kimya Özyeterlik Ölçeği ve Kimya Motivasyon Ölçeği her iki gurba öntest ve sontest olarak uygulanmıştır. Ayrıca, son testler uygulandıktan sonra, öğrencilerin elektrokimya kavramlarını anlamalarıyla ilgili daha derin bilgi elde etmek için deney ve kontrol grubundaki toplam oniki öğrenci ile yarı yapılandırılmış mülakatlar yapılmıştır. Bunların yanı sıra, çalışma sonunda deney grubundanki öğrecilerin örnek olaya dayalı öğretim yöntemi hakındaki düşüncelerini ortaya çıkarmak için bu öğrencilere geri bildirim formu dağıtılmıştır.

Nicel veriler betimsel ve çıkarımsal istatistik kullanılarak analiz edilmiştir. Örnek olaya dayalı öğrenme yönteminin öğrencilerin elektrokimya ile ilgili kavramları anlamalarına, kimya dersine karşı tutumlarına, bilişsel ve laboratuar özyeterlik inançlarına ve içsel motivasyonlarına ve kimya öğrenmeyi kişisel hedeflerle ilişkilendirmelerine etkisini araştırmak için Çoklu Varyans Analizi (MANOVA) kullanılmıştır. Diğer taraftan, mülakatlardan ve geri bildirim formalarından elde edilen nitel veriler tümevarım yöntemiyle analiz edilmiştir. MANOVA sonuçları örnek olaya dayalı öğretme yönteminin geleneksel yönteme kıyasla öğrencilerin elektrokimya konusunu anlamalarını, kimya dersine karşı tutumlarını ve kimya öğrenmeye yönelik içsel motivasyonlarını arttırmada etkili bir yöntem olduğunu göstermiştir. Nitel veriler de çıkarımsal analiz sonuçlarını desteklemektedir.

Anahtar Kelimeler: Örnek Olaya Dayalı Öğretim, Kimya Eğitimi, Kimyaya yönelik Tutum, Özyeterlik, Kimya Öğrenmeye Yönelik Motivasyon, Elektrokimya 


\section{ACKNOWLEDGEMENTS}

I would like to express my heartfelt thanks and deepest gratitude to my supervisor Assoc. Prof. Dr. Esen Uzuntiryaki Kondakçı, who was a plesaure to work with. Her guidance and support provided along the way with this dissertation were invaluable. Thank you for sharing so much of time to help me complete this dissertation.

I also would like to thank my disserttation committe members Assoc. Prof. Dr. Yezdan Boz and Assist. Prof. Dr. Hüseyin Akkuş for being so insightful and hepful. I greatly appreciate all of the contribution and guidance in helping me complete this study.

Also, I want to thank Prof. Dr. Ömer GEBAN, head of Secondary Science and Mathematics Education (SSME) department, for his kindness, encouragement, and way of behaving to us. I always feel myself special as a member of SSME family.

I am deeply grateful to all my friends who were always being there whenever I need a help. Thanks to you all for the wonderful support, advice and friendship. Particularly, I would like to give special thanks to Sevgi Aydın, Betül Demirdöğen, Mustafa Tüysüz, Oktay Bektaş, Betül Ekiz, Elif Selcan Kutucu, Kübra Eryurt, and Fatma Nur Akın, Sevgi İpekçioğlu. Thank you for believing in me even when I doubted myself. Your moral support and encouragement helped me to complete this dissertation. I could not have completed this without all your support throughout the study. The jokes and laughter we shared helped me to continue.

And my family... I wish to express my gratitude to my mother, father and brother, Saliha, Feramuz and Zeynel Özcan Tarkın. Thank you so much for your endless love and patience although I could not always create enough time 
to spend with you. This study would not be ended without your encouragement, support and love.

Finally, I would like to also acknowledge The Scientific and Technological Research Council of Turkey (TUBITAK) for financial support during the PhD study through the National Scholarship Program coded as 2211. Also, special thanks to the program (ÖYP) that I enrolled to. 
TABLE OF CONTENTS

ABSTRACT

\section{CHAPTERS}

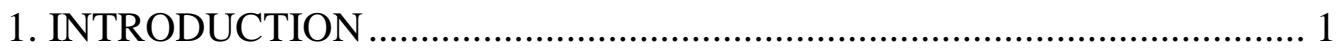

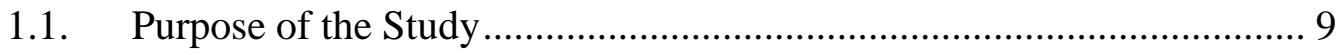

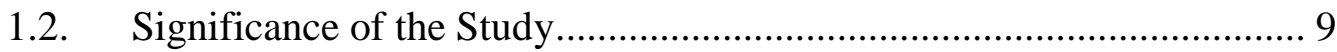

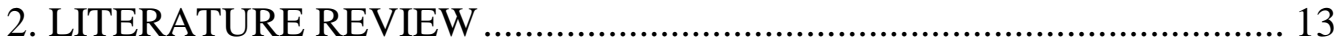

2.1. Theoretical Base of Case-Based Instruction: Constructivism .............. 13

2.2. History of Case-Based Instruction..................................................... 18

2.3. Case-Based Instruction ...................................................................... 20

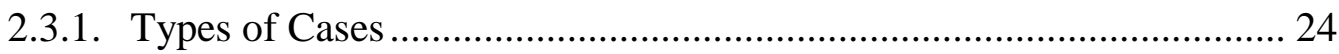

2.3.2. Advantages of Case-Based Instruction .............................................. 32

2.3.3. Disadvantages of Case- Based Instruction .......................................... 33

2.4. Attitude toward Science.................................................................... 34

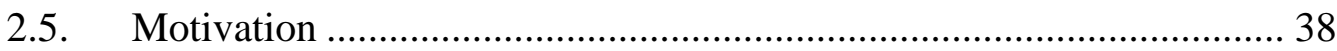

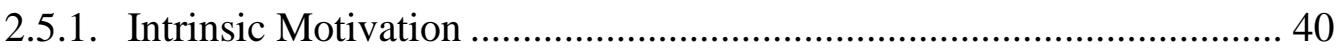

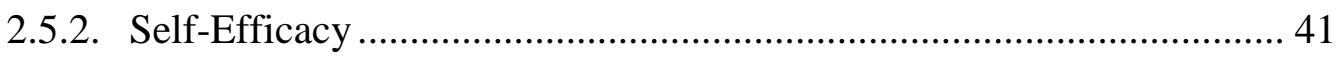

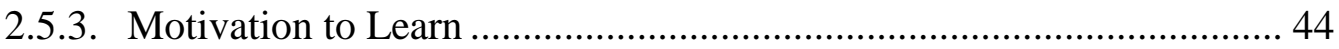

2.6. Students' Understanding of Electrochemistry .................................. 47

2.7. Research on the Case-Based Instruction in Science Education............ 51

2.7.1. Research on The Case-Based Instruction in Undergraduate Science Education 
2.7.2. Research about the Case-Based Instruction on High School and Elementary School Science Education ..............................................67

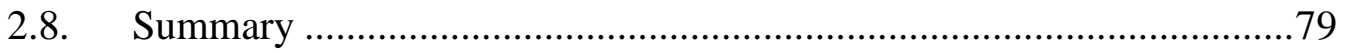

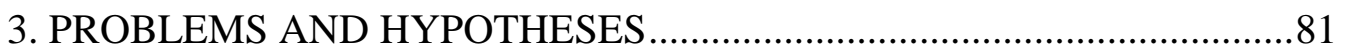

3.1. The Main Problem and Sub-Problems ….............................................8 81

3.1.1. The Main Problem ..........................................................................8

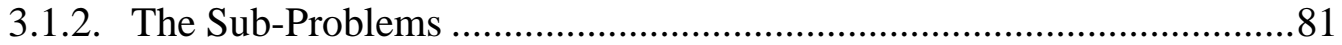

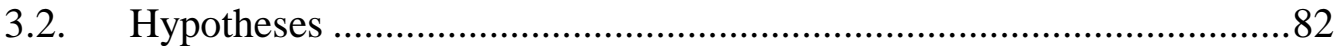

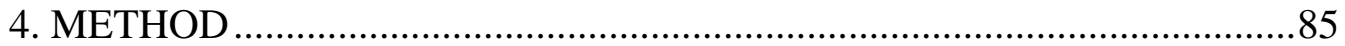

4.1. Research Design of the Study: Experimental Design .........................85

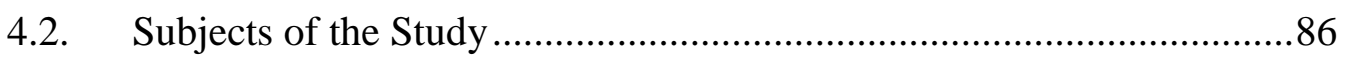

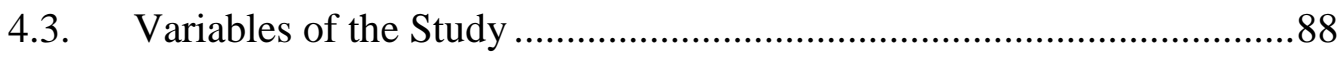

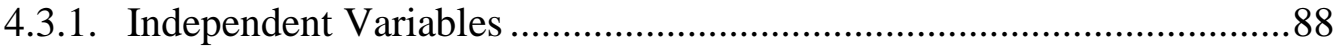

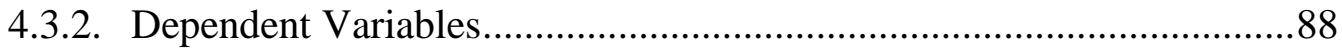

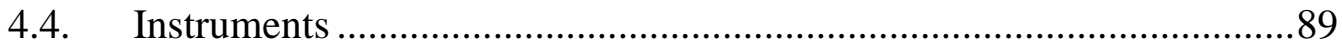

4.4.1. Electrochemistry Concept Test (ECT) ................................................89

4.4.2. Attitude Scale toward Chemistry .........................................................92

4.4.3. Chemistry Motivation Questionnaire ....................................................93

4.4.4. High School Chemistry Self-Efficacy Scale .......................................95

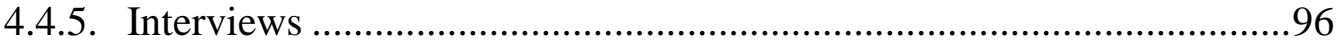

4.4.6. Feedback Form for the Case-Based Instruction ...................................97

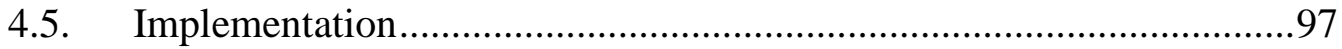

4.5.1. Treatment in the Control Groups ........................................................... 101

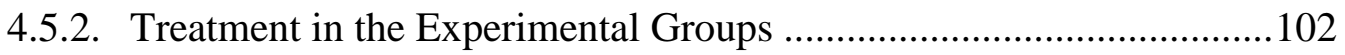

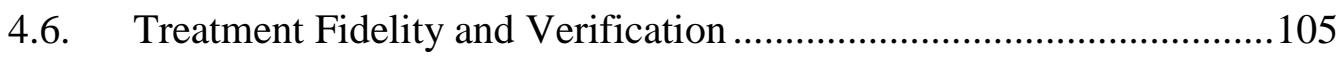

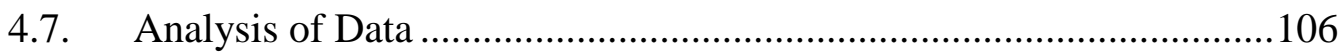

4.8. Threats to Internal Validity .............................................................108

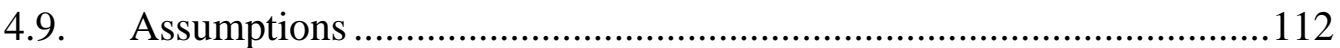

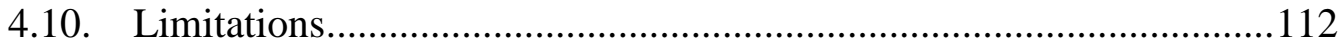

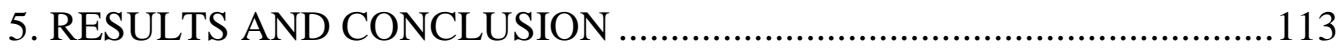


5.1. Analyses of the Pre-Tests Scores ................................................ 113

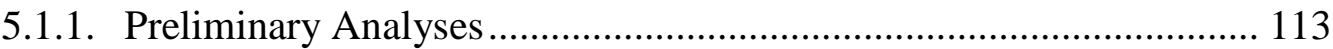

5.1.2. Checking the Assumptions of MANOVA for The Pre-Test Scores ... 116

5.1.3. Results of MANOVA for the Pre-Test Scores .................................. 125

5.2. Analyses of the Post-Tests Scores …............................................... 129

5.2.1. Preliminary Analyses ................................................................... 129

5.2.2. Checking Assumptions of MANOVA for the Post-Test Scores ........ 131

5.2.3. Results of MANOVA for the Post-Tests Scores .............................. 139

5.3. Results of Student Interviews ......................................................... 146

5.4. Students' Opinions about Case-Based Instruction ............................ 171

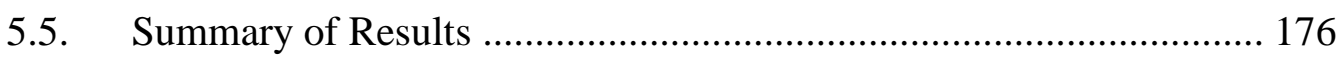

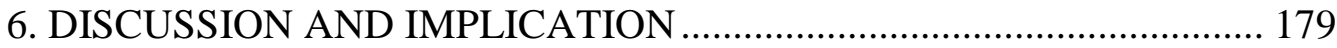

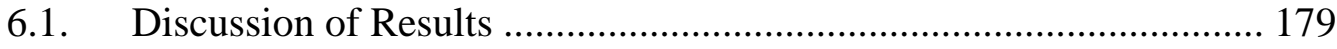

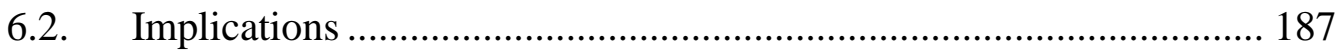

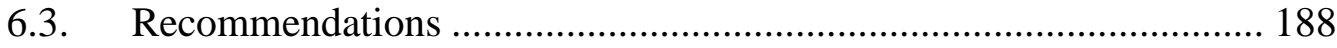

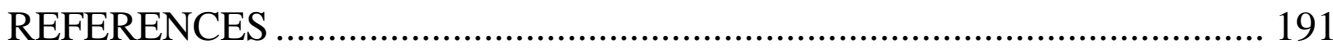

APPENDICES

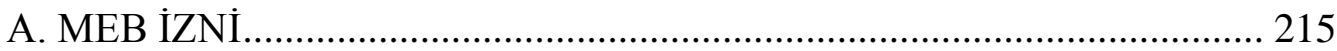

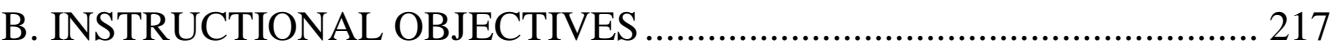

C. ELECTROCHEMISTRY CONCEPT TEST (PILOT).............................. 219

D. ELECTROCHEMISTRY CONCEPT TEST (FINAL FORM)................. 231

E. TABLE OF TEST SPECIFICATION.................................................... 243

F. ATTITUDE SCALE TOWARD CHEMISTRY ….................................... 245

G. CHEMISTRY MOTIVATION QUESTIONNAIRE ............................... 247

H. HIGH SCHOOL CHEMISTRY SELF-EFFICACY SCALE ................... 249

I. FEEDBACK FORM FOR CASE-BASED INSTRUCTION ................... 251

J. A SAMPLE CASE (STUDENT VERSION) ......................................... 255

K. A SAMPLE CASE (TEACHER VERSION) ......................................... 257

L. CLASSROOM OBSERVATION CHECKLIST ..................................... 263

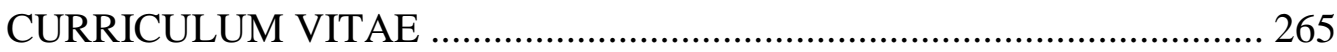




\section{LIST OF TABLES}

\section{TABLES}

Table 1 Studies in which students' understanding in electrochemistry was

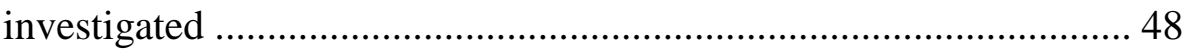

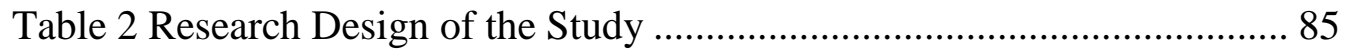

Table 3 Distributions of Classes with Respect to Teachers and Instructional Method 87

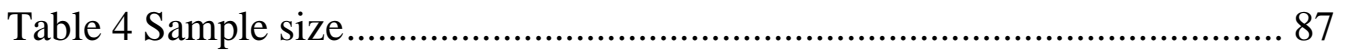

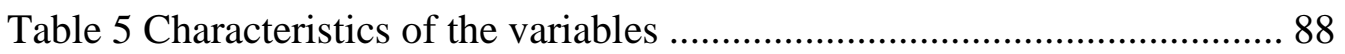

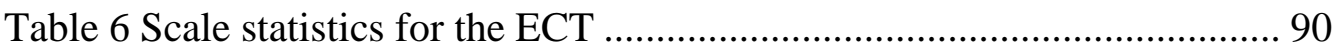

Table 7 The results of classroom observation checklist............................... 105

Table 8 Descriptive Statistics for Pre-tests Scores ...................................... 118

Table 9 Correlations among the dependent variables for the pre-test scores 124

Table 10 Box's M Test of Equality of Covariance Matrices ......................... 124

Table 11 The results of one-way MANOVA for the pre-test scores............. 121

Table 12 Result of univarite tests for the between-subject effects of one-way

MANOVA for the pre-tests scores................................................. 126

Table 13 Descriptive Statistics for Post-tests Scores .................................. 132

Table 14 Correlations among dependent variables for the post-test scores ... 138

Table 15 Box's M Test of Equality of Covariance Matrices ........................ 139

Table 16 The results of one-way MANOVA for the post-test scores ............ 139

Table 17 Levene's Test of Equality of Error Variances ............................... 140

Table 18 Result of univarite tests for the between-subject effects of one-way MANOVA for the post-tests scores ................................................ 142 


\section{LIST OF FIGURES}

\section{FIGURES}

Figure 1 Cone of Learning and Case Methods ............................................. 30

Figure 2 An orange-juice clock setup with metal wires................................. 97

Figure 3 Box plots for each dependent variable .......................................... 115

Figure 4 Box plots for each dependent variable ........................................ 130

Figure 5 The bar chart of the percentages of students' correct and wrong answers on the post-ECT ............................................................. 147 


\section{LIST OF ABBREVIATIONS}

\begin{tabular}{|c|c|}
\hline CG & : Control Group \\
\hline EG & : Experimental Group \\
\hline MANOVA & : Multivariate Analysis of Variance \\
\hline ANOVA & : Analysis of Variance \\
\hline ANCOVA & : Analysis of Covariance \\
\hline $\mathrm{N}$ or $\mathrm{n}$ & : Sample size \\
\hline $\mathrm{F}$ & : F Statistics \\
\hline $\mathrm{P}$ & : Significance Value \\
\hline Df or df & : Degrees of Freedom \\
\hline$X^{2}$ & : Chi-square \\
\hline $\mathrm{R}$ & : Pearson correlation coefficient \\
\hline Std. Dev. & : Standard Deviation \\
\hline Std. Error & : Standar Error \\
\hline SPSS & : Statistical Package for Social Sciences \\
\hline AMOS & : Analysis of Moment Structures \\
\hline ITEMAN & : Item and Test Analysis \\
\hline CFI & : Comparative Fit Index \\
\hline NFI & : The Normed Fit Index \\
\hline RMSEA & : Root-Mean-Square Error of Approximation \\
\hline IGO & : Intrinsic Goal Orientation \\
\hline EGO & : Extrinsic Goal Orientation \\
\hline TV & : Task Value \\
\hline CLB & : Control of Learning Beliefs \\
\hline SELP & : Self-efficacy for Learning and Performance \\
\hline TA & : Task Anxiety \\
\hline SEM & : Standard Error of Measurement \\
\hline ECT & : Electrochemistry Concept Test \\
\hline
\end{tabular}


xviii

ASTC : Attitude Scale toward Chemistry

CMQ : Chemistry Motivation Questionnaire

SMQ : Science Motivation Questionnaire

HCSS : High School Chemistry Self-Efficacy Scale

TUBITAK : The Scientific and Technological Research Council of Turkey 


\section{CHAPTER 1}

\section{INTRODUCTION}

Although different countries include different science content in their science curriculum or suggest different teaching methods for an effective science instruction, promoting meaningful learning of science is one of the most highlighted goals of science education (Michael \& Modell, 2003). Meaningful learning means learning by understanding not by memorizing. It goes far beyond knowing definition of concepts and principles. Rather, meaningful learning occurs when students can use what they learned to explain or explore new situations (Krajcik \& Czerniak, 2007; Roth, 1990). Ausubel (1968) defined meaningful learning as learning of ideas, concepts, and principles by building knowledge on the basis of what is already know. Meaningful learning enhances the retention and utilization of knowledge in different contexts (Michael \& Modell, 2003). In science education, students are required to be able to comprehend scientific ideas, concepts and principles and apply those to understand their environment, explain environmental phenomena and solve real-world problems they would face in their daily life (Briscoe \& LaMaster, 1991; Krajcik \& Czerniak, 2007). In addition to be knowledgeable about scientific facts and principles, science education aims to improve students' attitude toward science. Attitude is defined as positive or negative feelings about a person, an object or an issue (Koballa \& Glynn, 2007). Regarding students' attitude toward science, they are expected to manifest favorable attitudes towards science and scientists; to accept scientific inquiry as a way of thought; to enjoy science learning experiences; to develop interests in science and science-related activities; to develop an interest in 
pursuing a career in science or science related work; and to adopt 'scientific attitudes', which means possessing curiosity, objectivity, open-mindedness, perseverance, humility, ability to accept failure, intellectual honesty, skepticism, etc. (Osborne, Simon, \& Collins, 2003).

Promoting meaningful learning and positive attitudes toward science play essential role in development of scientifically literate citizens. A scientifically literate citizen is a person who understands the natural world and scientific enterprises, uses appropriate scientific knowledge, principles and processes in making his/her decisions, engages intelligently in public discourse and debates about science-related public issues such as environment, health, energy, and food (National Research Council, 1996). For example, while debating about social issues such as global warming, people need their prior science knowledge. In addition, a person having positive attitude toward science uses eco-friendly fuels such as unleaded gasoline in his/her car to save the environment. Therefore, science educators should put more emphasis on enhancement of meaningful learning and positive attitude toward science during science education.

The nature of science instruction has an important role in promoting students' meaningful learning of science. The findings of research studies over twenty years indicated that traditional instruction, which is mainly based on teacher-centered approach and involves simple transition of knowledge from teacher to students, was ineffective to engage students in meaningful learning in different areas of science such as biology and chemistry (Aikenhead, 2003; Anderson \& Lee, 1997; Anderson \& Smith, 1987; Haider \& Abraham, 1991; Lord, 1999; Mao \& Chang, 1998; McDermott, 1993; Schroeder, Scott, Tolson, Huang, \& Lee, 2007). Particularly in chemistry, students experience lots of difficulty in understanding the concepts (De Jong \& Taber, 2007; Duit \&Treagust, 1998; Harrison \& Treagust, 1996; Nakhleh, 1992; Sirhan, 2007). In addition, they view chemistry as a boring subject and irrelevant to their life (Hutchinson, 2000; Soudani, Sivade, Cros \& Medimagh, 2000). It appeared 
that traditional instruction is not adequate for increasing meaningful learning and arousing interest in chemistry. Students generally see the scientific facts, definitions, and formulas as school knowledge and memorize them to pass their science exams. They could not apply their knowledge to explain real-world phenomena that they observe and experience (Roth, 1990). In the literature, two of the most outstanding criticisms of the science education are its lack of relevance to daily life and its focus on abstract concepts beyond the interest of students (Dillon, 2009; Rannikmäe, Teppo \& Holbrook, 2010).

Over the last twenty years, it has become clearer to science educators that constructivist approaches facilitate producing meaningful understanding of science (Barron \& Darling-Hammond, 2008; Duit \&Treagust, 1998; Leonard, 2000). Constructivist approach emphasizes that meaningful learning is an active construction process in which learners construct their knowledge by being actively involved in learning environment rather than receiving knowledge from teacher. Leonard (2000) stated that when a student is actively involved (physically, emotionally, and mentally) in learning process, s/he will have a deeper understanding of concepts and retain that understanding longer than when the learning experience is passive. In constructivist approach, instructors' role is facilitator rather than providers of knowledge, and students' prior knowledge and active participations are at the heart of the meaningful learning process (Mayer, 1999). In addition, Honebein (1996) explained that constructivist approach situated learning tasks in realistic and relevance contexts, and embedded learning in a social interaction, and learners take an active role in the process of their own knowledge construction. Therefore, this approach is more likely to contribute to the increase in student interest in science and likely to improve their views about the relevance of science to their life, which enhances their scientific literacy at the end (King, 2009).

Case-based instruction allows students to construct their knowledge and pays importance to authentic, meaningful, and active learning as proposed by constructivist approach (Guest, 2007). It creates an active learning environment 
that involves students in solving and examining real-world problems in small groups with guided instruction. In other words, it enhances students to recognize a wide range of applicable social problems and concerns and provides them with opportunities to solve them in a collaborative environment. The role of the instructor is to provide appropriate cases and guide learning through asking appropriate questions that promote analysis, discussion, and resolution for the specific problem given in the case. Thereby, it helps learners to put their theoretical knowledge into practice and to see the relevance of the subject taught to their life rather than merely memorizing a prescribed body of knowledge. Moreover, case-based instruction makes the classroom environment vigorous and more engaging than traditional instruction because students are involved in trying to put ideas into their own words while studying cases (Herreid, 2005). Furthermore, this method increases retention of science learning (Cornely, 1998). In science education literature, research studies indicated that case-based instruction enhanced students' problem solving, higher order thinking, decision making and critical thinking skills (Cornely, 1998; Herreid, 1994; 2007; Rybarczyk, Baines, McVey, Thompson, \& Wilkins, 2007). Moreover, case-based instruction helps students develop essentials skills for their future career such as communication, teamwork skills, and collaborative skills through building knowledge and solving problems collectively as a group (Jones, 2003; Morrison, 2001).

Case-based instruction was firstly used in the Law and Business Schools at Harward College around a hundred years ago (Herreid, 2005). While case-based instruction has long been used in law and business, it is increasingly used in other disciplines such as health science (Brown, et al., 2011; Dupuis \& Persky, 2008), nursing (Kaddoura, 2011; Thomas, O’Connor, Albert, Boutain, \& Brandt, 2001), business management (Pearce, 2002) psychology (Mayo, 2002; 2004) and educational psychology (Sudzina, 1997). Recently, it has been used in science education. For about 20 years, many instructors of various scientific disciplines have adapted the case-based 
instruction to their courses such as environmental chemistry (e.g., Cheng, 1995), general chemistry (e.g., Hutchinson, 2000; Jones, 1997), general biology (e.g., Rybarczyk et al., 2007) anatomy and physiology (e.g., Cliff \& Wright, 1996; Wilcox, 1999), and biochemistry courses (e.g., Cornely, 1998). Many of these studies presented applications of case-based instruction during undergraduate courses stated above, and students' ideas about these courses and usefulness of case-based instruction (Challen \& Brazdil, 1996; Cheng, 1995; Cornely, 1998; Jones, 1997; Lantz \&Walczak, 1997; Smith \&Murphy, 1998; Wilcox, 1999). In the literature, there were also studies that explored not only students' views about case-based instruction but also the interaction between their views and other variables such as levels of self-regulation (Ertmer, Newby \& MacDougall, 1996). In addition, some studies examined the effectiveness of case-based instruction on students' learning and attitudes toward the course via one group research design (Ayyildiz \& Tarhan, 2012; Hutchinson, 2000; Knight, Fulop, Marquez-Magana, 2008). To my best knowledge, only Rybarczyk et al. (2007) conducted an experiemental research study to investigate the effectiveness of case-based learning approach on students' learning gain in an undergraduate course. Regarding research studies conducted in elementary and high school courses, some studies presented the way they used cases in the courses (Richmond \& Neureither, 1998) similar to the other studies conducted in the undergraduate courses. Moreover, some studies investigated the effect of case-based instruction on different variables through experimental research design in the context of different courses such as science (e.g., Adali, 2005; Gabel, 1999), biology (e.g., Cakir, 2002; Saral, 2008; Skolnick, 2009), physics (e.g., Ozkan \& Azar, 2005), and chemistry (e.g., Cam, 2009; Morris, 2013; Yalcinkaya, 2010). In conclusion, research studies investigating the impact of case based instruction on students' learning are limited. Moreover, case-based instruction has had little trial among teachers in secondary science education, especially chemistry teachers. Therefore, the 
effect of case-based instruction on secondary science students' learning needs to be studied as there is little empirical research in this area.

Affective variables such as attitude and motivation have been regarded as a salient factor affecting student learning in science $(\mathrm{Ng}$, Lay, Areepattamannil, Treagust, \& Chandrasegaran, 2012; Singh, Granville, \& Dika, 2002). Regarding chemistry learning, the study conducted by $\mathrm{Xu}$, Villafane and Lewis (2013) showed that students' achievement in chemistry could be improved not only by focusing on building conceptual knowledge, but also by fostering students' positive attitude toward chemistry. Attitude toward science is also important for students to enroll more advanced science courses and to choose science-related careers in the future. According to Raved and Assaraf (2011), one of the factors influencing students' attitudes toward science is the relevance and authenticity of the topics being studied.

In addition to positive attitude towards science, another affective variable, motivation, has been reported to be related to student learning (Pintrich, 2003; Pintrich \& Schunk, 2002). Motivation is defined as the process that initiates and sustains goal-oriented activities. In other words, motivation stimulates individuals start on an activity, keep them moving, and help them accomplish the activity (Pintrich, 2003; Pintrich \& Schunk, 2002). Students should engage in a learning task to learn. For this engagement, their interest in learning task or enjoyment of it, importance and usefulness of the task for students' future goals are important. When students are interested in learning task, and enjoy and value it, they work on the task and persist in working on it even if they encounter difficulties. Case-based instruction is likely to be effective in increasing students' attitudes toward science and their motivation because students actively engage in learning as a group. Furthermore, casebased instruction provides opportunities for students to experience or practice real life situations and to perceive relevance of science. In general, students find this instructional strategy as realistic, challenging, interesting, enjoyable, and encouraging for learning (Bridges \& Hallinger, 1999; Dori \& Herscovitz, 
1999; Herreid, 2006; Jones, 1997; Mayo, 2002; 2004; Naumes \& Naumes, 2006; Smith \& Murphy, 1998; Wassermann, 1994). However, there is little empirical research on the effectiveness of case-based instruction on students' motivation and attitude toward science such as studies conducted by Cam (2009), Saral (2008), Skolnick (2009) and Yalcinkaya (2010). Findings of these studies indicate that case-based instruction promotes intrinsic and extrinsic motivation and students find the learning tasks more valuable than students instructed with traditionally designed instruction. Still, further research is warranted to provide empirical evidence for the effect of case-based instruction on students' motivation and attitude at different grade and branches of science.

The last affective variable of the study is self-efficacy, which also has influence on students' science learning (Andrew, 1998; Britner \& Pajares, 2001; Kupermintz, 2002). Self-efficacy is defined as "people's judgments of their capabilities to organize and execute courses of action required to attain designated types of performances" (Bandura, 1986, p.391). Students' science self-efficacy beliefs affect their tendency to engage in science learning activities, their efforts to complete them, and their persistence in working when they encounter difficulties. Students perform science activities which they believe they have capability to do well and avoid tasks which they believe they could not do (Bandura, 1997; Britner \& Pajares, 2001). Bandura (1997) stated that students interpret the results of their previous experience with the task and develop beliefs about their capability. In particular, students' successful experiences in executing a task will increase their self-efficacy while failures will decrease. In order to enhance student learning and engagement in science, self-efficacy construct should be considered by teachers. Bandura (1997) proposed that self-efficacy beliefs are shaped by four main sources of information: mastery experience, vicarious experience, social persuasion, and physiological states. The case-based learning environment has potential to provide mastery and vicarious experiences by engaging students in solving 
authentic problems and working collaboratively, and therefore, is likely to promote students' science self-efficacy (Dunlap, 2005).

Chemistry is one of the most important branches of science and its relevance to our life and environment is limitless. For example, electrochemistry concepts are related to many daily life events. Batteries used in many electronic tools (e.g., mobile phones, calculators, and clocks), metal plating used in industry, photosynthesis and respiration involve oxidationreduction reactions. Moreover, electrochemistry concepts explain process of environmental events such as acid rain, corrosion of metals, water purification by chlorination, and energy production. On the other hand, electrochemistry is one of the chemistry subjects which were seen as difficult by students (Finley, Stewart \&Yarroch, 1982; Johnstone, 1980; Butts \& Smith, 1987; Soudani, et al., 2000). Mainly, students had difficulty in applying their theoretical knowledge about oxidation-reduction concepts in interpreting daily life events. Soudani et al. (2000) propose some factors which may be responsible for student difficulties in electrochemistry: teachers' focus on algorithmic problem solving rather than students' understanding of their environment; students' unawareness of the relevance of chemistry with their life and environment; students' lack of curiosity about chemistry learning; and students' focus on only getting the best grades to move up into higher classes which directs them to rote learning rather than deep understanding of concepts. Case-based instruction might be helpful for students to understand electrochemistry concept since the activities related to daily life events will attract students' interest and curiosity to chemistry learning and increase their awareness of the relevance of chemistry to their life and environment. Thus, this kind of instruction might be effective in promoting meaningful learning of electrochemistry concepts and improve students' scientific literacy. 


\subsection{Purpose of the Study}

The purpose of this study was to compare the effectiveness of casebased instruction and traditionally designed chemistry instruction on $11^{\text {th }}$ grade students' understanding of the electrochemistry concepts. In addition, the effect of instruction on their attitudes, self-efficacy beliefs, and motivation in chemistry were examined.

\subsection{Significance of the Study}

Over the past twenty years, science educators have emphasized that learners should construct their knowledge by actively involving in a realistic and social learning environment rather than receiving knowledge from the teacher. Although many researchers have designed various instructional strategies and investigated their effects on students' science learning, new ways for teaching science effectively are still among science educators' field of interest. Recently, one of the instructional strategies called case-based instruction which has a long history and being widely used in law, business and health science has been used in science education. Case-based instruction creates an active learning environment that involves solving and examining real-world problems in small groups with guided instruction. In addition, casebased instruction was found to be effective in developing students' problem solving, communication, teamwork and collaborative skills which are essentials skills for their future careers. Considering all of those advantages of case-based instruction, in the present study, I utilized this method in a chemistry context in which literature contains limited number of studies. More specifically, the impact of case-based instruction on promoting meaningful chemistry learning was investigated in the present study.

Science education does not only deal with teaching some theoretical knowledge but also provide ways to students in gaining basic affective and motivational skills (Koballa \& Glynn, 2007). For example, science education should help students enhance their communication with others, possess positive 
attitudes toward science and learning, get interest and persist on studying on a learning task, and be intrinsically motivated to learning. The literature provides evidence that case-based instruction was effective in terms of engaging students in learning tasks, attracting their interest in learning, making them enjoy during classes, and motivating them to learning (Bridges \& Hallinger, 1999; Dori \& Herscovitz, 1999; Herreid, 2006; Jones, 1997; Mayo, 2002; 2004; Naumes \& Naumes, 2006; Smith and Murphy, 1998; Wassermann, 1994). Although case-based instruction has been studied for classroom setting in science, its implementation in chemistry education is rare. In the present study, therefore, case-based instruction and traditional instruction were compared to determine their effects on students' understanding of the electrochemistry concepts, their attitudes, self-efficacy beliefs and motivation in chemistry.

In chemistry education, one of the major concerns is that students do not see the importance and relevance of learning chemistry concepts for themselves (Hutchinson, 2000). They thought that learning these concepts is required for only the next step in their education (Pilot \& Bulte, 2006; Soudani, et al., 2000). Many students consider the knowledge that they learned in chemistry classes as isolated from their everyday life since it seems not be useful in their everyday life (Soudani, et al., 2000). School chemistry should need to build theoretical knowledge on basis of everyday life and realistic context in order that students have conceptual understanding of science concepts and see the link between chemistry and environmental phenomena. Regarding this point, case-based instruction might be effective to bring the learning of chemistry closer to the students' lives and interests and to reveal how the use of real life examples would develop their interest in science and so improve their understanding and scientific literacy.

Studies that address effectiveness of instructional strategies on promoting meaningful learning have the potential to inform both researchers and teachers. By providing empirical evidence, this study will enlighten 
researchers, in the field of chemistry education, about the effectiveness of casebased instruction on students' understanding of chemistry concepts, their attitudes, self-efficacy beliefs and motivation in chemistry. On the other hand, this study will inform chemistry teachers about implementation of case-based instruction designed to promote meaningful learning in chemistry education and to improve students' attitudes, self-efficacy beliefs and motivation in chemistry by providing detailed information about case-based instruction and teaching materials prepared on the subject of electrochemistry. 


\section{CHAPTER 2}

\section{LITERATURE REVIEW}

This chapter presents the theoretical background of case-based instruction and describes history and characteristics of case-based instruction. In addition, affective variables of the study, particularly motivation, selfefficacy, and attitude constructs, are explained in this part. After description of case-based instruction and affective variables, the literature review on the effectiveness of case-based instruction on students' understanding, attitude, self-efficacy, and motivation in chemistry is presented in this part. Lastly, a summary of literature review on case-based instruction is provided.

\subsection{Theoretical Base of Case-based Instruction: Constructivism}

Constructivism is a psychological and philosophical perspective which explains how learners construct knowledge. It has been proposed as an alternative approach to behaviorist learning approach that focuses the transmission of knowledge from teacher to learner (Bodner, Klobuchar, \& Geelan, 2001; Schunk, 2000). The main assumption of constructivism is that learners have an active role in the learning process by constructing their own knowledge. In other words, from constructivist point of view, "knowledge is constructed in the mind of the learner" (Bodner, 1986, p.1). According to constructivist view of learning, learners are not empty vessels to be filled in instead they construct their own knowledge based on their prior knowledge and experiences (Driver \& Bell 1986; Driscoll, 2005). In addition, the constructivist view criticizes objectivism which refers that knowledge is a reflection of ontological reality and it only focus on the constructed reality. 
Constructivism holds the view that the purpose of knowledge construction is an individual's adaptation to the world; not the discovery of an objective ontological reality. The only reality is that which is constructed by the individual. We can never access to a world of reality since we cannot conclude that all people knowledge is the same (Elizabeth, 1997; Goldin, 1990; Matthews, 2003; Staver, 1998).

The roots of constructivism can be traced back to the writings of Greek philosophers such as Socrates. Socrates believed that the role of teacher was questioner and questions led learners use their prior knowledge. Today, this teaching method is called as Socratic Method. Explicitly, the notion of constructivism is rooted mainly in Piaget's ideas of cognitive development (Glaserferd, 1993). For Piaget (1952), cognitive development of human is explained by schemes, assimilation, and accommodation. Individuals organize information acquired from the environment as cognitive structures which is called schemes and adjust their existing schemes in response to the environment by means of assimilation and accommodation. This adjusting process is called as adaptation. If the old scheme works properly with the new information, the new information is placed into existing schemes. This process called as assimilation. On the contrary, if old scheme does not work with the new information, this creates a state of disequilibrium between scheme and understanding from environment. As a result of disequilibrium, existing scheme is modified or a new scheme is created by the individual, which is called as accommodation. After accommodation process, a new equilibrium is established (Driscoll, 2005; Piaget, 1952; Schunk, 2000). As a result of those processes, individuals construct knowledge. In addition, Piaget believed that cognitive development should be completed before learning. In other words, according to Piaget, development precedes learning (Gallagher \& Reid, 1981).

Throughout the literature, the active and interpretive knowledge construction, and idiosyncratic structuring of knowledge are held commonly by all constructivists (Billet, 1998). However, in addition to these views, there are 
different perspectives of constructivism focusing on different aspects of the process by which learning occurs. Geelan (1997) described the six forms of the constructivism: personal constructivism, radical constructivism, social constructivism, contextual constructivism, social constructionism, and critical constructivism. Piaget's view of learning is called as personal constructivism or Piagetian constructivism (Bodner, Klobuchar, \& Geelan, 2001). Personal constructivism emphasizes the individual construction of the knowledge through making sense of experiences of individual within the world. In other words, knowledge is constructed by the learner rather than by transmitting from one person to another (Geelan, 1997). In addition, personal constructivists relate all knowledge to the ontological reality of the external world.

Radical constructivism is associated with the work of Ernst von Glasersfeld (1995). His view of constructivism focuses on two principles. Similar to personal constructivism, he emphasized that knowledge is not passively received but actively constructed within the learner mind. In addition to this idea, he claimed that all knowledge is constructed for the purpose of maintaining viability through making sense of the experience rather than discovering truth about the real world (Geelan, 1997). With this idea, radical constructivists differ from personal constructivists. While accepting that knowledge is held by individual, social constructivism emphasizes that the social interaction influences the individuals' construction of the knowledge. This approach asserts that that learning takes place through interactions with others in social settings such peers and teachers. This type of constructivism traces ideas back to Vygotsky. He emphasized the critical importance of culture and the importance of the social interaction for cognitive development. For Vygotsky, learning and development is a social and collaborative activity. Vygotsky's ideas have acted base for also contexual constructivism and social constructionism. Unlike Piaget, he suggested that learning precedes development (Vygotsky, 1963). According to Vygotsky, intellectual development is influenced by cultural tools such as culture's language, social 
institutions, writing system, or counting system. Vygotsky thought that individual uses these tools in social interaction and integration of social factors with personal factors produced learning. After individuals shared their knowledge, they internalize the knowledge as personal knowledge. That is, development first occurs in social level and then in individual level. Vygotsky (1978) states: "Every function in the child's cultural development appears twice: first, on the social level, and later, on the individual level; first, between people (interpsychological) and then inside the child (intrapsychological)." (p.57). In addition, one Vygotskian notion that emphasizes social interaction is that of the zone of proximal development. Zone of proximal development is the difference what an individual can do alone and cannot do alone but can do with help. According to Vygotsky, learning occurs when learners are working in their zone of proximal development. If learners provided easy tasks they can do individually or difficult tasks they cannot do independently, little or no learning occurs. However, he proposed that if learners try to accomplish tasks with the help of guidance provided by more component peers or adults, they can easily complete the task and build their own knowledge. Therefore, Vygotsky's theory supports the use of cooperative learning strategies in which students work together and help each other about the problems (Driscoll, 2005; Vygotsky, 1963; 1978).

Contextual constructivism, advocated by Cobern (1993), put more emphasis on the role of culture on the development of individual's ideas rather than social interaction. According to this view, learning takes places in a cultural context created by race, ethnicity, religion, language, economic and education levels, and geographic location. Cobern (1993) stated that an individual constructs knowledge so that it is meaningful in his/her life. Social constructionism has its roots in the work of Gergen (1985). From this constructivist view, knowledge cannot be individual or universal. Language plays an important role in construction of knowledge and meaning-making process. Meanings of words are context dependent and they are achieved 
through social interdependence. Briefly, knowledge resides within societies (Geelan, 1997). Critical constructivism considers learning within a social and cultural environment, but emphasizes an additional critical dimension with the focus on the importance of cultural myths which counteract constructivist environments. According to this type of constructivism, social reconstruction is important in order to reform the social structures of the community according to constructivist approach (Geelan, 1997).

Given the characteristics of constructivism, we should examine how teachers instruct their students considering constructivist principles. Since active construction of knowledge is the main idea, constructivist teaching puts emphasis on activating students' existing structures. Utilizing student-centered instructional strategies instead of teacher-centered ones, constructivist teachers facilitate students' thinking process so that they construct their own knowledge through activities. From constructivist view, learner's previous knowledge, beliefs and attitudes are important in the process of knowledge construction. Therefore, during constructivist teaching, embedding learning in challenging and authentic context make learning relevant to students and encourage them to use their existing knowledge. In addition, providing multiple representation of reality (e.g. visual, auditory, or tactile) facilitate students learning. As social negotiation and interaction is also one of the important features in constructivist learning environments, providing opportunities for students to communicate with other students and share their knowledge each other help them construct their own learning. For example, group work and group discussion support construction of knowledge through social interaction. In constructivist learning environment, teachers accept student autonomy and serve in the role of facilitators. They encourage questions and discussion among students by asking open-ended questions. In the perspective of students' role, students engage in minds-on activities and build their knowledge rather than receive or assimilate knowledge from teacher. In other words, students are 
the owner of their own learning (Driscoll, 2005; Gallagher, 1993; Glaserfeld, 1993; Jonassen, 1994; Tobin \& Tippins, 1993).

There are many instructional strategies that fall under constructivist teaching approach. In this study, one of these strategies called as case-based instruction is used based on the sociocultural constructivist perspective (Driscoll, 2005; Ertmer \& Dillon, 1998; Guest, 2007; Hmelo-Silver, 2004; Mayo, 2002; Sudzina, 1997). Case-based instruction provides students an active and social learning environment in which they examine authentic problems presented by cases in small groups.

\subsection{History of Case-based Instruction}

Case-based instruction was actually introduced in 1871 by the Harvard Law School and use of it has continued up to the today's law classes. Cases are real stories essentially composed of criminal and civil event. Cases are from the past and students use them as examples of judicial reasoning in their profession. In class, students read the cases on their own, figure out the fundamental principles of law, and build decisions through discussion of the cases by a series of question. In other words, Socratic Method is common method of case teaching in law schools. The cases are closed-ended and have a correct answer (Barton, 2008; Herreid, 1994; 2007; Tomey, 2003). In the 1940s, James Conant, a chemistry professor at Harvard University, used historical cases in his science lessons. Cases were historical events such as discovery of oxygen and the overthrow of the phlogiston theory. In the class, the instructor was a storyteller and students were the audience. Conant presents a historical view of a number of the great scientists, their errors and brilliant insights, their methodological approach to solve the problems, the influence of social factors on the development of science, and discoveries popping up serendipitously in his books called "On Understanding Science" and "Harvard Case Histories in Experimental Science” published in 1947 and 1957, respectively (Herreid, 1994; 2007). 
After uses of cases in law schools, medical schools applied cases in their curriculum. Similar in law schools, cases were chosen from real stories and served to illustrate general principles and their applications. Again, there were predetermined correct answers for cases illustrating a particular health problem. In medical education, small groups of students and faculty members worked together on cases. Students worked with patients in clinical settings, collected data about their health problems, analyzed data and reached a solution of the particular problem. This is called as Problem-based learning pioneered by McMaster University in Canada in the late 1960s (Herreid, 2007; 2011). Today, this method has been used in many medical schools. Cases have also been used as a teaching tool in business schools. For the first time, Harvard business school professors introduced cases in their classes to provide students actual experience about use of learning in the real world. In these lessons, businessmen were invited to tell students about a real business problem. Then, students analyzed the data from the documents provided to them. After that, they held discussions and offered solutions. Today, business cases are continuing to be employed in classes. Instructors give a real case to students and have them determined the action that should be taken through small and class discussion. Similar in medicine, cases are incomplete and students are required to solve it. However, unlike medicine, business cases do not have a predetermined correct answer. The original case-based instruction was partially inspired from the business school case-based instruction (Herreid, 2007; Barton, 2008). In summary, cases are usually real stories used to teach students about their field, but they are not delivered in the same way. Some cases have a correct answer while others have multiple solutions based on the subject matter.

Case-based instruction is increasingly being used in other disciplines such as nursing (Kaddoura, 2011; Thomas et al., 2001), teacher education (Schulman, 1992), psychology (Mayo, 2002; 2004), educational psychology and measurement (Sudzina, 1997), instructional design (Ertmer \& Russell, 
1995), and physical education (Wright, 1996). Moreover, recently, case-based instruction has gained popularity in science education (Herreid, 2005).

\subsection{Case-based Instruction}

Case-based instruction was simply defined as using cases which are described as "stories with an educational message" (Herreid, 2007, p. xiv). In

other words, "Cases are well-written vignettes, usually expressed as dilemmas that allow the reader to engage ideas along emotional and intellectual dimensions" (Coppola, 1996, p.2). Cases help learners to understand the relevance of science in society (Herreid, 2007). In a broad sense, case-based instruction involves "learning by doing, the development of analytical and decision-making skills, the internalization of learning, learning how to grapple with messy real-life problems, the development of skills in oral communications, and often teamwork" (Herreid, 2007, p.30).

Stories have a long history of usage for instruction. For example, society's culture, values, and history were transferred by storytelling before the written language. In addition, legends, myths, fables and parables are the form of stories as instructional tools to convey important information. Today, storytelling is still using as information medium in education and training of all types such as dentistry, the military, general medicine, and business (Andrews, 2010; Andrews, Hull, \& Donahue, 2009). Although all stories include information, the aim of a story may vary from entertainment to instruction (Andrews et al., 2009). Regarding the philosophical shifts related to the nature of learning, Andrews et al. (2009) examine the storytelling instructions in the view of whether learners are active and learn in a context. Based on their analysis, they described four types storytelling instruction: case-based, narrative-based, scenario-based, and problem-based instruction. Although these methods involve stories, they differ from each other in terms of the purpose of the story and how it is delivered during the instruction. Andrews et al. (2009) described the characteristics of these methods as follows: 
Case-based instruction: The story has a historical nature and it involves a fixed problem and solution. During this instruction, the learners take place outside the story context and they discover the facts and events occurred in the story with analyzing their reasons.

Narrative-based instruction: The problem and solution are fixed and learner is put in the context of the story. Fictional or non-fictional narratives can be used in this instruction. Emotional engagement of the learner with the situation of the narrative is the main purpose of this instruction.

Scenario-based instruction: This instruction provides learners interactive, real experience by stating scenario including a problem with fixed solution criteria. Therefore, different outcomes are produced based on learners' decisions. Scenarios can be fictional or non-fictional. Scenarios are heavily used in operational training such as military. The main goals of scenario-based instruction are to measure specific performance outcomes and improve them.

Problem-based instruction: The problem given in the story is ill structured. That is, the problem does not have predetermined criteria and parameters that are needed to solve it. The problem can be fictional or non-fictional. In this instruction, learners solve the problem in a small collaborative team environment. The teacher takes on the role facilitator of the discussion. Each problem solving requires over several sessions.

Although Andrews et al. (2009) described the story used in the casebased instruction as historical story, it is not necessary. Case-based instruction can also provide a fictional or nonfictional problem to learners and team learning, which is similar in problem-based instruction. However, case-based instruction differs from problem-based instruction in term of their instructional process (Herreid, 2007). The characteristics of problem-based instruction defined by Savery (2006) are provided below. 
- Students must have the responsibility for their own learning.

- The problem simulations used in problem-based learning must be ill-structured and allow for free inquiry.

- Learning should be integrated from a wide range of disciplines or subjects.

- Collaboration is essential.

- What students learn during their self-directed learning must be applied back to the problem with reanalysis and resolution.

- A closing analysis of what has been learned from work with the problem and a discussion of what concepts and principles have been learned are essential.

- Self and peer assessment should be carried out at the completion of each problem and at the end of every curricular unit.

- The activities carried out in problem-based learning must be those valued in the real world.

- Student examinations must measure student progress towards the goals of problem-based learning (pp. 12-14).

Problem-based instruction and case-based instruction are very similar in terms of their characteristics. For example, both approaches are studentcentered and collaborative, provide an authentic context for learning, and involve discussion sessions. However, they differ from each other in many points. The main difference between these two approaches is that problembased instruction requires more course session to investigate each problem than case-based instruction. In case based instruction, each case is generally investigated in two course sessions. In addition, problem-based instruction must involve an ill-structured problem which is provided in a kind of case. However, in case-based instruction, the case is not necessarily a problem. In other words, a case can be a story including a learning message such as an article from a newspaper or an anecdote from history as well as problem. Traditionally, students read and reflect on case questions with teachers and 
peers by engaging in a discussion. The discussion is the important part of the learning. On the contrary, in problem-based instruction, students are provided a series of artifacts and they determine the problem and propose a solution by examining the documents. The learning is embedded in problem solving process. Students are expected to master the course objectives while working on the problem (Bridges \& Hallinger, 1992; Kain, 2003). Then, a discussion session similar to case-based instruction is followed. Moreover, case-based instruction has different types which are described in the next part. In casebased instruction, the learning environment can be individual as well as collaborative, which is the essential characteristic of problem-based instruction. In contrast to problem-based instruction, case-based instruction can be conducted with large groups by using clicker cases defined in the next part. Another difference is that problem-based learning offers students to explore the knowledge needed to understand a given phenomenon whereas CBL requires the students to have a degree of prior subject matter knowledge to solve the problem given in the case (Allchin, 2010; Bridges \& Hallinger, 1992; Williams, 2005; Tarnvik, 2007).

Case-based instruction has also commonalities with context-based instruction since both of them provide learning in a context. Context-based instruction is defined as "using concepts and process skills in real-world contexts that are relevant to students" (Glynn \& Koballa, 2005, p. 75). As in the case-based instruction, students learn subjects in a real-world context that allows them to make connections between the subjects and their lives. In context-based instruction, a series of case studies that are based on a real-world context was developed and related to the concepts of the chemistry curriculum (Hofstein \& Kesner, 2006). Pilot and Bulte (2006) stated that "contexts are meant to explicitly relate the sciences and technology to socio-scientific issues" (p. 1088). For example, by utilizing context-based instruction, organic chemistry may be introduced in the context of materials such as plastics and polymers that are familiar to the readers. Another example is that 
environmental context such as acid rain may be used to teach the concepts of acids, bases, and pH (Schwartz, 2006). Similar to case-based instruction, context-based instruction allow students to see "the importance and relevance of science for themselves and the application of scientific concepts and methods" (Parchman \& Luecken, 2010, p. 2). However, in context-based instruction, a unit is taught through cases based on a particular context, which generally describes a societal problem in the real world whereas a unit can be taught by forming cases based on different contexts and cases do not have to involve a problem in case based instruction.

\subsubsection{Types of Cases}

The case-based instruction is extraordinarily flexible as a teaching method. There are two basic questions while using this method. The first is, how will the cases be written? The second is, how will the cases be taught? (Herreid, 1994).

A case can be written differently for different teaching formats depending on the purpose of the course. Reynolds (1980) categorized cases into three main types: decision or dilemma cases, appraisal cases, and case histories. The first one is typically written as dilemmas in which there are decisions that the characters of the story needs to made. In appraisal cases, readers are provided a situation via story and then, they analyze the situation and try to answer the process going on the situation. The last type of case is largely finished stories serving as illustrative models of science.

While writing a case, a case writer should consider (a) characteristics of a good case and (b) process of a case writing.

a. Characteristics of a good case:

Although literature provided different features to look for while choosing a good case or to look out for while writing it, there are common characteristics that a good case should have. To adapt these characteristics into the cases, the writer can be used many ways from the characters of the case to 
the presentation of the problem. For instance, a good case should be engaging (Herreid, 1997; Kim, Phillips, Pinsky, Brock, Phillips and Keary, 2006; Wasserman, 1994). It should draw readers immediately into the story. For this aim, characters of the case should create empathy to make story more engaging and to put the student into situation of the characters that faced the issue (Herreid, 1997; Wasserman, 1994). Writer should give the characters' personalities so the reasers will be able to think through the issue in a way similar to the characters that are the decision maker (Herreid, 1997). In addition, it should involve interesting and relevant pieces of information for engagement of the reader in making a decision throughout the case (Kim et al, 2006). Another main characteristic of a good case is the relevance of it to the reader (Herreid, 1997; Kim et al, 2006). It should involve situations from readers' lives. In other words, reader should know the situation or they are likely to face it in their future lives. This makes the case something worthy for studying (Hereid, 1997). Relevance of the cases increases learners' interest and motivation. For this aim, cases should be appropriate to the level of learner in terms of backgrounds, needs and diversity of learners (Kim et al., 2006). Realism is also one of the key features of a good case. That is, case narratives must be believable (Wasserman, 1994) Realism increases the likelihood that learners will transfer their learning into other settings. In order for cases to be realistic they should provide authentic materials, distracters, and gradual disclosure of content (Kim et al., 2006). In addition, the case must tackle a current problem in order to that students feel the problem is important to solve it. The case on current issues will awaken the students' interest before one on the past issues. If the problem is very popular in the media, it will increase the power of the case and thus readers grow to care (Herreid, 1997). Finally, a good case should be challenge. It should include a something controversial issue or dilemma requiring a decision to be made. Moreover, it should force the readers to discuss and solve it (Herreid, 1997; Wasserman, 1994).

b. Process of a case writing: 
Wasserman (1994) defined the process in a case writing as choosing big ideas related to the course content, deciding the story and its characters, building up a dilemma, creating study questions, getting feedback from colleagues, and revising the case. Similarly, Herreid (1999) set several steps to write a case. First, the writer decides on a topic that will be taught. Then, s/he identifies the content of the case by reviewing and researching the topic. After that, the characters are decided and story is written. While writing the story, terms or concepts related to the topic are introduced. After having a draft, the writer is going through the case again and listing the major and minor topics that are likely to come up in a discussion of the case. Finally, a reasonable version of the case is formed and discussion questions are included at the end of the case.

Instead of writing the cases, pre-existing materials such as articles, newspapers, magazines, advertisements, videos, and television dramas can be used as case materials. These materials are familiar sources for students and they are cheap and easy to find. In addition, these cases reflect authentic parts of the student's life. While choosing a case, teachers should consider its appropriateness for objectives of the course, quality of narrative, readability, its potential for stirring student interest to the content and its ability to provoke discussion about the dilemma (Wassermann, 1994).

So far, I have clarified how to write a good case considering some characteristics. Now, I will focus on how to teach those cases. Stories are common element of case-based approach and instructors are free while presenting them in this approach (Herreid, 2011). In the literature, there are different types of case-based instructions which differ in the way the instructor delivers the story in the classroom (Cliff \& Wright, 1996; Herreid, 1994; 1998; 2011). In 1994, Herreid presented eight different formats on how to teach using cases: lectures, discussions, debates, public hearings, trials, problem based learning, scientific research team, and team learning. Four years later, Herreid (1998) revised his classification scheme realizing that he underestimated the 
number of extant approach. He classified the types of case teaching methods under four major headings covering the previous formats of case studies: individual assignment (e.g., directed case study), lecture (e.g., storytelling), discussion (e.g., trial and public hearing), and small group activities (e.g., team learning, problem-based learning). In a recent study, Herreid (2011) enlarged his categorization by adding new types of case teaching methods. The new classification and descriptions is as follows.

The lecture format of case-based instruction was introduced by James Conant in the 1940s (Herreid, 1994). In this method, the role of the instructor is storyteller. On the contrary, students' role is to listen to case and take notes if needed. An important aspect of this method is that the information is presented in the context, which helps students relate their learning with their life.

Although this method provide more engaging environment than traditional lecturing method, students are still passive in learning process.

Another format of teaching cases is the discussion method widely used in business and law schools. It is the best known method to deal with cases. Students are usually presented with decision or appraisal cases. In this method, instructors ask probing questions, students analyze the problem illustrated in the case, and then whole classroom discussion session was started by the help of the instructor. The format of whole classroom discussion may be different by inclusion of debates, symposia, trials, and public hearing. Class size is important for this method. When class size is too small there is not enough diversity of opinion. When it is too large only a few students are engaged in a discussion while the rest of the class is passive (Herreid, 1994).

In small-group method, collaborative or cooperative learning strategies are used with small groups. There are four formats for small-group case-based instruction: problem based learning, interrupted case method, intimate debate method, and team learning. Problem based learning widely used in training medicine students is the most popular small-group case approach. Teams of medical students worked with tutors. In addition, information is provided over 
several class periods and students do literature research if it is needed. Another common variation of small-group methods is the interrupted case method. Unlike problem-based learning, students deal with each case in a single class period without literature research. Cases provide all information and data that students use while solving the problem. The intimate debate method is effective in dealing with controversial topics such as global warming or stem cell research. Groups of students prepare both pro and con sides of an issue. Then, pairs of students in the groups couple with pairs of students in another groups having opposite view on the question or issue and argue from their viewpoints. Then, student pairs reverse the roles. Finally, they try to reach a consensus on the question. Last form of small-group method, team learning, was offered by Larry Michaelsen (1992). In this format, before the class session, students are given a reading assignment. In the class session, students first take an individual test related to the reading material and then, they take the test in small groups. Both individual and group test are scored in the classroom immediately.

Cases can be worked by individuals as well as groups, which are called as individual cases. One type of using individual cases is the dialogue case method. In this method, students are asked to write a dialogue between two people holding opposite views on a controversial topic. The students are required to reference all claims that their characters make. At the end of the dialogue, the students should state their own side on the topic with their reasons. Another type of using individual cases is the direct case method in which the case is given to whole class but students work individually. The case involves a small scenario and a few following questions having a single and correct answer. This type of case is appropriate in anatomy and physiology classes since the emphasis of the case is factual information. After students respond to the questions individually and the instructor give the lecture on the topic, a classroom discussion based on students responses is run by the instructor. 
Cases are also taught in a computer-based interactive environment. This method is called as computer simulation cases developed to enhance learning genetics and infectious disease by Bergland and others (2006). In this method, firstly, students view a video and gather background information about a problem. Then, they apply their knowledge into practical settings by the help of simulations in order to solve the problem. After getting the results, students prepare interactive web page posters reporting results of their investigation.

The last method for teaching cases is clicker cases. This method provides an application of cases in huge classes especially in auditoriums at universities due to fact that running a classroom discussion or forming smallgroup conversations is difficult in these settings. In this method, instructors ask students a multiple-choice question in the case format on a PowerPoint slide and students respond by using a radio frequency clicker like remote control. Then, the classroom computers display the students' responses on a screen.

Although there are more ways to teach cases, instructors should choose the best appropriate one for their class and they should be aware of potentials of types of case-based instruction for learning (Herreid, 2011). Based on Dale's (1969) Cone of Learning model ranking the instructional methods in terms of their effects on retention of learning, Herreid (2011) matched the various case methods with learners' retention of information. Figure 1 shows matching between Dale's Cone of Learning model and case methods. Herreid have placed small-group cases in the position of greatest type of case method to enhance learning since this method provides more amount of interaction between participants and more opportunities students to teach other students when compared to other types of case studies methods. 


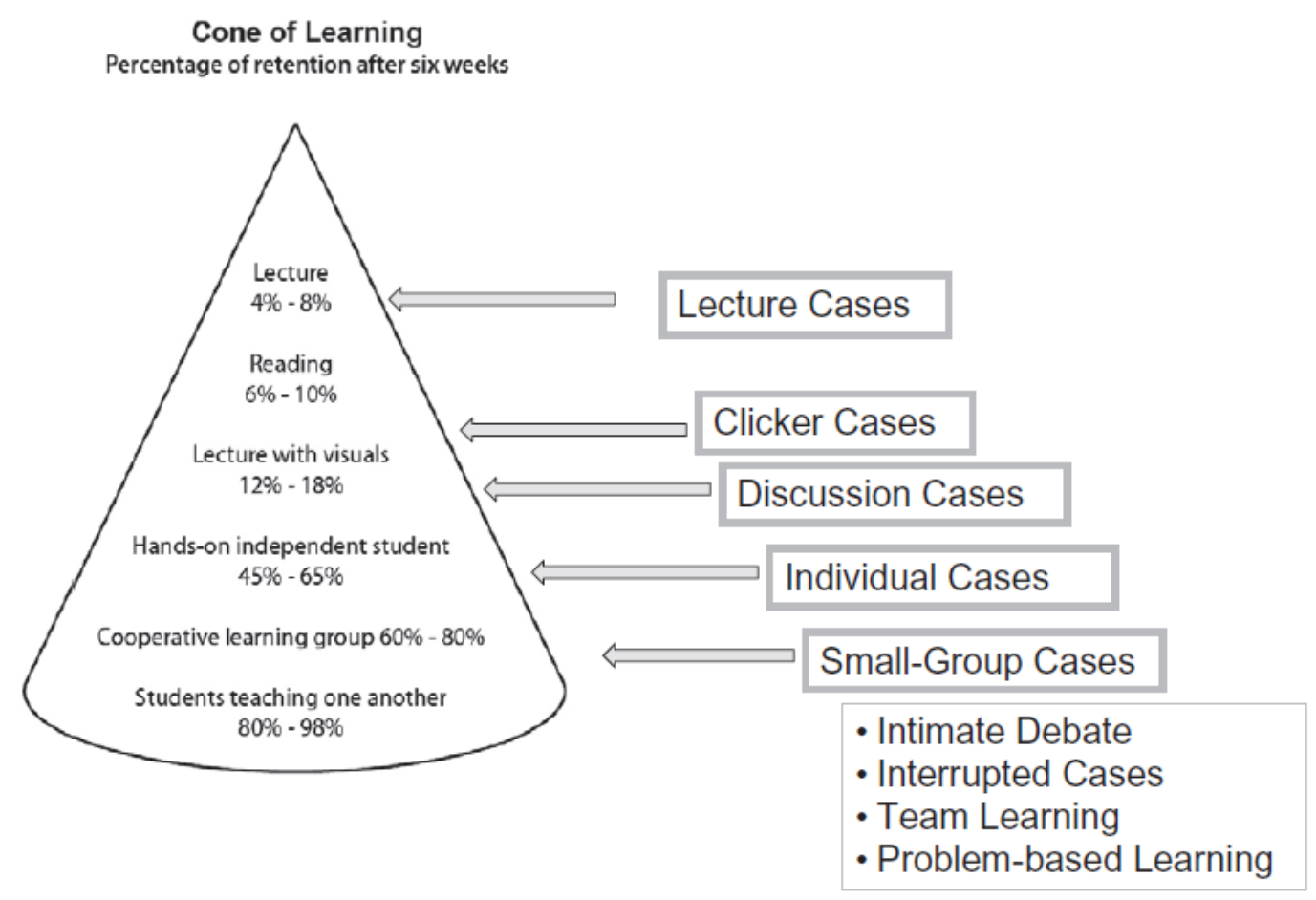

Figure 1 Cone of Learning and Case Methods (Herreid, 2011, p. 36).

Wasserman (1994) also described basic principles of the case-based instruction which are cases, study questions, small group work, debriefing a case, and follow up activities. This kind of instruction looks like combination of discussion method, direct case method explained under individual cases, and small group method stated by Herreid (2011). According to Wasserman, as in the direct case method, written cases are directly given the students. In addition, at the end of the each case students are asked a list of study questions to examine concepts and issues related to the case. Unlike from direct case method, students work as groups. In terms of working as groups, this kind of instruction is similar to small group method stated by Herreid (2011). Small group works may occur during class time or take place outside-of class as an assignment. After each group respond to the study questions, whole class debriefing is occurred as in the discussion method and direct case method. 
During the debriefing time, teachers lead a discussion by asking questions in order to enable students analyze the case deeply to make their own meanings and find their own solutions. Different from the characteristics of case-based instruction stated by Herreid (2011), Wasserman (1994) highlighted follow-up activities during a case-based instruction. According to her, after debriefing a case, students may need to know more or want to find more data because discussion has increased ambiguities and students' interest. Therefore, teachers carry out follow-up activities from textbooks, articles from newspapers and magazines, tables, charts, research reports, other visual and written materials. Follow-up activities can be performed individually or in groups.

In addition to studies described what should do for a great case teaching, Herreid (2007) emphasized some important issues related to casebased teaching by focusing on what not to do when teaching cases. He emphasizes the need of adequate preparation for case based instruction by saying teachers: don't fail to prepare the objectives for using the case, the right questions that will be asked, and to plan a way to connect the major issues together. As another issue, he pointed out starting discussion with a closeended question is not effective since there is one answer. Therefore, these kinds of question don't get students to talk. Herreid warns teachers not to forget to use of blackboard in an organized way since it helps students to understand what is going on during the instruction and to take notes for their future studies. For a great discussion, teachers have to make the classroom safe for students' conversations and students have to know each other. During the discussion, teachers don't forget to get every student into discussion in order to get different ideas and facilitate discussion. In addition, teachers don't forget to listen to students' ideas and connect these ideas with another in order to keep students in conversation and lead the discussion effectively. For a good casebased instruction, seats are not leaved in a row since this arrangement does not permit all of the students to see one another. In a traditional setting arrangement, having a good conversation could not be expected during the 
instruction, especially discussion. In addition, this setting arrangement does not allow more spaces to teachers to move around the classroom in order to follow students' works and guide them effectively. Regarding discussion period, teachers don't expect to have a great discussion in a 50-minute period. This period is not enough for students to settle down, focus on case and discuss the questions. At least 90 minutes is suggested to get into a subject deeply.

In summary, cases could be taught in different ways such as whole class and small groups. The teaching methods for cases are mostly depended on the size of the class and time. However, when appropriate conditions are exist, small group format is the best strategy for learning among other alternative formats as stated by Herreid (2011). In this format, students can learn more from each other due to nature of team learning strategies. Hence, in the current study, case-based instruction is carried out in small group format.

\subsubsection{Advantages of Case-Based Instruction}

Case-based instruction encouraged students to go beyond rote memorization to an understanding of process (Cornely, 1998). Moreover, casebased instruction helps learners to recognize why they are learning science, and when and how to use their learning since this instruction promote learning in a variety context, which is the emphasis of science education. In other words, case-based instruction helps learners to put the theoretical knowledge into practice by promoting them to encounter real life situations or authentic activities (Guest, 2007; Herreid, 1994). Thus, learning subjects taught in the class are seen as an important, interesting, and useful by the students (Ayyildiz \& Tarhan, 2012; Mayo, 2002), which enhance their scientific literacy and also increase their attendance to the courses. By recognizing the relevance of science to their life and society, students can have a more positive attitude about science, understand how science works, and critically appraise scientific events they hear from media (Herreid, 2005). Regarding the attendance, 
Herreid (1994) noted that the course had $95 \%$ attendance when cases were used while traditional lecture courses had 50-65\% attendance.

Research studies also noted that case-based instruction provides benefits for developing students' higher-order skills which science teachers strive for. Herreid (1994) noted, "Although the case study method cannot cure all of the ills in the teaching of science, it is nevertheless ideal for the development of higher-order reasoning skills, which every science teacher claims they strive to instill in their students." (p. 228). For example, students' problem solving, reasoning, critical thinking and decision making skills were enhanced when they actively engaged in dissection and analyses of real-world dilemmas and take responsibility for their learning (Herreid, 1994; Knight et al., 2008; Lantz \& Walczak, 1997). In addition to higher-order skills, by the help of active engagement of students and small group work case-based instruction can increase students' self-efficacy since it provides mastery and vicarious experience for their learning (Thomas, et al., 2001). In fact, Mayo (2002) found that most students reported having a greater sense of confidence after engaging case-based instruction. Finally, this kind of learning environment is effective in honing students' collaboration and communication skills (Herreid, 1994; Lantz \& Walczak, 1997).

\subsubsection{Disadvantages of Case- Based Instruction}

The main disadvantage of the case-based instruction is that its inefficiency in term of content coverage. When compared to traditional instruction, the amount of the topics or information that will be covered is smaller in case-based instruction since it requires more time (Herreid, 1994, 2005; Hutchinson, 2000). However, teacher educators think that the benefits provided by case-based instruction outweigh the loss of content (Hutchinson, 2000; Lantz \& Walczak, 1997). In addition, when it is considered the process of writing or selecting cases, it is understood that designing and developing cases take considerable time. 
Any instructional strategy, even case-based instruction, can result in ineffective learning when it is used incorrectly. In case-based instruction, it is important to stimulate students to solve problems and take responsibility for problem solving (Savery \& Duffy, 1995). Participation into discussion session of case-based instruction and its quality greatly affect learning. Students must come to class and contribute discussions. During discussion, students may be reluctant to speak out and a few of them may contribute. Therefore, teachers should be good at leading discussions.

There is not a perfect instructional strategy that is appropriate for every student even when it is well executed. Therefore, case-based instruction is not the best method and learner characteristics are important for the success of case-based instruction. For example, case-based instruction is not effective for students who have poor self-regulatory skills (Ertmer \& Newby, 1996). Therefore, instructors should pay more attention to give support those learners. In addition, Cossom (as cited in Ertmer \& Dillon, 1998) stated that case-based instruction could not meet all students' learning needs well. Nonexistence of accurate answers and absence of clear decision about a particular case could be seen as frustrating by some students. Students are used to be taught by lecturing method and they know how to deal with it. Those students might not be willing to try new teaching methods and they might oppose change in the way they are taught (Herreid, 2005). Therefore, teachers must be aware of students' ideas about case-based instruction and provide support for unprepared or reluctant learners.

\subsection{Attitude toward Science}

Attitude is defined as positive or negative feelings or predisposition held by individuals towards something such as ideas, issues and objects or someone (Koballa \& Glynn, 2007; Simpson, Koballa, Oliver, \& Crawley, 1994). For example, expressions such as "I love science," "I hate chemistry," or "Chemistry learning is enjoyable" reflects general positive or negative 
feelings about something thus attitude. Promotion of favorable attitudes toward science and science learning is one of the main concerns of science education as well as meaningful learning. Science and technology are integral parts of our lives. Therefore, regardless of one's profession, attitudes toward science affect individuals' decisions and behaviors. The future of societies will be determined by citizens since their thought about and attitudes toward scientific discoveries, issues and technological innovations will shape their society. For example, people's appreciation of science may provide positive influence on their behavior regarding global warming (Movahedzadeh, 2011). Hence, preparation of citizens to have positive attitudes toward science is important. Moreover, it is widely accepted that students' attitudes in science influence their selection of science related courses, their science learning, and their choice of future career (Nieswandt, 2007; Oliver-Hoyo \& Allen, 2005; Osborne, Simon, \& Collins, 2003; Woolnough \& Guo, 1997). Although some studies found no relationship between students' attitude toward science and their science learning (Nieswandt, 2007; Thompson \& Soyibo, 2002), most research studies indicated that attitude toward science is positively related to science achievement (Papanastasiou \& Zembylas, 2002; Freedman, 1997; Salta \& Tzougraki, 2004; Weingburgh, 1995; Oliver \& Simpson, 1988; Simpson \& Oliver, 1990). Regarding chemistry learning, result of the study of $\mathrm{Xu}$, Villafane and Lewis (2013) showed that students' achievement in chemistry could be improved by fostering students' positive attitude toward chemistry. In fact, Kan and Akbas (2006) found attitudes toward chemistry as a significant predictor of chemistry achievement.

Given the importance of attitudes toward science in science learning and the future of society, science educators have examined the factors affecting students' attitude toward science. One of the factors, learning environment, appears to have an important influence on students' attitude toward science (Wong, Young, \& Fraser, 1997). A learning environment in which students perceived importance of science fostered positive attitude toward science 
(Papanastasiou \& Zembylas, 2002). Moreover, regarding learning environment, nature of instruction has a significant impact on attitudes toward science (Aydeniz \& Kaya, 2012; Freedman, 1997; Adesoji \& Raimi, 2004; Gibson \& Chase, 2002; Wong, et al., 1997; Osborne, et al., 2003). Main characteristic of effective instructions on promotion of positive attitude toward science is active participation of students in learning process (Oliver-Hoyo \& Allen, 2005; Wong, et al., 1997). Greater open-endedness in chemistry class was linked strongly with enjoyment of the chemistry lessons (Wong, et al., 1997). Moreover, Fouts and Myers (1992) found that the more students are actively involved in and take responsibility for learning, the more they were likely positive attitudes toward science. Gibson and Chase (2002) stated that students taught by inquiry-based approach had more positive attitudes towards science when compared to students taught by a traditional approach. Their results revealed that students like "hands-on science activities that are relevant to their lives, the chance to discuss issues, and the time to explore issues in depth" (p. 702). Similarly, Freedman (1997) argued that "Instruction that makes science more exciting and encourages students (e.g., laboratory) has a positive influence on students' attitude toward science.” (p.344). These findings are also supported by the study of Aydeniz and Kaya (2012) which found that students were interested in hands-on science learning and wanted to learn science through laboratory based science activities. Considering laboratory instruction, the study of Adesoji and Raimi (2004) revealed that enhance laboratory instruction including problem solving technique had more significant effect on promoting positive attitude toward chemistry when compared to conventional laboratory instruction. In addition, argument-driven inquiry laboratory instruction which provides opportunities for students to engage in scientifically oriented questions, work collaboratively, and discuss on findings, concepts, and ideas enhances positive attitudes toward chemistry when compared to traditional laboratory instruction (Walker, Sompson, Grooms, Anderson, \& Zimmerman, 2012). Moreover, chemistry lessons 
enriched by virtual laboratory experiments make a more positive impact on students' attitude toward chemistry than traditional chemistry lessons (Tuysuz, 2010).

Cooperative learning method is also found as effective in enhancing attitude toward science. Research studies indicated that learning science through group interaction developed more positive attitude about science (Kose, Sahin, Ergun, \& Gezer, 2010; Altinok \& Un-Acikgoz, 2006; Shibley \& Zimmaro, 2002). Thompson and Soyibo (2002) pointed out the positive impact of practical work in small groups on students' attitude toward chemistry. In the study, they investigated the effect of the instruction which was combination of lecture method, teacher demonstrations, class discussion and activity-based practical work in small groups with the comparison of the instruction not include practical work. The results of the study indicated that students performed practical work in small groups demonstrated more positive attitude toward chemistry than their counterparts who were not exposed practical work. In conclusion, synergistic effect of activity-based and cooperative learning environment encouraged students' attitude toward chemistry. In another study conducted by Oliver-Hoyo and Allen (2005), the synergistic effect of realworld applications, hands-on activities, cooperative learning, and engaging technology on students' attitudes toward chemistry learning was found more efficient over traditional instruction.

Movahedzadeh (2011) stated that "making the learning and the teaching of the topics more relevant to students' lives helps them see the value of science and in turn motivation them to develop a better attitude toward science and science education" (p. 15). Similarly, according to Raved and Assaraf (2011), one of the factors influencing students' attitudes toward science is the relevance and authenticity of the topics studied. Considering the characteristics of effective instruction on students' attitude toward science or domains of science, case-based instruction may helpful in order to promote positive students' attitudes toward science. Case-based instruction provides 
opportunities for students to participate actively in learning process, work on hands-on activities, study in small groups, deal with real-life events, and discuss on findings (Guest, 2007; Herreid, 2005). Although research studies indicated that students found case-based instruction as enjoyable, interesting and encouraging for learning (Ayyildiz \&Tarhan, 2012; Bridges \& Hallinger, 1999; Dori \& Herscovitz, 1999; Herreid, 2006; Jones, 1997; Mayo, 2002; 2004; Naumes \& Naumes, 2006) there are few empirical evidence regarding the effectiveness of it on high school students' attitudes toward science, particularly chemistry (e.g., Cam, 2009; Yalcinkaya, 2010).

\subsection{Motivation}

The field of motivation has a long history in the literature. The broad and rich history hosts various theoretical approaches to motivation. In other words, many definitions of motivation have been proposed based on different approaches. Historically, there are four general approaches to motivation; behavioral, humanistic, cognitive, and sociocultural (Koballa \& Glynn, 2007; Woolfolk, 2005). Behavioral theories define motivation as "a change in the rate, frequency of occurrence, or form of behavior (response) as a function of environmental events and stimuli” (Pintrich \& Schunk, 2002, p.20).

Behaviorists claim that the frequency of a behavior bases on whether the person has been rewarded or punished for that behavior in the past. If a person' behavior is reinforced, s/he is more likely to behave in that way in the future. On the other hand, if his/her behavior is punished, that behavior is less likely to be occurred. In contrast, cognitive theories emphasize on the importance role of mental structures while deciding to perform a behavior. From humanistic perspective, motivation refers to “encourage people's inner resources-their sense of competence, self-esteem, autonomy, and self-actualization" (Woolkfolk, 2004, p. 343).Unlike behavioristic approach, humanist theories emphasize on individuals' awareness of themselves and their situation rather than their responses to external stimuli. Cognitive theorists conceptualize 
motivation as a process, rather than a product. The occurrence of the behavior is simply not due to the reinforcement or punishment. It is related to the person's beliefs, thoughts, and emotions. From the cognitive perspective, motivation is functions of one's cognitions about the needs for doing the task, the consequences of the task completion, and about one's ability to do the task (Driscoll, 2005). Finally, sociocultural approach to motivation considers motivation to be social in nature and focus on participation, identities, and interpersonal relations in community. According to this approach, people engage in activities to keep their identities and their social relationships within the community (Woolfolk, 2005). Although all these approaches views motivation differently, each contributes to comprehensive understanding of human motivation. In light of the literature, Murphy and Alexandar (2000) identified four fundamental terms being examined by researchers in the field of motivation: intrinsic and extrinsic motivation, goal orientation, interest, and self-schema. Intrinsic motivation means that "motivation to do something for its own stake" (Pintrich \& Schunk, 2002, p. 245). In other words, individuals who are intrinsically motivated perform tasks due to their own desire, interest, and curiosity. Their performance does not depend on an external reinforcements or punishments. In contrasts, extrinsic motivation refers to "motivation to engage in an activity as a means to an end" (Pintrich \& Schunk, 2002, p. 245). Extrinsically motivated people work on a task to get a reward or to avoid from a punishment. Goal orientation can be defined as the reasons and purposes for engaging in a task. In addition, it reflects the standards that individuals use to evaluate their task performance. There are different goal orientations, but two of them that commonly identified by the researchers: learning and performance goals. A learning goal refers a one's focus on learning and mastering the task for his or her self-improvement, deep understanding, and development of skills. On the contrary, performance goal represents a one's focus on being superior, best, and winner in order to demonstrate his/her competence or ability to others (Ames, 1992; Dweck \& 
Leggett, 1988). Regarding interest construct, there are two kinds of interest: personal and situational. Personal interest is considered as a personality trait which is relatively stable and enduring aspects characteristics of the person such as interest in sports, science, or music. Situational interest is temporary and stimulated by contextual features of the activity, text or materials. In other words, it is being interested in the activity or task (Hidi, Renninger, \& Krapp, 2004). Last key term related to motivation, self-schema, reflects the person's conceptions about oneself such as self-efficacy, self-determination, and selfworth. Self-efficacy is defined as "people's judgments of their capabilities to organize and execute courses of action required to attain designated types of performances" (Bandura, 1986, p. 391). Rather than dealing with all the different motivational components, this study focuses on two of them: intrinsic motivation and self-efficacy.

\subsubsection{Intrinsic Motivation}

As mentioned previously, intrinsic motivation exists within the individual. It refers to engage in an activity that is driven by internal rewards rather than external outcomes. It is the internal self-determination of students, generated by the student. Intrinsically motivated individuals do a task to satisfy their curiosity or to feel enjoyment (Pintrich \& Schunk, 2002). Ryan and Deci (2000) stated that intrinsically motivated individuals perform on a task for "satisfaction of innate psychological needs" (p.57). Intrinsic motivation is interrelated with interest and relevance. That is, it derives from arousal, interest, and curiosity (Koballa \& Glynn, 2007). Therefore, if students find the task enjoyable, interesting, or valuable for their self-improvement, they will be more likely to engage in the task. Moreover, activities that hold appeal of novelty, challenge, or aesthetic value for an individual create intrinsic motivation. In educational context, a student participating in a learning task or pursing a particiualar goal because it is interesting, enjoyable, fulfilling, or meaningful is defined as intrinsically motivated. In other words, students are 
likely to be intrinsically motivated if they are interested in accomplishing the learning task, not just in getting good grades. Therefore, the task characteristics are critical in intrinsic motivation. As the intrinsic motivation exists within individuals, students are intrinsically motivated for some activities and not others, and not everyone is intrinsically motivated for any particular task (Ryan \& Deci, 2000). Intrinsic motivation is considered as central to how deeply and how well students learn (Shumow \& Schmidt, 2013). It results in high quality learning and creativity. It is also an important factor in cognitive, social, and physical development (Ryan \& Deci, 2000). Students who are intrinsically motivated are more likely to engage in the task willingly as well as work to improve their skills, which will increase their capabilities.

\subsubsection{Self-efficacy}

Self-efficacy is individuals' beliefs about their ability to organize and perform actions successfully (Bandura, 1986; 1997). Self-efficacy has vital effects on motivation, well-being and achievement due to the fact that if the individual believes that the result of the performance will be useful or positive, s/he will show enthusiasm to act it (Pajares, 2002). Self-efficacy is assumed to be task specific or domain specific (Bandura, 1997). For example, an individual might have high self-efficacy for mathematics activities, but a lower self-efficacy for science activities. Self-efficacy is grounded in Social Cognitive Theory which is a larger theoretical framework asserted by Albert Bandura (1977). Social Cognitive Theory discusses the human behavior within the framework of "triadic reciprocality" or reciprocal interactions among environmental factors (teacher, parents, peer feedback etc.), personal factors (cognitive, affective, and biological events) and behavior (performance) (Bandura, 1977; 1997). Bandura (1986) stated:

People are neither driven by inner forces nor automatically shaped and controlled by external stimuli. Rather, human functioning is explained in terms of a model of triadic reciprocality in which behavior, cognitive 
and other personal factors and environmental events all operate as interacting determinants of each other (p.18).

Bandura (1986) did not imply that directions and influence of the factors are always the same in strength. In other words, interactions among the three factors differ from person to person and one of the three factors or one of the bi-directional interactions among the factors may dominate others. Examples should be examined to understand reciprocality in more detail. For instance, teachers say "OK. Look here!" at the beginning of the lesson to stop students talking among themselves and to start the lesson. This is an example of influence of environmental factors on behavior. In this example, teacher's saying is an environmental effect on students' looking which is the behavior. In turn, teachers ask questions after she teaches something. If the students give wrong answers to the question (behavior), teacher cannot present the new topic rather s/he reteaches the old one (environmental factor) (Pintrich \& Schunk, 2002). For example, people's ideas about us or about our performance have effects on our self-efficacy beliefs, which is an example of environmental factor. This factor may affect these students' self-efficacy negatively (personal factors). Finally, personal factors which are cognitive, affective and biological events affect people's behavior. For instance, students' self-efficacy influences their choice of task, task performance and persistence on task. If a student believes that s/he can achieve something, s/he does not cheat from existing homework or projects, on the contrary s/he tries to do his/her own work. For example, if a student's self-efficacy is high in science and math subjects (personal factors), s/he selects science field in high school and then selects a job such as medicine, engineering or science teaching (behavior). In turn, behaviors also have influences on personal factors. For example, students observe their progress when they work on something. If the progress is good or desired (behavior), it will increase the self-efficacy. If not, it affects the selfefficacy negatively (personal factor) (Schunk, 2000).

Personal factors such as affective variables or cognitive events also affect each other in addition to behavioral and environmental factors' effects 
on personal factors. For instance, if a student uses an effective learning strategy which provides acquisition of skills, it leads to student to feel more confident about learning. In turn, the student's self-efficacy has an influence on his/her selection of learning strategy (Gredler, 1992).

Sources of Self-efficacy

Bandura (1997) suggested four main sources of self-efficacy: mastery experiences, vicarious experiences, social (verbal) persuasion, physiological and emotional states. Mastery experiences is one' own performance experiences in dealing with a particular task. Bandura considered mastery experiences as the most influential source of self-efficacy information. When people engage in tasks and activities, they interpret the results of their actions and use these interpretations to develop their self-efficacy. People feel capable or incapable of doing that task depending on their early experiences. If people interpret outcomes as successful, their self-efficacy beliefs increases and if they interpret as failures, their self-efficacy beliefs decreases (Bandura, 1997). Vicarious experiences, refers to people observations of others performances on desired behavior and estimations of their capabilities by comparing themselves with the models. Observing of the successful behavior of a model can raise observers' self-efficacy. However, poor performance of the model can decrease one's efficacy. It does not true that observing successful performance of all model increases one's efficacy and the inverse is also wrong. The power of the vicarious experience depends on the characteristics of the model such as competence, perceived similarity, credibility, and enthusiasm. For instance, if people see the models as very different from themselves, the models' behavior may not influence their self-efficacy. Vicarious experiences have weaker effects on self-efficacy than mastery experiences (Bandura, 1994; 1997). Social (verbal) persuasion refers to situations in which individuals are given feedback and judgments about their performance in a task from other people such as their peers, parents, and teachers. If a person gets positive affirmations about his/her capabilities to succeed in the task from others, that person will be 
encouraged to try hard to succeed, that is, his/her self-efficacy will be increased. However, similar to vicarious experience the impact of the positive feedback depends on the value of the persuader placed by the person (Bandura, 1997). Physiological and emotional states - such as fear, anxiety, and stress - in performing a task contribute to the one's development of self-efficacy beliefs. If a person has positive physiological reactions to an action, he/she will be more inclined to perform the action when compared to a person who has negative physiological reactions to that action (Bandura, 1997).

\subsubsection{Motivation to Learn}

Motivation is one of the crucial components of learning in any field of education. Glynn, Taasoobshirazi, and Brickman (2007) pointed out that motivation is "an internal state that arouses, directs, and sustains students' behavior" toward achieving learning goals (p. 1089). Motivational components affect students' engagement in learning tasks, effort and persistence in the tasks, strategy use, performance on the tasks thereby influencing their learning (Linnenbrink \& Pintrich, 2002; Ryan \& Deci, 2000; Pintrich \& Schunk, 2002; Walker, Greene, \& Mansell, 2006). Research studies indicated that student motivation to learn is one of the most important predictors of their academic achievement (Linnenbrink \& Pintrich, 2002; Zusho, Pintrich, \& Coppola, 2003; Walker et al., 2006). In the domain of science education, motivation to learn science positively related to science achievement (Glynn et al., 2007) Regarding the importance of motivation on students' learning, researchers attempt to explain what motivate students to learn, what drives some students to strive for particular learning goals, and why some students appropriate learning activities (Glynn \& Koballa, 2006; Zusho et al., 2003). According to Brophy (1988), motivation to learn is “a student's tendency to find academic activities meaningful and worthwhile and to try to derive the intended academic benefits from them” (pp. 205-206). Similarly, Linnenbrink and Pintrich (2002) stated that teachers can promote motivation to learn "by 
capitalizing on the utility of what is being learned (e.g., helping students see that the material is useful for things outside of school or future goals)" (p.319). Belief in the relevance and value of what students are learning to their personal goals including their future career affects motivation to learn which, in turn, influence academic achievement (Glynn, et al., 2007; Glynn \& Koballa, 2006; Vaino, Holbrook, \&Rannikmae, 2012). Therefore, educators advocated that motivation to learn and related outcomes were sensitive to characteristics of the learning context, including teachers' instructional practices (Ames, 1992; Glynn \& Koballa, 2006; Linnenbrink \& Pintrich, 2002; Pintrich \& Schunk, 2002). Science educators should attempt to arrange the learning environments toward to stimulate students' motivation considering students' intrinsic/extrinsic motivation, self-efficacy, interest values, and goals (Vaino et al., 2012; Pintrich, 2003). Researchers stressed the relevance of the topic to students' life and suggested that learning material should be meaningful and relevant to students' lives; therefore, students view the content they are learning as useful and learn the topic more meaningfully (Ames, 1992; Glynn, et al., 2007; Zusho, et al., 2003). Teacher can improve the meaningfulness of learning materials in the eyes of students "through the use of real-life examples and relating material to everyday applications, drawing cases from current newsworthy issues, giving local examples, relating theory to practice" (Vaino et al., 2012, p.411). In addition, providing interesting and enjoyable classroom activities such as exciting experiments enhances students' intrinsic motivation and (Linnenbrink \& Pintrich, 2002). In addition to relevance of the content to one's life, encouraging students' active participation in learning process through using small group work activities or leading discussions is useful for promoting motivation to learn (Glynn \& Koballa, 2006; Kusurkar, Croiset, \& Ten Cate, 2011; Vaino et al., 2012; Linnenbrink \& Pintrich, 2002; Ryan \& Deci, 2000). Establishing the learning environment as the kind of learning community and providing students to take responsibilities for their learning increase their sense of belongingness to a group, which enhance intrinsic 
motivation (Ryan \& Deci, 2000). Mastery experience such as working on classroom tasks might provide students with opportunities to be successful, thus facilitating their self-efficacy (Linnenbrink \& Pintrich, 2002). Students' beliefs about their performance capabilities in a particular domain affect their persistence and effort for completing learning task related to the domain, and thus academic performance (Bandura, 1997; Pajares, 1996; Pintrich \& Schunk, 2002). Self-efficacy has been positively related to achievement (Andrew, 1998; Zusho et al., 2003; Britner \& Pajares, 2006). In addition, feelings of competence greatly enhance intrinsic motivation. Students are likely to demonstrate limited motivation in circumstances where they lack confidence in their ability to succeed (Ryan \& Deci, 2000). Small group working may also serve as a vicarious experience, a source of self-efficacy. Collaboration provides students with opportunities to see how their peers approach the learning task and solve the problems. In other words, group working activities allow them to learn from peers. In addition, they get explicit feedback about their performance during the collaborative process (Dunlap, 2005; Sungur \& Tekkaya, 2006). Briefly, intrinsic motivation and self-efficacy could be enhanced in a learning environment in which students participate actively in the learning process, take responsibility for their own learning, and have opportunity to work on authentic, relevant, and meaningful learning tasks, and to collaborate each other. The scope of this study focuses on solely student motivation to learn chemistry.

Regarding the issues related to improvement of motivation to learn, Vaino et al. (2012) conducted a study to enhance students' intrinsic motivation for chemistry learning through the use of context-based learning modules in Estonia. They examined the differences in 416 high school students' intrinsic motivation measured before, after the first, and after multiple, use of modules by the help of Intrinsic Motivation Inventory. Based on the paired sample t-test statistics, results of the study indicated that students' motivation was significantly higher after they engaged in context-based learning modules 
compared to their previous chemistry lessons. It was concluded that contextbased modules including uses of authentic, everyday life scenarios, opportunities to collaborations among students, and involvement of students in learning process were effective in terms of stimulating students' intrinsic motivation. In a similar kind of learning environment, problem-based instruction, Dunlap (2005) found that undergraduate students' general perceived self-efficacy increased through the participation in an authentic activities and collaboration. Similar to context-based approach and problembased instruction, case-based instruction is seen as useful instructional strategy to make the learning more relevant and interesting in an active learning environment (Kusurkar, et al., 2011; Glynn et al., 2007). Cases are ideal tools to help students to see the connections between the concepts they are learning and real-world issues, which makes learning meaningful for them (Glynn et al., 2007; Mayo, 2004). In addition, small group work activities and discussions during the case-based instruction stimulate interaction of students' with each other and teacher and thus ensure students' active participation in the learning process (Yadav et al., 2007). Therefore, it is expected that case-based instruction promotes intrinsic motivation to learn and enhance self-efficacy. However, there are few studies that provide empirical evidence concerning the effectiveness of case-based instruction on students' motivation to learn chemistry (Yalcinkaya, 2010).

\subsection{Students' Understanding of Electrochemistry}

Electrochemistry is seen by students as one of the most difficult topic and they have many problems in understanding this topic in chemistry field (Thomson \& Soyibo, 2002). Several studies have identified students' conceptual understanding and difficulties in electrochemistry at high school and undergraduate level. Table 1 describes these studies in terms of sample size, grade level, and instruments used. 
Table 1 Studies in which students' understanding in electrochemistry was investigated

\begin{tabular}{|c|c|c|c|}
\hline Studies & Sample size & Grade level & Instruments used \\
\hline $\begin{array}{c}\text { Garnett and Treagust } \\
\text { (1992a) }\end{array}$ & 32 & Grade 10 & Interview \\
\hline $\begin{array}{l}\text { Garnett and Treagust } \\
\qquad(1992 b)\end{array}$ & 32 & Grade 10 & Interview \\
\hline $\begin{array}{c}\text { Ogude and Bradley } \\
\text { (1996) }\end{array}$ & $30+40$ & $\begin{array}{l}\text { High school and } \\
\text { Undergraduate }\end{array}$ & Questionnaire \\
\hline $\begin{array}{l}\text { Sanger and Greenbowe } \\
\text { (1997a) }\end{array}$ & 16 & Undergraduate & Interview \\
\hline $\begin{array}{c}\text { Sanger and Greenbowe } \\
\text { (1997a) }\end{array}$ & 16 & Undergraduate & Interview \\
\hline $\begin{array}{l}\text { Ozkaya, Uce, and Sahin } \\
\text { (2003) }\end{array}$ & 15 & Undergraduate & $\begin{array}{c}\text { Interview, Multiple } \\
\text { choice questions }\end{array}$ \\
\hline $\begin{array}{c}\text { Ceyhun and Karagolge } \\
\text { (2005) }\end{array}$ & 40 & Undergraduate & $\begin{array}{c}\text { Multiple choice } \\
\text { questions }\end{array}$ \\
\hline $\begin{array}{l}\text { Rahayu, Treagust, } \\
\text { Chandrasegaran, Kita, } \\
\text { and Ibnu (2011) }\end{array}$ & 433 & High school & $\begin{array}{l}\text { Multiple choice } \\
\text { questions }\end{array}$ \\
\hline $\begin{array}{l}\text { Loh, Subramaniam, and } \\
\text { Tan (2014) }\end{array}$ & 99 & Grade 10 & $\begin{array}{c}\text { Two-tier diagnostic } \\
\text { instrument }\end{array}$ \\
\hline
\end{tabular}

In the related studies, electrochemistry was divided into two topics as it is common in many textbooks: redox reactions (oxidation and reduction) and electrochemical cells (galvanic, concentration, electrolytic). In respect of redox reactions, research studies revealed some areas of students' difficulties: assigning oxidation numbers, identifying reactants as oxidizing or reducing agents, identifying reaction equation as oxidation-reduction equations, interdepence of oxidation and reduction reactions, and balancing redox 
equations. Garnett and Treagust (1992a) identified that students believe that oxidation numbers can be assigned to polyatomic molecules and /or polyatomic ions. In addition, students thought that oxidation state of an element is the same as the charge of the monatomic ion of that element. Students had also difficulties in terminology due to the linguistic complexity. They had difficulty in differentiating the terms of oxidant, reductant, oxidizing agent, and reducing agent (De Jong \& Treagust, 2002). Garnett and Treagust (1992a) reported that students believed that they could identify redox reactions based on changes in the charges of poly-atomic species in an equation. Moreover, their study indicated that student used definition of oxidation as the addition of oxygen and reduction as the removal of oxygen to identify oxidation and reduction. Furthermore, their study indicated that students thought that oxidation and reduction can occur independently.

Regarding to electrochemical cells topic, several areas of difficulties were identified in the literature: (1) identifying the anode and cathode of electrochemical cells, (2) understanding the need for a standard half cell, (3) understanding the current flow in electrochemical cells, (4) understanding the charge on the anode and cathode in galvanic cells, (5) chemical and electrochemical equilibrium in galvanic cell, (6) identifying the anode and cathode in electrolytic cells, (7) predicting the products of electrolysis and the magnitude of the applied electromotive force, (8) identifying the anode and cathode in concentration cells, and (9) predicting products and the electromotive force of concentration cells. Respect to identification of anode and cathode, some student believed that the species with the highest $\mathrm{E}^{0}$ in standard reduction potential tables is the anode. They used the table like the activity series for metals. In addition, Sanger and Greenbowe (1997a) and Ozkaya et al. (2003) identified that students' decision on the anode and cathode depends on the physical placement of the half cells. Students thought that anode is always the electrode that appears on the left-hand side of a diagram and the cathode is always the electrode on the right. Moreover, it was found 
that students lack an understanding of the need for and purpose of a standard half-cell (Garnett \&Treagust, 1992b; Sanger \& Greenbowe, 1997a). According to Ogude and Bradley (1996) students were unable to tell which electrode was the anode or cathode and which of those was the positive or negative electrode in an electrolytic and galvanic cell. Concerning the current flow in electrochemical cells, research studies indicated that students had a wrong idea that electrons move through the electrolyte at the cathode and pass through electrolyte to emerge at the anode (Ceyhun \& Karagolge, 2005; Garnett \&Treagust, 1992b; Loh et al., 2014; Ozkaya et al., 2003; Sanger \& Greenbowe, 1997b; Rahayu et al., 2011). In addition, some students had a notion that cations transport the electrons through solution while some of them though that the electrons flow through solution without any assistance from the ions. Some students also believed the salt bridge supplies electrons to complete the circuit while some of them thought that the salt bridge does not assist current flow (Ceyhun \& Karagolge, 2005; Garnett \&Treagust, 1992b; Ozkaya et al., 2003; Sanger \& Greenbowe, 1997b; Rahayu et al., 2011). Respect to charge on the anode and cathode, Garnett and Treagust (1992b) indicated that students' ideas about the charged electrodes in galvanic cells were inaccurate. Some students believed that the anode is negatively charged and because of this it attracts cations; the cathode is positively charged and because of this it attracts anions. On the contrary, some students thought that the anode is positively charged because it has lost electrons; the cathode is negatively charged because it has gained electrons. This scientifically incorrect idea was also identified in the study of Ceyhun and Karagolge (2005). Moreover, students thought that there is not any difference between chemical and electrochemical equilibrium established in a galvanic cell. In determining the electrolysis process, students had a wrong idea that no reactions occur if inert electrodes are used. In addition, students thought that the same reactions will occur at each electrode if identical electrodes connected to the battery (Garnett \&Treagust, 1992b; Sanger \& Greenbowe, 1997a; Ozkaya et al, 2003). 
Moreoever, students believed that water is an inert solvent that cannot be oxidized or reduced (Loh et al., 2014). Furthermore, Ogude and Bradley (1996) found that students believed that an electric current (battery) breaks the electrolyte into positive and negative ions during electrolysis. This scientifically incorrect idea was also identified among the senior high school students in the study of Rahayu et al. (2011). These results indicated that students could not explain the working principle of the electrolytic cell. Regarding the calculation of cell potential for electrolytic cell, some students obtained a positive $\mathrm{E}^{0}$ value without considering the fundamental concept that electrolytic cells involve nonspontaneous reactions with negative potentials (Garnett \&Treagust, 1992b; Sanger \& Greenbowe, 1997a).

\subsection{Research on the Case-Based Instruction in Science Education}

While the use of the case-based instruction in the science education has been minimal, it has been gaining popularity in recent years. The case-based instruction has been used successfully over the past several years at undergraduate, high school, and elementary school levels in science education.

\subsubsection{Research on the Case-Based Instruction in Undergraduate Science Education}

In the literature, some studies focused on the design of case-based instruction and presented examples of the use of this instruction in undergraduate courses, generally in chemistry and biology courses. On other hand, some studies investigated students' ideas about studying on a case and usefulness of case-based instruction. Moreover, researchers explored the effect of case-based instruction on other variables such as understanding, attitudes, and higher order thinking skills.

Smith and Murphy (1998) described the applications of case-based instruction to lecture and laboratory session in two undergraduate biology courses: anatomy and physiology, and introductory biology. In addition, this 
study presented students' ideas about these courses. In the anatomy and physiology course, students worked on the cases representing a patient with a variety of symptoms related to organ systems. Using cases students were provided opportunity to apply scientific knowledge they had learned to a real life situation. Firstly, they discussed the cases and answered the questions that followed the cases by their own or in groups. Then, all class discussed their responses on the cases. At the end of the course, students were asked to evaluate the course by responding on the course evaluation form. Students' responses indicated that they thought that cases were helpful and made the course enjoyable. Unlike anatomy and physiology course, introductory biology course included laboratory hours as well as lecture hours. In introductory biology courses, students were provided cases and they were expected to investigate the problem given in the case in the laboratory. This type of design aimed to tie the science process concepts learned during the lectures with its applications in the laboratory. In other words, the goal was to develop students' scientific process skills such as observation, recording, experimental design, data interpretation, and analysis. Students' evaluations of the course indicated that although they perceived the cases presented in the introductory biology course as challenging, they stated that the cases were interesting and rewarding.

As an example from environmental chemistry course, Cheng (1995) described the integration of case study into the environmental chemistry curriculum. In this study, the author improved the environmental chemistry curriculum by using cases in order to make the curriculum interesting and challenging to the students. In this revised curriculum, students were presented cases including a real serious pollution problem in Hong Kong. They were asked to assess the feasibility of a number of methods to remove the pollution problem by considering various factors such as the cost, the design, operation, and maintenance of equipment. Then, all class tried to determine the appropriate method to remove the pollution by the help of their teacher. They 
outlined the chemical process required for methods and assessed their feasibility. During the class, they tried to reach a best solution for the pollution. According to observations of the author, students were enthusiastic to the subjects and they perceived the subjects more open and lively than the descriptions in the textbooks.

Regarding the use of cases in undergraduate chemistry courses, Lantz and Walczak (1997) presented an example of cased-based instruction used in an introductory chemistry class. Authors' aim of using this kind of instruction was to provide students real-world context for the chemical principles, and the interaction of science, technology, and society. They also intended to demonstrate the scientific process. In their article, they described the case called "Hommers Mining Dilemma" which was about the principles of electrochemistry in the context of copper mining. This case was used in a class had 55-60 students and the class worked on it for 55 minutes three times a week. The aim of using this case was to introduce the difference between pyrometallurgy and hydrometallurgy and help students determine the relationship between the sign of cell potential and spontaneity of an electrochemical reaction at various temperatures. Before the first lesson, students read the case and answered the question given in the case. In the class, firstly, the case was summarized, and social and environmental issues were discussed. Then, fundamental chemical issues presented in the case were explored by the help of questions asked by the teacher. After that, the decisions or actions of the character in the case were discussed. In addition to discussion, students did experiments as a small group in order to determine whether these actions were feasible. They also investigated alternative processes. Experimental results of each group were written on the blackboard and discussed in the class. After the case-based instruction, students were given homework and required to answer several questions. For example, they were asked for the most important issue raised during the case, for the most 
important chemical concept learned or used during the case, and for contributions of the discussion to their learning.

Similar to Lantz and Walczak (1997), Challen and Brazdil (1996) described three examples of cases used in introductory chemistry classes. They described some classroom experiences related to cases and students feedback about the use of cases. The cases were based on the topic of empirical and molecular formulas, molecular shapes, Lewis Structures, reaction enthalpies, gas laws, solubility products, and colligative properties. Each case was illustrated in different styles. One of the cases based on gas laws and presented a space agency's plan about sending a balloon to the space. In this case, students were provided different options about characteristic of balloon and they were expected to give an advice to the agency about the balloon. Students were read the cases and they discussed their decisions as both small group and whole class. For this case, 50 minutes class period was recommended. In the second case, students were provided an article about a molecule, nicotine. Regarding this case, students were divided into groups of six students per group and each group examined different aspects of the nicotine such as shape of the molecule, Lewis structures, and reaction enthalpies. Each group shared their results with other groups before reporting to whole class. In the third case, students were provided some background information about a city's water supply and some issues that cause the quality of water such as lead pollution. Students were requested to identify the pollutant and determine a method for eliminating it. In addition, they had to write a report to give the city. For this assignment, students worked as a group and each group concerned a specific aspect of the problem such as identifying source of the lead pollution and lowering levels of lead in the water. Then, each group shared their findings with other groups and combined their reports. To get feedback about the use of cases, after each case, students' views on the value of cases as a tool for discussion and benefits of them in their understanding were examined through questionnaires. Students reported that cases were useful as a framework for 
discussion and such a method was helpful to increase their understanding since cases enabled them to apply their knowledge to realistic situations.

Different from the previous studies, Jones (1997) presented a different case activity to help general chemistry students develop an awareness of the relevance of science to daily life. Participants consisted of 27 honors students from several of science majors in their freshman or sophomore year. The course involved a lecture section, meeting four times a week, and one hour per week group discussion. There was one case activity on a jury trial in the discussion sections lasted four weeks. The purpose of this activity was to discuss the scientific, sociological, moral, ethical, religious, and legal aspects of the case related to drug usage. During the first week of discussion section, students were randomly divided into groups containing different number of members and given roles as judges $(n=3)$, defendant $(n=1)$, jury $(n=5)$, witnesses $(n=12)$, lawyers $(n=4)$ and reporters $(n=2)$. After organization of roles, the students having same roles met and identified their individual tasks. During next two weeks of class, the trial was carried out. In the last week, students met and discussed the case and wrote group reports. Then, these reports were presented in the class. Member of jury asked questions and reporters summarized the activities at the end of each trial days. Author stated that students found this activity as enjoyable and interesting since it made the science more relevant in students' lives. The author suggested adapting this kind of activity for a course for both chemistry and non-science majors.

Besides presenting examples of case materials and uses of them during the courses, some studies also presented descriptive results about the usefulness of case- based instruction and its effects on other variables. For example, Cornely (1998) used cases as an assignment to assist students' learning about the biochemical pathways of the cell in an undergraduate biochemistry course. He investigated students' ideas about exercise based on cases. The class consisted of 51 students was divided into groups of 3-5 students and each group was assigned a different case randomly. The cases 
described a disease and included a series of questions related to symptoms of it. The groups of students are supposed to solve the presented case by using their course textbook, campus library, and even local health professionals outside of class. After solving the case, students are required to write a short paper that describes the solution of their case and then present to the class in 15-minute oral presentations. Each written work and prasentation were graded. At the end of the semester, students were asked to rate a series of 30 statements which were in a 5-Likert type: strongly agree, agree, neutral, disagree, and strongly disagree. The results of this survey indicated that most of the students (\%76) viewed that studying on a case as a valuable exercise. Some students also wrote unsolicited comments about case exercise on the evaluation form. They generally stated that they found cases as enjoyable and interesting and they made the subject more relevant. In addition, based on his experiences in the course, author thought that the use of case studies in a biochemistry course encouraged students' interest and active participation in the learning of biochemistry.

Similar to previous studies, Wilcox (1999) investigated students' views about use of cases during the undergraduate course. This study was conducted with 285 students enrolled in anatomy and physiology course over five quarters. Shorter cases with brief narratives were used in a class period. Cases generally dealt with health problems occur in human anatomy. For example, one of the cases related to problems in the cardiovascular system. Students read the cases either outside of the class or in the class. Students were asked to work with a partner to answer the questions followed the cases. After pair work, all class discussed their answers. At the end of the courses, the researcher asked students about the usefulness of the case in helping them understand the subject and their ideas about the future use of cases. Related to usefulness of the case studies $65.2 \%$ of the students rated the case studies as "useful", $25.3 \%$ of the students rated them as "somewhat useful" whereas 9.5\% students rated them as "not useful". Regarding the future use of the case studies, many students (67.1 
$\%$ ) thought that case studies should be kept as it was, and $15.2 \%$ of them suggested increasing their use. However, $17.7 \%$ of the students stated that case studies should be eliminated. These results supported the previous studies found that case-based instruction is valued highly among students.

In the literature, there were also studies that explored not only students' views about case-based instruction but also the interaction between their views and other variables. For example, Ertmer, Newby and MacDougall (1996) examined how students respond to and approach case-based instruction regarding their levels of self-regulation. 58 first-year veterinary students, enrolled in a biochemistry laboratory course, were classified as high and low levels of self-regulation based on two self-regulated learning inventories. During the course, students worked on cases which described an animal distress. Each case included the information about animal's symptoms, physical characteristics of the animal, and laboratory results. Students were required to determine the diagnosis for the animal's condition and to recommend a plan for treatment in a group work. After each group decided to a treatment, all class discussed their recommendations and tried to find the most probable treatments. With the exception of the cases completed during the lab meetings students were asked to complete three cases individually in different times during the semester. After each of these cases, semi-structured interviews were conducted with nine students who had high and low levels of selfregulation to explore how students respond to and approach the case-based instruction. Regarding students' reactions to case-based instruction, during the interviews, some motivational characteristics which are students' interest in using cases, their perceived value of cases and their confidence in learning from this instruction were examined by open-ended questions. To define their approaches to the instruction, students were asked about what they did during case analysis, how they organized their approaches, how they felt while working on the case, and what they did when they encounter a difficulty. Analysis of students' reactions to case-based instruction indicated that at the 
beginning of the semester most of the students thought that case-based instruction was more interesting than their other classes. However, at the end of the semester, three students with low self-regulation stated that case studies were becoming tedious due to studying long time on the same things. Although three students with low levels of self-regulation had a narrow view of the value of cases at the beginning of the semester, case-based approach was valued most as the semester went. Students thought that cases would help them remember more and this would affect other course work and career goals. However, in the category of students' confidence, all students, especially students with low selfregulation, generally expressed concern about their confidence for learning from cases. They were less confident due to a lack of knowledge and external factors (time and length of laboratory). On the other hand, analysis of students' approaches to case-based instruction revealed that their approaches were limiting and facilitative. High self-regulated students more tended to use reflective strategies while dealing with difficult cases. They were aware of their own thinking and they behaved in a strategic manner persistently. They also seemed to enjoy the challenge of a difficult case and benefit from their efforts during case-based instruction. However, low self-regulated students felt frustrated with difficult cases and they generally used habitual strategies when learning difficulties occurred. Briefly, this study emphasized that students' level of self-regulation play an important role in shaping their responses and approaches in a case-based instruction. It was concluded that case-based instruction might not be effective if students lack the skills needed to regulate their learning.

Different from the previous descriptive studies, Knight et al. (2008) evaluated the students' learning and attitudes toward the case-based instruction. They adopted case-based approach to an upper-division cell and molecular laboratory course in undergraduate level over two semesters, spring and fall 2007. In each semester, four cases lasting 2-3 weeks were introduced to the students. Nineteen and 20 students were enrolled in the laboratory course 
during the spring and fall semesters, respectively. The course included experiments, internet research, class discussion, written exercises, brief student presentations, and occasional short lectures. Cases were based on Chick Cell Culture, Cytoskeletal Dynamics, Microarrays, and Human Ancestry. In each case, students were introduced a story which told a suspicious event or presented a dilemma. In that course, cases were typically presented in four phases. First, each case was read to the class by a volunteer student. Second, students worked in a group and brainstormed the case about 10 minutes. Third, students discussed the question related to the case: what do we know? In addition, they were asked to answer what they need to know and generate questions that could be answered through online research or laboratory experiment. Students were given 30 minutes to complete the third phase. In the fourth phase, students reported the results of their group work to the class and then selected questions were investigated independently or in small groups. In this study, four types of assessment were conducted to evaluate students' learning and their attitudes toward the course: Attitudinal assessment (spring, $n$ $=18$ ), videotaped interviews (spring, $n=8$ ), module-specific learning assessments (fall, $n=18$ ), and summative learning assessment (spring and fall, $n=38$ ). To assess attitudes, students were asked to rate two statements, one statement about preference of case-based instruction and one statement about careers in biology before and after the course. Students' attitudes towards the course and the use of cases were also elicited during one-on-one interviews. To assess students learning outcomes, students were asked responded to a core content question before and after the use of each case module. Finally, as a summative learning assessment, students were required to write a reflection paper about what they had learned from their experiences during the course and how they had learned those things. Results of attitudinal assessment indicated that students maintained their positive attitude toward case-based instruction during the course. In addition, students' enthusiasm on a career in biology slightly increased after case-based instruction. Interview results supported to 
students' positive attitudes toward case-based instruction and revealed the benefits of this kind of instruction. Students thought that case-based instruction makes biology relevant, and promotes scientific thinking, learning from peers, and retention and synthesis of ideas. Moreover, students' learning increased after the use of cases. Students responses on the questions related to the case modules indicated more detailed information when compared to their responses given before the each case. That is, students' post responses included more relevant concepts. Finally, students reported that they learned laboratory techniques (74\%), real-world applications (24\%) something about scientific writing and reading (58\%) and how to solve problems (29\%), and acquired group work skills (58\%) in their reflection papers.

Similar to Knight et al. (2008), Hutchinson (2000) used case studies to investigate the effectiveness of case-based approach in developing students' understanding of fundamental chemistry concepts. He also explored students' critical thinking skills before and after the case-based instruction. Chemistry concepts were the atomic molecular theory, kinetic molecular theory, periodicity and valence, chemical bonding and electron pair sharing, properties of polyatomic molecules, atomic structure and valance, chemical bonding and molecular structure, energetics of chemical reactions, and spontaneity of chemical reactions. Participants of the study were 221 students taking General Chemistry course. In the course, each case presented relevant experimental observations for development of a chemistry concept mentioned above. The teacher led the class discussion with questions using the Socratic Method. By this method, the teacher facilitated students to get into in a process called inductive reasoning. Students tried to understand the development of the chemistry concept with the process of questioning, observing, and model building. This process was repeated until the questions were answered satisfactorily. Each case data was completed in two or three of the 50-minute slots and then was discussed. Data were collected through pre-instruction quiz, post-instruction exam, and survey on the evaluation of case-based instruction at 
the end of the course. Comparisons of pre-instruction quiz and post-instruction exam indicated that students demonstrated improvement in their understanding of chemical concepts and most of them corrected their incorrect answers given in the pre-instruction quiz. On the survey, students were asked to rate the contributions of case-based instruction to their success in learning chemistry, ease in learning chemistry, interest in chemistry, retention of chemical concepts, ability to solve problems, skill reading and analyzing new material, and understanding of chemical concepts. In addition, students were also asked to select three opinions which they were most strongly agreed from a list of 13 opinions of which some are negative and some are positive. The result of the survey revealed that students' opinions about the use of case-based instruction were positive. Almost all students $(90 \%)$ thought that their understanding of chemical concepts was "significantly enhanced" or "somewhat enhanced". Moreover, $65 \%$ of them stated that their problem solving ability was enhanced by case-based instruction. Although students thought that case-based instruction contributed to their learning, they had also some negative feelings about case-based instruction. For example, the most popular opinion (60\%) selected from the list was "Sometimes I feel like I know the answers, I just don't know how to say them the way the grader wants". This indicated that students were generally anxious about explaining their answers during the instruction. On the contrary, the second most selected opinion (approximately $42 \%$ ) was positive: "I finally feel like I am understanding chemistry, rather than just trying to memorize chemistry." Therefore, they thought that casebased instruction is effective for their learning chemistry even if they thought it has some negative characteristics.

Besides presenting results from descriptive statistics some research studies also utilized inferential statistics to reveal the effects of case-based instruction on other variables. For example, Ayyildiz and Tarhan (2012) investigated the effect of case-based instruction on pre-service teachers' attitudes toward chemistry lesson. The participants of this study consisted of 63 
primary school student teachers enrolled in General Chemistry lesson at a university in Turkey. In the chemistry lessons, the students were provided cases involving real-life problems or situations on the topics of properties and states of matter, elements and compounds, solutions and mixtures, physical and chemical changes, chemical reactions, acids and bases, solubility and precipitation throughout a semester. With question and answer technique, students were encouraged to actively participate in the lesson. In addition, it was benefited from brainstorming, animations and videos during the instruction. Students' attitudes toward chemistry lesson were assessed before and after case-based instruction by administering the 5-point Likert type Attitude toward Chemistry Lesson Scale developed by Acar and Tarhan (2008). Participants' attitude scores were compared by paired sample t-test analysis and it was found that students' attitudes toward chemistry lesson increased significantly after the case-based instruction $(t=16.69, p<.05)$. After the instruction, most of the students thought that chemistry learning was easy, interesting and important. In addition, students valued chemistry learning and recognized its role in their life and environmental problems.

In another study, Cliff (2006) examined the role of using case studies on the remediation of 42 sophomore students' misconceptions about respiratory physiology. The author tested the prevalence of four misconceptions related to respiratory physiology before and after the instruction on respiratory physiology by utilizing a conceptual diagnostic test consisting of two-tiered question. In this study, directed case approach was utilized (Cliff \& Wright, 1996) and the carbon monoxide poisoning was selected as a topic of the case. This study conducted with one case which focused on only one of four misconceptions: "The partial pressure of oxygen in the blood is determined by hemoglobin saturation". Before studying this case, the students had worked on three cases during the course. Students received the case for at least a week before the lecture and they answered the questions of the case outside of class. They were free to work together in groups and to use 
of any sources of information. Then, students turned in their written answers on the day of the lecture. Individual students read their answers to the class and class discussion about each question was conducted. After the lecture, graded written answers were given to the students. At the end of the study, the significance of the changes between students' pre- and posttest performances (from incorrect to correct or from correct to incorrect) was determined by a non-parametric statistical test, the McNemar test for significance of change. The result of analysis was revealed that case-based instruction remedied $36 \%$ of the misconception. However, there was no change in the frequencies of other three misconceptions which were not addressed by the case study. Results suggest that case studies are useful in helping students overcome their misconceptions and improve their conceptual understanding since it provides students to confront their wrong ideas about the subject matter.

Different from the previous studies, Rybarczyk et al. (2007) conducted an experimental research study to investigate the effectiveness of case-based learning approach on students' learning gain and higher-order thinking skills compared with traditional approach (lecture method) on the topic of cellular respiration. Data were collected from 157 students enrolled in either undergraduate general biology or introductory cell biology courses. Participants consisted of both non-biology and biology majors. Classes were randomly assigned as an experimental $(n=94)$ and a control group $(n=63)$. While the experimental group was taught by case-based instruction the control group was taught by traditional approach, i.e., lecturing. For case-based instruction, one case based on the process of aerobic cellular respiration was taught in interrupted case study format. During the instruction, students firstly read the case scenario including an actual event about the death of a girl from rotenone poisoning after washing her dog with flea dip. Then, they brainstormed causes of death, analyzed data from an autopsy report, and integrated knowledge about cellular respiration to the explain reason of the event in the case. An average of 100 minutes was spent for this instruction. In 
this study, students' learning and higher-order thinking skills were assessed by pre- and post-tests which included multiple choice, short answer, open-ended, and true-false type questions. Results of the t-test analysis indicated that students in the experimental group achieved a significantly higher learning gain when compared with students in the control group $(t=5.09, p<.0001)$. The students' answers on the higher-order thinking questions demonstrated that case-based instruction promoted usage of higher-order thinking skills. Students in the experimental group performed better on these questions relative to the students in the control group. In addition to examining the effectiveness of case-based instruction on students' learning and higher-order thinking skills, in this study, it was also examined whether case-based instruction effectively addressed the common misconceptions. Regarding the students' responses on one of multiple choice questions related to a particular misconception (breathing and cellular respiration are synonymous), at the end of the study, it was revealed that the number of students, who answered the question correctly on the post-test, are more in the experimental group than those of in the control group. However, data provided insufficient evidence in terms of clarifying students' misconceptions. The result of chi-square statistical analysis indicated that there was not a significant relation between the change in students' answer on the misconception question and their assigned group $\left(\chi^{2}(2,120)=5.21, p>\right.$ $.05)$.

Similar to Rybarczyk et al. (2007), Sendur (2012) investigated the effectiveness of case-based instruction on students' chemistry achievement through an experimental research. Data were collected from 62 first-year engineering students enrolled in two sections of a general chemistry course. Each course section was randomly assigned as an experimental $(n=32)$ and a control group $(n=30)$. While the subject of gas laws was instructed, the control group followed traditional instruction and the experimental group was taught by case-based instruction throughout twelve lecture hours. During the case-based instruction, six cases related to gas laws were implemented in a 
small group format. Groups were consisted of one low, one high, three average achieving students based on their achievement scores in mid-term chemistry exam. Before the each case-based instruction, the case was given the students to be searched from books and the internet. Students tried to answer the questions related to each case as a part of their investigation. During the instruction, all of the students shared their findings to their group and discussed their answers. Then, the findings of the each group were presented by the reporters and discussed as a whole class. The whole class discussion continued until reaching a consensus about solutions related to the cases under teacher guidance. In this study, students chemistry achievement were assessed by Gas Laws Achievement Test consisted of 25 multiple-choice items and by semistructured interviews. The achievement test was given to both groups as pre and post-tests to compare the effects of case-based instruction and traditional instruction on the understanding of gas laws. In addition, at the end of the study, a semi structured interview was conducted with nine students from each group. The results of the one-way ANOVA revealed that the chemistry achievement mean score of the students instructed by case-based instruction was significantly higher than that of students taught by traditional instruction $(F(1,60)=20.476, p<.05)$. In addition, the analysis of interviews indicated that a high percentage of the students in the experimental group could correctly explain daily life examples using gas laws. Moreover, the most of the students in the experimental group stated that case-based instruction was enjoyable and interesting.

Another experimental research in the field of chemistry education was conducted by Ayyildiz and Tarhan (2013) to investigate the effects of casebased instruction on undergraduate students' understanding of gases, liquids, and solids, preventing misconceptions and attitudes towards chemistry lessons. Data were collected from 52 fresman students from the Department of Science Teaching at a university in Turkey. A pre- and post-test experimental design was utilized in this study. Students were stratified randomly in experimental (n 
=25) and control group (27). While the students in the experimental group were instructed by case-based instruction, those in the control group were taught in teacher-centered way. During the case-based instruction eight cases were provided to the students. The cases were simple real problems in daily life and solved through question and answer technique, brainstorming, animation shows, videos, and presentation technique active in the class. Before the intervention, a prerequisite knowledge test consisting of 25 multiple choice items were administered to students to identify their prerequisite knowledge before learning the subject of gases, liquids, and solids. At the end of the study, the gases, liquids, and solids achievement tests were given to students to assess students learning after the treatment. These achievements test were composed of 15,15 , and 12 multiple choice items with open-ended parts, respectively. For determination of undergraduate students' attitudes toward chemistry lesson before and after the intervention, Attitude towards Chemistry Lesson Scale developed by Acar and Tarhan (2008) was used. The scale consisted of twenty five 5-point Likert type items, ranging from strongly agree to strongly disagree. The results of independent sample t-tests showed that there were statistically significant differences between groups in terms of understanding of gases $(t=$ 9.05, $p<.05)$, liquids $(t=11.97, p<.05)$, and solids $(t=17.05, p<.05)$. In addition, the achievement test results indicated that the number and percentage of misconceptions of the experimental group students were fewer those of the control group students. According to the results obtained from the attitude scale, the frequencies in the positive answers of experimental group increased at the end of case-based instruction. Students instructed by case-based instruction found chemistry lesson more interesting than students taught by traditionally. In addition, students in the experimental group had more positive beliefs about the importance of chemistry in real-life than those in the control group. 


\subsubsection{Research about the Case-Based Instruction on High School and Elementary School Science Education}

In the literature, there are research studies focused on only design of case-based instruction or both the design of the instruction and effects of it on other variables. These studies allow us to see examples of case-based instruction in science courses in elementary schools, and those in biology, chemistry and physics courses in high schools. Moreover, effects of case-based instruction on different variables were investigated by the researchers.

Gabel (1999) explored the effect of case-based instruction on developing students' critical skills and stimulating their interest in learning science at the elementary level. Data were collected from observations notes, videotaping, student written materials, computer network communication, and teacher interviews. In this study, three cases were applied. During the casebased instruction, students were firstly given instruction on what they were to do. Then, students worked on the case in small groups. After the case was read in the groups, each group defined the problems embedded in the case. Then, the groups identified the main problem and decided how it could be fixed. After small group works, all problems were listed on the board by the teachers. The main problem found by each group and the solutions of them were discussed as a whole class. In addition, using Venn diagrams the problems presented in all cases were compared and contrasted. Results of the study indicated that students' interest in learning science was stimulated through case-based instruction since they wanted to know more about the related science topic or the effect of the problem presented in the case and they were more concerned about seeking to uncover the source of the problem during the instruction. Author stated that students' interest also stimulated higher levels of thinking. To determine the higher order thinking skills, students' statement s during the discussion were categorized according to Bloom's Taxonomy. Statements indicating analysis, synthesis, and evaluation were considered higher order thinking skills. While $28 \%$ of the student discussion statements 
were classified as critical thinking in the first case, $74 \%$ of those referred critical thinking in the third case.

Regarding the design of case-based instruction, Richmond and Neureither (1998) presented the way they used cases in the first year biology course at high school in order to engage students to the course and achieve the objectives related to concepts of biology and nature of scientific process. For example, in the case related to cholera, students examined the things that cause cholera and their characteristics. In addition, they investigated how the organism causing cholera kills people. Students worked in groups, designed their own experiments, gathered data, interpreted results, and discussed their results with the whole class. In addition, they developed individual papers explaining their findings and interpretations about the case. At the end of the case activity, students were asked what they liked best about the activity. Many students reported that they had established connections to their science and non-science classes in the first time. Authors suggested that science objectives could be achieved by using cases studies although each case based on a single concept.

Beside the design of a case-based instruction, some researchers investigated the effect of case-based instruction on different variables in the context of different courses. For example, Adali (2005) explored the effects of case-based instruction and gender on fifth grade students' achievement in science and their attitudes toward science. Eighty eight students from two classes of a science teacher at an elementary school participated in this study. The classes were randomly assigned as experimental and control group. In the experimental group, students were instructed by case-based instruction on the topic of viruses, bacteria, fungi, and protists. On the contrary, in the control group, same topic was taught by traditional teaching methods. In experimental group, four cases were utilized throughout the study lasted four weeks. Each week, students worked on one of the cases during five science classes. Each case presented problems taken from real life and included some questions 
related the case. Cases were given students a week before the lesson. Students were asked to read the cases and search the topic from books, journals etc. During the lesson, firstly one of the students was requested to read the case loudly. Then, teacher and all students talked each other if there was unclear part in the case. After that, students analyzed the case and discussed their answers to the questions in small groups consisting of six or seven students. Each group member had a role such as speaker, reporter and coordinator. All groups are requested to write their answers to the case questions on the paper and then one of the members of each group, speaker, tell their answers to the class and discussed their answers. In this study, science achievement test developed by the researcher and an attitudes toward science scale were administered to both groups before and after the instruction. Results of the ttest statistical analyses indicated that students of experimental group had higher academic achievement in science $(t=6.223, p<.05)$ and higher attitudes toward science $(t=4.841, p<.05)$ than those of control group. Moreover, results of four separate one way ANOVA revealed that there was not a significant effect of interaction between treatment and gender with respect to students' achievement in science and their attitudes toward science.

Similar to Adali (2005), Saral (2008) also investigated the effect of case-based learning on students' achievement in biology concepts. Different from the study of Adali (2005), this study conducted in the unit of human reproductive system during a high school biology course. In addition to student achievement, this study explored students' perceived motivation in biology. Participants of the study were 80 tenth grade students (48 males and 32 females) from four biology classes of the two teachers in a private high school. One class of each teacher was randomly assigned as experimental group and control group. In the experimental groups, students learned human reproductive system by means of the cases. Students searched the answers of the questions posed in the cases and discussed their ideas. While dealing the cases, students sometimes worked individually at their homes and worked in a 
small group in the class. In addition, a computer lab and small library were provided to the experimental group. After searching, students shared their ideas with their small groups and discussed on them. Following small group discussion, all groups presented their answers to the class. On the other hand, in the control group, students were taught by teacher's explanations and web based notes provided by the department of biology of the high school. To reveal the effect of case-based instruction on students' learning and motivation, an achievement test based on human reproductive system and a motivation questionnaire about intrinsic goal orientation, extrinsic goal orientation and task value were administered to both groups before and after the instruction on the unit of reproductive system. The results of one-way Multivariate Analysis of Variance (MANOVA) indicated that case-based learning developed students' academic achievement $(F(1,78)=9.29, p<.0125)$ and task value $(F(1,78)=10.81, p<.0125)$. In addition, it was found that there was no significant difference in both groups in terms of students' perceived intrinsic goal orientation and extrinsic goal orientation after the treatment although the scores of students exposed to case-based instruction were higher than those of students exposed to traditional instruction.

A similar study was carried out by Cakir (2002) with $7410^{\text {th }}$ grade students in a high school biology course on the topic of nervous system. This study considered the effect of interaction between case-based instruction, learning styles, and gender on students' understanding of the biology concepts. In addition, this study investigated the effect of the case-based instruction on different variables such as higher order thinking skills and attitude toward biology. While experimental group students were instructed with case-based instruction in a small group format control group students were taught by traditionally designed instruction. Cases were written on scenarios presenting real life events and followed by questions. In experimental group, students were asked to read the cases and search the related topic before the class. At the beginning of the class, one student read the case loudly. Then, teacher and 
all students talked each other if there was unclear part in the case. After that, throughout the half of the class period students analyzed the case and discussed their answers to the questions in small groups consisting of five students. After each group formed a single report included their answers whole class discussion began and each group shared their answers with other groups. During the instruction, teacher monitored students during group work, provided assistance, and guided the class discussion. After each case, students were asked to write an individual report by answering open-ended questions which asked what they did during group work, what they had learned from the case, what they think about the usefulness of cases in their learning of the biology subject, and what were their weaknesses and strengths during the casebased instruction. In this study, students' learning styles were determined by administering Turkish version of Kolb's Learning Style Inventory at the beginning of the study. At the beginning and end of the study, all students' academic knowledge and higher order thinking skills were assessed by 25 multiple choice questions developed by the researcher. In addition, all students were asked to answer five essay type questions to measure their ability to organize, integrate and explain their ideas, which was called students' performance skills in this study. Moreover, attitude toward chemistry scale developed by Geban, Ertepinar, Yilmaz, Altin, and Sahbaz (1994) was used to assess students' attitude toward biology by adapting the items of the scale to biology. This scale and essay type questions were also given as pre- and posttest to all students in this study. During the study, students' performances in experimental group were measured through individual reports, group reports, and peer evaluation form. Results of MANOVA revealed that there was a significant improvement in performance skills $(F(1,72)=25.239, \mathrm{p}<.05)$ and academic knowledge $(F(1,72)=7.259, \mathrm{p}<.05)$ of students taught by casebased instruction. However, there was not a significant effect of case-based instruction on students' attitudes toward biology and higher order thinking skills when compared to traditional instruction. In addition, students' learning 
styles and gender did not have significant effect on students' performance skills, attitudes toward biology, higher order thinking skills, and academic knowledge.

Another study in the field of biology was conducted by Skolnick (2009) to investigate the effect of case-based instruction on academic achievement, science attitudes, problem solving skills, and team work skills of high school biology students. For this aim, a quasi-experimental research design was conducted by using eleven Living Environment classes, five teachers and 252 high school biology students over a semester consisting two quarters. All students were typically $9^{\text {th }}$ and $10^{\text {th }}$ grade high school students. In the study, participants and teacher were divided into two groups. Group One consisted of five classes of 121 total students was taught by two teachers, Group Two consisted of six classes of 131 total students was taught by three teachers. In the first quarter of the study, Group One instructed by case-based instruction while Group Two followed standard teaching methodology. However, at the beginning of the second quarter, the teachers switched methodologies. In other words, Group Two was taught by case-based instruction whereas Group One was instructed by standard teaching method the second quarter of the study. The units covered in the first quarter were The Nature of Life, Biology as Science, Basic Chemistry, Chemical Compounds of Life, The Cell, Classification of Living Things, and Organization of the Biosphere. On the other hand, five biology units were taught in the second quarter, which were Biomes of the Earth, Human Ecology, Evidence of Evolution, Modern Theory of Evolution, and Mendelian Genetics. During the case-based instruction, five and four cases were used in the first and second quarter of the study, respectively. During the intervention, three formats of case teaching were applied as mixed: Interrupted Case, Directed Case, and Problem Based Learning Format, To assess students' academic achievement, pre-test assessment, Otis-Lennon School Ability Test (OLSAT), was given to students' in both groups at the beginning of the study. The scores of this test were used 
as covariate in this study. In addition, two researcher-made achievement test was applied in both groups after each quarter to compare students' academic achievement across the groups. For assessment of science attitudes, the Test of Science Related Attitudes (TOSRA) scale was given all students' at the end of each quarter. It was composed of seven subscales, namely social implication of science, normality of scientists, attitude toward scientific inquiry, adoption of scientific attitudes, enjoyment of science lessons, leisure interest in science, and career interest in science. Each of the subscales contained ten 5-point Likert-type items, ranging from "strongly disagree" to "strongly agree". Regarding assessment of problem solving and teamwork skills, a survey instrument consisting of 20 Likert items for problem solving skills and 13 Likert type items for teamwork skills was administered to all students at the end of first and second quarters. For data analysis, ANCOVA was utilized for all dependent variables. The results revealed that case-based instruction had a significant improvement on academic achievement during the first quarter $(F(1,198)=14.025, p<.05)$, but not the second quarter $(F(1,195)=1.597, p$ $>$.05). Moreover, case-based instruction had a significant improvement on four of seven subscales of science attitudes during the second quarter of the study: social implications of science $(F(1,187)=6.812, p<.05)$, normality of sciences $(F(1,187)=4.088, p<.05)$, attitude toward scientific inquiry $(F(1$, $187)=5.319, p<.05)$, and enjoyment of science lessons $(F(1,187)=7.084, p$ $<.05)$. Furthermore, students exposed to case-based instruction during the second quarter of the study demonstrated greater problem solving skills ( $F(1$, $187)=27.195, p<.05)$ and teamwork skills $(F(1,187)=23.684, p<.05)$ than the students taught by traditionally.

Case-based instruction was also used in other areas of science such as physics. For example, Ozkan and Azar (2005) compared the effect of casebased instruction and traditional instruction on $609^{\text {th }}$ grade students' achievement in the unit of heat and temperature and their attitudes toward physics course. Two classes of a physics teacher from the same school were 
randomly assigned as experimental and control groups. Experimental groups were instructed by cases while control group were taught traditionally. In this study, an achievement test and an attitude scale were administered as pre and post-test. The achievement test involving 15 multiple choice questions and 10 fill in the blank questions was developed by the researcher. The attitude scale was a 5-point Likert type scale ranging from strongly agree to strongly disagree. Based on the t-test statistical data analysis, it was seen that students in the experimental group were significantly successful in physics achievement test than those in the control group $(t=2.374, p<.05)$. In addition, the researcher found that case-based instruction increased students' attitudes toward physics course, although it was not significant.

Regarding the studies conducted in high school chemistry courses, researchers generally investigated the effect of case-based instruction on remediation of misconceptions. In these studies, they also examined other variables that affected by the case-based instruction. For example, Yalcinkaya, Tastan-Kirik, Boz, and Yildiran (2012) explored the effect of case-based instruction on coping with high school students' alternative conceptions regarding chemical kinetics utilizing nonequivalent pre-test post-test control group design. In this study, two classes of a chemistry teacher from the school were selected and each they were randomly assigned to groups as experimental $(n=25)$ and control group $(n=28)$. Experimental group students were instructed by using cases in a small group format, while control group students were taught traditionally. During the treatment, 12 cases about concepts of chemical kinetics such as definition of reaction rate, factors affecting reaction rate and reaction mechanisms were utilized. Each cases generally based on analogies associated with real life events and included several questions. In experimental group, students firstly analyze cases and answered the questions in small groups. After that, all the groups presented their answers to the class and discussed their answers. The discussion continued until the students reached a plausible and logical response to the questions. During the case- 
based instruction, the teacher guided the groups while working on the cases and handled the class discussion. To determine the students' alternative conceptions regarding chemical kinetics, a reaction rate concept test including 16 two-tier items and seven multiple choice items were administered to the students at the beginning and end of the study. In addition, semi-structured interviews conducted with six students from both groups after the analysis of the post-test in order to detect the reasons behind their answers on the concept test. To determine the effect of case-based instruction on dealing with students' alternative conceptions, analysis of variance (ANOVA) was run for the posttest scores. Results indicated that there was a significant mean difference between students' understanding of chemical kinetics when taught case-based instruction as compared to traditionally designed chemistry instruction $(F(1$, $51)=9.347, p<.05)$. Students instructed with cases demonstrated better understanding of the concepts of chemical kinetics and had less alternative conceptions compared to the ones instructed traditionally. Moreover, interview findings supported to the results of concept test in general.

In another study, Yalcinkaya (2010) also investigated the effect of casebased instruction on remediation of students' misconceptions related to gas concepts. Different from the study of Yalcinkaya et al. (2012), this study also investigated the effect of case-based instruction on students' attitudes toward chemistry and their perceived motivation in chemistry. There were 128 tenth grade students from a regular high school and an Anatolian high school in this study. Two classes of a chemistry teacher were selected from those two schools and one class of each teacher from each school was randomly assigned as experimental group and control group. Students in the experimental groups were instructed by case-based instruction based on conceptual change conditions while the control group students were taught by traditionally designed chemistry instruction. In the experimental group, 15 written cases generally based on real-life events, experiments and specific situations related to gas concepts were used and the instruction was implemented in a small 
group format. During the instruction, students read the cases and answered the questions given in the case materials as a group consisting of four or five students under the teacher guidance. Each group wrote their answers on the case material. Afterward, each group shared their ideas to the whole class and discussed their answers until reasonable answer was found to the case questions. Meanwhile, teacher of the experimental group guided the discussion by asking open-ended and challenging questions and prompting further thinking. In this quasi-experimental design, a gas concept test included 26 multiple choice questions with five alternatives base on common misconceptions about gas concept in the related literature, an attitude scale developed by Geban et al (1994) and Motivated Strategies for Learning Questionnaire developed by Pintrich, Smith, Garcia, and McKeachie (1991) were administered to both groups of students as pretest and posttest in order to determine the students' misconceptions and their understanding of gas concepts, their attitude toward chemistry and perceived motivation before and after the instruction. Results of the two-way ANOVA based on gain scores indicated that case-based instruction was effective to overcome students' misconceptions about the gas concepts. However, significant mean scores difference between control and experimental group students' attitude toward chemistry was found only in the Anatolian high school. Regarding the perceived motivation involving intrinsic goal orientation (IGO), extrinsic goal orientation (EGO), task value (TV), control of learning beliefs (CLB), selfefficacy for learning and performance (SELP), and text anxiety (TA), results of the two-way MANOVA based on gain scores revealed that there was a significant effect of treatment on students' CLB scores $(F(1,126)=6.552$, p < .05) and a significant effect of school type by treatment interaction on students' gain values of $\operatorname{EGO}(F(1,126)=6.321, p<.05), \operatorname{TV}(F(1,126)=6.970, p<$ $.05), \operatorname{SELP}(F(1,126)=16.779, p<.05)$ and TA values $(F(1,126)=5.254, p<$ $.05)$. It was also found that there was a significant mean difference on students' CLB scores between the groups in terms of treatment on favor case-based 
instruction at both schools. In the Anatolian high school, there was a statistically significant mean difference between the groups in terms of gain EGO values, gain TV values, and gain SELP values on favor of experimental group. On the contrary, in the regular high school, there was a statistically significant mean difference between the groups in terms of gain TA values on favor of experimental group. Furthermore, there was not any significant effect of school, treatment and school type by treatment interaction on students' gain values of IGO.

In the domain of chemistry, Cam (2009) also investigated the effectiveness of case-based instruction on students' understanding of chemistry concepts. The purpose of this study was to examine the effect of case-based instruction on $11^{\text {th }}$ grade students' understanding of solubility equilibrium concepts, their attitudes toward chemistry, and their epistemological beliefs. This study also explored the effect of interaction between case-based instruction and gender on students' understanding of solubility equilibrium concepts and their attitudes toward chemistry. Similar to previous studies, nonequivalent pre-test post-test control group design was utilized in this study. In the experimental group ( $n=27)$, students were taught by case-based instruction involving cases from real-life. On the contrary, in the control group ( $n=35)$, students were instructed by traditional methods. Students' understandings of solubility were assessed at the beginning and end of the instruction by administering concept tests to both groups. In addition, attitude scale developed by Geban et al.(1994) and Schommer's (1990) epistemological belief scale were administered as pre-test and post-test to both groups in order to assess students' attitudes toward chemistry and their epistemological beliefs about chemistry. Results of two-way analysis of covariance (ANCOVA), which was carried out with treatment and gender differences as the independent variables, students' pre-test scores on the concepts test as a covariate and students' post-test scores as the dependent variable, indicated that case-based instruction method provided significantly higher achievement 
to the students than the traditional method $(F(1,58)=22.007, p<.05)$. Results of two-way ANOVA revealed that there was a significant mean difference between the experimental and the control group in terms of students' attitudes toward chemistry after the treatment $(F(1,56)=7.842, p<.05)$. However, the results of this study indicated that there was no significant mean difference between male and female students' posttest scores on concept test and attitude toward chemistry scale. Also, there was no significant effect of interaction between treatment and gender with respect to students' understanding of solubility and their attitudes toward chemistry. Moreover, based on the results of Repeated Measures Analysis of Variance it was concluded that students taught by case-based instruction had more sophisticated epistemological beliefs after the treatment. Furthermore, case-based instruction was found as an effective instructional method for remediation of students' misconceptions related to solubility equilibrium.

Another study in the field of chemistry education was conducted by Morris (2013) in order to determine the effects of using cases in conceptual science course on students' perceptions of relevance of science and their chemistry learning. 43 students from two Conceptual Science classes (Group 1 and Group 2) participated in the study. This intervention was conducted over a period of nine weeks which covered two units of the conceptual science course: (1) the Atomic Structure and the Periodic Table and (2) Bonding. While one of the classes received the treatment during the first unit, the same class was taught in a traditional manner during the second unit, In other words, each class was instructed by using cases, but in different unit. In both units, one case were used to introduced the topic. During the treatment, students firstly worked with the case individually. This was then followed by small group and whole class discussions based on the answers of the questions related to the case. In the study, students' perceptions of relevance of science to their lives were measured by an online 5-point Likert type perception of relevance scale (from strongly disagree to strongly agree) administered before and after the 
intervention. In addition, interviews were conducted with three students from each class. On the other hand, students' chemistry learning was assessed via pre- and post-content assessment before and after each unit. Pre- and postchemistry learning assessments consisted of several types of items such as multiple choice, matching and fill in the blank items. The descriptive results for the perception of relevance survey indicated that the mean of students' response before and after using cases are nearly identical, which were 3.29 and 3.30 for pre-treatment and post-treatment, respectively. In other words, there were not any significant shifts in students' perceptions of relevance to their lives throughout the study. Regarding the impact of using cases on students' learning, the gain scores for pre- and post-assessments indicated that both classes have a higher gain score for the unit taught through a case than that for the unit taught by traditionally. Finally, all interviewees thought that using cases made science more interesting and helped their chemistry learning.

\subsection{Summary}

Over the last twenty years, it has become clearer to science educators that constructivist approaches facilitate producing meaningful understanding of science (Baran \& Darling-Hammond, 2008; Duit \& Trequest, 1998).

Constructivist approach emphasizes students' active role in their learning by constructing their own knowledge rather than receiving knowledge from teacher. In addition, constructivist approach situated learning tasks in realistic and relevance contexts, and embedded learning in a social intereaction. Casebased instruction provides students an active and social learning environment in which they examine authentic problems presented by cases in small groups. Although case-based instruction has long been used in law, business and medical schools, it has recently gained popularity in science education at undergraduate, high school, and elementary school levels. Studies in literature revealed that case-based instruction caused significant improvement on students' learning, attitude toward the course, motivation, and higher order 
thinking skills such as problem solving and critical thinking skills. Although case-based instruction has been studied in science education, its implementation in secondary education, especially in chemistry, is few. Moreover, there is little empirical evidence on the impact of case-based instruction on motivation to learn chemistry and chemistry self-efficacy beliefs. To reveal the effect of case-based instruction on different cognitive and motivational variables at different grade levels with different subjects will enlighten the researchers and teachers in the field of science education about the effectiveness of the case-based instruction. This study will empirically provide data about whether case based instruction increases students' chemistry learning, attitudes toward chemistry, motivation to learn chemistry, and chemistry self-efficacy beliefs. 


\section{CHAPTER 3}

\section{PROBLEMS AND HYPOTHESES}

This chapter presents the main and sub-problems of the study and related hypotheses.

\subsection{The Main Problem and Sub-problems}

\subsubsection{The Main Problem}

The purpose of this study was to investigate the effect of case-based instruction on $11^{\text {th }}$ grade students' understanding of electrochemistry concept, their attitude toward chemistry, chemistry self-efficacy beliefs, and motivation to learn chemistry. Moreover, $11^{\text {th }}$ grade students' conceptions about electrochemistry and their ideas about case-based instruction were explored.

\subsubsection{The Sub-problems}

1) Is there a significant mean difference in the students' understanding of electrochemistry concept when using case-based instruction as compared to traditionally designed instruction?

2) Is there a significant mean difference in the students' attitude toward chemistry when using case-based instruction as compared to traditionally designed instruction?

3) Is there a significant mean difference in the students' intrinsic motivation to learn chemistry when using case-based instruction as compared to traditionally designed instruction? 
4) Is there a significant mean difference in the students' perceptions regarding relevance of learning chemistry to personal goals when using case-based instruction as compared to traditionally designed instruction?

5) Is there a significant mean difference in the students' chemistry selfefficacy beliefs for cognitive skills when using case-based instruction as compared to traditionally designed instruction?

6) Is there a significant mean difference in the students' self-efficacy beliefs for chemistry laboratory when using case-based instruction as compared to traditionally designed instruction?

7) What are the students' conceptions about electrochemistry topics?

8) What are the students' views about case-based instruction?

\subsection{Hypotheses}

$\mathrm{H}_{0} 1$ : There is no significant mean difference in the students' understanding of electrochemistry concept when using case-based instruction as compared to traditionally designed instruction.

$\mathrm{H}_{0} 2$ : There is no significant mean difference in the students' attitude toward chemistry when using case-based instruction as compared to traditionally designed instruction.

$\mathrm{H}_{0} 3$ : There is no significant mean difference in the students' intrinsic motivation to learn chemistry when using case-based instruction as compared to traditionally designed instruction?

$\mathrm{H}_{0} 4$ : There is no significant mean difference in the students' perceptions regarding relevance of learning chemistry to personal goals when using casebased instruction as compared to traditionally designed instruction?

$\mathrm{H}_{0}$ 5: There is no significant mean difference in the students' chemistry selfefficacy beliefs for cognitive skills when using case-based instruction as compared to traditionally designed instruction? 
$\mathrm{H}_{0} 6$ : There is no significant mean difference in the students' self-efficacy beliefs for chemistry laboratory when using case-based instruction as compared to traditionally designed instruction? 


\section{CHAPTER 4}

\section{METHOD}

This chapter provides information about the methodology of the study under ten main sections: research design of the study, subjects of the study, variables of the study, instruments, implementation, treatment fidelity and verification, analysis of data, threats to internal validity, assumptions, and limitations.

\subsection{Research Design of the study: Experimental Design}

This study utilized the nonequivalent pre-test post-test control group design as a kind of Quasi-Experimental Design. In this design, although the groups are randomly assigned as control and experimental, the subjects are not randomly assigned to these groups; instead already formed groups are assigned to the treatments (Fraenkel \& Wallen, 2006). Regarding this study, classrooms which had been already formed by the schools were assigned to the treatments rather than subjects. Two treatment groups were pre-tested, administered a treatment, and post-tested. Table 2 presents the design of the study.

Table 2 Research Design of the Study

\begin{tabular}{llll}
\hline Groups & Pre-test & Treatment & Post-test \\
\hline EG & ECT & Case-based instruction & ECT \\
& ASTC & & ASTC \\
& CMQ & & CMQ \\
& HCSS & & HCSS \\
\hline CG & ECT & Traditional instruction & ECT \\
& ASTC & & ASTC \\
& CMQ & & CMQ \\
& HCSS & HCSS \\
\hline
\end{tabular}


In this table, EG represents experimental group instructed by case-based instruction while CG stands for the control group taught by traditional instruction. ECT is the Electrochemistry Concept Test, ASTC is the Attitude Scale toward Chemistry, CMQ is the Chemistry Motivation Questionnaire, and HCSS is the High School Chemistry Self-Efficacy Scale.

In this study, ECT was administered to both experimental and control groups before the instruction to determine whether there was a significant mean difference between two groups in terms of students' pre-existing knowledge about electrochemistry concepts. Moreover, ASTC, CMQ and HCSS were applied as pre-tests to both groups to compare the groups in terms of students' attitude toward chemistry, their motivation to learn chemistry and chemistry self-efficacy beliefs, respectively. After instruction, ECT, ASTC, CMQ and HCSS were again administered to both groups as post-tests to determine the effect of treatment -case-based instruction vs. traditional instruction- on students' understanding of electrochemistry concepts, attitude toward chemistry, motivation to learn chemistry, and chemistry self-efficacy beliefs.

\subsection{Subjects of the Study}

The target population of this study was determined as all the $11^{\text {th }}$ grade students in Ankara. However, since data collection from all $11^{\text {th }}$ grade students in Ankara has some difficulties in terms of financial and time limitations, the accessible population was identified as all $11^{\text {th }}$ grade students in the Mamak district in Ankara. There were 17 high schools in the Mamak district. The researcher got permission from those schools for the study (see Appendix A). High school chemistry teachers in Mamak were asked whether they could implement case-based instruction in their chemistry lessons. Then, the schools in which the teachers accepted to participate in the study were chosen as implementation schools in this study. Therefore, three Anatolian high schools were selected from the identified accessible population by the convenience 
sampling technique. Two classes of the same teacher from each school participated in this study. All teachers were female and had over ten years' experience in the teaching profession. One class of each teacher was randomly assigned as experimental and control group. Table 3 shows the distributions of classes with respect to teachers and instructional method.

Table 3 Distributions of Classes with Respect to Teachers and Instructional Method

\begin{tabular}{ccccc}
\hline & & Experimental Group & & Control Group \\
\cline { 3 - 3 } School & & Case-based Instruction & & Traditional Instruction \\
\hline $\mathrm{A}$ & Teacher 1 & Class A & & Class B \\
$\mathrm{B}$ & Teacher 2 & Class C & & Class D \\
$\mathrm{C}$ & Teacher 3 & Class E & & Class F \\
\hline
\end{tabular}

A hundred and thirteen $11^{\text {th }}$ grade students (47 boys and 66 girls) participated in this study. While 59 students were instructed by case-based instruction in experimental groups, 54 students were instructed by traditional instruction in control groups in total. The ages of participants were between 16 and 17. Table 4 gives information about class size with respect to groups.

Table 4 Sample size

\begin{tabular}{ccccc}
\hline \multirow{2}{*}{ School } & \multicolumn{2}{c}{ EG } & \multicolumn{2}{c}{ CG } \\
\cline { 2 - 5 } High School & Class & Class size & Class & Class size \\
& $\mathrm{A}$ & 18 & $\mathrm{~B}$ & 19 \\
Total & $\mathrm{C}$ & 17 & $\mathrm{D}$ & 16 \\
& $\mathrm{E}$ & 24 & $\mathrm{~F}$ & 19 \\
\hline
\end{tabular}




\subsection{Variables of the Study}

\subsubsection{Independent Variables}

The independent variable of this study was instructional method. This variable had two categories: case-based instruction and traditional instruction.

\subsubsection{Dependent Variables}

The dependent variables of this study were students' understanding of electrochemistry concepts measured by ECT, their attitude towards chemistry measured by ASTC, their intrinsic motivation to learn chemistry and perceptions regarding relevance of learning chemistry to personal goals measured by CMQ, and their chemistry self-efficacy for cognitive skills and chemistry laboratory measured by HCSS. Briefly, there were overall six dependent variables in the current study.

Table 5 presents all the characteristics of dependent and independent variables.

Table 5 Characteristics of the variables

\begin{tabular}{cccc}
\hline $\begin{array}{c}\text { Type of the } \\
\text { variable }\end{array}$ & Name of the Variable & $\begin{array}{c}\text { Nature of the } \\
\text { Variable }\end{array}$ & $\begin{array}{c}\text { Type of } \\
\text { the Data }\end{array}$ \\
\hline $\begin{array}{c}\text { Dependent } \\
\text { Dependent } \\
\text { Dependent }\end{array}$ & $\begin{array}{c}\text { Understanding of electrochemistry } \\
\text { Attitude toward chemistry } \\
\text { Intrinsic motivation to learn } \\
\text { chemistry }\end{array}$ & $\begin{array}{c}\text { Continuous } \\
\text { Continuous } \\
\text { Continuous }\end{array}$ & $\begin{array}{c}\text { Interval } \\
\text { Interval } \\
\text { Interval }\end{array}$ \\
$\begin{array}{c}\text { Rependent } \\
\text { Dependent }\end{array}$ & $\begin{array}{c}\text { Chemistry self-efficacy for cognitive } \\
\text { personal goals } \\
\text { skills }\end{array}$ & Continuous & Interval \\
$\begin{array}{c}\text { Dependent } \\
\text { Independent }\end{array}$ & $\begin{array}{c}\text { Self-efficacy for chemistry laboratory } \\
\text { Instructional Method }\end{array}$ & $\begin{array}{c}\text { Continuous } \\
\text { Categorical }\end{array}$ & $\begin{array}{c}\text { Interval } \\
\text { Nominal }\end{array}$ \\
\hline
\end{tabular}




\subsection{Instruments}

\subsubsection{Electrochemistry Concept Test (ECT)}

ECT was developed by the researcher to assess students' understanding of electrochemistry concepts. In the first stage of the test development, the instructional objectives of the electrochemistry unit were identified based on the national chemistry curriculum of the Ministry of National Education (MoNE) (see Appendix B). In the second stage, chemistry text books (e.g., Eubanks, Middlecamp, Pienta, Heltzel, \& Weaver, 2006; MEB, 2008; 2010; Moore, Stanitski, Wood, Kotz, \& Joester, 1998), research articles and dissertations on the topic of electrochemistry (e.g., Ekici, 2007; Lin, Yang, Chiu, \& Chou, 2002; Ozkaya, Uce, \& Sahin, 2003; Thompson \& Soyibo, 2002; Toprak, Ozkan, \& Alpat, 2006; Yuruk, 2000; 2007) were thoroughly reviewed to form items. The topics in the test included the relationship between matter and electric energy, standard potentials of electrodes, and electrochemical cells. The initial form of the test consisted of 35 multiple choice items with five alternatives. It was examined in detail by four chemistry educators and one chemist in terms of content validity and its format. In addition, chemistry educators were asked to fill the table of test specification. Based on their recommendations related to the length, expression, and purposes of the items, necessary revisions were made on the test. After this revision, five questions were removed from the test. Then, ECT (see Appendix C) was piloted at high schools in Ankara by administrating it on 131 high school students who had already learned the electrochemistry concept beforehand. To check the difficulty level of the test and how well it discriminates between high achievers and low achievers, item analysis was conducted through Item and Test Analysis program (ITEMAN). The criterion for item difficulty is proportion of examinees who answered the item correctly. It is usually denoted as $p$ and ranges between 0.0 and 1.0. Higher $\mathrm{p}$ values indicate that the difficulty level of the test is easy (Crocker \& Algina, 1986; Cunningham, 2005) According to the 
scale statistics calculated by ITEMAN, mean item difficulty was found as .5, which means that, on average, 52 per cent of the students answered the items correctly (see Table 6). This result indicated that test items were neither too easy nor too difficult. Besides difficulty level, items should discriminate between high achievers and low achievers. The criterion for item discrimination is the biserial correlation index varying between -1.00 and +1.00 . The greater the discrimination index, the more likely the items were answered correctly by more students with high overall test scores than those with low test scores (Crocker \& Algina, 1986; Cunningham, 2005). The results of ITEMAN revealed that the average item discrimination index was .45 , which is acceptable. Furthermore, the reliability coefficient was found as .73 (see Table 6).

Table 6 Scale statistics for the ECT

\begin{tabular}{ll}
\hline N of Items & 29 \\
N of Examinees & 131 \\
Mean & 14.954 \\
Variance & 19.067 \\
Std. Dev. & 4.367 \\
Skew & -0.704 \\
Kurtosis & -0.049 \\
Minimum & 3.000 \\
Maximum & 23.000 \\
Median & 16.000 \\
Alpha & 0.727 \\
SEM & 2.279 \\
Mean P & 0.516 \\
Mean Item-Tot. & 0.335 \\
Mean Biserial & 0.451 \\
\hline
\end{tabular}

However, when item statistics were analyzed in terms of item difficulty and item discrimination indices for each item, it was seen that there was a need to change or revise some items. If biserial correlation index for the correct response is greater than .40 , it means the item is functioning quite 
satisfactorily. If it is between the values of .30 and .39 , the item is functioning somehow good. If it is between the values of .20 and .29 , the item needs revision. If it is below .19, the item should be deleted or completely revised (Ebel, as cited in Crocker \& Algina, 1986). In the item analysis output, although biserial correlation index for many items was greater than .30 , this index for five questions $(1,13,17,19$, and 25$)$ was between .20 and .29, and for three questions (21, 23 and 29) was below .19. In addition, proportions of correct answer for some items $(13,17,19,21,23,25$, and 29) were very low. For item analysis, biserial correlation index for alternatives should be also checked. Positive value is desirable for correct response alternatives while negative value for the other alternatives. This case indicates that students who performed well on the test tended to answer the item correctly. In other words, the item was discriminating well between high and low scorers (Crocker \& Algina, 1986; Cunningham, 2005). According to the results of ITEMAN, the key, the wording of the items, and alternatives were checked again to determine whether they contained any ambiguity. Regarding the items whose biserial correlation indices were below .19, the researcher tried to increase the probability of high achiever students' selection of correct response by making the questions more coherent. For example, in question 29, students were asked to find the incorrect statement, but most students selected the first alternative which was correct. As a consequence, the results of the ITEMAN program for this item warned the researcher to check the key because the first alternative worked better. This may result from students' carelessness while answering the item. That is, students may tend to find the correct statement rather than the incorrect. Using negative words or phrases in the item is also inadvisable while writing multiple choice items (Haladyna, 1997). Therefore, the item and alternatives were revised by asking students to find the correct statement. Moreover, it was seen that item 21 and 23 might have been ambiguous to the students since some alternatives included more than one judgment which might 
have made it difficult to decide whether those alternatives were correct or incorrect. Therefore, these two items were revised in terms of wording.

Concerning the items whose biserial correlation indices were between .20 and .29, the researcher checked the wording of the items. For example, in item 19, students were asked to calculate the time in minutes required for the process of electrolysis. However, high proportion of students answered this item in terms of seconds, not minutes. Therefore, this question was revised by changing the word "minutes" to "seconds". Moreover, the format of question 13 was changed. This question was an algorithmic question related to concept of concentration cells. After the pilot study, it was rewritten to ask conceptual question. Furthermore, item 25 was dropped from the test by considering the length of the test. Since the related objective was measured by another item, it was not problematic for the content of the test.

The revised final form of the test which was comprised of 27 multiple choice questions with five alternatives is presented in Appendix D. In addition, a table of test specifications is given in Appendix E. In the study, this test was administered to students in both the experimental and the control groups before and after the treatment.

\subsubsection{Attitude Scale toward Chemistry}

This scale was developed by Geban et al. (1994) to measure students' attitude toward chemistry as a school subject. It was a unidimensional scale and contained 15 items on a 5-point Likert-type scale, ranging from "strongly disagree" to "strongly agree". Before using this scale in this study, pilot study was conducted with 387 students in the eleventh grade to check the validity and reliability of the scale. The evidence of construct validity was calculated with "item-total score" correlation using the Pearson's correlation coefficient (r). All items had moderate or high positive correlation with total score $(.46<r$ $<.78$, Hinkle, Wiersma, \& Jurs, 1998). These results verified that all items contribute to the validity of the instrument. The Cronbach alpha reliability 
coefficient was found as .91 , which indicates a high reliability. In the main study, this scale was administered to students in experimental and control groups before and after the treatment. The instrument is given in Appendix F.

\subsubsection{Chemistry Motivation Questionnaire}

This questionnaire was originally developed as Science Motivation Questionnaire (SMQ) to assess students' motivation to learn science by Glynn and Koballa (2006). It was translated into Turkish and adapted to the chemistry subject by Cetin-Dindar and Geban (2010), called as Chemistry Motivation Questionnaire (CMQ). The original version of SMQ contains 30 items with a 5-point Likert type scale (never, rarely, sometimes, usually, and always). It assesses six components of motivation all of which consist of five items: intrinsically motivated science learning, extrinsically motivated science learning, relevance of learning science to personal goals, responsibility (selfdetermination) for learning science, confidence (self-efficacy) in learning science, and anxiety about science assessment. The items related to intrinsically motivated science learning component refer students' motivation to learn science for a feeling of enjoyment (e.g., "I enjoy learning the science") while those belong to extrinsically motivated science learning component cover students' motivation to learn science for an award such as grade and job (e.g., "I think about how learning the science can help my career"). Another component, relevance of learning science to personal goals assesses students' motivation to learn science for its relevance to their future goals (e.g., "The science I learn relates to my personal goals"). The component called as responsibility for learning science provides information about the degree of students' control over what they do and how they do (e.g., "I put enough effort into learning the science"). The items related to confidence in learning science refer to students' beliefs about their abilities to succeed in the field of science (e.g., "I believe I can master the knowledge and skills in the science course"). The last component assesses students', anxiety about science assessment (e.g., 
"I am nervous about how I will do on the science tests"). The Turkish and adapted version of the SMQ consists of 30 items with a 5-point Likert type scale as in the original version. However, it has five dimensions which were intrinsically motivated chemistry learning (six items), relevance of learning chemistry to personal goals (five items), self-determination for learning chemistry (seven items), confidence in learning chemistry (seven items), and anxiety about chemistry assessment (five items). The reliability of coefficient estimated by Cronbach's alpha was found between .75 and .84 for each dimension of the questionnaire. Although all the items were the same with the original version, the items related extrinsically motivated science learning factor were distributed to other factors in the adapted version. Regarding the aim of the study, two dimensions of the CMQ (intrinsically motivated chemistry learning and relevance of learning chemistry to personal goals) were utilized. Firstly, the two-factor structure model was tested by a pilot study. The questionnaire consisting of eleven items was administered to 417 eleventh grade students in high schools in Ankara. For construct validity, Confirmatory Factor Analysis was carried out by using AMOS 21 (Analysis of Moment Structures, Arbuckle, 2012). Firstly, the Chi square $\left(\chi^{2}\right)$ to degrees of freedom $(d f)$ ratio was checked for model fit. There is no commonly agreed-upon maximum value for an acceptable model for this ratio. While some researchers claimed that ratio of less than 2 indicates a good-fitting model (e.g., Tabachnick \& Fidell, 2007), some of them put forward that the value between 2 and 5 is also acceptable (e.g., West, Taylor, $\& \mathrm{Wu}, 2012$ ). The $\chi^{2 / d f}$ ratio was found as 2.24, which was considered a representative of a good fit. The other goodness of fit statistics also illustrated a good fit. Root-Mean-Square Error of Approximation (RMSEA) indicates a good model fit if it is less than or equal to .05 and indicates an adequate fit if it is less than or equal to .08 (Byrne, 2010). The RMSEA was found to be .074, presenting an adequate fit. The Comparative Fit Index (CFI) should be above the .90 for a satisfactory model fit (Tabachnick \& Fidell, 2007). The CFI was found as .94 which is 
considerably above that threshold. The Normed Fit Index (NFI) should also exceed .90 for a well-fitting model. The NFI was found to be .91 . In conclusion, the goodness of fit statistics pointed out that a two-factor structure provided a satisfactory model fit.

Moreover, in the pilot study, Cronbach alpha reliability coefficients were calculated by using Statistical Package for Social Sciences (SPSS). Cronbach alpha values were found as .83 and .72 , for the dimensions of relevance of learning chemistry to personal goals and intrinsically motivated chemistry learning, respectively. In the study, this questionnaire was administered to students in experimental and control groups before and after the treatment. The instrument is given in Appendix G.

\subsubsection{High School Chemistry Self-Efficacy Scale}

This scale was developed by Capa-Aydin and Uzuntiryaki (2009) to assess chemistry self-efficacy beliefs of high school students. The scale contains 16 items with a 9-point Likert type response format, where 1 refers to "very poorly" and 9 refers to "very well". This scale has two sub-dimensions of chemistry self-efficacy named chemistry self-efficacy for cognitive skills and self-efficacy for chemistry laboratory. These sub-dimensions are comprised of 10 and 6 items, respectively. The items belong to the former refers to students' beliefs in their ability to use intellectual skills in chemistry (e.g., "How well can you define the fundamental concepts in chemistry?"). On the other hand, the items related to self-efficacy for chemistry laboratory refers to students' beliefs in their ability to accomplish laboratory tasks (e.g., "How well can you carry out experimental procedures in the chemistry laboratory?"). In this study, this scale was piloted by administering it on 124 eleventh grade high school students in Ankara. In order to analyze the construct validity Confirmatory Factor Analysis was carried out through AMOS 21.0. Following fit indices which indicated a quite satisfactory model fit were obtained: $\chi^{2}(103)=$ 203.672, $\mathrm{CFI}=.92, \mathrm{NFI}=.85$ ve $\mathrm{RMSEA}=.069$. Moreover, in the pilot study, 
Cronbach alpha reliability coefficients were calculated by using SPSS. The alpha values were .86 and .95 for chemistry self-efficacy for cognitive skills and self-efficacy for chemistry laboratory, respectively. In the study, this scale was administered to students in experimental and control groups before and after the treatment. This scale is given in Appendix $\mathrm{H}$.

\subsubsection{Interviews}

Semi-structured interviews were conducted with a total of 12 students from both experimental and control groups after the post-tests were administered. For interviews, six students from each group (one male, five females) were selected based on their answers on the post ECT. Thus, three high and low achiever students from each group attended the interviews. The purpose of the interviews was to get deep information about students' way of thinking while answering the questions in the ECT. In addition to students' scores on ECT, their conceptions were compared in the light of interviews. Each interview lasted about 50-60 minutes. All interviews were audio-taped and transcribed verbatim.

During the interviews, students examined their responses for the ECT and were asked how they answered the questions. In addition to items of ECT, students were asked what they think about the following mechanism as presented in Figure 2. Specifically they were asked what they think about whether the clock works or not, and why. 


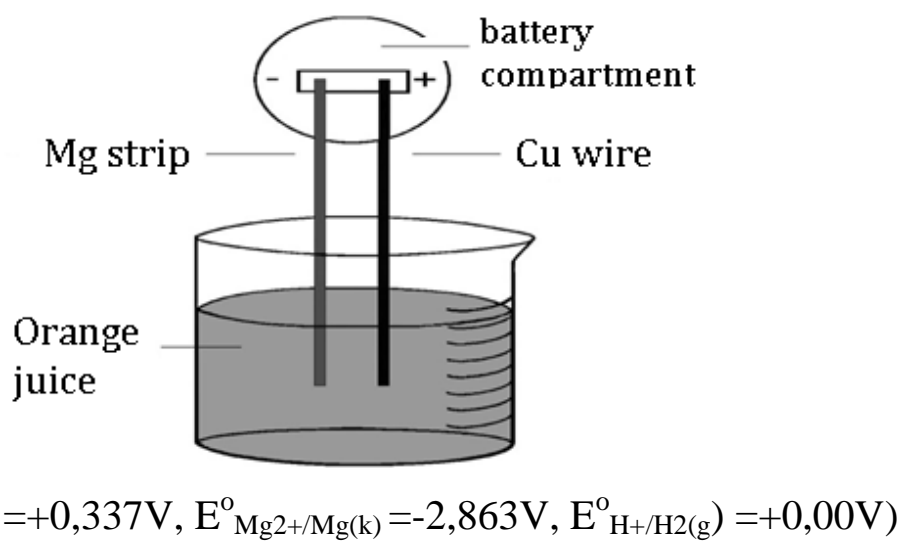

Figure 2 An orange-juice clock setup with metal wires.

\subsubsection{Feedback Form for the Case-based Instruction}

This form includes seven open-ended questions related to the casebased instruction. It was adapted by the researcher from the studies of Sungur (2004) and Yalcinkaya (2010). The aim of this feedback form was to get students' opinions about the case-based instruction. In this study, this form was administered to students only in experimental groups. Students' responses to the forms were analyzed qualitatively, which were discussed in Chapter 5. This form is given in Appendix I.

\subsection{Implementation}

This study was conducted throughout nine weeks during the spring semester of 2010-2011 academic years at three schools in Ankara. A total of 113 students from two classes of eleventh grade in each school participated in this study. In each high school, one of the classes was randomly assigned as the experimental and the other class was assigned as the control group. Both classes were taught by the same teacher in each school. All students in three schools followed the same national chemistry curriculum of the MoNE and they were taught the same concepts but by different instructional methods. The experimental group was instructed by case-based instruction while the control 
group was instructed by traditionally designed chemistry instruction. The classroom instruction was three 45-minute periods per week for each school. Before the treatment, all teachers participated in the study were trained about case-based instruction with the emphasis on the role of teacher and the students. Besides, teachers were informed about how to implement the instructional materials prepared for the electrochemistry unit by the researcher. At the beginning and the end of the treatment students in both groups were given ECT, ASTC, CMQ and HCSS as pretest and posttest.

Before the study, two main arrangements were done: developing cases and creating the final form of instruments used in this study by ensuring their validity and reliability. Although the cases developed by the researcher are fictional, they are based on real life. The researcher designed the cases based on scientific ideas which students should learn by the help of several scientific articles (e.g., Bushman, 2010; JCE Staff, 2000; Kulandaisamy, Rethinaraj, Adaikkalam, Srinivasan, \& Raghavan, 2003; Nakiboglu, Toscali, \& Nisli, 2003; Yong, 2005; Informatics Association of Turkey (TBD), 2010; Ciftlik, et al.,2009), and educational websites (e.g., Chymist, Illinois Community College Board; Ministry of Environment and Urbanization; New Zealand Institute of Chemistry; Oakland Schools; The Scientific and Technological Research Council of Turkey (TUBİTAK); Westminster College).While writing the cases, the characteristics identified by Herreid (1997) and the process defined by Wasserman (1994) were considered. First, the researcher find daily life events or problems related to objectives of electrochemistry unit in the national chemistry curriculum. Once the events were decided, the scenarios were formed. Several experts in chemistry education were requested to review the cases for the appropriateness of the content, grade level, and objectives. Then, the researcher met with reviewers to discuss and revise the cases. In the process of preparation of cases, case drafts underwent several cycles of review, discussion, and revision. In this study, a total of eight cases based on real-life events or socio-scientific issues, or experiments were used to teach the 
concepts of electrochemistry. The student and teacher version of a sample case used in the experimental groups are given in the Appendix $\mathrm{J}$ and $\mathrm{K}$. The topics of the cases were electroplated materials, cleaning tarnished silver materials, accumulator, recycling silver from old roentgenograms, fruit clock, clean energy, electronic waste, and protection from corrosion. Brief description of each case was presented below.

First case was called as "Gold Goods". This case was prepared to teach Faraday's law and the relationship among redox reaction, electric current and material changes. The case presents a dialog between two cousins watching a TV program. The program introduces a house including gold goods. Based on the program, two cousins starts to talk about those gold materials in terms of whether they are completely made of gold or electroplated by gold. They share their knowledge about the process of electroplating materials by gold with each other. At the end of the case, there are ten questions about the case or the topic.

Second case called as "Silver Materials" was designed to teach students to identify reducing and oxidizing agent in a redox reaction and to balance redox reaction equations by the help of a real-life event. This case describes a dialog which takes place between two girls namely Burcu and Simge. They are talking about their silver jewelries and the problem of silver tarnish. In the text, Burcu states that she cleans her tarnished silver jewelries by taking them to a jewelry store. Accordingly, Simge is interested in cleaning her jewelries. Then, they go to the store together to make her tarnished silver jewelries. The text describes the process how the owner of the store cleans the silver jewelries with hot sodium bicarbonate solution and an aluminum foil. At the end of the cases, there are six questions in order to enable students to discuss on the reason of silver tarnish, the process of cleaning silver materials, and redox reactions underlying this cleaning process.

In the third case, namely "Accumulator", the purpose was to enable students to comprehend working principles of rechargeable batteries and accumulators. It describes an event occurred while two families were having a 
trip by their cars. They stayed at an isolated and uninhabited place for two days. At the end of their trip, one of the cars didn't start because of low battery voltage. There were no repair shops and residents around. At the end of the story, one of the characters in the story told that this problem could be solved without buying a new accumulator or going to a repair shop. However, he didn't tell the solution. In this case, students were expected to find the solution and explained the process. At the end of the case, there are five questions. For example, students were asked to give examples for rechargeable batteries different from accumulators, and explain their usage area and working principles. While applying this case, some information about types of batteries was also provided via a handout.

Fourth case called as "Roentgenograms for source of money" introduces the idea of making money by removing silver from old roentgenograms with the purpose of teaching electrolysis and industrial application of it. At the end of the case, students are asked how image occurs on roentgenograms and how silver is removed from old roentgenograms.

In the fifth case, "Fruit Clock", the main aim was to teach students working principles of electrochemical cells through a story about a fruit clock. In the story, a girl buys a clock worked with fruits as a present for her brother. The girl and her brother set up the clock by looking at the user guide of the clock and talks about the working principle of it. At the end of the case, there are five questions to enable students to discuss on the working principles of the fruit clock.

Sixth case called as "Clean Energy" describes the environmental issues and global change due to the fossil fuels. It emphasizes environmentally friendly and renewable energy sources. Regarding this issue, the case introduces news related to cars working with hydrogen fuels. At the end of the case, students are asked to explain the working principle of hydrogen fuels and the sources of hydrogen. Moreover, they are expected to discuss the rationales behind using hydrogen fuels as eco-friendly energy sources. 
Similar to sixth case, seventh case called as "Recycling gold from electronic waste" emphasizes on an environmental issue related to electronic waste. The case provides some information about the amount of electronic waste in Turkey and amount of valuable metals obtained from electronic wastes. Furthermore, it focuses on works of the Ministry of Environment and Forestry on recycling process of electronic waste. At the end of the case, students are asked to provide a method for recycling of gold from electronic waste and to explain the chemical process underlying that method.

The main objective of the last case called as "Bridge" was to teach students the concept of corrosion and the protection methods. It elaborates by giving a specific example of bridge built over a river by villagers. The bridge was made of iron. In the story, after several years, one of the abutments of the bridge under the river collapsed. While villagers control the other abutments, they realized that they were destroyed by rust. At the end of the case, students are asked about why it collapsed. They are also asked whether similar events occur in the environment or not. Finally, students are expected to give suggestions to protect abutments of the bridge from corrosion.

\subsubsection{Treatment in the Control Groups}

The students in the control group were instructed by the traditionally designed chemistry instruction. It involved lecturing method which was teacher-centered. During the instruction, the teachers defined and explained the concepts of electrochemistry verbally using their notes and wrote the formulas of the concepts on the board. Teacher role was to transmit the facts and concepts to students. Meanwhile, students simply acted as passive listeners and took notes. After teaching the concepts, teacher solved some questions on the board and students wrote them on their notebooks. After that, teacher asked some questions verbally or wrote them on the board and allocated certain time for students to solve them. While students were solving the questions, teacher sat on her table or walked around the class monitoring students. Then, one of 
the students or teacher solved the question on the board. Teacher sometimes gave students worksheets that she developed or copied from several textbooks and students were asked to solve the questions given in the worksheet. In the control group, there were not any hands-on activities or group work in class while teaching of electrochemistry concepts.

\subsubsection{Treatment in the Experimental Groups}

Students in experimental group were instructed by case-based instruction in small group format described by Herreid (1994). The same content was covered in experimental groups as in the control groups. Before the treatment, small groups which consisted of five or six students were formed by the researcher in experimental group of each school. Groups were formed based on the distribution of z-scores calculated from students' standard scores on pre-tests. The researcher aimed to form heterogeneous groups as much as possible in terms of students' chemistry achievement, attitude toward chemistry and motivation to learn chemistry determined by ECT, ATCS, and CMQ, respectively. Before the treatment, the teacher announced that students would learn the electrochemistry topic by a new method called case-based instruction in the class. She provided information about the method; explaining what it is and how it is applied in classroom settings emphasizing the roles of students in detail. Cases prepared by the researcher were used as an active learning material. At the beginning of the unit, groups of students were formed. Each class started with the teacher delivering the cases to the groups. One of the students read the case loudly to the whole class. Then, each group analyzed the case and answered the questions given at the end of the case by discussing their answers with the group members. Then, one of the group members wrote the answers the questions on the blank provided on the material. While each group was answering the questions, the teacher moved around the class, checked group works and guided students by asking open-ended and challenging questions and activating their further thinking process. When 
necessary, the teacher provided clues to students to solve the questions. After all of the groups finished their own work, the answers of the each group were shared and discussed as a whole class. The whole class discussion continued until reaching a consensus about answers under teacher guidance. In addition, numerical chemistry problems were provided to students in the experimental group as in the control group. Working on a problem in the format of small groups provided students with an active and social learning environment, in which students joined problem solving, and shared and discussed their ideas with their peers. Since all students must have the university entrance exam at the end of their last year in high school, their preparation for the exam is important in this respect. Therefore, in some classes, similar to control group, students worked on the same worksheets and solved questions.

For an example of case-based instruction, the instructional objectives related to identifying reducing and oxidizing agent in a redox reaction, and balancing redox reaction equations were taught by the help of a case called Silver Materials (See Appendix J). At the beginning of the class, groups of students were formed. The class started with the delivery of the case to each group. Then, two of the students read the case loudly to the whole class. Afterwards, each group analyzed the case and answered six questions given at the end of the case by discussing their answers with the group members. After the discussion, each group wrote their answers. The questions were:

1. Why do silver materials tend to lose their brightness and tarnish overtime? Could you write the chemical reaction equations that explains this situation? What are the oxidizing and reducing agents? Write oxidation and reduction half reactions.

2. Do you think that we could polish our silver goods? Do an experiment to polish one of your silver goods.

3. Could you write the chemical reaction equations that explains the process of polishing silver jewelries? What are the oxidizing and reducing agents? Write their half reactions. 
4. What is the function of sodium bicarbonate solution used during the cleaning process of silver jewelries? Is it important to use hot sodium bicarbonate solution? If yes, why?

5. Why is aluminum foil used during the cleaning process of silver jewelries? Can you use another material instead of aluminum foil?

6. Green color is produced on the surface of copper materials over time. What might be reason for this situation? Could you write the chemical reaction equation that explains this situation? What are the oxidizing and reducing agents? Write their half reactions.

After each group answered the first question, the teacher enabled them to share their answers and discuss as a whole class. Five-minute discussion time was given to students to argue how silver is tarnished, which chemical reaction occurs, and what the reducing and oxidizing agents are. Then, each group was provided with necessary equipment and they tried to clean a tarnished silver material by employing the process told in the case. After that, each group was asked to explain the chemical process underlying the cleaning of tarnished silver materials, to write balanced chemical reaction equation, and to identify reducing and oxidizing agents in the reaction. Firstly, each group wrote their answers on the paper. After finishing their answers, one of the students wrote his/her group answers on the black board and explained related chemical process. Then, the other groups discussed the answer under the guidance of the teacher and explained their answers. When necessary, the teacher provided clues to students to solve the questions. Discussion continued until the right balanced chemical reaction equation, oxidizing and reducing agents, and the half reactions were decided, respectively. Regarding the fourth and fifth questions, students examined cleaning process in terms of the materials used (e.g., sodium bicarbonate solution, hot water, and aluminum foil). Each group was asked what the functions of these materials were during the cleaning process. In addition, they were asked whether another material could be used instead of aluminum foil. After each group finished writing their answers, 
group answers were shared with the class and discussed. Finally, each group tried to answer the sixth question. Regarding this question, each group expressed their ideas about why copper materials turn to green overtime and which chemical reaction causes this situation. The whole class discussion continued until reaching a consensus about answers under teacher guidance. At the end of the lesson, students worked on several chemical reaction equations given by the teacher in order to balance them.

\subsection{Treatment Fidelity and Verification}

Researcher attended as an observer to the classes of the control and experimental groups. Specifically, of 21-class hour allocated for the electrochemistry unit, researcher attended 16-class hour for experimental group and 8-class hour for control group in each high school. During the observation, the researcher checked whether the topics were taught as defined in the study. In order words, the researcher tried to ensure treatment verification in both groups. For this aim, the researcher filled in a classroom observation checklist adopted from the study of Yalcinkaya (2012) for all observed classes (See Appendix L). There were 21 items including three alternatives in this checklist: yes, no, and not applicable. The items demonstrated the main characteristics of case-based instruction and traditional instruction. The descriptive results of the checklist provided evidence for implementation of case-based instruction in the experimental group and traditional instruction in the control group (see Table 7).

Table 7 The results of classroom observation checklist

\begin{tabular}{|c|c|c|c|c|c|c|c|c|}
\hline \multirow[b]{2}{*}{ Item \# } & \multicolumn{4}{|c|}{ Experimental group } & \multicolumn{4}{|c|}{ Traditional group } \\
\hline & $\begin{array}{c}\# \text { of } \\
\text { Observation }\end{array}$ & $\begin{array}{l}\text { Yes } \\
(\%)\end{array}$ & $\begin{array}{l}\text { No } \\
(\%)\end{array}$ & $\begin{array}{l}\text { NA } \\
(\%)\end{array}$ & $\begin{array}{c}\text { \# of } \\
\text { Observation }\end{array}$ & $\begin{array}{l}\text { Yes } \\
(\%)\end{array}$ & $\begin{array}{l}\text { No } \\
(\%)\end{array}$ & $\begin{array}{l}\text { NA } \\
(\%)\end{array}$ \\
\hline Item 1 & 16 & 69 & 31 & 0 & 8 & 0 & 100 & 0 \\
\hline Item 2 & 16 & 69 & 31 & 0 & 8 & 0 & 100 & 0 \\
\hline Item 3 & 16 & 31 & 69 & 0 & 8 & 100 & 0 & 0 \\
\hline Item 4 & 16 & 69 & 0 & 31 & 8 & 0 & 0 & 100 \\
\hline
\end{tabular}


Table 7 The results of classroom observation checklist (continued)

\begin{tabular}{ccccc|cccc}
\hline Item 5 & 16 & 75 & 25 & 0 & 8 & 0 & 100 & 0 \\
Item 6 & 16 & 69 & 31 & 0 & 8 & 0 & 100 & 0 \\
Item 7 & 16 & 69 & 0 & 31 & 8 & 0 & 0 & 100 \\
Item 8 & 16 & 100 & 0 & 0 & 8 & 75 & 0 & 25 \\
Item 9 & 16 & 31 & 38 & 31 & 8 & 0 & 0 & 100 \\
Item 10 & 16 & 69 & 6 & 25 & 8 & 0 & 0 & 100 \\
Item 11 & 16 & 69 & 0 & 31 & 8 & 0 & 0 & 100 \\
Item 12 & 16 & 81 & 19 & 0 & 8 & 0 & 100 & 0 \\
Item 13 & 16 & 69 & 6 & 31 & 8 & 0 & 0 & 100 \\
Item 14 & 16 & 69 & 0 & 31 & 8 & 0 & 0 & 100 \\
Item 15 & 16 & 75 & 25 & 0 & 8 & 0 & 100 & 0 \\
Item 16 & 16 & 38 & 63 & 0 & 8 & 100 & 0 & 0 \\
Item 17 & 16 & 100 & 0 & 0 & 8 & 63 & 38 & 0 \\
Item 18 & 16 & 94 & 6 & 0 & 8 & 75 & 25 & 0 \\
Item 19 & 16 & 69 & 31 & 0 & 8 & 0 & 100 & 0 \\
Item 20 & 16 & 69 & 13 & 19 & 8 & 0 & 38 & 63 \\
Item 21 & 16 & 81 & 19 & 0 & 8 & 13 & 88 & 0 \\
\hline
\end{tabular}

In addition to the observation of the researcher, three classes from the control group and six classes from the experimental group were observed by $\mathrm{PhD}$ candidates in chemistry education in order to avoid bias and obtain more reliable results in implementation process. In order to determine consistency between rates of the researcher and observers an interrater reliability analysis using the Cohen's Kappa statistic was performed. Regarding all observers, the measured Kappa values ranged from .64 to .92, indicating a good level of agreement (Landis \& Koch, 1977).

\subsection{Analysis of Data}

For data analysis of quantitative data, descriptive and inferential statistics were utilized via SPSS. As for descriptive statistics analysis, mean, median, mode, minimum and maximum values, standard deviation, skewness, and kurtosis were computed for each variable and both groups. As for inferential statistics analysis, Multivariate analysis of Variance (MANOVA) was carried out for the pre-tests and post-tests scores to determine the effect of case-based instruction on students' understanding of electrochemistry concepts, their attitude toward chemistry, their intrinsic motivation and perceptions 
regarding relevance of learning chemistry to personal goals, and their chemistry self-effcicacy for cognitive skills and chemistry laboratory. Before conducting MANOVA, the assumptions, which are normality, linearity, multicollinearity and singularity, and homogeneity of variance-covariance matrices were checked.

On the other hand, the qualitative data gathered from interviews and feedback forms for case-based instruction were analyzed inductively. That is, the researcher built the patterns, categories, or themes from the data by generating codes and organizing them (Creswell, 2007). Students' responses to the interview questions were categorized as correct or incorrect to detect students' understanding of electrochemistry. In the same way, students' written responses on feedback form for case-based instruction were categorized under three headings: students' description of case-based instruction, students' perceptions about effectiveness of case-based instruction, and difficulties students encountered during the case-based instruction. The codes subsumed under each category were:

1. Students' descriptions of case-based instruction
a. Real-life issues
b. Doing an activity/experiment
c. Working in a group
d. Dealing with a case
e. Student-centered method

2. Students' perceptions about effectiveness of case-based instruction

a. Learning
i. Effective
ii. Ineffective

b. Enjoyment

3. Difficulties students encountered during the case-based instruction 

a. No difficulty
b. Working in a group
c. Interpreting the cases
d. Answering the questions
e. Adopting the method

Finally, in order to check the treatment verification the checklists filled in by the researcher were analyzed through descriptive statistics by SPSS. In addition, inter-rater reliability for the checklist was determined by calculating correlation between the ratings of the observers.

\subsection{Threats to Internal Validity}

The internal validity means that "observed differences on the dependent variable are directly related to the independent variable, not due to some other unintended variable" (Fraenkel \& Wallen, 2006, p. 169). Possible threats to internal validity of the results of this study and the methods used to eliminate or minimize them were discussed in this section.

Subject characteristics: This threat is described as the possibility of individuals differing from one another in unintended ways such as their age, socioeconomic background, science process skills etc. (Fraenkel \& Wallen, 2006). In this study, the grade level of the students in both groups was the same and they were almost the same age (16-17 years old). Thus, these variables do not change the observed difference on dependent variable. In addition, students were not assigned to experimental and control groups randomly since already formed classes were used in this study. However, the control and experimental groups were randomly assigned to the classes. Therefore, there was no possibility of selection bias or subject characteristics threat by the researcher. Nevertheless, students might have different characteristics in each group. To minimize this threat, students' previous knowledge about electrochemistry concepts, their attitudes, chemistry self-efficacy beliefs, and motivation to learn 
chemistry were statistically checked by using MANOVA. Consequently, the groups were found to be equivalent in terms of these variables.

Mortality: It refers to loss or absence of subjects during the process of study. In this study, some of the students were excluded from the study since they did not complete one of the instruments during the post-test. In total, the number of these loses were under the $10 \%$ of the sample.

Location: This threat occurs when a different location were used for intervention or data collection (Fraenkel \& Wallen, 2006). In each school, the control and experimental group were generally in their regular class, but experimental group was sometimes in laboratory when there was a demonstration or experiment. In each school, students were given pre-tests and post-tests in their regular class. Moreover, interviews were conducted with students from both groups of each school in an empty class of the students' school. Therefore, during interviews, location was held constant for all participants in each school. In addition, the researcher collected more information to minimize the location threat for the groups.

Instrumentation: Instrumentation can be a possible threat to internal validity if the nature of research instruments is changed in some way during the study. This threat is known as instrument decay. The nature of instruments including scoring should not cause different interpretations of results over time or from one person to another person. In this study, ECT was prepared in multiple-choice form and the other questionnaires included Likert-type rating scale. Therefore, all the questionnaires had a standard scoring method. In addition, the same measuring instruments were used before and after the study, and the scoring format was not altered in any way. Thus, instrument decay was controlled. Data collector bias is another threat related to instrumentation. The characteristics of data collector (e.g. gender, age, and ethnicity) and the nature of data collection process may affect results. Data collector may unconsciously distort the data as a result of fatigue of him/her due to long or difficult scoring method. In order to prevent this threat, the same teacher was collected in each 
school under standard conditions. All data collectors were trained for standard procedure of test administration by the researcher. In addition, the researcher observed the data collection to ensure standard procedures of data collection. During the administration of the questionnaires, both groups were given same explanation and direction about the questionnaires. During the interviews, data were collected by the researcher and interviews conducted in same way for each group and each school. Therefore, the threat of data collector bias was minimized.

Testing: Improvement on the scores of dependent variables might be due to administering pre-test at the beginning of the treatment, which is called testing threat (Fraenkel \& Wallen, 2006). Pre-test may alert students about the intervention and they may remind answers of questions given in the pre-test if there is less time between pre-test and post-test. Therefore, improvement on post-test scores may be result of this situation, not intervention. In this study, pre-test was administered to both groups so the effect of pre-test on these groups was equal. In addition, the time between pre-test and post-test were approximately two months which was long enough to minimize pre-test sensitization. Therefore, testing was not a threat to internal validity for this study.

History: The results of the study might be affected by an unexpected event which is not part of the treatment. This is known as history threat (Fraenkel \& Wallen, 2006). Throughout the whole study, the researcher observed the data collection process and treatments. In addition, the researcher was in contact with teachers of each group. However, it was not noticed any unexpected event affecting the results in this study.

Maturation: Over the study, participants may change physically, intellectually and emotionally and these changes may affect results of the study. This threat is known as maturation (Fraenkel \& Wallen, 2006). In this study, all the students were at the same age and the same grade. In addition, the 
study lasted for seven weeks which is a short time to observe maturation effect. Consequently, maturation did not form a threat for this study.

Attitude of subjects: The attitude of subjects may affect the results of the study. In an intervention study, students in experimental groups thought they are superior to the students in control group since they are being studied. As a result, they perform better on the outcome variables. This is known as Hawthorne effect. The improvement on outcome variables may also be due to students' positive attitude to the new treatment not their actual improvement. This is known as novelty effect. During the treatment, there might be an interaction among students of experimental groups and control groups. As a result of this, students in control group may exert more effort than they otherwise would because the new treatment is not given to them. Therefore, they may try to be more successful than the students in experimental group, which is known as John Henry effect. In addition, the students in control group may become discouraged and demoralized since they do not take new treatment while students in experimental group are given different kind of materials and as a result they may perform more poorly on outcome variables than they would. Although it was difficult to control or observe the interaction between each group since students of experimental and control groups were in the same school, these possible threats were assumed to be minimized in the present study. Teachers made students believe that treatment is regular part of the study the same activities were conducted in both groups.

Regression: This threat can be seen when the subjects are selected because of their high or low scores (Fraenkel \& Wallen, 2006). Regression was not a possible threat since already formed groups were used in this study instead of selecting subjects based on their scores. In addition, the groups were randomly assigned as an experimental and control group.

Implementation: This threat can be observed when the instructors behave unintentionally in favor of one method over the other or when different instructors who have different qualification are assigned to different methods 
(Fraenkel \& Wallen, 2006). In this study, one teacher in each school implemented the teaching methods to both groups. In addition, the classroom observation checklists were used to minimize this threat and treatment verification was provided.

\subsection{Assumptions}

- All instruments were administered under similar conditions.

- The participants of the study completed the instruments honestly.

- Teachers participated into the study were not biased during either treatment.

- There was no interaction between students in the experimental group and the control group.

\subsection{Limitations}

- The subjects of the study were limited to 113 eleventh grade students at three Anatolian High School in Ankara during 20102011 semesters.

- This study was limited to unit of electrochemistry in high school chemistry curriculum. 


\section{CHAPTER 5}

\section{RESULTS AND CONCLUSION}

To answer the research question, one way between-subjects multivariate analysis of variance (MANOVA) was conducted on six dependent variables: students understanding of electrochemistry, attitude toward chemistry, intrinsic motivation, perceptions regarding relevance of learning chemistry to personal goals, chemistry self-efficacy for cognitive skills and self-efficacy for chemistry laboratory. The independent variable was type of the treatment. Results of the MANOVA are presented in two main sections as analyses for pre-tests and analyses for post-tests. For each section, there are three subsections. In those subsections, first, preliminary analyses are described. Second, analyses of the assumptions of MANOVA are presented. Third, results of one-way MANOVA are displayed in order to reveal that whether there was a significant mean difference between experimental and control groups with respect to the dependent variables of the study. After presentation of results of MANOVA, the results of student interviews regarding their understanding of electrochemistry concepts, students' opinions about the case-based instruction, and the results of the classroom observation checklist are presented, respectively.

\subsection{Analyses of the Pre-Tests Scores}

\subsubsection{Preliminary Analyses}

For MANOVA, the sample size requirement for each cell is at least the number of dependent variables (Meyer, Gamst, \& Guarino, 2006; Tabachnick 
\& Fidell, 2007). In addition, some authors (e.g., Hair, Black, Babin \& Anderson, 2010) suggest minimum 20 cases per cell. For this study, the independent variable is the type of treatment with two levels. Students taught by case-based instruction and students taught by traditionally designed chemistry instruction are defined as one cell. Additionally, there are six dependent variables: understanding of electrochemistry, attitude toward chemistry, intrinsic motivation, relevance of learning chemistry to personal goals, chemistry self-efficacy for cognitive skills and self-efficacy for chemistry laboratory. Maintaining a sufficient sample size for each cell (assuming 20 participants per cell) would then require a total sample of 40 . Therefore, in the current study, sample size $(N=113)$ is suitable for performing MANOVA.

Before performing the MANOVA, outliers should also be checked that might have effect on the mean. In the present study, both univariate and multivariate outliers were checked for pre- and post-test scores. Regarding univariate outliers, the box plots for each dependent variable are created by SPSS to check whether there are extreme points or outliers in the data file. For pre-test scores, the box plots for each dependent variable indicated that there were not any extreme points in the data file. However, there were seven outliers for intrinsic motivation and two outliers for chemistry self-efficacy for cognitive skills in the box plots (Figure 3). The information given in descriptive statistics (Table 8) helps me to understand whether those outlying cases are problematic or not. For this issue, the value we are interested in is the 5\% Trimmed Mean. If original mean and the trimmed mean are very similar, it indicates that the values are not too different from the remaining distribution (Field, 2009; Tabachnick \& Fidell, 2007). In other words, outliers do not have important influence on the mean. In this study, original means and the trimmed means were similar for pre-test scores of intrinsic motivation and chemistry self-efficacy for cognitive skills. Therefore, these outliers remained in the data file. 

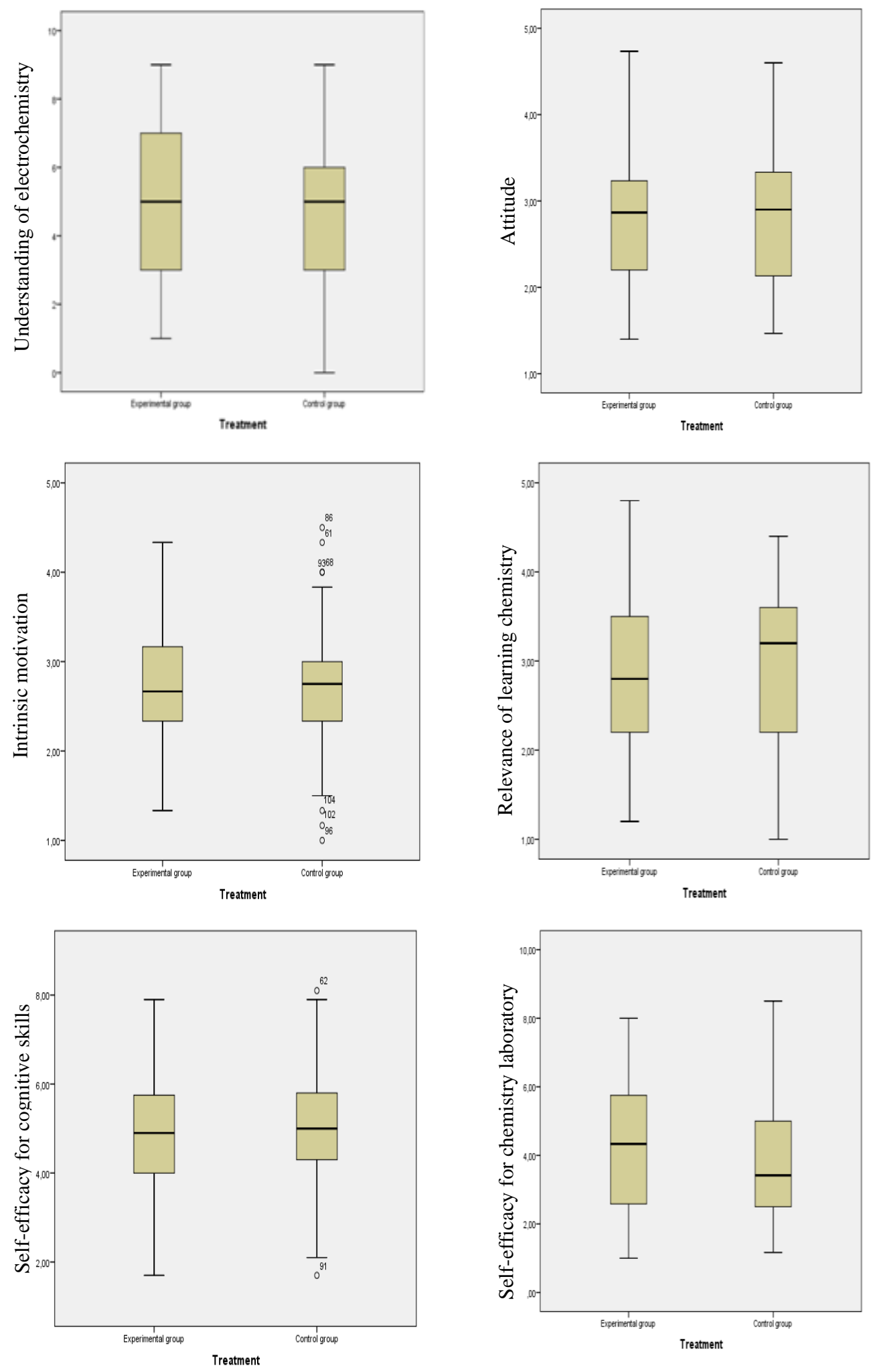

Figure 3 Box plots for each dependent variable 
Regarding multivariate outliers, the Mahalanobis distance was checked whether the data contained multivariate outliers. Since it (10.89) was smaller than the critical value (22.46) it was concluded that there weren't multivariate outliers in the data file (Tabackhnick \& Fidell, 2007).

\subsubsection{Checking the Assumptions of MANOVA for the Pre-test Scores} Assumptions of MANOVA are normality, linearity, multicollinearity and singularity, and homogeneity of variance-covariance matrices. Normality assumption involves both univariate and multivariate normality. Univariate normality assumption refers that the observations should be normally distributed in each group. For assessing univariate normality, skewness and kurtosis values for each dependent variable in each group are calculated. While value of skewness measures the symmetry, kurtosis value measures peakedness of the distribution relative to a normal distribution. By statistical convention, skewness and kurtosis values should fall in the range from +1 to -1 if data are normally distributed (Wegner, 2007). The values between +2 and -2 are also acceptable in many cases (Cameron, 2004). Multivariate normality assumption is related to distribution of the joint effect of two or more variables. To check multivariate normality, Mahalanobis distance is calculated through Regression analysis with SPSS. "Mahalanobis distance is the distance of a case from the centroid of the remaining cases, where the centroid is the point created at the intersection of the means of all variables" (Tabachnick \& Fidell, 2007, p. 74). It can be evaluated using the chi-square $\left(\mathrm{X}^{2}\right)$ distribution. If this value is larger than the critical $X^{2}$ value at $\alpha=.001$ for the number of dependent variables, this assumption is met (Tabachnick \& Fidell, 2007).

Linearity assumption refers to the existence of a straight-line relationship between each pair of dependent variables (Tabachnick \& Fidell, 2007). To check the linearity assumption, scatter plots between each pair of dependent variables are generated for each group separately. Multicollinearity means that the dependent variables are too highly correlated (i.e., .90 and 
above). To check the assumption of multicollinearity, correlation analysis is run. Singularity refers that one of the dependent variables is a combination of two or more of the other variables (Tabachnick \& Fidell, 2007). For MANOVA, multicollinearity and singularity create statistical problems.

In MANOVA, homogeneity of variance-covariance matrices implies that "variance covariance matrices within each cell of the design are sampled from the same population variance-covariance matrix" (Tabachnick \& Fidell, 2007, pp. 251-252). For testing the equivalence of variance- covariance matrices, Box's M statistics is used. A non-significant result $(p>.001)$ for F test from Box's M statistics indicates that this assumption is met (Tabachnick \& Fidell, 2007).

In the present study, before running MANOVA, both univariate and multivariate normality assumptions were checked. For univariate normality, it was checked that whether the observations were normally distributed on the dependent variables in each group. Descriptive statistics including skewness and kurtosis values are displayed in Table 8. For the experimental group, skewness values range from -.05 to .36 for understanding of electrochemistry, attitude, intrinsic motivation, relevance of learning chemistry to personal goals, chemistry self-efficacy for cognitive skills, and self-efficacy for chemistry laboratory. On the other hand, kurtosis values range from -1.16 to -.07 for all dependent variables. For the control group, skewness and kurtosis values range from -.40 to .75 and from -.92 to .41 for all dependent variables, respectively. As a result, skewness and kurtosis values are in acceptable ranges $(-2,+2)$ for a normal distribution. 
Table 8 Descriptive Statistics for Pre-tests Scores

\begin{tabular}{|c|c|c|c|c|c|}
\hline & Treatment & & & Statistic & $\begin{array}{l}\text { Std. } \\
\text { Error }\end{array}$ \\
\hline Understanding & Experimental & Mean & & 4.58 & .306 \\
\hline of & group & $95 \%$ Confidence & Lower & 306 & \\
\hline Electrochemistry & & Interval for Mean & Bound & 3.90 & \\
\hline & & & Upper & 5.19 & \\
\hline & & $5 \%$ Trimmed Mean & & 4.55 & \\
\hline & & Median & & 5.00 & \\
\hline & & Variance & & 5.524 & \\
\hline & & Std. Deviation & & 2.350 & \\
\hline & & Minimum & & 1 & \\
\hline & & Maximum & & 9 & \\
\hline & & Range & & 8 & \\
\hline & & Interquartile Range & & 4 & \\
\hline & & Skewness & & .029 & .311 \\
\hline & & Kurtosis & & -1.157 & .613 \\
\hline & Control & Mean & & 4.44 & .336 \\
\hline & group & $95 \%$ Confidence & Lower & 377 & \\
\hline & & Interval for Mean & Bound & 3.11 & \\
\hline & & & $\begin{array}{l}\text { Upper } \\
\text { Bound }\end{array}$ & 5.12 & \\
\hline & & $5 \%$ Trimmed Mean & & 4.45 & \\
\hline & & Median & & 5.00 & \\
\hline & & Variance & & 6.101 & \\
\hline & & Std. Deviation & & 2.470 & \\
\hline & & Minimum & & 0 & \\
\hline & & Maximum & & 9 & \\
\hline & & Range & & 9 & \\
\hline & & Interquartile Range & & 3 & \\
\hline & & Skewness & & -.177 & .325 \\
\hline & & Kurtosis & & -.917 & .639 \\
\hline
\end{tabular}


Table 8 Descriptive Statistics for Pre-tests Scores (continued)

\begin{tabular}{|c|c|c|c|c|c|}
\hline & Treatment & & & Statistic & $\begin{array}{l}\text { Std. } \\
\text { Error }\end{array}$ \\
\hline \multirow[t]{28}{*}{ Attitude } & \multirow{14}{*}{$\begin{array}{l}\text { Experimental } \\
\text { group }\end{array}$} & Mean & & 2.8201 & .09756 \\
\hline & & 95\% Confidence & Lower & 26249 & \\
\hline & & Interval for Mean & Bound & 2.0249 & \\
\hline & & & $\begin{array}{l}\text { Upper } \\
\text { Bound }\end{array}$ & 3.0154 & \\
\hline & & $5 \%$ Trimmed Mean & & 2.7998 & \\
\hline & & Median & & 2.8667 & \\
\hline & & Variance & & .562 & \\
\hline & & Std. Deviation & & .74935 & \\
\hline & & Minimum & & 1.40 & \\
\hline & & Maximum & & 4.73 & \\
\hline & & Range & & 3.33 & \\
\hline & & Interquartile Range & & 1.07 & \\
\hline & & Skewness & & .351 & .311 \\
\hline & & Kurtosis & & -.072 & .613 \\
\hline & \multirow{14}{*}{$\begin{array}{l}\text { Control } \\
\text { group }\end{array}$} & Mean & \multirow{14}{*}{$\begin{array}{l}\text { Lower } \\
\text { Bound } \\
\text { Upper } \\
\text { Bound }\end{array}$} & 2.8418 & .10131 \\
\hline & & 95\% Confidence & & 26385 & \\
\hline & & Interval for Mean & & & \\
\hline & & & & 3.0450 & \\
\hline & & $5 \%$ Trimmed Mean & & 2.8253 & \\
\hline & & Median & & 2.9000 & \\
\hline & & Variance & & .554 & \\
\hline & & Std. Deviation & & .74450 & \\
\hline & & Minimum & & 1.47 & \\
\hline & & Maximum & & 4.60 & \\
\hline & & Range & & 3.13 & \\
\hline & & Interquartile Range & & 1.25 & \\
\hline & & Skewness & & .169 & .325 \\
\hline & & Kurtosis & & -.676 & 639 \\
\hline
\end{tabular}


Table 8 Descriptive Statistics for Pre-tests Scores (continued)

\begin{tabular}{|c|c|c|c|c|c|}
\hline & Treatment & & & Statistic & $\begin{array}{c}\text { Std. } \\
\text { Error }\end{array}$ \\
\hline \multirow{28}{*}{$\begin{array}{l}\text { Intrinsic } \\
\text { motivation }\end{array}$} & \multirow{14}{*}{$\begin{array}{l}\text { Experimental } \\
\text { group }\end{array}$} & Mean & & 2.6860 & .08995 \\
\hline & & $95 \%$ Confidence & Lower & 2.5059 & \\
\hline & & Interval for Mean & Bound & & \\
\hline & & & $\begin{array}{l}\text { Upper } \\
\text { Bound }\end{array}$ & 2.8661 & \\
\hline & & $5 \%$ Trimmed Mean & & 2.6745 & \\
\hline & & Median & & 2.6667 & \\
\hline & & Variance & & .477 & \\
\hline & & Std. Deviation & & 69094 & \\
\hline & & Minimum & & 1.33 & \\
\hline & & Maximum & & 4.33 & \\
\hline & & Range & & 3.00 & \\
\hline & & Interquartile Range & & .83 & \\
\hline & & Skewness & & .231 & .311 \\
\hline & & Kurtosis & & -.097 & .613 \\
\hline & \multirow{14}{*}{$\begin{array}{l}\text { Control } \\
\text { group }\end{array}$} & Mean & \multirow{14}{*}{$\begin{array}{l}\text { Lower } \\
\text { Bound } \\
\text { Upper } \\
\text { Bound }\end{array}$} & 2.6728 & .10379 \\
\hline & & 95\% Confidence & & 2.4647 & \\
\hline & & Interval for Mean & & & \\
\hline & & & & 2.8810 & \\
\hline & & $5 \%$ Trimmed Mean & & 2.6667 & \\
\hline & & Median & & 2.7500 & \\
\hline & & Variance & & .582 & \\
\hline & & Std. Deviation & & .76271 & \\
\hline & & Minimum & & 1.00 & \\
\hline & & Maximum & & 4.50 & \\
\hline & & Range & & 3.50 & \\
\hline & & Interquartile Range & & .71 & \\
\hline & & Skewness & & .115 & .325 \\
\hline & & Kurtosis & & .088 & .639 \\
\hline
\end{tabular}


Table 8 Descriptive Statistics for Pre-tests Scores (continued)

\begin{tabular}{|c|c|c|c|c|c|}
\hline & Treatment & & & Statistic & $\begin{array}{l}\text { Std. } \\
\text { Error }\end{array}$ \\
\hline \multirow{28}{*}{$\begin{array}{l}\text { Relevance of } \\
\text { learning } \\
\text { chemistry to } \\
\text { personal goals }\end{array}$} & \multirow{14}{*}{$\begin{array}{l}\text { Experimental } \\
\text { group }\end{array}$} & Mean & \multirow{14}{*}{$\begin{array}{l}\text { Lower } \\
\text { Bound } \\
\text { Upper } \\
\text { Bound }\end{array}$} & 2.8940 & .11568 \\
\hline & & $95 \%$ Confidence & & 26624 & \\
\hline & & Interval for Mean & & & \\
\hline & & & & 3.1255 & \\
\hline & & $5 \%$ Trimmed Mean & & 2.8822 & \\
\hline & & Median & & 2.8000 & \\
\hline & & Variance & & .790 & \\
\hline & & Std. Deviation & & .88855 & \\
\hline & & Minimum & & 1.20 & \\
\hline & & Maximum & & 4.80 & \\
\hline & & Range & & 3.60 & \\
\hline & & Interquartile Range & & 1.40 & \\
\hline & & Skewness & & .195 & .311 \\
\hline & & Kurtosis & & -.644 & .613 \\
\hline & \multirow{14}{*}{$\begin{array}{l}\text { Control } \\
\text { group }\end{array}$} & Mean & \multirow{14}{*}{$\begin{array}{l}\text { Lower } \\
\text { Bound } \\
\text { Upper } \\
\text { Bound }\end{array}$} & 2.9472 & .12199 \\
\hline & & $95 \%$ Confidence & & 27025 & \\
\hline & & Interval for Mean & & & \\
\hline & & & & 3.1918 & \\
\hline & & $5 \%$ Trimmed Mean & & 2.9717 & \\
\hline & & Median & & 3.2000 & \\
\hline & & Variance & & .804 & \\
\hline & & Std. Deviation & & .89645 & \\
\hline & & Minimum & & 1.00 & \\
\hline & & Maximum & & 4.40 & \\
\hline & & Range & & 3.40 & \\
\hline & & Interquartile Range & & 1.45 & \\
\hline & & Skewness & & -.400 & .325 \\
\hline & & Kurtosis & & -.764 & 639 \\
\hline
\end{tabular}


Table 8 Descriptive Statistics for Pre-tests Scores (continued)

\begin{tabular}{|c|c|c|c|c|c|}
\hline & Treatment & & & Statistic & $\begin{array}{c}\text { Std. } \\
\text { Error }\end{array}$ \\
\hline Chemistry self- & Experimental & Mean & & 4.9473 & .16802 \\
\hline efficacy for & group & 95\% Confidence & Lower & 4.6110 & \\
\hline & & Interval for Mean & Bound & & \\
\hline & & & $\begin{array}{l}\text { Upper } \\
\text { Bound }\end{array}$ & 5.2836 & \\
\hline & & $5 \%$ Trimmed Mean & & 4.9422 & \\
\hline & & Median & & 4.9000 & \\
\hline & & Variance & & 1.666 & \\
\hline & & Std. Deviation & & 1.29060 & \\
\hline & & Minimum & & 1.70 & \\
\hline & & Maximum & & 7.90 & \\
\hline & & Range & & 6.20 & \\
\hline & & Interquartile Range & & 1.80 & \\
\hline & & Skewness & & .019 & .311 \\
\hline & & Kurtosis & & -.117 & .613 \\
\hline & Control & Mean & & 4.8918 & .18105 \\
\hline & group & 95\% Confidence & Lower & 4.5287 & \\
\hline & & Interval for Mean & Bound & & \\
\hline & & & $\begin{array}{l}\text { Upper } \\
\text { Bound }\end{array}$ & 5.2550 & \\
\hline & & $5 \%$ Trimmed Mean & & 4.8897 & \\
\hline & & Median & & 5.0000 & \\
\hline & & Variance & & 1.770 & \\
\hline & & Std. Deviation & & 1.33041 & \\
\hline & & Minimum & & 1.70 & \\
\hline & & Maximum & & 8.10 & \\
\hline & & Range & & 6.40 & \\
\hline & & Interquartile Range & & 1.59 & \\
\hline & & Skewness & & -.159 & .325 \\
\hline & & Kurtosis & & .409 & .639 \\
\hline
\end{tabular}


Table 8 Descriptive Statistics for Pre-tests Scores (continued)

\begin{tabular}{|c|c|c|c|c|c|}
\hline & Treatment & & & Statistic & $\begin{array}{l}\text { Std. } \\
\text { Error }\end{array}$ \\
\hline \multirow{28}{*}{$\begin{array}{l}\text { Self-efficacy for } \\
\text { chemistry } \\
\text { laboratory }\end{array}$} & \multirow{14}{*}{$\begin{array}{l}\text { Experimental } \\
\text { group }\end{array}$} & Mean & \multirow{14}{*}{$\begin{array}{l}\text { Lower } \\
\text { Bound } \\
\text { Upper } \\
\text { Bound }\end{array}$} & 4.1634 & .24864 \\
\hline & & $95 \%$ Confidence & & 36657 & \\
\hline & & Interval for Mean & & / & \\
\hline & & & & 4.6611 & \\
\hline & & $5 \%$ Trimmed Mean & & 4.1471 & \\
\hline & & Median & & 4.3333 & \\
\hline & & Variance & & 3.647 & \\
\hline & & Std. Deviation & & 1.90982 & \\
\hline & & Minimum & & 1.00 & \\
\hline & & Maximum & & 8.00 & \\
\hline & & Range & & 7.00 & \\
\hline & & Interquartile Range & & 3.33 & \\
\hline & & Skewness & & -.088 & .311 \\
\hline & & Kurtosis & & -.935 & .613 \\
\hline & \multirow{14}{*}{$\begin{array}{l}\text { Control } \\
\text { group }\end{array}$} & Mean & \multirow{14}{*}{$\begin{array}{l}\text { Lower } \\
\text { Bound } \\
\text { Upper } \\
\text { Bound }\end{array}$} & 3.7160 & .24691 \\
\hline & & $95 \%$ Confidence & & 32208 & \\
\hline & & Interval for Mean & & & \\
\hline & & & & 4.2113 & \\
\hline & & $5 \%$ Trimmed Mean & & 3.6094 & \\
\hline & & Median & & 3.4167 & \\
\hline & & Variance & & 3.292 & \\
\hline & & Std. Deviation & & 1.81440 & \\
\hline & & Minimum & & 1.17 & \\
\hline & & Maximum & & 8.50 & \\
\hline & & Range & & 7.33 & \\
\hline & & Interquartile Range & & 2.58 & \\
\hline & & Skewness & & .744 & .325 \\
\hline & & Kurtosis & & .181 & .639 \\
\hline
\end{tabular}

For multivariate normality, Mahalanobis distance was calculated as 10.89 through Regression analysis with SPSS. Taking the number of dependent variables as six, critical value obtained using a chi-square critical value table is 22.46 at $\alpha=.001$ (Tabachnick \& Fidell, 2007). Since the Mahalanobis distance value (10.89) is smaller than the critical value (22.46) the multivariate normality assumption was met. 
To check the linearity assumption, scatter plots between each pair of dependent variables were generated for treatment groups (experimental and control groups) separately. No evidence of non-linearity was observed from the scatterplots. Therefore, assumption of linearity was satisfied.

For singularity, I ensured that sub-dimensions of the scales (e.g. intrinsic motivation and relevance of learning chemistry to personal goals) were not used with total scores of the scales (e.g. motivation). To check the assumption of multicollinearity, correlation analysis was run. Correlations among the dependent variables were displayed in Table 9. It appeared that none of the correlation coefficient exceeded the value of .90; therefore, there were not too highly correlated variables and the assumption was not violated.

Table 9 Correlations among the dependent variables for the pre-test scores

\begin{tabular}{lrrrrrr}
\hline & 1 & 2 & 3 & 4 & 5 & 6 \\
\hline 1. Understanding of electrochemistry & 1 & & & & & \\
2. Attitude toward chemistry & .155 & 1 & & & & \\
3. Relevance of learning chemistry & -.054 & -.673 & 1 & & & \\
4. Intrinsic motivation & .007 & -.484 & .521 & 1 & & \\
5. Self-efficacy for cognitive skills & -.017 & -.421 & .394 & .299 & 1 & \\
$\begin{array}{l}\text { 6. Self-efficacy for chemistry } \\
\text { laboratory }\end{array}$ & -.103 & -.219 & .260 & .340 & .420 & 1 \\
\hline
\end{tabular}

Regarding the homogeneity of variance-covariance matrices assumption, Box's Test was run. The Box's M Test of Equality of Covariance Matrices presented in Table 10 was not statistically significant (Box's $M=$ $23.285, F=1.045, p>.001)$, indicating that the dependent variable covariance matrices were equal across the treatment groups.

Table 10 Box's M Test of Equality of Covariance Matrices

\begin{tabular}{lr}
\hline Box's M & 23.285 \\
F & 1.045 \\
df1 & 21 \\
df2 & 44558.890 \\
Sig. & .403 \\
\hline
\end{tabular}




\subsubsection{Results of MANOVA for the Pre-test Scores}

Having met all assumptions of the MANOVA, one-way MANOVA was run to investigate whether there was a significant mean difference between groups with respect to students' understanding of electrochemistry, attitude, intrinsic motivation, relevance of learning chemistry to personal goals, selfefficacy for cognitive skills and chemistry laboratory before the treatment. Results obtained from the analysis are displayed in Table 11.

Table 11 Results of one-way MANOVA for pre-test scores

\begin{tabular}{|c|c|c|c|c|c|c|c|}
\hline Effect & & $\mathrm{F}$ & $\mathrm{df}$ & Error $\mathrm{df}$ & Sig. & $\begin{array}{l}\text { Partial } \\
\text { Eta } \\
\text { Squared }\end{array}$ & $\begin{array}{c}\text { Observed } \\
\text { Power }\end{array}$ \\
\hline \multirow[t]{4}{*}{ Intercept } & Pillai's Trace & 2092.55 & 6 & 106 & .000 & .992 & 1.000 \\
\hline & Wilks' Lambda & 2092.55 & 6 & 106 & .000 & .992 & 1.000 \\
\hline & Hotelling's Trace & 2092.55 & 6 & 106 & .000 & .992 & 1.000 \\
\hline & Roy's Largest Root & 2092.55 & 6 & 106 & .000 & .992 & 1.000 \\
\hline \multirow[t]{4}{*}{ Treatment } & Pillai's Trace & .44 & 6 & 106 & .854 & .024 & .173 \\
\hline & Wilks' Lambda & .44 & 6 & 106 & .854 & .024 & .173 \\
\hline & Hotelling's Trace & .44 & 6 & 106 & .854 & .024 & .173 \\
\hline & Roy's Largest Root & .44 & 6 & 106 & .854 & .024 & .173 \\
\hline
\end{tabular}

Results indicated that there was no statistically significant mean difference between the experimental and control groups with respect to the combined dependent variables of understanding of electrochemistry, attitude, intrinsic motivation, relevance of learning chemistry to personal goals, selfefficacy for cognitive skills and chemistry laboratory before the treatment: $F(6$, $106)=.44, p>.05 ;$ Wilks' Lambda $=.98$. In addition, the between-subjects effects were examined by the follow-up analysis of variance (ANOVA), after the data satisfied the assumption of equality of variances. The results of ANOVA revealed that there was also no statistically significant mean difference between experimental and the control groups in terms of each dependent variable (see Table 12). 
Table 12 Result of univarite tests for the between-subject effects of one-way MANOVA for the pre-tests scores

\begin{tabular}{|c|c|c|c|c|c|c|c|c|c|}
\hline Source & Dependent Variable & $\begin{array}{l}\text { Type III } \\
\text { Sum of } \\
\text { Squares }\end{array}$ & $\mathrm{df}$ & & $\begin{array}{l}\text { Mean } \\
\text { Square }\end{array}$ & $\mathrm{F}$ & Sig. & $\begin{array}{c}\text { Partial Eta } \\
\text { Squared }\end{array}$ & $\begin{array}{l}\text { Observed } \\
\text { Power }\end{array}$ \\
\hline \multirow[t]{6}{*}{$\begin{array}{l}\text { Corrected } \\
\text { Model }\end{array}$} & $\begin{array}{l}\text { Understanding of } \\
\text { electrochemistry }\end{array}$ & .490 & & 1 & .490 & .084 & .772 & .001 & .060 \\
\hline & Attitude & .013 & & 1 & .013 & .024 & .878 & .000 & .053 \\
\hline & Intrinsic motivation & .005 & & 1 & .005 & .009 & .923 & .000 & .051 \\
\hline & Relevance of learning chemistry & .080 & & 1 & .080 & .100 & .752 & .001 & .061 \\
\hline & Self-efficacy for cognitive skills & .087 & & 1 & .087 & .051 & .822 & .000 & .056 \\
\hline & $\begin{array}{l}\text { Self-efficacy for chemistry } \\
\text { laboratory }\end{array}$ & 5.641 & & 1 & 5.641 & 1.622 & .205 & .014 & .243 \\
\hline \multirow[t]{6}{*}{ Intercept } & $\begin{array}{l}\text { Understanding of } \\
\text { electrochemistry }\end{array}$ & 2294.295 & & 1 & 2294.295 & 395.605 & .000 & .781 & 1.000 \\
\hline & Attitude & 903.838 & & 1 & 903.838 & 1619.599 & .000 & .936 & 1.000 \\
\hline & Intrinsic motivation & 809.672 & & 1 & 809.672 & 1535.766 & .000 & .933 & 1.000 \\
\hline & Relevance of learning chemistry & 961.978 & & 1 & 961.978 & 1208.129 & .000 & .916 & 1.000 \\
\hline & Self-efficacy for cognitive skills & 2729.482 & & 1 & 2729.482 & 1591.096 & .000 & .935 & 1.000 \\
\hline & $\begin{array}{l}\text { Self-efficacy for chemistry } \\
\text { laboratory }\end{array}$ & 1750.469 & & 1 & 1750.469 & 503.335 & .000 & .819 & 1.000 \\
\hline
\end{tabular}


Table 12 Result of univarite tests for the between-subject effects of one-way MANOVA for the pre-tests scores (continued)

\begin{tabular}{|c|c|c|c|c|c|c|c|c|}
\hline Source & Dependent Variable & $\begin{array}{l}\text { Type III } \\
\text { Sum of } \\
\text { Squares }\end{array}$ & df & $\begin{array}{l}\text { Mean } \\
\text { Square }\end{array}$ & $\mathrm{F}$ & Sig. & $\begin{array}{l}\text { Partial Eta } \\
\text { Squared }\end{array}$ & $\begin{array}{l}\text { Observed } \\
\text { Power }\end{array}$ \\
\hline \multirow[t]{6}{*}{ Treatment } & $\begin{array}{l}\text { Understanding of } \\
\text { electrochemistry }\end{array}$ & .490 & 1 & .490 & .084 & .772 & .001 & .060 \\
\hline & Attitude & .013 & 1 & .013 & .024 & .878 & .000 & .053 \\
\hline & Intrinsic motivation & .005 & 1 & .005 & .009 & .923 & .000 & .051 \\
\hline & Relevance of learning chemistry & .080 & 1 & .080 & .100 & .752 & .001 & .061 \\
\hline & Self-efficacy for cognitive skills & .087 & 1 & .087 & .051 & .822 & .000 & .056 \\
\hline & $\begin{array}{l}\text { Self-efficacy for chemistry } \\
\text { laboratory }\end{array}$ & 5.641 & 1 & 5.641 & 1.622 & .205 & .014 & .243 \\
\hline \multirow[t]{6}{*}{ Error } & $\begin{array}{l}\text { Understanding of } \\
\text { electrochemistry }\end{array}$ & 643.740 & 111 & 5.799 & & & & \\
\hline & Attitude & 61.945 & 111 & .558 & & & & \\
\hline & Intrinsic motivation & 58.520 & 111 & .527 & & & & \\
\hline & Relevance of learning chemistry & 88.384 & 111 & .796 & & & & \\
\hline & Self-efficacy for cognitive skills & 190.417 & 111 & 1.715 & & & & \\
\hline & $\begin{array}{l}\text { Self-efficacy for chemistry } \\
\text { laboratory }\end{array}$ & 386.029 & 111 & 3.478 & & & & \\
\hline
\end{tabular}


Table 12 Result of univarite tests for the between-subject effects of one-way MANOVA for the pre-tests scores (continued)

\begin{tabular}{|c|c|c|c|c|c|c|c|c|}
\hline Source & Dependent Variable & $\begin{array}{l}\text { Type III } \\
\text { Sum of } \\
\text { Squares } \\
\end{array}$ & df & $\begin{array}{l}\text { Mean } \\
\text { Square }\end{array}$ & $\mathrm{F}$ & Sig. & $\begin{array}{c}\text { Partial Eta } \\
\text { Squared }\end{array}$ & $\begin{array}{c}\text { Observed } \\
\text { Power }\end{array}$ \\
\hline \multirow[t]{6}{*}{ Total } & $\begin{array}{l}\text { Understanding of } \\
\text { electrochemistry }\end{array}$ & 2946.000 & 113 & & & & & \\
\hline & Attitude & 967.264 & 113 & & & & & \\
\hline & Intrinsic motivation & 869.962 & 113 & & & & & \\
\hline & Relevance of learning chemistry & 1051.552 & 113 & & & & & \\
\hline & Self-efficacy for cognitive skills & 2926.705 & 113 & & & & & \\
\hline & $\begin{array}{l}\text { Self-efficacy for chemistry } \\
\text { laboratory }\end{array}$ & 2154.395 & 113 & & & & & \\
\hline \multirow[t]{6}{*}{ Corrected Total } & $\begin{array}{l}\text { Understanding of } \\
\text { electrochemistry }\end{array}$ & 644.230 & 112 & & & & & \\
\hline & Attitude & 61.958 & 112 & & & & & \\
\hline & Intrinsic motivation & 58.525 & 112 & & & & & \\
\hline & Relevance of learning chemistry & 88.464 & 112 & & & & & \\
\hline & Self-efficacy for cognitive skills & 190.504 & 112 & & & & & \\
\hline & $\begin{array}{l}\text { Self-efficacy for chemistry } \\
\text { laboratory }\end{array}$ & 391.670 & 112 & & & & & \\
\hline
\end{tabular}




\subsection{Analyses of the Post-tests Scores}

\subsubsection{Preliminary Analyses}

Before performing the MANOVA, both univariate and multivariate outliers were checked for the post-test scores. Regarding univariate outliers, the box plots for each dependent variable indicated that there were not any extreme points in the data file. However, there were one and two outliers in the box plots for attitude and relevance of learning chemistry to personal goals, respectively (see Figure 4). Since original means and the 5\% trimmed means for these dependent variables are very similar for the pre-test scores (see Table 13), it was concluded that outliers did not have important influence on the mean. Therefore, these outliers remained in the data file. 

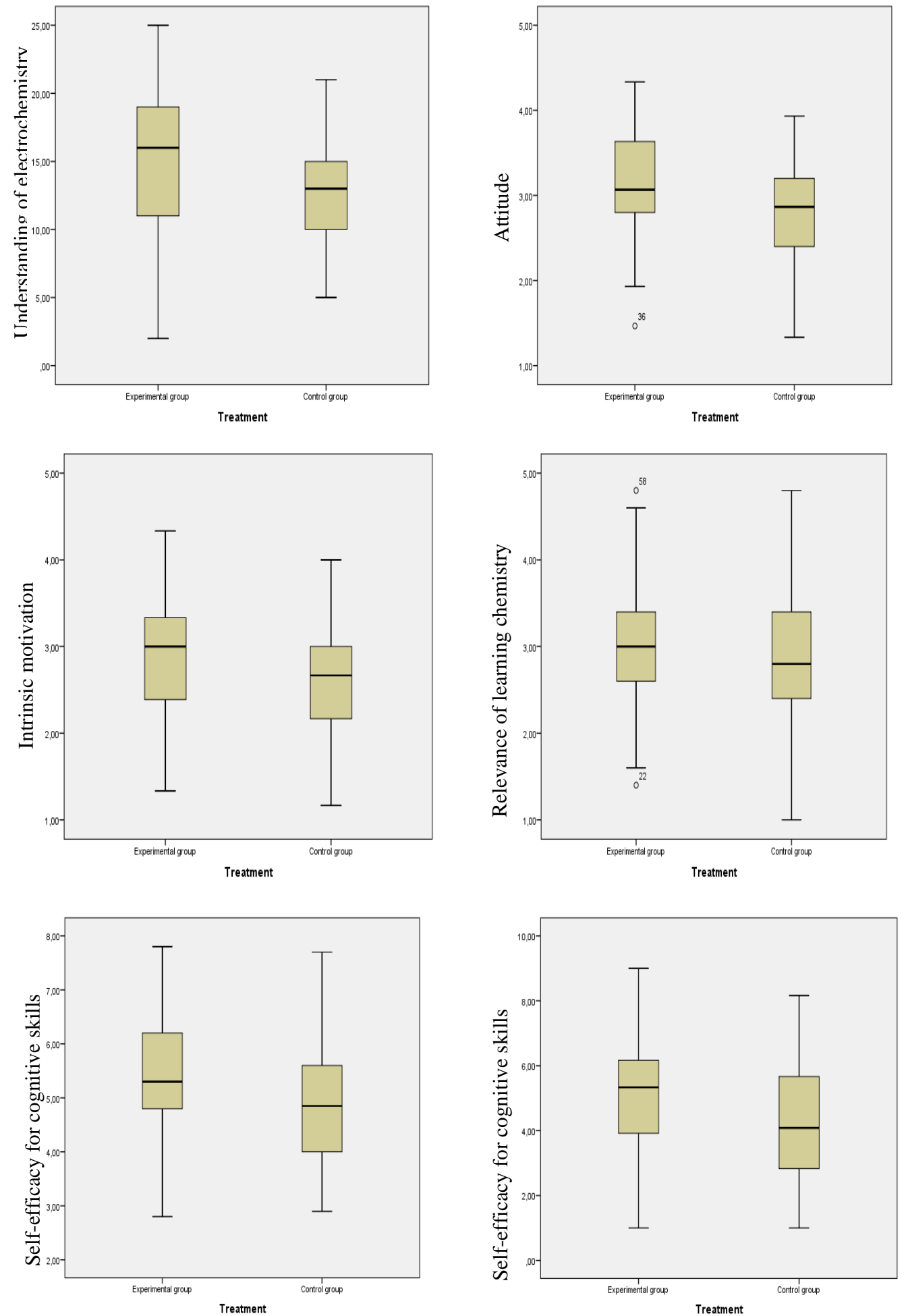

Figure 4 Box plots for each dependent variable 
The Mahalanobis distance value was calculated to check whether data included multivariate outliers. It was 18.21 which is smaller than the critical value (22.46); thus, it was concluded that there weren't multivariate outliers in the data file (Tabackhnick \& Fidell, 2007).

\subsubsection{Checking Assumptions of MANOVA for the Post-test Scores}

Before the analysis of post-test scores, the assumptions of MANOVA which are normality, linearity, multicollinearity and singularity, and homogeneity of variance-covariance matrices were tested. For the experimental group, skewness values range from -.41to .76 for understanding of electrochemistry, attitude, intrinsic motivation, relevance of learning chemistry to personal goals, self-efficacy for cognitive skills and chemistry laboratory while kurtosis vales range from -.63 to .00 for all dependent variables. The skewness values were found to be between -.35 and .33; and kurtosis values were between -.83 and .36 for all dependent variables for the control group. As a result, skewness and kurtosis values are in acceptable ranges $(-1,+1)$ for a normal distribution. Descriptive statistics including skewness and kurtosis values are displayed in Table 13. 
Table 13 Descriptive Statistics for Post-tests Scores

\begin{tabular}{|c|c|c|c|c|c|}
\hline & Treatment & & & Statistic & $\begin{array}{c}\text { Std. } \\
\text { Error }\end{array}$ \\
\hline \multirow{28}{*}{$\begin{array}{l}\text { Understanding } \\
\text { of } \\
\text { electrochemistry }\end{array}$} & \multirow{14}{*}{$\begin{array}{l}\text { Experimental } \\
\text { group }\end{array}$} & Mean & \multirow{14}{*}{$\begin{array}{l}\text { Lower } \\
\text { Bound } \\
\text { Upper } \\
\text { Bound }\end{array}$} & 15.2712 & .64591 \\
\hline & & $95 \%$ Confidence & & 139783 & \\
\hline & & Interval for Mean & & $13.9 / 83$ & \\
\hline & & & & 16.5641 & \\
\hline & & 5\% Trimmed Mean & & 15.3032 & \\
\hline & & Median & & 16.0000 & \\
\hline & & Variance & & 24.615 & \\
\hline & & Std. Deviation & & 4.96134 & \\
\hline & & Minimum & & 2.00 & \\
\hline & & Maximum & & 25.00 & \\
\hline & & Range & & 23.00 & \\
\hline & & Interquartile Range & & 8.00 & \\
\hline & & Skewness & & -.090 & .311 \\
\hline & & Kurtosis & & -.624 & .613 \\
\hline & \multirow{14}{*}{$\begin{array}{l}\text { Control } \\
\text { group }\end{array}$} & Mean & \multirow{14}{*}{$\begin{array}{l}\text { Lower } \\
\text { Bound } \\
\text { Upper } \\
\text { Bound }\end{array}$} & 12.9630 & .47654 \\
\hline & & $95 \%$ Confidence & & 120071 & \\
\hline & & Interval for Mean & & $12.00 / 1$ & \\
\hline & & & & 13.9188 & \\
\hline & & $5 \%$ Trimmed Mean & & 12.9938 & \\
\hline & & Median & & 13.0000 & \\
\hline & & Variance & & 12.263 & \\
\hline & & Std. Deviation & & 3.50182 & \\
\hline & & Minimum & & 5.00 & \\
\hline & & Maximum & & 21.00 & \\
\hline & & Range & & 16.00 & \\
\hline & & Interquartile Range & & 525 & \\
\hline & & Skewness & & -.157 & .325 \\
\hline & & Kurtosis & & -.637 & 639 \\
\hline
\end{tabular}


Table 13 Descriptive Statistics for Post-tests Scores (continued)

\begin{tabular}{|c|c|c|c|c|c|}
\hline & Treatment & & & Statistic & $\begin{array}{l}\text { Std. } \\
\text { Error }\end{array}$ \\
\hline \multirow[t]{28}{*}{ Attitude } & \multirow{14}{*}{$\begin{array}{l}\text { Experimental } \\
\text { group }\end{array}$} & Mean & \multirow{14}{*}{$\begin{array}{l}\text { Lower } \\
\text { Bound } \\
\text { Upper } \\
\text { Bound }\end{array}$} & 3.1677 & .08019 \\
\hline & & $95 \%$ Confidence & & 30072 & \\
\hline & & Interval for Mean & & $3.00 / 2$ & \\
\hline & & & & 3.3282 & \\
\hline & & $5 \%$ Trimmed Mean & & 3.1792 & \\
\hline & & Median & & 3.0667 & \\
\hline & & Variance & & .379 & \\
\hline & & Std. Deviation & & .61594 & \\
\hline & & Minimum & & 1.47 & \\
\hline & & Maximum & & 4.33 & \\
\hline & & Range & & 2.87 & \\
\hline & & Interquartile Range & & .87 & \\
\hline & & Skewness & & -.146 & .311 \\
\hline & & Kurtosis & & -.295 & .613 \\
\hline & \multirow{14}{*}{$\begin{array}{l}\text { Control } \\
\text { group }\end{array}$} & Mean & \multirow{14}{*}{$\begin{array}{l}\text { Lower } \\
\text { Bound } \\
\text { Upper } \\
\text { Bound }\end{array}$} & 2.8433 & .08350 \\
\hline & & $95 \%$ Confidence & & 26758 & \\
\hline & & Interval for Mean & & & \\
\hline & & & & 3.0108 & \\
\hline & & $5 \%$ Trimmed Mean & & 2.8600 & \\
\hline & & Median & & 2.8667 & \\
\hline & & Variance & & .377 & \\
\hline & & Std. Deviation & & .61362 & \\
\hline & & Minimum & & 1.33 & \\
\hline & & Maximum & & 3.93 & \\
\hline & & Range & & 2.60 & \\
\hline & & Interquartile Range & & .82 & \\
\hline & & Skewness & & -.348 & .325 \\
\hline & & Kurtosis & & -.128 & .639 \\
\hline
\end{tabular}


Table 13 Descriptive Statistics for Post-tests Scores (continued)

\begin{tabular}{|c|c|c|c|c|c|}
\hline & Treatment & & & Statistic & $\begin{array}{l}\text { Std. } \\
\text { Error }\end{array}$ \\
\hline \multirow{28}{*}{$\begin{array}{l}\text { Intrinsic } \\
\text { motivation }\end{array}$} & \multirow{14}{*}{$\begin{array}{l}\text { Experimental } \\
\text { group }\end{array}$} & Mean & & 2.9570 & .08080 \\
\hline & & $95 \%$ Confidence & Lower & 2.7952 & \\
\hline & & Interval for Mean & Bound & 2.1952 & \\
\hline & & & $\begin{array}{l}\text { Upper } \\
\text { Bound }\end{array}$ & 3.1187 & \\
\hline & & $5 \%$ Trimmed Mean & & 2.9494 & \\
\hline & & Median & & 3.0000 & \\
\hline & & Variance & & .385 & \\
\hline & & Std. Deviation & & .62066 & \\
\hline & & Minimum & & 1.33 & \\
\hline & & Maximum & & 4.33 & \\
\hline & & Range & & 3.00 & \\
\hline & & Interquartile Range & & 1.00 & \\
\hline & & Skewness & & .009 & .311 \\
\hline & & Kurtosis & & -.259 & .613 \\
\hline & \multirow{14}{*}{$\begin{array}{l}\text { Control } \\
\text { group }\end{array}$} & Mean & \multirow{14}{*}{$\begin{array}{l}\text { Lower } \\
\text { Bound } \\
\text { Upper } \\
\text { Bound }\end{array}$} & 2.6142 & .08609 \\
\hline & & $95 \%$ Confidence & & 2.4415 & \\
\hline & & Interval for Mean & & $2.4+15$ & \\
\hline & & & & 2.7869 & \\
\hline & & $5 \%$ Trimmed Mean & & 2.6268 & \\
\hline & & Median & & 2.6667 & \\
\hline & & Variance & & .400 & \\
\hline & & Std. Deviation & & .63261 & \\
\hline & & Minimum & & 1.17 & \\
\hline & & Maximum & & 4.00 & \\
\hline & & Range & & 2.83 & \\
\hline & & Interquartile Range & & .83 & \\
\hline & & Skewness & & -.306 & .325 \\
\hline & & Kurtosis & & -.081 & .639 \\
\hline
\end{tabular}


Table 13 Descriptive Statistics for Post-tests Scores (continued)

\begin{tabular}{|c|c|c|c|c|c|}
\hline & Treatment & & & Statistic & $\begin{array}{l}\text { Std. } \\
\text { Error }\end{array}$ \\
\hline Relevance of & Experimental & Mean & & 3.0134 & .10009 \\
\hline learning & group & $95 \%$ Confidence & Lower & 28130 & \\
\hline chemistry to & & Interval for Mean & Bound & 2.0150 & \\
\hline personal goals & & & Upper & 3.2137 & \\
\hline & & 5\% Trimmed Mean & & 3.0038 & \\
\hline & & Median & & 3.0000 & \\
\hline & & Variance & & .591 & \\
\hline & & Std. Deviation & & .76880 & \\
\hline & & Minimum & & 1.40 & \\
\hline & & Maximum & & 4.80 & \\
\hline & & Range & & 3.40 & \\
\hline & & Interquartile Range & & .80 & \\
\hline & & Skewness & & .076 & .311 \\
\hline & & Kurtosis & & -.139 & .613 \\
\hline & Control & Mean & & 2.8296 & .11479 \\
\hline & group & $95 \%$ Confidence & Lower & 25994 & \\
\hline & & Interval for Mean & Bound & 2.5994 & \\
\hline & & & $\begin{array}{l}\text { Upper } \\
\text { Bound }\end{array}$ & 3.0599 & \\
\hline & & 5\% Trimmed Mean & & 2.8317 & \\
\hline & & Median & & 2.8000 & \\
\hline & & Variance & & .712 & \\
\hline & & Std. Deviation & & .84354 & \\
\hline & & Minimum & & 1.00 & \\
\hline & & Maximum & & 4.80 & \\
\hline & & Range & & 3.80 & \\
\hline & & Interquartile Range & & 1.00 & \\
\hline & & Skewness & & -.114 & .325 \\
\hline & & Kurtosis & & .359 & .639 \\
\hline
\end{tabular}


Table 13 Descriptive Statistics for Post-tests Scores (continued)

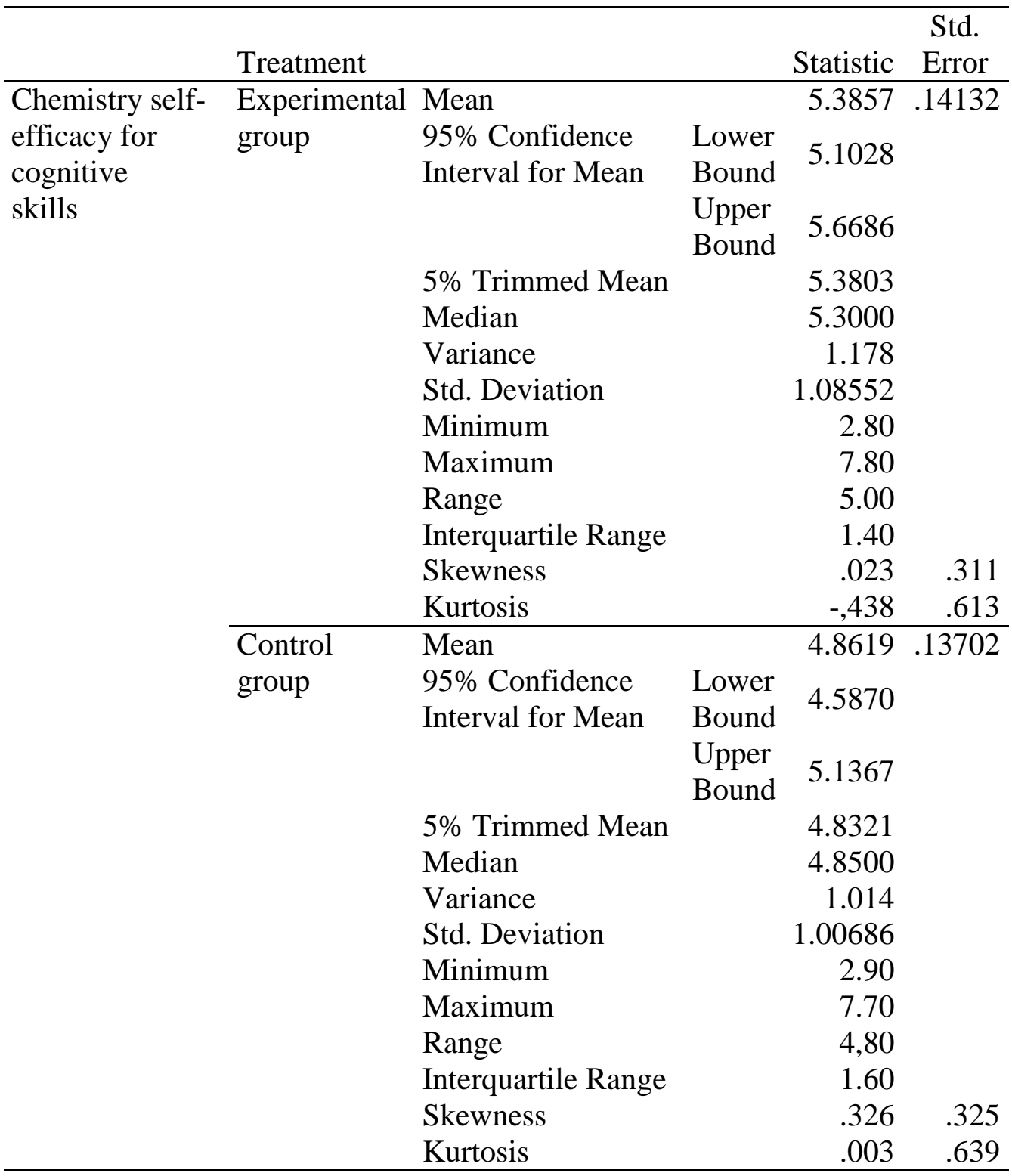


Table 13 Descriptive Statistics for Post-tests Scores (continued)

\begin{tabular}{|c|c|c|c|c|c|}
\hline & Treatment & & & Statistic & $\begin{array}{c}\text { Std. } \\
\text { Error }\end{array}$ \\
\hline \multirow{28}{*}{$\begin{array}{l}\text { Self-efficacy for } \\
\text { chemistry } \\
\text { laboratory }\end{array}$} & \multirow{14}{*}{$\begin{array}{l}\text { Experimental } \\
\text { group }\end{array}$} & Mean & \multirow{14}{*}{$\begin{array}{l}\text { Lower } \\
\text { Bound } \\
\text { Upper } \\
\text { Bound }\end{array}$} & 5.0474 & .23539 \\
\hline & & $95 \%$ Confidence & & 4.5763 & \\
\hline & & Interval for Mean & & & \\
\hline & & & & 5.5186 & \\
\hline & & $5 \%$ Trimmed Mean & & 5.0865 & \\
\hline & & Median & & 5.3333 & \\
\hline & & Variance & & 3.269 & \\
\hline & & Std. Deviation & & 1.80807 & \\
\hline & & Minimum & & 1.00 & \\
\hline & & Maximum & & 9.00 & \\
\hline & & Range & & 8.00 & \\
\hline & & Interquartile Range & & 2.33 & \\
\hline & & Skewness & & -.410 & .311 \\
\hline & & Kurtosis & & -.035 & .613 \\
\hline & \multirow{14}{*}{$\begin{array}{l}\text { Control } \\
\text { group }\end{array}$} & Mean & \multirow{14}{*}{$\begin{array}{l}\text { Lower } \\
\text { Bound } \\
\text { Upper } \\
\text { Bound }\end{array}$} & 4.1204 & .24457 \\
\hline & & $95 \%$ Confidence & & 36298 & \\
\hline & & Interval for Mean & & & \\
\hline & & & & 4.6109 & \\
\hline & & 5\% Trimmed Mean & & 4.1077 & \\
\hline & & Median & & 4.0833 & \\
\hline & & Variance & & 3.230 & \\
\hline & & Std. Deviation & & 1.79722 & \\
\hline & & Minimum & & 1.00 & \\
\hline & & Maximum & & 8.17 & \\
\hline & & Range & & 7.17 & \\
\hline & & Interquartile Range & & 2.92 & \\
\hline & & Skewness & & .037 & .325 \\
\hline & & Kurtosis & & -.823 & 639 \\
\hline
\end{tabular}

In order to test multivariate normality assumption for the post-test sores, Mahalanobis distance was calculated. It was found to be 18.21. With six dependent variables, critical value from a chi-square critical value table corresponds to 22.46 ( $\alpha=.001$, Tabachnick \& Fidell, 2007). Since the Mahalanobis distance value was higher than the critical value, the multivariate normality assumption was met. 
Due to the fact that the scatter plots between each pair of dependent variables for experimental and control group did not provide any evidence for non-linearity, it was concluded that assumption of linearity was satisfied.

Regarding another assumption, multicollinearity and singularity, first of all the total score of dimensions (e.g., motivation) was not used as a dependent variable along with the scores of their sub-dimensions (e.g. intrinsic motivation) in the analysis to meet singularity assumption. For multicollinearity, correlation coefficients among the dependent variables indicated that there were not too highly correlated variables (i.e., none of the correlation coefficient exceeded the value of .90); therefore, multicollinearity assumption was satisfied. Correlations among dependent variables are displayed in Table 14.

Table 14 Correlations among dependent variables for the post-test scores

\begin{tabular}{lrrrrrr}
\hline & 1 & 2 & 3 & 4 & 5 & 6 \\
\hline 1. Understanding of electrochemistry & 1 & & & & & \\
2. Attitude toward chemistry & .343 & 1 & & & & \\
3. Intrinsic motivation & .145 & .519 & 1 & & & \\
4. Relevance of learning chemistry & .072 & .268 & .263 & 1 & & \\
5. Self-efficacy for cognitive skills & .178 & .483 & .261 & .176 & 1 & \\
6. Self-efficacy for chemistry laboratory & -.030 & .159 & .240 & .290 & .364 & 1 \\
\hline
\end{tabular}

Finally, the assumption of the homogeneity of variance-covariance matrices was tested via Box's test. As seen in Table 15, the Box's M test indicated a non-significant result $(F=.835, p>.001)$, supporting the conclusion of homogeneity of variance-covariance matrices. Therefore, this assumption was met, too. 
Table 15 Box's M Test of Equality of Covariance Matrices

\begin{tabular}{lr}
\hline Box's M & 18.610 \\
F & .835 \\
df1 & 21 \\
df2 & 44558.890 \\
Sig. & .678 \\
\hline
\end{tabular}

\subsubsection{Results of MANOVA for the Post-tests Scores}

After satisfying all the assumptions for performing the MANOVA, oneway MANOVA was run for the post-test scores to examine the effect of casebased instruction on students' understanding of electrochemistry, attitude, intrinsic motivation, perceptions regarding relevance of learning chemistry to personal goals, self-efficacy for cognitive skills and chemistry laboratory when compared to traditional instruction. Table 16 depicts MANOVA results:

Table 16 The results of one-way MANOVA for the post-test scores

\begin{tabular}{llccccccc}
\hline & & & \multicolumn{4}{c}{ Partial } \\
Effect & & \multicolumn{3}{c}{$\begin{array}{c}\text { Error } \\
\text { df }\end{array}$} & $\begin{array}{c}\text { Eta } \\
\text { Sig. Squared }\end{array}$ & $\begin{array}{c}\text { Observed } \\
\text { Power }\end{array}$ \\
\hline Intercept & & Pillai's Trace & 859.744 & 6 & 106 & .000 & .980 & 1.000 \\
& Wilks' Lambda & 859.744 & 6 & 106 & .000 & .980 & 1.000 \\
& Hotelling's Trace & 859.744 & 6 & 106 & .000 & .980 & 1.000 \\
& Roy's Largest Root & 859.744 & 6 & 106 & .000 & .980 & 1.000 \\
\hline Treatment & Pillai's Trace & 3.678 & 6 & 106 & .002 & .172 & .949 \\
& Wilks' Lambda & 3.678 & 6 & 106 & .002 & .172 & .949 \\
& Hotelling's Trace & 3.678 & 6 & 106 & .002 & .172 & .949 \\
& Roy's Largest Root & 3.678 & 6 & 106 & .002 & .172 & .949 \\
\hline
\end{tabular}

Results revealed that there was a statistically significant mean difference between experimental and the control groups with respect to combined dependent variables of understanding of electrochemistry, attitude, intrinsic motivation, perceptions regarding relevance of learning chemistry to 
personal goals, self-efficacy for cognitive skills and chemistry laboratory after the treatment: $F(6,106)=3.678, p<0.05$; Wilks' Lambda $=0.828$. The value of Partial-Eta Squared based on Wilk's Lambda, 0.172, indicated that the magnitude of the difference between experimental and control groups was not small. In other words, it means that $17.2 \%$ of multivariate variance of the dependent variables could be explained by the treatment. The value of power, another important statistics, was found to be .949 . These findings implied that the difference between the experimental and control groups arouse from the treatment effect and this difference had practical value.

Given the significance of the overall test, the univariate main effects (tests of between subjects' effects) were examined by follow-up ANOVA. Before interpreting the result of ANOVA, the assumption of equality of variances was checked. Result of Levene's test is displayed in Table 17.

Table 17 Levene's Test of Equality of Error Variances

\begin{tabular}{lcccc}
\hline & F & df1 & df2 & Sig. \\
\hline Understanding of electrochemistry & 10.354 & 1 & 111 & .002 \\
Attitude toward chemistry & .405 & 1 & 111 & .526 \\
Intrinsic motivation & .018 & 1 & 111 & .894 \\
Relevance of learning chemistry & .128 & 1 & 111 & .721 \\
Self-efficacy for cognitive skills & .490 & 1 & 111 & .485 \\
Self-efficacy for chemistry laboratory & .195 & 1 & 111 & .660 \\
\hline
\end{tabular}

Result of Levene's test showed that each dependent variable had the same variance across groups as the significance value less than .005, except for understanding of electrochemistry. Since this assumption was not met for one of the dependent variable, a higher alpha level, .04, was selected to interpret the results of follow-up ANOVA. In addition, Bonferroni adjusted alpha level was used in order to reduce the change of Type 1 error because a number of separate analyses would be considered. For this purpose, the original alpha level of .04 was divided by the number of dependent variables, which were six, 
and the new alpha level was set as .0067 . When the results for the dependent variables were considered separately, three statistically significant differences were detected by using Bonferroni adjusted alpha level of.0067 (see Table 18). 
Table 18 Result of univarite tests for the between-subject effects of one-way MANOVA for the post-tests scores

\begin{tabular}{|c|c|c|c|c|c|c|c|c|c|}
\hline Source & Dependent Variable & $\begin{array}{l}\text { Type III } \\
\text { Sum of } \\
\text { Squares }\end{array}$ & $\mathrm{df}$ & & $\begin{array}{l}\text { Mean } \\
\text { Square }\end{array}$ & $\mathrm{F}$ & Sig. & $\begin{array}{c}\text { Partial } \\
\text { Eta } \\
\text { Squared }\end{array}$ & $\begin{array}{l}\text { Observed } \\
\text { Power }\end{array}$ \\
\hline \multirow[t]{6}{*}{$\begin{array}{l}\text { Corrected } \\
\text { Model }\end{array}$} & $\begin{array}{l}\text { Understanding of } \\
\text { electrochemistry }\end{array}$ & 150.218 & & 1 & 150.218 & 8.026 & .005 & .067 & .802 \\
\hline & Attitude toward chemistry & 2.967 & & 1 & 2.967 & 7.849 & .006 & .066 & .793 \\
\hline & Intrinsic motivation & 3.313 & & 1 & 3.313 & 8.443 & .004 & .071 & 821 \\
\hline & Relevance of learning chemistry & .952 & & 1 & .952 & 1.468 & .228 & .013 & .225 \\
\hline & Self-efficacy for cognitive skills & 7.737 & & 1 & 7.737 & 7.035 & .009 & .060 & .748 \\
\hline & $\begin{array}{l}\text { Self-efficacy for chemistry } \\
\text { laboratory }\end{array}$ & 24.232 & & 1 & 24.232 & 7.455 & .007 & .063 & .772 \\
\hline \multirow[t]{6}{*}{ Intercept } & $\begin{array}{l}\text { Understanding of } \\
\text { electrochemistry }\end{array}$ & 22475.882 & & 1 & 22475.882 & 1200.827 & .000 & .915 & 1.000 \\
\hline & Attitude toward chemistry & 1018.726 & & 1 & 1018.726 & 2694.901 & .000 & .960 & 1.000 \\
\hline & Intrinsic motivation & 875.104 & & 1 & 875.104 & 2230.297 & .000 & .953 & 1.000 \\
\hline & Relevance of learning chemistry & 962.590 & & 1 & 962.590 & 1484.126 & .000 & .930 & 1.000 \\
\hline & Self-efficacy for cognitive skills & 2960.800 & & 1 & 2960.800 & 2692.198 & .000 & .960 & 1.000 \\
\hline & $\begin{array}{l}\text { Self-efficacy for chemistry } \\
\text { laboratory }\end{array}$ & 2369.730 & & 1 & 2369.730 & 729.049 & .000 & .868 & 1.000 \\
\hline
\end{tabular}


Table 18 Result of univarite tests for the between-subject effects of one-way MANOVA for the post-tests scores (continued)

\begin{tabular}{|c|c|c|c|c|c|c|c|c|}
\hline Source & Dependent Variable & $\begin{array}{l}\text { Type III } \\
\text { Sum of } \\
\text { Squares }\end{array}$ & $\mathrm{df}$ & $\begin{array}{l}\text { Mean } \\
\text { Square }\end{array}$ & $\mathrm{F}$ & Sig. & $\begin{array}{c}\text { Partial } \\
\text { Eta } \\
\text { Squared }\end{array}$ & $\begin{array}{l}\text { Observed } \\
\text { Power }\end{array}$ \\
\hline \multirow[t]{6}{*}{ Treatment } & $\begin{array}{l}\text { Understanding of } \\
\text { electrochemistry }\end{array}$ & 150.218 & 1 & 150.218 & 8.026 & .005 & .067 & .802 \\
\hline & Attitude toward chemistry & 2.967 & 1 & 2.967 & 7.849 & .006 & .066 & .793 \\
\hline & Intrinsic motivation & 3.313 & 1 & 3.313 & 8.443 & .004 & .071 & .821 \\
\hline & Relevance of learning chemistry & .952 & 1 & .952 & 1.468 & .228 & .013 & .225 \\
\hline & Self-efficacy for cognitive skills & 7.737 & 1 & 7.737 & 7.035 & .009 & .060 & .748 \\
\hline & $\begin{array}{l}\text { Self-efficacy for chemistry } \\
\text { laboratory }\end{array}$ & 24.232 & 1 & 24.232 & 7.455 & .007 & .063 & .772 \\
\hline \multirow[t]{6}{*}{ Error } & $\begin{array}{l}\text { Understanding of } \\
\text { electrochemistry }\end{array}$ & 2077.587 & 111 & 18.717 & & & & \\
\hline & Attitude toward chemistry & 41.960 & 111 & .378 & & & & \\
\hline & Intrinsic motivation & 43.553 & 111 & .392 & & & & \\
\hline & Relevance of learning chemistry & 71.994 & 111 & .649 & & & & \\
\hline & Self-efficacy for cognitive skills & 122.075 & 111 & 1.100 & & & & \\
\hline & Laboratory efficacy & 360.799 & 111 & 3.250 & & & & \\
\hline
\end{tabular}


Table 18 Result of univarite tests for the between-subject effects of one-way MANOVA for the post-tests scores (continued)

\begin{tabular}{|c|c|c|c|c|c|c|c|c|}
\hline Source & Dependent Variable & $\begin{array}{l}\text { Type III } \\
\text { Sum of } \\
\text { Squares }\end{array}$ & df & $\begin{array}{l}\text { Mean } \\
\text { Square }\end{array}$ & $\mathrm{F}$ & Sig. & $\begin{array}{c}\text { Partial } \\
\text { Eta } \\
\text { Squared }\end{array}$ & $\begin{array}{l}\text { Observed } \\
\text { Power }\end{array}$ \\
\hline \multirow[t]{6}{*}{ Total } & $\begin{array}{l}\text { Understanding of } \\
\text { electrochemistry }\end{array}$ & 24911.000 & 113 & & & & & \\
\hline & Attitude toward chemistry & 1070.532 & 113 & & & & & \\
\hline & Intrinsic motivation & 928.467 & 113 & & & & & \\
\hline & Relevance of learning chemistry & 1040.110 & 113 & & & & & \\
\hline & Self-efficacy for cognitive skills & 3109.855 & 113 & & & & & \\
\hline & $\begin{array}{l}\text { Self-efficacy for chemistry } \\
\text { laboratory }\end{array}$ & 2780.706 & 113 & & & & & \\
\hline \multirow[t]{6}{*}{$\begin{array}{l}\text { Corrected } \\
\text { Total }\end{array}$} & $\begin{array}{l}\text { Understanding of } \\
\text { electrochemistry }\end{array}$ & 2227.805 & 112 & & & & & \\
\hline & Attitude toward chemistry & 44.927 & 112 & & & & & \\
\hline & Intrinsic motivation & 46.866 & 112 & & & & & \\
\hline & Relevance of learning chemistry & 72.946 & 112 & & & & & \\
\hline & Self-efficacy for cognitive skills & 129.811 & 112 & & & & & \\
\hline & $\begin{array}{l}\text { Self-efficacy for chemistry } \\
\text { laboratory }\end{array}$ & 385.031 & 112 & & & & & \\
\hline
\end{tabular}


One of significant mean differences was observed in the students' understanding of electrochemistry: $F(1,111)=8.026, p<.0067$. The mean scores on the electrochemistry concept test indicated that students in the experimental group had significantly higher mean score $(\mathrm{M}=15.271, \mathrm{SD}=$ 4.961) than those in the control group $(\mathrm{M}=12.963, \mathrm{SD}=3.502)$ (Hypothesis 1). Another significant mean differences was found between experimental and the control groups with respect to students' attitudes towards chemistry: $F(1$, 111) $=7.849, p<.0067$. The mean scores on the attitude toward chemistry scale indicated that students in the experimental group had significantly higher score $(M=3.168, S D=0.616)$ than those in the control group $(M=2.843, S D$ $=0.614)$ (Hypothesis 2). Finally, the results of follow-up ANOVA indicated that there was a statistically significant mean difference between experimental and the control groups in terms of students' intrinsic motivation in chemistry: $F$ $(1,111)=8.443, p<.0067$. Students in the experimental group had significantly higher mean score of intrinsic motivation $(\mathrm{M}=2.957, \mathrm{SD}=$ $0.621)$ than those in the control group $(\mathrm{M}=2.614, \mathrm{SD}=0.633)$ (Hypothesis 3$)$. The values of Partial-Eta Squared were found as .067, .066, and .071 for understanding of electrochemistry, attitude toward chemistry, and intrinsic motivation, respectively. These values indicated that approximately $7 \%$ of multivariate variance of the dependent variables (understanding of electrochemistry, attitude toward chemistry, and intrinsic motivation) was associated with the treatment. The values of power were found as .802, .793, and .821 for understanding of electrochemistry, attitude toward chemistry, and intrinsic motivation, respectively. These findings implied that the difference between the experimental and control groups arouse from the treatment effect and had practical value.

On the other hand, although students in the experimental group had higher mean score of relevance of learning chemistry to personal goals $(\mathrm{M}=3.013$, $\mathrm{SD}=0.769)$ than those in the control group $(\mathrm{M}=2.830, \mathrm{SD}=0.844)$, the mean difference between the groups was not significant: $F(1,111)=1.468, p>$ 
.0067 (Hypothesis 4). In addition, there was no statistically significant mean difference between experimental and the control groups in terms of students' chemistry self-efficacy for cognitive skills $(F(1,111)=7.035, p>.0067)$ and self-efficacy for chemistry laboratory $(F(1,111)=7.455, p>.0067)$ (Hypothesis 5 and 6). However, the mean score of the experimental group on these dependent variables was higher than the control group.

Briefly, as can be examined from Table 13, the mean score of the experimental group on each dependent variable was higher than the control group; but only the scores on electrochemistry concept test, attitude toward chemistry, and intrinsic motivation were significant.

\subsection{Results of Student Interviews}

In this study, semi-structured interviews were conducted with a total of twelve students from both experimental and control group. Six students from experimental group (Giray, Burcu, Ceren, Gizem, Buket, Yaren) and six students from control group (Aykut, Elif, Kezban, Damla, Halide, Pelin) were selected by considering the representation of each high school for the sample of interviewees. In each group of students, three high scoring students and three low scoring students in the post ECT formed the sample of interviewees for present study. The purpose of conducting interviews was to obtain deeper information about students understanding and reasoning of electrochemistry concepts and to compare them according to the experimental and control group. To achieve this purpose, it was benefited from the items of ECT which were answered incorrectly by more than half of the sample. Figure 5 presents percentages of all students' correct and wrong responses to the post-ECT. During the interviews, students were asked questions about which they mostly gave incorrect answers in this test. When the percentage of answers to those questions was examined, it has been noticed that control group students had more incorrect answers than experimental group students. Results will be presented with respect to electrochemistry concepts covered in the test. 


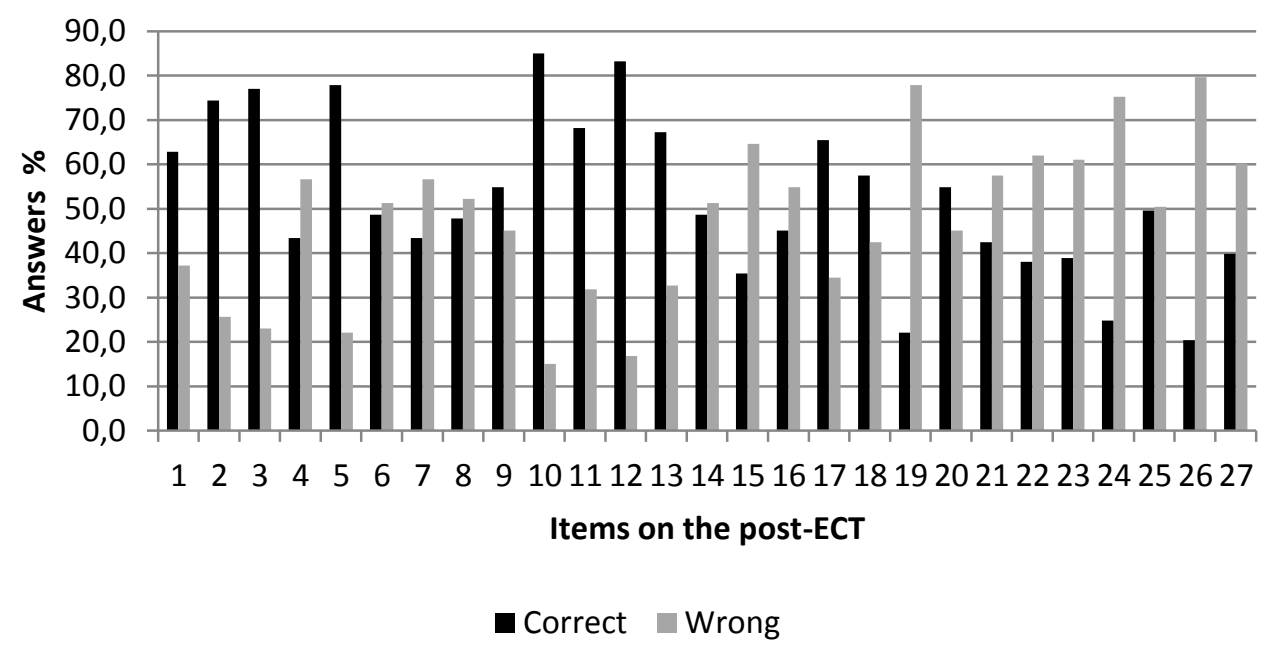

Figure 5 The bar chart of the percentages of students' correct and wrong answers on the post-ECT

a) Understandings of the Concepts of Oxidation, Reduction, Oxidizing Agent, and Reducing Agent, and identification of chemicals oxidized and reduced in a redox

Students' understandings of oxidation, reduction, oxidizing agent, and reducing agent concepts and their identification of chemicals oxidized and reduced in a redox reaction were investigated through asking them question 4 during the interview. The responses showed that all interviewees from the experimental group had correct understandings of these concepts. Regarding the identifcation of the chemicals oxidized and reduced in the redox reaction given in the question, almost all of them answered the question correctly. Only one of them, Giray, gave incorrect answers although he had correct understandings of the related concepts. His descriptions about the concepts as follows:

Researcher (R): What we call as reducing agent?

Giray $(\mathrm{G})$ : The subject losing an electron is called reducing agent.

$\mathrm{R}$ : Before this, tell me what reduction is.

$\mathrm{G}$ : Reduction is gaining electron, oxidation is losing electron.

$\mathrm{R}$ : OK. As a result, what are the reducing and oxidizing agents terms? 
G: Reducing agents is the subject oxidized, oxidizing agent is the subject reduced.

$\mathrm{R}: \mathrm{OK}$.

However, he identified the chemicals oxidized and reduced in the redox reaction given in the question incorrectly. He thought that oxidation state of the Chlorine was always -1 since it was the element of 7A group in the periodic system. In addition, he did not know the oxidation state of the Potassium although he knew it was a metal. Therefore, he stated that while $\mathrm{S}$ was oxidizing, $\mathrm{K}$ was reducing. He identified $\mathrm{K}$ and $\mathrm{S}$ as oxidizing and reducing agent, respectively, which was incorrect.

On the other hand, all interviewees in control groups, except Aykut, also explained the oxidation, reduction, oxidizing agent, and reducing agent concepts correctly. Aykut had difficulty in explaining the concepts and confused the meaning of them. Regarding the identification of the chemicals oxidized and reduced in the redox reaction, only one of the students having correct understandings about concepts in the control group (Elif) gave correct answers. Other students in the control group identified the chemicals oxidized and reduced in the redox reaction incorrectly due to their insufficient knowledge of periodic system. These students (Kezban and Damla, Halide, Pelin) did not know the element of $\mathrm{K}$ or the oxidation state of it or thought that oxidation state of the Chlorine was always -1. For example, Damla's reasoning for the identification of chemicals oxidized and reduced in the redox reaction given in the question 4 was as follows:

Researcher (R): Here [in her paper], you got oxygen as -2 , chlorine as 1 .

Damla (D): Yes.

$\mathrm{R}: \mathrm{K}$ is +7

$\mathrm{D}$ : We had already know that Oxygen is -2 .

R: hi1mm

$\mathrm{D}$ : Chlorine is $-1 . \mathrm{K}$ had to be 7 to equal to total as zero.

$\mathrm{R}$ : Do you know the name of the element $\mathrm{K}$ ?

D: umm I don't know.

R: You don't know. If I said that it was Potassium, could you say the group of it in the preiodic system? 
D: In which group Potassium i... not $7 \mathrm{~A}$, not $1 \mathrm{~A}$, not $2 \mathrm{~A} . .$. no it is probably in 7A... I don't know.

R: OK. It is not important. You got Chlorine as -1 .

D: Yes.

$\mathrm{R}$ : Is chlorine always -1 ?

D: I remember that it always get -1 .

$\mathrm{R}$ : H11mm as a result, you got $\mathrm{K}$ as 7 .

D: Yes.

$\mathrm{R}$ : What is the oxidation state of $\mathrm{K}$ in $\mathrm{KCI}$ ?

$\mathrm{D}$ : Since Chlorine is -1 here $\mathrm{K}$ is +1 .

R: H11mm

$\mathrm{D}$ : Therefore, I thought that $\mathrm{K}$ was the oxidizing agent.

R: Why?

D: Because it was reduced. As a result, I said it was the oxidizing agent.

To sum up, except one students from the control group, all interviewees explained the oxidation, reduction, oxidizing agent, and reducing agent concepts correctly. However, most of the interviewees from the control group identified the chemicals oxidized and reduced in the redox reaction given in the question incorrectly due to their insufficent knowledge about the periodic system.

\section{b) Understandings of Electrolysis}

Students were asked how they decide product that is formed at anode and cathode during the electrolysis by the help of question 14 and 15 . The answers showed that half of experimental and some of control group students answered correctly by using the values of reduction potentials given in the questions or their knowledge about reactivity of elements to decide the products of anode and cathode. For products of cathode they compared the cations' reduction potentials or reactivity. They thought that the cation which has higher reduction potential value is reduced at the cathode. On the other hand, for products of anode they compared the anions' reduction values and claimed that the anion which has lower reduction potential value is oxidized at the anode or they changed the reduction potential values to the oxidation potentials values and then selected the anion which has high oxidation potential 
value for oxidized subject at the anode. For example, an experimental group student, Burcu, explained her reasoning for question 14 as following.

Firstly, I grouped $\mathrm{H}^{+} \mathrm{OH}^{-} \mathrm{K}^{+} \mathrm{CI}^{-} \mathrm{Na}^{+}$according to their charge as negative and positive. Positively charged ions go to cathode; negatively charged ions go to anode. It was asked to me which subject would be formed at the cathode firstly. At cathode, there is a reduction and I thought that the subject which had higher features in terms of reduction is the first subject formed at the cathode. By looking at their reduction potential given in the question I decided that Hydrogen would be formed firstly.

As an example from control group, Damla told that

Firstly, we separated these matters into their ions. For example, we separated $\mathrm{H}_{2} \mathrm{O}$ as $\mathrm{H}^{+}$and $\mathrm{OH}^{-}$. We separated as $\mathrm{K}^{+}$and $\mathrm{CI}^{-}$and then $\mathrm{Na}^{+}$ and $\mathrm{Cl}^{-}$. At cathode, positive ions, positively charged ions are gathered. Their oxidation potentials were given...no...their reduction potentials were given. The matter had lower reduction potentials....no...higher reduction potential goes to cathode and that had lower goes to anode. We also learned the sequence of these matters. How was it?.. It was as $\mathrm{K}^{+}<\mathrm{Na}^{+}<\mathrm{H}^{+}$. Therefore, the gas of Hydrogen is formed firstly.

Regarding question 15, Ceren, an experimental group student, explained as

Here, the relationship among their standard reduction potential was given. That means, the oxidation potential of Aluminum is highest among them. I thought that there is Hydrogen into the solution. Since the oxidation potential of Aluminum is higher than Hydrogen Aluminum do not want to go to cathode in order to be reduced. Therefore, Hydrogen comes into play. Instead of Aluminum, Hydrogen gains electrons and Hydrogen gas will be formed. I applied opposite reasoning for others. In other words, negatively charged ions should be had less reduction potentials in order to go to the anode to be oxidized. They should have tendency to be oxidized. Here, Brome has more tendency to be oxidized since its reduction potential is less.

However, one experimental group student (Giray) and more than half of the control group students answered incorrectly although they know how they use reduction potentials given in the questions. They thought that the subject which has the highest value of reduction potentials was reduced at the cathode. Although their thoughts are right, they could not think whether that subject could be reduced or not in that system given in the questions. In other words, they did not consider whether anion form of that element was in the solution or 
not in order to be reduced to its elemental form. For example, Halide, a control group student, expressed her ideas as follow.

Halide $(\mathrm{H})$ : I think it is related to higher reactivity

Researcher (R): how do you decide reactivity? What do these E values indicate?

$\mathrm{H}$ : Their reactivity

$\mathrm{R}$ : in which direction?

$\mathrm{H}$ : for example, here they all gain electrons. The highest value is belonging to Chlorine.

R: hımm

$\mathrm{H}$ : I think it is more reactive.

$\mathrm{R}$ : at cathode, what happens?

$\mathrm{H}$ : at cathode, reduction occurs

$\mathrm{R}$ : during reduction, does the subject gain or loss electron?

$\mathrm{H}$ : during reduction. One minute. I am thinking the seesaw. It gains electron.

R: It gains electron. OK. When we look at the E values, they all gain electrons. And it is asked that which subject would be formed at cathode.

$\mathrm{H}$ : yes.

R: what can you say? Which one would be reduced?

$\mathrm{H}$ : the one having highest reduction potential. It is Chlorine.

$\mathrm{R}$ : what is the product of cathode?

$\mathrm{H}$ : Chlorine gas.

Moreover, an experimental group student (Gizem) compared only reactivity of metals given in the question to decide the product of cathode since they thought the working principle of electrolysis is the opposite of the electrochemical cells.

Gizem (G): Since reduction occurs ay cathode I tried to select metal.[she was reading the question 14]. I focused on Potassium and Sodium.

Researcher (R): Why did you consider only them?

$\mathrm{G}$ : they are metals and reduction occurs at cathode. Electrolysis is opposite of electrochemical cells. Therefore, metals are reduced, nonmetals are oxidized during electrolysis.

R: When you say metal, do you mean ion of metal?

G: Yes.

$\mathrm{R}$ : like cation. Are they metal here?

$\mathrm{G}$ : in ion form

$\mathrm{R}:$ himm... but sodium and potassium are metal?

G: Yes.

$\mathrm{R}$ : now, they are in ion form. 
G: yes

R: you considered these elements for reduction, didn't you?

G: yes.

R: you didn't consider other subjects.

G: yes. I didn't consider them. After that, I thought that it was difficult to separate potassium from the solution since it was more strong than Sodium. When we compared them, sodium occurs at cathode easily since it was weaker than Potassium.

R: Why do you think that Potassium is stronger than Sodium?

G: Metallic properties increase when we go down in a group in periodic system.

R: h11m

G: therefore, I thought that Potassium has more metallic properties than sodium and it is difficult to separate it.

$\mathrm{R}$ : what do separating mean? Where do we separate it from?

G: it gives electron in normal conditions [in electrochemical cell] and it is oxidized. However, we will do the exact opposite. That is, it will be reduced. Therefore, I thought that the one which has less metallic properties will be reduced easily.

Furthermore, one of the experimental group students (Buket)

interpreted the reduction potentials of subject given in the questions incorrectly. She thought that the subject having smallest value of reduction potential would be formed firstly at the cathode. Therefore, she gave Potassium as an answer of the question 14.

During the interviews, it was seen that students had also insufficient knowledge about electrolysis of water (question 16). Most of the experimental group students (Yaren, Burcu, Ceren, Giray) and half of the control group students (Pelin, Kezban, Aykut) knew that during the electrolysis water compound separated into its elements, two Hydrogen atoms and one Oxygen atom. However, one of them from each group (Giray, Aykut) could not decide the anode and cathode correctly. On the other hand, two experimental students (Gizem, Buket) and half of the control group students (Damla, Halide, Elif) knew the electrolysis of water as separating into ions. Therefore, they thought water was separated into its ions such as $\mathrm{H}^{+}$and $\mathrm{OH}^{-}$during the electrolysis.

To summarize, although most of the interviewees from the both experimental and control group had knowledge about interpretation of the 
values of reduction potentials given in the questions or reactivity of elements, some interviewees from the both group had insufficent knowledge about electrolysis, especially electrolysis of water. However, more interviewees from the experiemantal group decided the products of anode and cathode correctly than those from the control group.

\section{c) Understandings of Electroplating}

Students' understating about the process of electroplating was evaluated through asking the question 21 and 27. Their responses indicated that four experimental and two control group students answered correctly by using the terms anode, cathode, electrolyte and the electron flow. For example, Yaren, an experimental group student, told as following.

Yaren (Y): here, firstly, I thought that since it was plated by Silver, there should be a solution including component of Silver. Then, I thought that silver should be at anode since oxidation occurs at anode. The concentration of Silver ions in the solution will increases since silver is oxidized at anode.

Researcher (R): ho w did you decide pole of the battery?

Y: We did an experiment. In that experiment, we made connection between the + with + , and between - and-. I remembered it.

$\mathrm{R}$ : you thought that anode was + .

G: I thought like that because we connected the anode with + , the cathode with - in that experiment.

R: OK. How does this system work? How is the copper material plated by silver?

Y: Now, since copper is cathode reduction reaction occurs there and silver ions in the solution turn into solid silver. Hence, copper is plated by silver.

$\mathrm{R}$ : what is reduced?

$\mathrm{Y}$ : are you asking for the subject reducing in this system?

$\mathrm{R}$ : at cathode

Y: silver ions inside in the solution are reduced.

R: OK. Does the copper have any function in this system?

Y: Cooper only serves as cathode. That is, it provides electron transfer.

$\mathrm{R}$ : OK. Yu said that silver ions are reduced and cover the copper. What happens on the other side [anode]?

$\mathrm{Y}$ : at this side, silver turns into silver ions in order to prevent running out Ag+.

$\mathrm{R}$ : OK. What is the function of + and - pole of the battery? What does battery serve for?

Y: battery helps us to decide anode and cathode side. 
$\mathrm{R}$ : what is the function of the battery in this system?

$\mathrm{Y}$ : by providing electrical energy, it provides electrons.

$\mathrm{R}$ : to where?

Y: solution

$\mathrm{R}$ : from which side?

Y: electron flow occurs from negative side.

$\mathrm{R}$ : Do electrons come to the copper?

Y: yes, they come to the copper. Then silver ions gain these electrons and they are reduced.

Aykut, a control group student, also explained his reasoning as follow:

Researcher (R): There is question about electroplating. To plate a cooper material by silver, this system was designed.

Aykut (A): Yes

$\mathrm{R}$ : Which materials should be used in the places numbered in the picture? In electroplating, which materials are needed? What kind of mechanism should we establish?

A: We need to establish a mechanism like this. Firstly, in the placenumbered as 3 , there should be silver because it plates the material. In the place numbered as 2 , toy or something.... what we plate... copper will be plated by silver. Therefore, in the place numbered as 2, there should be copper. After that, the solution has to include silver in order to cover the copper. Then, ... we wrote $\mathrm{Cu}$ in the place numbered as 2 .

R: number 1

A: Ag. Here, I thought a portion of it should be eroded away.

R: OK. Let's talk about your drawing. We put silver here [in the place numbered as 1]. You draw such an arrangement. How does it work?

A: um.. I think it now.

$\mathrm{R}: \mathrm{OK}$ :

A: Electrons come to AgNO3, Ag+ takes one electron and than cover the copper.

R: h11mm

A: Electrons from here...the place numbered as 5 is negative.

R: Yes

A: electrons goes to the AgNO3 solution passing through copper wire. $\mathrm{Ag}+$ ions in the solution become Ag, elemental state. Then, it covers the copper.

$\mathrm{R}$ : after that?

A: here [in the place numbered as 1], I think some amounts of Ag are eroded away.

R: Why?

A: It is required.

R: Why?

A: I have never used it until now 
$\mathrm{R}$ : OK. Where is anode and cathode?

A: We said that cathode is the place where reduction cocurs. What is reduction..reduction is to gain electron. Which takes the electron here? Ag. Since Ag receives the electron it should accumulate here..on the copper. We said it gains the electrons.

R: H111mm

A: Therefore, here is the cathode [number 2] and here is the anode [number 1]

$\mathrm{R}$ : What happens at the anode?

A: We said reduction occurs...sorry oxidation occurs at the anode.

What happen..we gives electron from here. Ag is zero.

R: H11mm

A: it gives an electron and becomes $\mathrm{Ag}+$.

R: H11mm

A: It becomes Ag+.

$\mathrm{R}$ : Where does the electron given by the Ag? Where it go to?

A: the electron goes the place numbered as 4 , from here to the place numbered as 5 and then again go to the down [solution]. This [Ag] is eroded away.

$\mathrm{R}$ : why the electron is not received by thecopper and it goes to the solution?

A: because copper is already in elemental state here.

R: h11mm

A: Copper is zero.

However, two experimental and four control group students answered the questions incorrectly. Experimental group students had some knowledge about electroplating such as Ag+ was reduced and cover on the copper electrode. In addition, they knew that the figure in the question 27 is related to electroplating and iron key was electroplated by copper in that process. However, they could not explain their claim by using the term of electron flow or microscopic level. On the other hand, some control group students had insufficient knowledge than experimental group students. Control group students could not relate the same figure with electroplating or electrolysis and make interpretation about electroplating. For example, Damla could not explain the process of electroplating.

Researcher (R): In the question 21, there is a system to electroplate a copper material by silver. Which materials should be placed on places indicated with numbers from 1 to 5 in order to plate copper by silver? 
Damla (D): we should use copper and silver. I don't know how copper plating occurs. I suppose that we use copper.

$\mathrm{R}$ : we had a copper material and we want to cover it with silver.

D: with silver

$\mathrm{R}$ : yes, do you know how plating is done?

D: No. I think it is immersed into a solution.

R:hı1m...For example, if we immerse cooper into silver solution...

D: No, it doesn't like that. As I remember, we use materials containing copper. Then, they are joined each other [silver and copper] in order to react each other and be plated by silver.

$\mathrm{R}$ : Does it occur spontaneously? In other words, is it enough to put together silver and copper for plating?

D: I think not.

In addition, one of the control group students (Halide) thought that

electrolysis was separating the matter into its ions such as electrolysis of water.

Halide knows only the electrolysis of water related to the concept of

electrolysis. She explained her ideas as following.

Researcher (R): In the question 27, there are a power source, copper rod, iron key and copper sulphate solution. What do you say about working of this system? What happens in this system?

Halide $(\mathrm{H})$ : in this system?

$\mathrm{R}$ : don't think about the alternatives given in the question. What do you know about this system? Is a electrochemical cell or anything else?

H: I think it isn't a cell. There is a power source. What does it serve for?

R: Power source.. Is it a electrochemical cell or a different circuit?

What do you think?

$\mathrm{H}$ : I think it is different from a cell.

R: What can it be? What do you know except electrochemical cell?

$\mathrm{H}$ : electrolysis

R: him. Can it be electrolysis?

H: No, it can't.

$\mathrm{R}$ : Why? What is electrolysis?

$\mathrm{H}$ : For example, electrolysis of water. However, there is an iron and copper. It is irrelevant.

R: Can you draw an electrolytic cell? How can you image it?

$\mathrm{H}$ : when electrolysis is said, I only remember $\mathrm{H}+$ and $\mathrm{OH}-$.

$\mathrm{R}$ : Should there a one substance? Is there any electrode?

$\mathrm{H}$ : yes, there is. They are in the same container [cell] unlike the electrochemical cell.

$\mathrm{R}$ : What is the function of the battery in this system? What do iron, copper and solution serve for?

H: Now, I don't have any idea. 
R: OK.

Moreover, all of the control group students could not interpret the serve of the battery in the electroplating process. For example, Elif said that "when we use a power source, I think it can reduce the time for the process. It enables electrons to be separated more quickly.".

Briefly, interviewees from the experimental group had a greater understanding about the electroplating concept than those from the control group. They were more knowledge about the electroplating process regarding identification of anode, cathode, and electron flow. While four interviewees from the experimental group answered the questions 21 and 27 correctly with sufficient explanation during the interview, only two interviewees from the control group answered correctly.

\section{d) Understandings of Corrosion}

Students' understating about corrosion and protection of matter from it was evaluated through asking the question 22, 23, 24 and 25. Their responses indicated that all of the experimental group students could explain the term of corrosion or rusting whereas half of the control group students could explain it. For example, an experimental group student (Giray) described as follow:

Researcher $(\mathrm{R})$ : Do you know what corrosion is?

Giray $(\mathrm{G})$ : Corrosion is abrasion [damage of a metal]

R: OK. What happens during abrasion? What does abrade? What kinds of abrasion are called as corrosion?

G: For example corrosion of an iron

$\mathrm{R}$ : Corrosion of an iron. How does an iron corrode?

$\mathrm{G}$ : It is rusted.

R: Rusting OK. What happens during rusting of an iron?

G: Oxidation-reduction reaction, redox, occurs.

$\mathrm{R}: \mathrm{OK}$. Which is oxidized and reduced?

$\mathrm{G}$ : Iron is oxidized, oxygen is reduced.

A control group student (Halide) explained as following.

Researcher ( $\mathrm{R})$ : What is rusting?

Halide $(\mathrm{H})$ : I know it as oxidation.

$\mathrm{R}$ : What happens during oxidation? 
H: A metal which shouldn't be unreactive combine with oxygen and it is rusted.

R: During rusting, i.e., forming a compound, what happens to the metal? Is there any chemical reaction?

$\mathrm{H}$ :There should be an oxidation-reduction reaction. Can I write the reaction?

R: Of course.

$\mathrm{H}$ : For example, we think that the metal is iron.

$\mathrm{R}$ : OK. It is iron.

$\mathrm{H}$ : [Writing the reaction ] $\mathrm{Fe}+\mathrm{O}_{2} \longrightarrow \mathrm{FeO}$

R: H11m

$\mathrm{H}$ : These [charges of $\mathrm{Fe}$ and $\mathrm{O}_{2}$ ] are zero. When they are formed the compound, the charge of the Oxygen is -2 .

R: H11m

$\mathrm{H}$ : When it is -2 , the charge of the iron is +2 . Therefore, iron lost its electrons and it was oxidized.

Although other two control group students know that corrosion or rusting is a redox reaction or a reaction between metal and oxygen, they did not explain which subject was oxidized or reduced during the corrosion or rusting correctly. For example, Kezban's expression is below.

Researcher (R): Do you know what rusting is?

Kezban $(\mathrm{K})$ : I think it is an oxidation-reduction reaction.

$\mathrm{R}$ : Rusting involves oxidation-reduction reaction, doesn' $t$ ' it?

$\mathrm{K}$ : I think it does.

$\mathrm{R}$ : between which? Which is oxidized and reduced if you think that rusting of iron?

$\mathrm{K}$ : The charge of iron is +3 or it can be +2 .

$\mathrm{R}$ : For iron?

$\mathrm{K}$ : It should be reduced.

$\mathrm{R}$ : Think an iron pipe. What is the charge of the iron?

$\mathrm{K}$ : It is zero, isn't it?

$\mathrm{R}$ : OK. It is zero. What happens when it is rusted?

$\mathrm{K}$ : It takes Oxygen. Therefore, I think it is reduced.

$\mathrm{R}$ : To which charge is the iron reduced?

$\mathrm{K}$ : It can't be reduced from zero. It should gain electrons. Its charge should be +3 and lose its electrons. I don't know.

Similarly, Damla thought that metal is reduced during the rusting. Her response is below.

Researcher (R): Do you know what corrosion is?

Damla (D): I don't know.

$\mathrm{R}$ : what about rusting? 




Except one of them, experimental group students thought that oxygen and water are needed for rusting of iron while only one student (Elif) in control group consider the effect of water during rusting process. Three control group students thought that only oxygen is needed for rusting of the nail. For example, the explanation of a control group student (Damla) is given below.

Researcher $(\mathrm{R})$ : Does rusting occur in both moist and dry air?

Damla (D): Yes, it does.

R: Why?

D: because it reacts with Oxygen.

R: Hi1m. Is there any oxygen in dry air?

D: Yes, there is air in dry air.

$\mathrm{R}$ : what about in moist air?

D: In moist air, there is already Oxygen due to moist.

Similarly, Aykut and Pelin thought that corrosion occurs everywhere if there is oxygen. The response of Pelin for the question 23 is presented below.

Researcher (R): In the question 23, there is nail in the water.

Pelin $(\mathrm{P})$ : Yes

$\mathrm{R}$ : Does rusting occur here?

P: It occurs.

R: Why?

P: I could not explain scientifically, I just know it occurs.

$\mathrm{R}$ : What is needed for rusting? That is, why do you think that rusting occurs here?

$\mathrm{P}$ : Nail, iron is moisturized, then, there is oxygen. 
$\mathrm{R}:$ Where is the oxygen?

P: In the water

$\mathrm{R}$ : There is oxygen in the water. Do you mean the oxygen in the sturucture of the $\mathrm{H} 2 \mathrm{O}$.

$\mathrm{P}:$ Yes, in the structure of $\mathrm{H} 2 \mathrm{O}$.

$\mathrm{R}$ : From the oxygen in $\mathrm{H} 2 \mathrm{O}$.

P: Yes, I mentioned it.

R: OK. In the second situation, does oil have any impact?

P: No. Because the oil remains on the water.

$\mathrm{R}$ : OK. Does rusting occur in the moist air?

P: Yes, it occurs because of oxygen.

$\mathrm{R}$ : Where is the oxygen?

P: From the air.

$\mathrm{R}$ : In this situation, oxygen is from the air but in the first situation, it is from the water, isn't it?

P: Yes.

$\mathrm{R}$ : OK. Is rusting observed in the dry air?

P: observed

R: Why?

$\mathrm{P}$ : Because it is air, that is, there is oxygen.

$\mathrm{R}$ : You said again there is oxygen because of the air.

P: Yes.

R: OK. The air moisty or dry does not change anything.

P: Yes. There is oxygen.

Different from these students, two control group students (Kezban and Halide) had misconception about dry and moist air. Although they know that rusting is the reaction of the nail with oxygen, they thought that in dry air rusting does not occur because it does not include oxygen. For example, Halide told her ideas as follows.

Researcher (R): In question 25, there is a nail in dry air. Does rusting occur here?

Halide $(\mathrm{H})$ : Is there any Oxygen in dry air?

R: I don't know. What do you think about dry air? Do you think that there is any Oxygen in dry air?

$\mathrm{H}$ : Nitrogen only nitrogen. Nitrogen and other gases. Air without

Oxygen.

R: You said air without Oxygen.

$\mathrm{H}$ : Yes.

$\mathrm{R}$ : Does rusting occur?

$\mathrm{H}$ : No

$\mathrm{R}$ : Is there any redox reaction? 
H: If rusting doesn't occur, i.e., there isn't any change in the nail in dry air, there will not any redox reaction.

$\mathrm{R}$ : The nail will remain same. There isn't any change.

$\mathrm{H}$ : yes. No change occurs.

$\mathrm{R}$ : OK. What is the difference between moist and dry air?

$\mathrm{H}$ : Oxygen. That is, there is Oxygen in moist air.

Similarly, Kezban thought that dry air does not include oxygen because she thought that the source of the oxygen for rusting is water or moist. She explained her ideas as follow.

Researcher (R): Why doesn't rusting occur in dry air?

Kezban (K): I think there is no Oxygen in dry air.

$\mathrm{R}$ : Isn't there any Oxygen in dry air?

K: I think so. I don't know.

$\mathrm{R}$ : Is the source of Oxygen moist or water?

$\mathrm{K}$ : yes moist. There is water vapor in the moist.

$\mathrm{R}$ : Does Oxygen come from there?

$\mathrm{K}$ : Yes, I think that it is the source of Oxygen. I also thought like that for the situation occurs in the water.

$\mathrm{R}$ : Do you think that the water includes Oxygen?

$\mathrm{K}$ : Yes. I thought so.

Although most experimental group students knew that oxygen and water are needed for rusting, one of them (Gizem) thought that the nail represented in figure 1 in question 23 would rusted. Although she knew that there was no contact with oxygen due to oil, she thought that water include oxygen. Therefore, the nail was rusted. For the same situation, another experimental group student (Burcu) thought that oil does not prevent the system from oxygen therefore, it was rusted.

Regarding the protection of metals from corrosion, all experimental group students had sufficient understanding. For the question 22, all experimental group students thought that we could not protect the tank from corrosion when we used less reactive metal than iron. For explain, one of the experimental group students (Burcu) explained as follow.

Researcher (R): There is an iron fuel tank and it was connected to a metal to protect the tank from corrosion.

Burcu (B): Yes.

$\mathrm{R}$ : What should the characteristics of the metal be to protect the tank from corrosion? 
B: It should be more reactive than the iron.

R: Why?

B: Because it is oxidized, corroded instead of iron.

$\mathrm{R}: H 11 \mathrm{~m}$. OK. Which metal isn't the tank connected with? Which metal is not proper to protect the tank from corrosion?

B: A metal less reactive than iron is incommodious.

R: OK. Could you say the name of the metal by using the information given in the question?

B: These values are reduction potentials. We should turn them into oxidation potentials. Can I write?

$\mathrm{R}$ : Of course.

B: [trying to solve the question by setting the oxidation potential

values] Copper

R: Why do you select it?

B: Because its oxidation potential value is lower than others.

$\mathrm{R}$ : it is lower.

$\mathrm{B}$ : Yes. It is lower so copper is incommodious.

All experimental group students also explained how a zinc material given in the question 24 protects the iron pipe from corrosion correctly. For example, a correct expression from an experimental group student (Buket) is as follow:

Researcher (R): In question 24 there is an iron pipe under the soil and it is connected to a zinc material in order to protect the pipe from corrosion. In this system, how is the pipe protected from the corrosion? Why is a zinc material connected to the pipe?

Buket (B): [silence]

$\mathrm{R}$ : Does any change occur on the iron pipe in this system?

B: No, it doesn't.

R: Why?

B: Because it was done to protect it from rusting.

$\mathrm{R}$ : Why isn't it rusted?

$\mathrm{B}$ : Zinc is more reactive than iron.

R: him

$\mathrm{B}$ : Zinc reacts with oxygen since it is more reactive. Therefore, the iron pipe will be protected.

On the other hand, half of the control students (Aykut, Elif, Halide)

gave the correct answers for the question 22. However, only one of them (Aykut) could explain why the iron pipe can be protected from corrosion by connecting it to a zinc material. In other words, two of them could not apply 
their knowledge into another situation given in the question 24. For example,

Elif explained her ideas for question 22 as follow.

Researcher $(\mathrm{R})$ : In the question 22, there is a fuel tank made of iron. Elif (E): Yes.

$\mathrm{R}$ : We want to connect it with a metal in order to protect it from corrosion. What should the characteristics of the metal be?

E: It should be more reactive than this [iron]

R: H11m

E: Therefore, it reacts with oxygen instead of this [iron].

$\mathrm{R}$ : Regarding these metals [given in the question], which metal can we use?

E: It should be more reactive than the iron.

$\mathrm{R}$ : How do you decide which is more reactive?

E: Their values had been given.

R: Which values were given?

$\mathrm{E}$ : These were reduction potentials.

R: OK.

E: When I changed them to oxidation potentials, Magnesium had higher value. It has higher tendency to be oxidized. Therefore, we should connect the iron with magnesium.

R: OK. Which metals shouldn't be used?

E: The less reactive than iron. We shouldn't use copper.

R: Hi1m. What happens if we use copper?

$\mathrm{E}$ : This is rusted.

$\mathrm{R}$ : Do you mean that iron is rusted?

E: Fuel tank is rusted.

Although she knew that the more reactive metal is oxidized, she could not apply this knowledge into the situation given in the question 24. She explained her ideas as follow:

Researcher (R):There is a system including an pipe under the soil and connecting with a zinc material via a conducting wire.

Elif (E): to the iron.

$\mathrm{R}$ : to the iron, the iron pipe.

E: Yes.

$\mathrm{R}$ : What can you say about this system? What happens? Does any change occurs on the iron pipe? What is the function of the zinc.

E: Oxygen in the soil caused the zinc to be rusted.

$\mathrm{R}$ : If there wasn't zinc, if there was only iron, what would happen?

E: If it was under the soil, it would be rusted.

R: OK. Does connecting these [iron and zinc] change anything?

$\mathrm{E}$ : Can the function of this be protecting the iron from rusting?

$\mathrm{R}$ : How it can protect? 
E: Zinc is oxidized, iron isn't oxidized.

$\mathrm{R}$ : This system was already done to protect the iron from rusting.

E: OK.

R: How can we protect it? In other words, how does the zinc protect it?

E: Hi1m. I think the electrons which iron loses...

R: H11m

E: but zinc doesn't gain these electrons.

R: Do you have any idea?

E: I can't put forward an idea.

The half of the control group students (Kezban, Damla, Pelin) could not gave the correct answers for the question 22 and 24. For example, although Kezban thought that the zinc material prevented the iron pipe from rusting in the question 24, she could not explain how it prevented. She expressed her ideas as follow:

Researcher (R): In the question 24, there is a system in which an iron pipe is connected to a zinc material under the soil. If the iron wasn't connected to the zinc, would there be any change?

Kezban (K): Yes, there would be. The soil can be moist.

R: Hi1m. What would happen?

$\mathrm{K}$ : It would be rusted.

$\mathrm{R}$ : When we connect it to the zinc, will there be any change in the system?

K: Perhaps, zinc prevents it [iron] from reduction by oxygen.

$\mathrm{R}$ : prevent what?

$\mathrm{K}$ : That is, it prevents from rusting.

$\mathrm{R}$ : How does it prevent?

K: electrons... I don't know.

$\mathrm{R}$ : What happens to the iron when it is rusting?

$\mathrm{K}$ : it is reduced. Sorry, oxidized.

$\mathrm{R}$ : OK. How is it prevented from rusting when it is connected to the zinc?

$\mathrm{K}$ : Zinc prevents that oxygen caused the iron to be oxidized.

$\mathrm{R}$ : How does it prevent the iron from oxidation?

$\mathrm{K}$ : I don't know.

$\mathrm{R}$ : In the test, you answered that oxidation-reduction reaction occurs between the zinc material and the iron pipe.

$\mathrm{K}$ : Yes, I thought so. I think rusting of the iron is prevented.

$\mathrm{R}$ : The reaction occurs between zinc and iron.

K: yes. I don't know. I thought so.

$\mathrm{R}$ : OK. When this reaction occurs, doesn't any change occur in the iron?

$\mathrm{K}$ : I thought that no change occurs. 
$\mathrm{R}$ : Why is there no change?

$\mathrm{K}$ : I don't know.

In summary, almost all interviewees know that corrosion or rusting is a redox reaction occuring between metal and oxygen. However, all the experimental group students could explain which subject was oxidized or reduced during the corrosion or rusting correctly whereas half of the control group students could explain it. In addition, except one of them, experimental group students thought that oxygen and water are needed for rusting of iron while only one student in control group consider the effect of water during rusting process. Three control group students thought that only oxygen is needed for rusting of the nail. Some of them also thought that the oxygen for rusting is water or moist; dry air does not include oxygen. Regarding the protection of metals from corrosion, interviewees from the experiemental group had better understanding than those from the control group. For the question 22, all experimental group students thought that we could not protect the tank from corrosion when we used less reactive metal than iron. All experimental group students also explained how a zinc material given in the question 24 protects the iron pipe from corrosion correctly. On the other hand, while half of the interviewees from the control group (Aykut, Elif, Halide) gave correct answer for the question 22, only one of them (Aykut) could explain why the iron pipe can be protected from corrosion by connecting it to a zinc material in question 24. In other words, two of them could not apply their knowledge into another situation given in the question 24 .

\section{e) Understandings of Electrochemical Cells}

During the interview, students were asked an additional question different from the ECT, presented in the methodology part of this study. Students tried to answer whether the clock given in the system works or not by providing a reason. Four students in the experimental group (Buket, Gizem, Giray, Yaren) thought that the clock works because an oxidation-reduction reaction takes place in the system. During the interview they told how a redox 
reaction occurs in that system. They defined anode and cathode, and explained the flow of electrons in the system correctly. Although all of them know that a substance in the orange juice would be reduced, two of them (Giray and Yaren) could not specified that substance. In other words, two of them could not state that Hydrogen ion in the orange juice would be reduced in the cathode. For example, Yaren explained her ideas as follow:

Yaren (Y): when we reverse these reactions [given in the question] to have oxidation reaction of $\mathrm{Cu}$ and Magnesium. Then, we see that Magnesium have higher value for oxidation [standard potential]. Therefore, it is anode; copper is cathode.

Rsearcher (R): OK.

Y: Since there are all necessary materials I think that the clock works. Copper wire at the cathode does not reduce. It serves only as electrode. That is, it does not ionize. It is neither oxidized nor reduced.

R: Why?

$\mathrm{Y}$ : because that $\mathrm{Cu}$ wire was put at the cathode in order to provide electrons flow. I don't think that it reacts.

$\mathrm{R}$ : But you decide copper as cathode.

Y: Yes

$\mathrm{R}$ : At cathode, are there reduction?

Y: There are reduction at cathode but the substance in the liquid (solution) is reduced at the cathode.

$\mathrm{R}$ : What does the liquid contain?

$\mathrm{Y}$ : Orange juice, there is $\mathrm{H} 2 \mathrm{O}$ in the orange juice but no $\mathrm{H} 2 \mathrm{O}$. There is orange juice. Orange has acidic characteristics, doesn't it? I don't know but I thought like this.

$\mathrm{R}$ : Are reduction and oxidation necessary for battery to be worked?

Y: Yes

$\mathrm{R}$ : OK. You said that magnesium is oxidized at the anode but at the cathode the substance in the liquid is reduced, not copper.

Y: the substance in the solution is reduced.

$\mathrm{R}$ : Do you know which substance in the liquid is reduced?

Y: Which substances are there in the orange juice?

$\mathrm{R}$ : You thought that a substance in the orange juice will be reduced although you do not know what it is.

Y: Yes, generally in all electrochemical cells, the substance in the solution is reduced at the cathode not the electrode. The ion in the solution is reduced.

On the other hand, two students (Burcu and Ceren) stated that the clock does not work. Regarding the reasons of this situation, Burcu asserted that 
there are not any copper ions to be reduced in the system. Her response is presented below.

Researcher (R): Can we make the clock worked in this system?

Burcu (B): we can do it.

R: Why? How does it work? Which events occur?

B: Again, oxidation-reduction occurs.

R: Hirm

$\mathrm{B}$ : I think that there is an electron flow, it works.

$\mathrm{R}$ : Which substances are oxidized and reduced?

$\mathrm{B}$ : Magnesium is oxidized, copper is reduced.

$\mathrm{R}$ : Where does it go when oxidized?

$\mathrm{B}$ : Magnessium is oxidized to $\mathrm{Mg}+2$

R: h11m

$\mathrm{B}$ : Copper, $\mathrm{Cu}+2$ takes two electrons and it is reduced to $\mathrm{Cu}$, goes to zero.

$\mathrm{R}: \mathrm{OK}$. Is there $\mathrm{Cu}+2$ in the system?

$\mathrm{B}$ : No, there is not now.

$\mathrm{R}$ : Could $\mathrm{Cu}$ be reduced? or Is something else reduced? or Does not the clock work?

B: It could not. Therefore, the clock does not work.

R: Why does not it work?

$\mathrm{B}$ : Because we said that we do not have $\mathrm{Cu}+2$ to be reduced.

R: H11m

B: So I think the clock does not work.

$\mathrm{R}$ : Could something else in the medium be reduced?

$\mathrm{B}$ : There is not anything else in the medium.

The other student, Ceren, thought that the clock does not work since the system does not involve the components of an electrochemical cell. She explained her ideas as follow.

Researcher $(\mathrm{R})$ : In this system, there is a clock and its battery compartment connected to Magnessium strip and copper wire, which were immersed into the orange juice. Does the clock work in this system?

Ceren (C): not work.

$\mathrm{R}$ : Why do you think so?

$\mathrm{C}$ : It is an electrochemical cell. It is OK.

R: H11m

$\mathrm{C}$ : since there is one compartment here I think the clock does not work.

$\mathrm{R}$ : what do you mean saying compartment? Do you mean the container?

C: h1 h1

$\mathrm{R}$ : What should be there in an electrochemical cell? 
C: In an electrochemical cell, I need to have an anode part and a solution for it in order to provide current. Cathode provides the electron flow. There should be salt bridge to complete the circuit. Thus, ions flow to right place to complete the cell. However, I do not see these in this system.

Two of the students in control group thought that the clock works. However, one of them (Elif) could explain the reason of her answer correctly. The other student (Pelin) had a misconception about the oxidation states of the atoms in the copper wire. Elif's expression is presented below.

Researcher (R): In this sytem, there is an orange juice and the battery compartment of a clock connected to magnesium ribbon and copper wire. Does the clock work or not? What do you think?

Elif (E): I think it works because there is something giving electron and waiting electron.

R: h11m

E: theredore, I said it works. $\mathrm{Mg}$ is anode because its reactivity is higher and so it does not want to give an electron.

R: How did you decide that its reactivity was higher?

$\mathrm{E}: \mathrm{Cu}$ is already semi-noble metal.

R: hi1m OK.

E: since it does not give an electrons I identified like this.

R: OK.

$\mathrm{E}$ : and there is $\mathrm{H}+$. I thought that the electrons given by $\mathrm{Mg}$ goes to

copper

R:h11m

E: aaa..one minute.. $\mathrm{H}+$ also gains the electrons and h2 gases release here.

R: Why did you think copper was reduced at first?

E: because I thought copper receives the electrons but hydrogen receive them at first. No..one minute, hydrogen..copper..one minute..we assume this [Hydrogen] is zero doesn't we? Aaa hence, copper can receive the electrons.

$\mathrm{R}$ : there is the standard potential value for copper.

E: ....[silence]. Therefore it wants to gain the electrons if its reduction potential is higher. So, copper receives and cooper accumulates.

$\mathrm{R}$ : what is the reaction for copper, that is, reduction reaction?

$\mathrm{E}$ : now just a minute..for reduction $\mathrm{Cu}+2$ receives two electrons.

R: h11m

E: given by Mg. I shoul get the solid form [of copper]. That is, the mass of copper wire should increase.

$\mathrm{R}$ : Do we have $\mathrm{Cu}+2$ ?

E: hı1m. That is great $;$ there is no $\mathrm{Cu}+2$.

$\mathrm{R}$ : Does this reaction occur? 
E: It does not. Then, I think Hydrogen is formed. If there is no $\mathrm{Cu}+2$, hydrogen is formed compulsorily. There is anything else.

$\mathrm{R}$ : How is Hydrogen formed?

E: thre is Hyrdogen here. Copper wire keeps the electrons [relelases

from the $\mathrm{Mg}$ ]

R: h11m

E: in order not to be free Hyrogen receives the electrons

$\mathrm{R}$ : What happens when it receive electrons? What is the reaction?

E: There shoul be two H+

R: Hi1m

E: there are 2 electrons so $\mathrm{H} 2$ gases release.

R: OK.

In the control group, three students (Kezban, Halide and Damla)

thought that the clock does not work. According to two of them (Kezban and Halide), lack of a salt bridge in the system has been seen as the reason of this situation. For example, Kezban explained her ideas as follow:

Researcher (R): Does the clock work in this system? It immersed into orange juice.

Kezban (K): I thought there was Hyrodgen in the orange juice since it was acidic.

R: H11mm

$\mathrm{K}$ : Firstly, I realized that there is not salt here.

$\mathrm{R}$ : What do you mean when saying salt?

$\mathrm{K}$ : That is, salt bridge

$\mathrm{R}$ : There is no salt bridge.

$\mathrm{K}$ : there should be all elements for a battery to be worked. No salt bridge here.

$\mathrm{R}$ : salt bridge

$\mathrm{K}$ : We use it to neutralize ions. However, I do not know how I explain.

$\mathrm{R}$ : That is, salt bridge is needed for a system to be an electrochemical cell.

$\mathrm{K}$ : Yes

R: Hence, doesn't the clock work?

$\mathrm{K}$ : I think it does not work.

R: OK. Does an electrochemical cell occur in two seperated container?

$\mathrm{K}$ : I do not remember whether there should be two containers.

However, it is need to have salt bridge and all elements. To ensure these, concentration is needed. At least, there should be a solution.

$\mathrm{R}$ : what? For eaxamle, Is copper solution needed for copper?

$\mathrm{K}$ : Yes yes, because we deal with the ions in the solution.

R: Hi1m

$\mathrm{K}$ : I seem to remember. 
On the other hand, Damla thought that acidic medium due to the orange juice pose a problem for flow of electrons. Her expression is given below.

Researcher (R): In this question, there is a system. The battery compartment of a clock was connected to copper and magnesium wires which immersed into orange juice. Does the clock work in this system? Damla (D): [silence]. It does not work.

R: Why?

D: I think about the orange juice

R: Why? What do we need to make a battery? Shouldn' $t$ we use orange juice?

$\mathrm{D}$ : Orange juice is acidic.

R: h11mm

D: It is probably acidic.

R: OK.

D: I thought because it is not neutral environment

$\mathrm{R}$ : What do you mean saying neutral? the $\mathrm{pH}$ is not 7, isn't it?

D: Yes

$\mathrm{R}$ : Is the medium supposed to be neutral to make a battery?

D: The electrons....the orange juice is acidic.

R: h11mm

$\mathrm{D}$ : since it is acidic I thought that they might be collected in a different side. I know it is electically conductive.

R: h11mm

D: I thought there might be a problem about electron flow.

R: What kind of problem might there be? Do you have any idea?

D: uh..how was...

$\mathrm{R}$ : Does only orange juice has affected you think that the clock would not work?

D. Yes.

Finally, one of the students in the control group, Aykut, could not put forward an idea on the system. Since he did not know the ingredient of the orange juice he could not assert an idea about the chemicals oxidized and reduced. Hence, he did not have any idea whether the clock works or not.

To sum up, four interviwees from the experimental group thought that the clock works because an oxidation-reduction reaction takes place in the system. They defined anode and cathode, and explained the flow of electrons in the system correctly. However, two interviewees from the experimental group stated that the clock does not work since they thought that the system does not involve the components of an electrochemical cell such as two containers, salt 
bridge, or solution of the electrodes. On the other hand, only one interviewee from the control group thought that the clock works and explain the reason of it correctly. Other interviewees' responses indicated that they had insufficient understanding about the electrochemical cell. Similar to some interviewees from the experimental group, they thought that salt bridge is needed for an electrochemical cell. In addition, one of them thought copper wire could be reduced. Moreover, one interviewee from the control group thought that orange juice could pose a problem for flow of electrons due to its acidity.

\subsection{Students' Opinions about Case-based Instruction}

After the treatment, the opinions of the experimental group students about case-based instruction were determined through a feedback form (see Appendix I). Analysis of students' responses resulted in three main categories: students' description of the case-based instruction, students' perceptions about effectiveness of the case-based instruction, and difficulties that students encountered during the case-based instruction. Each category with representative responses of students is presented below.

\section{a) Students'descriptions of case-based instruction}

Analysis of students' responses to the feedback form revealed several main characteristics of the case-based instruction. Most of the students (61.8 $\%$ ) indicated that case-based instruction was an instruction based on real-life issues. For example, one of the students described the case-based instruction as "teaching the topic by giving examples related to the use of it in real life." Similarly, other students in the experimental group stressed the daily life issues in case-based instruction stating that "It also provides us to learn the relationship between course [chemistry] and daily life" and "In this model, while any knowledge or new concepts are being taught, theoretical knowledge is not given directly. Instead of this, learning occurs by relating the topic with daily life events." 
Another key element of the case-based instruction stated by the students was doing an activity/experiment (47.1\%). One of the students emphasized the importance of the activities in the case-based instruction as "Experiments and observations are hearth of the instruction." Another student thought that it was the experiments that help them learn the topic. Students also made connection between the cases and experiments, which can be concluded from the following excerpt: "We explained cases considering the results of experiments." Besides working on daily life issues and doing experiments, students pointed out working in a group (27.9\%) and dealing with a case (25 $\%$ ) as other characteristics of case-based instruction. The clearest feedback for this category was "[During the instruction], groups were formed. A text was distributed and then we discussed our opinions related to case given in the text with our teachers and did experiments." Another student also explained that "We worked in groups. The cases were discussed and experiments were done when necessary."

Some of the students concluded that case-based instruction was $a$ student centered method. For instance, it was stated that "It provided us opportunity to express our opinions and thought. " Likewise, some of them emphasized their effort during class to reach to the knowledge they need to explain the case. For example, one of the students wrote that "All students were actively involved in learning activities by observing and doing." Another student expressed that "This instruction made us use our knowledge, think on situations, and find answers by ourselves." These ideas supported students' view of case-based instruction as student-centered instruction.

In summary, the students viewed case-based instruction as a studentcentered teaching method including implementation of an activity/experiment, working in a group, and dealing with real-life examples.

b) Students' perceptions about effectiveness of case-based instruction

Students' opinions about the effectiveness of the case-based instruction were examined under the two categories: learning and enjoyment. Regarding 
learning, $91 \%$ of the students thought that case-based instruction was effective in terms of enhancing their learning in chemistry. They stated that CBI provided visual materials, experiments, and daily life examples and thus they understood the subject better. Moreover, they stressed that their learning was enduring when they learned the topics in this way [through case-based instruction]. For example, one of the students found real-life events as useful for his learning: "It is effective because real life events are more realistic than the examples given in the previous lessons. We understood well." For the other student, both daily life examples and experiments were beneficial as it can be realized from her idea: "Learning theoretical knowledge through daily life examples enhances our learning. Learning by observing and conducting experiments by ourselves is effective and permanent." Regarding the helpfulness of the visual materials on chemistry learning, it was stated that case-based instruction is an effective method because visual examples/materials are permanent/long-lasting in the mind. Learning through visuals provides meaningful learning instead of rote learning. When we see similar situations, we can make a logical interpretation by figuring out the previous case in our minds.

In addition, students expressed their ideas about the effectiveness of both daily life events and visuals on chemistry learning by comparing their previous instruction with the case-based instruction: "Beforehand, knowledge was presented directly not by cases and therefore, understanding chemistry was quite difficult. Now, both observing and relating the topics with real-life events are more helpful for us to understand the topic." They emphasized the benefit of cases for their learning since the cases help them realize the importance of chemistry learning:

Beforehand, when formulas and names of the compounds were written on the board, none of the examples emerged in my mind. There was no explanation about why we were doing/learning this. However, this method make chemistry more illuminating for me since it teaches chemistry by providing cases and using visual materials. It teaches not only formulas for university exam but also chemistry which we need in our lives. 
Furthermore, some students stated that they learned the chemistry topics easily through case-based instruction. For example, one of the students started to think that chemistry was not difficult any more. S/he stated that "We primarily understood that chemistry can be learned." On the contrary, a few students (9\%) thought that the case-based instruction was ineffective on their learning because of not being used to be taught by case-based instruction and doing activities without knowing the topic. For example, one student stated that "In my opinion, case-based instruction is not an effective method since the instruction by which we were taught for years required rote learning (and we want to get knowledge directly)." Similarly, another one expressed that "casebased instruction is not effective. In my view, ordinary instructions are more effective and easier."

Regarding enjoyment, $40.3 \%$ of the students indicated that the casebased instruction was interesting and enjoyable. For instance, one student stated that "Chemistry lessons became more lively and less boring due to experiments and reading texts/cases. I learned chemistry in this class better than in previous lessons." Similarly, another student thought that "Chemistry became more enjoyable through case-based instruction." Generally, students described the case-based instruction as an amusing, enjoyable, and interesting. They also expressed that "It increases our interest to chemistry since it answers the question: where do we use this chemistry knowledge in our lives?" One of the reasons why students find case-based instruction enjoyable is realizing the relationship between chemistry and real life. For instance, one of the students stated that "Lessons were more enjoyable. My interest to chemistry increased. I performed some experiments at home. I tried to clean my tarnished silver ring (lemon juice, carbonate) and I succeeded. I liked it very much. I understood that chemistry is embedded in our lives." Another student also expressed similar idea: "Feature about case-based instruction that I liked most was its emphasis on the relationship between chemistry and our lives; and thus we understand the importance of chemistry in our life. Thus, my interest to 
chemistry learning increased." Some students highlighted that their attitude towards chemistry increased as it can be concluded from the following statement: "Learning the place of chemistry in our lives was the feature that I liked most. Case-based instruction is more interesting than the instruction in the previous chemistry lesson. I liked chemistry a bit more." Students also enjoyed active learning process: "I enjoyed the lesson because the teacher and the students draw conclusions together during the lesson. In addition, making us think and draw conclusion based on our previous knowledge were good."

c) Difficulties students encountered during the case-based instruction

More than the half of the students $(67.6 \%)$ stated that they did not encounter any difficulties during the implementation of case-based instruction while some students (32.4\%) expressed that they had some difficulties during case-based instruction. Those who reported that they had difficulties pointed out several factors as problematic to them. For example, some students indicated working in a group as a problem: "working in a group was not for me, I prefer individual working, I am more concentrated when I study alone than when I work in a group". Some of them stated that they had difficulty in interpreting the cases and answering the related questions after the case. Regarding this issue, one of the students thought that "it was difficult to give an answer to the questions without knowing the topic." Similarly, another student stated that "We had difficulties since we didn't have sufficient knowledge about the cases (since questions were asked before the topic was taught us). If the cases were given before the lesson (e.g., 2 days before the lesson), it would be very good." In addition, some of the students explained that they had difficulty in adopting the method since they were not used to be taught by case-based instruction as can be seen in one of the students' excerpt:

In my opinion, previous lessons were more effective. From primary school to now, teachers transfer knowledge to us directly without conducting any experiments. Learning is easier since we were accustomed to learn in that way. I had difficulty in interpreting cases and observations during experiments.

Similarly another student considered the same experience as problematic: 
I certainly had difficulties because I hadn't been taught with this method before. Since I didn't know what I would do exactly I found it difficult at the beginning. Probably, I am not used to be taught by case-based instruction. Therefore, I couldn't adopt myself to this method. I thought that I didn't learn well. However, I overcame my deficiencies by my own effort.

\subsection{Summary of Results}

To sum up, the analysis of MANOVA results for pre-test scores demonstrated that there was no a statistically significant mean differences between experimental and control groups in terms of students' prior knowledge about electrochemistry concepts, attitude toward chemistry, motivation to learn chemistry and chemistry self-efficacy beliefs at the beginning of the study. On the contrary, the analysis of MANOVA for post-test scores revealed that students in the experimental group gained significantly better understanding of electrochemistry concepts than those in the control group. In addition, there were significant mean differences between experimental and control group students with respect to attitude toward chemistry and intrinsic motivation to learn chemistry at the end of the study. Moreover, case-based instruction had no significant effect on students' perceptions regarding relevance of learning chemistry to personal goals, chemistry self-efficacy for cognitive skills and self-efficacy for chemistry laboratory when compared to traditional instruction.

The interview analysis also indicated that students exposed to casebased instruction demonstrated better understanding of electrochemistry concepts than those followed traditional instruction.

The analysis of students' responses on the Feedback Form of Casebased Instruction indicated that case-based instruction was found as effective in terms of enhancing students' learning in chemistry and their enjoyment in learning chemistry. Although, more than the half of the students stated that they did not encounter any difficulties during the implementation of case-based instruction while some students expressed that they had some difficulties 
during case-based instruction such as working in a group and adopting to casebased instruction, a new instructional method. 


\section{CHAPTER 6}

\section{DISCUSSION AND IMPLICATION}

There are three sections in this chapter; these sections begin with a discussion and interpretations of the results. Secondly, implications of the results will be given. Finally, suggestions of this study for future research will follow.

\subsection{Discussion of Results}

The purpose of this study was to explore the effect of case-based instruction on $11^{\text {th }}$ grade high school students' understanding of electrochemistry concepts, attitude toward chemistry, motivation to learn chemistry, and chemistry self-efficacy beliefs compared to traditional chemistry instruction. For this aim, the students in the experimental group were instructed with case-based instruction and those in the control group were taught traditionally over a period of seven weeks. MANOVA results indicated that the students who were instructed through case-based instruction acquired electrochemistry concepts better; developed more positive attitudes toward chemistry; and improved their motivation more than the students who were taught with traditional instruction. However, results demonstrated no significant effect of case-based instruction on students' chemistry self-efficacy beliefs compared to traditional chemistry instruction.

Students who were taught by case-based instruction demonstrated significantly higher scores on the electrochemistry concept test than those who were taught traditionally. In other words, this study indicated that case-based instruction was more effective than traditional instruction in terms of 
promoting meaningful understanding of electrochemistry concepts. Therefore, the current study provides further empirical support for the previous studies in science education showing the effectiveness of the case-based instruction over traditional instruction (Cakir, 2002; Cam, 2009; Ozkan \& Azar, 2005; Rybarczyk, et al., 2007; Saral, 2008; Yalcinkaya, 2010). The probable underlying reasons why the case-based instruction was effective on students' understanding of electrochemistry concepts can be related characteristics of the instruction. Leonard (2000) pointed out that when a student is actively involved (physically, emotionally, and mentally) in a learning process, s/he will have a deeper understanding of concepts and retain that understanding longer than when the learning experience is passive. In the literature, it is clearer to science educators that active learning environments based on constructivist approach have crucial impact on students' meaningful learning (Barron-DarlingHammond, 2008; Duit \& Treagust, 1998; Mayer, 1999). In the experimental group of this study, the case-based instruction created an active learning environment that involved students in solving and examining real-world problems in small groups with guided instruction. Small group and whole class discussions directed students to think on the situations and encouraged them to express their ideas. Thus, the case-based instruction offered students to construct their knowledge in an authentic and active learning environment. On the other hand, students in the control group were passive during traditional chemistry instruction. The knowledge transmitted from the teacher to the students. As a result, the active learning environment during the case-based instruction may have provided students with better understanding of electrochemistry concepts compared to traditional instruction.

Furthermore, dealing with real-life examples might have role in the difference between the experimental group and control group students' acquisition of the concepts. The learning tasks that emphasize relevance and meaningfulness of the content promote students interest in learning and thus enhance students' learning (Kortland, 2007). In this study, the content of cases 
reflected daily life situations which helped students gain an insight into the role of chemistry in their life; thus, see the importance and relevance of it for themselves. Students in the experimental group also expressed their ideas on the feedback form stressing that visual materials, experiments, and daily life examples were helpful in learning chemistry because those materials allowed them to create link to real life instead of simple memorization. In addition, use of cases during instruction helped them realize the importance of chemistry learning. Indeed, electrochemistry is one of the chemistry subjects which were perceived as difficult by students (Finley, Stewart \&Yarroch, 1982; Johnstone, 1980; Butts \& Smith, 1987; Soudani, et al., 2000). Soudani, et al. (2000) proposed that one of the factors responsible for students' difficulties in electrochemistry was their unawareness of the relevance of chemistry with their life and environment. Students generally see the scientific facts, definitions, and formulas as school knowledge and memorize them just to pass their chemistry exams. They do not see the importance and relevance of learning chemistry concepts for themselves (Hutchinson, 2000). However, for meaningful learning it is suggested that learning material should be relevant to students' lives; therefore, students view the content they are learning as useful and learn the topic more meaningfully (Ames, 1992; Glynn, et al., 2007; Zusho, et al., 2003). Regarding this point, the present study clearly indicates that the case-based instruction provides an effective learning environment that increase students' attention and helps them see the relevance and importance of chemistry to their lives rather than merely memorizing a prescribed body of knowledge, and thus, enhances their understanding of the topic.

The findings from interviews also suggest that students instructed with case-based instruction had better understanding of electrochemistry concepts compared to ones taught traditionally. Although some students from the control group answered the questions on the Electrochemistry Concept Test correctly, they could not provide a sufficient explanation for their answers during the interviews. This indicates that they answered the questions correctly without 
meaningful understanding during the post-test. Moreover, it was seen that although they had some theoretical knowledge about corrosion and protection of metals from corrosion, they could not apply their knowledge into another situations, especially contextual questions. Students in the experimental group were more successful in transfering their knowledge about electrochemistry to different situations. This indicates that case-based instruction was more effective in helping students to learn more meaningfully than traditional instruction. The results of the interviews also indicated that students' prior learning affected their achievement in electrochemistry. Although students knew oxidation and reduction concepts, some of them were insuccesful in balancing redox reactions and identification of chemical substances oxidized and reduced in a redox reaction due to their insufficient or inaccurate knowledge of periodic system.

The present study also provided empirical evidence for the effectiveness of the case-based instruction on not only chemistry learning but also on the development of positive attitudes toward chemistry as a school subject. This result is parallel with the findings of other studies which utilized the case-based instruction to promote students' attitudes toward science such as Cam (2009), Cakir (2002), Ozkan and Azar (2005), Gallucci (2007) and Yalcinkaya (2010). In addition, analysis of students' written responses to the feedback form also supported this result: The students instructed with the casebased instruction reported positive opinions about the chemistry lesson and chemistry learning in the Feedback Form of case-based instruction and they found chemistry lessons more interesting and enjoyable via case-based instruction when they compared to their previous traditional chemistry instructions. In addition, they pointed out that realizing the importance and the relevance of chemistry to their lives increased their interest to learn chemistry. This finding supported that relevance and authenticity of the topics being studied is one of the factors influencing students' attitudes toward science as stated by Raved and Assaraf (2011) and Movahedzadeh (2011). In general, the 
findings of the present study supported to previous studies revealed that students find case-based instruction as realistic, challenging, interesting, enjoyable, and encouraging for learning (Ayyildiz \& Tarhan, 2012; Bridges \& Hallinger, 1999; Dori \& Herscovitz, 1999; Herreid, 2006; Jones, 1997; Mayo, 2002; 2004; Naumes \& Naumes, 2006; Smith \& Murphy, 1998; Wassermann, 1994). The case-based instruction provided opportunities for students to experience and practice real life situations and thus, to perceive the relevance of science. Since chemistry is seen as a boring subject and irrelevant to life (Hutchinson, 2000; Soudani, et al., 2000), the case-based instruction is more likely to contribute to the increase in student interest in chemistry and improve their views about relevance of chemistry to their life, which enhances their attitudes toward chemistry. The literature indicated that active participation of students in learning process is also main characteristic of effective instructions on promotion of positive attitude toward science (Oliver-Hoyo \& Allen, 2005; Wong, et al., 1997; Fouts \& Myers, 1992). Since students instructed with the case-based instruction were provided opportunities to be actively involved in and take responsibility for learning, they might have had more positive attitudes toward chemistry compared to students taught traditionally.

Regarding the motivation variable, the students instructed by the casebased instruction had higher intrinsic motivation to learn chemistry than those were taught traditionally after the treatment as concluded from both MANOVA results and written responses. However, the results of the study demonstrated no significant effect of case-based instruction on students' perceptions regarding relevance of learning chemistry to personal goals compared to traditional chemistry instruction. These findings are inconsistent with some of the results of previous studies conducted in science education. For example, Yalcınkaya (2010) investigated the effectiveness of case-based instruction on students' motivation in chemistry. The results of her study revealed that there was no significant mean difference in students 'perceived intrinsic motivation. Similarly, the study of Saral (2008) detected no significance mean difference in 
students' perceived intrinsic motivation in biology after the case-based instruction although their scores were higher than those of students taught traditionally. Opposite to those results, the present study provides empirical evidence for the effectiveness of case-based instruction on students' motivation to learn science, particularly chemistry. The case-based instruction provided opportunities students to deal with cases involving authentic examples. This characteristic of case-based instruction may have increased students' curiosity and interest, thus students in the experimental group were more inherently motivated to learn chemistry than those in the control group. Moreover, Herreid (2005) stated that case-based instruction makes the classroom environment vigorous and more engaging for than traditional instruction because students are involved in trying to put ideas into their own words while studying on cases. Students are intrinsically motivated when they engage in activities (Wigfield, Eccles, \& Rodriguez, 1998). In the literature, in addition to relevance of the content to one's life, encouraging students' active participation in learning process through using small group work activities or leading discussions is seen as useful for promoting motivation to learn (Glynn \& Koballa, 2006; Kusurkar, Croiset, \& Ten Cate, 2011; Vaino et al., 2012; Linnenbrink \& Pintrich, 2002; Ryan \& Deci, 2000). Due to the fact that students instructed with case-based instruction worked in small groups and discussed their ideas with group members and whole class this kind of learning environment might have increased their intrinsic motivation at the end of the treatment.

As previously stated, the results of the study demonstrated no significant effect of the case-based instruction on students' perceptions regarding relevance of learning chemistry to personal goals compared to traditional chemistry instruction. In other words, there were no significant difference between experimental and control groups in terms of their willingness to engage in chemistry learning for reasons such as their future careers, goals, and lives. However, it is interesting to note that students' 
perceptions about relevance of learning chemistry decreased after receiving traditional instruction for the topic of electrochemistry while increasing after the case-based instruction. One of the reasons for non-significant result might be the limited implementation period of the case-based instruction. Seven weeks might not be enough to change students' perceptions about relevance of learning chemistry to their personal goals significantly. In addition, implementation of case-based instruction was limited to unit of electrochemistry in high school chemistry curriculum. Therefore, it is difficult to consider all students future goals and careers while designing the case-based instruction only on the topic of electrochemistry. In this study, topics of the cases differ from each other. Therefore, the topics of the cases might not have been related to some students' future goals or one related topic might not be sufficient for students to relate chemistry learning to their future careers. Designing the case-based instruction based on students interest and future goals might be more effective on promoting their perceptions regarding relevance of learning chemistry to their personal goals. In addition, having longer implementation period of case-based instruction on different topics of chemistry may yield greater change in students' perceptions about relevance of learning chemistry to personal goals.

Regarding the last affective variable of the study, no significant mean difference was detected in both students' self-effficacy for cognitive skills and chemistry laboratory across the experimental and control groups after the treatment. However, it is worth to say that regarding self-efficacy for cognitive skills and chemistry laboratory scores of students instructed with the casebased instruction were higher than those instructed traditionally. One of the possible reasons for this result might be related to the duration of the treatment. The implementation was restricted to seven weeks. Since many authors have argued that beliefs are highly resistant to change (Bandura, 1986; 1997; Pajares, 1992) the limited period of implementation of the case-based instruction might not be sufficient for the students to improve their chemistry 
self-efficacy beliefs. Having longer time for implementation of the case-based instruction to various chemistry topics may result in greater changes on students' chemistry self-efficacy. Moreover, although students in the experimental group did some experiments, observed demonstrations, reported and discussed their result during the case-based instruction, the instruction was not completely based on laboratory activities. Therefore, this might be reason for not determining a significant rise in the students' self-efficacy for chemistry laboratory.

Regarding the nature of chemistry instruction, making the learning chemistry topics more relavant to students' lives (Raved \& Assaraf, 2011), encouraging active involvement of students in learning process (Fouts \& Myers, 1992; Oliver-Hoyo \& Allen, 2005; Wong, et al., 1997), and providing small group works (Kose et al, 2010; Shibley \& Zimmaro, 2002; Thompson \& Soyibo, 2002) were among the characteristics of effective chemistry instruction for promoting students' learning, attitudes toward chemistry and motivation to learn chemistry. In this study, implementation of case-based instruction including real-world application, group work and discussion was found to be more efficient over traditional instruction. In other words, synergistic effect of dealing with real-life events, working in a group, and discussion enhanced students' learning, attitudes toward chemistry, and motivation to learn chemistry. However, it cannot be known which particular charateristics of case-based instruction (real-life context, group work, and discussion or laboratory experiments) had influenced students' learning, attitudes toward chemistry, and motivation to learn chemistry. Therefore, in the future studies, some of the charateristics of the case-based instruction such as group work could be isolated and their influence on students' learning, attitudes toward chemistry, and motivation to learn chemistry could be examined.

In light of the results, it is believed that this study will contribute to the science education literature. In conclusion, this study confirms and broadens the findings related to effectiveness of relatively new method, case-based 
instruction, on students learning in the context of chemistry education. Casebased instruction provides improvement not only in cognitive domain but also in affective domain since this study provides the body of evidence that casebased instruction influences students' attitude toward chemistry and motivation to learn chemistry. Moreover, results of this study are likely to broaden knowledge of science educators as what kind of instructional strategies can enhance students' meaningful chemistry learning, attitude toward chemistry, and motivation to learn chemistry.

\subsection{Implications}

This study has several implications for chemistry educators and researchers. In the literature, it is clear that the nature of chemistry instruction has an important role in promoting students' meaningful learning of chemistry. Instructions based on constructivist approach emphasizing active learning are more effective in promoting meaningful learning than traditional instruction. For the purpose of effective chemistry teaching, although many researchers have designed various instructional strategies providing active learning environment and explored their effects on students' learning, new teaching methods are still among chemistry educators' field of interest. Case-based instruction, a student-centered method, encourages students to involve in learning process actively through working on cases. Based on the findings presented in this study, case-based instruction, relatively new method in chemistry education, offers a more effective learning environment than traditionally designed chemistry instruction. Therefore, this study can serve as a guide to chemistry teachers in designing effective chemistry instruction. Chemistry teachers can apply case-based instruction in their class to promote meaningful learning on the topic of electrochemistry.

Chemistry educators do not only deal with students' performance in cognitive domain but also emphasis on shaping students' affective domain. Affective variables such as attitude and motivation have impact on students' 
learning. Chemistry lessons should be enjoyable and interesting for students to increase their attitude toward chemistry and motivation to learn chemistry. In light of the findings of this study, chemistry teachers can use case-based instruction in their classes to improve students' attitude toward chemistry and their intrinsic motivation to learn chemistry. Due the fact that students found real-life events presented during the case-based instruction as effective for their learning, enjoyable and interesting, chemistry teachers should enriched their instructions with real-life context to improve students' learning, attitude toward chemistry and motivation learn chemistry. In other words, chemistry teachers should link chemistry with students' lives to improve their learning and motivate them to learn chemistry. Moreover, based on the students ideas about case-based instruction, chemistry teachers might benefit from experiments, visual materials and group works during their instructions for an effective learning environment.

Finally, researchers might explore the effects of case-based instruction on students' learning in other chemistry subjects to broaden findings related to effectiveness of case-based instruction.

\subsection{Recommendations}

These are some recommendations for further research:

- A similar study can be replicated with a larger sample size and in different schools to increase generalizability of the results regarding the effectiveness of case-based instruction.

- A similar study can be carried out at different grade level and on different topics of chemistry to investigate the effectiveness of casebased instruction.

- The impact of case-based instruction can be tested in other fields of science.

- The effectiveness of case-based instruction on other variables such as higher order thinking and problem solving skills can be investigated for 
a further study in order to extend the understanding of the effectiveness of case-based.

- Longitudinal studies can be conducted in order to explore the effect of case-based instruction on students' chemistry learning, attitude toward chemistry, motivation to learn chemistry and chemistry self-efficacy beliefs.

- Further studies can investigate the long terms effect of case-base instruction on students' learning.

- Further studies can investigated the effectiveness of the ways of using cases such as in-class activity, out of class assignment, or an online assignment.

- Further studies can compare the effectiveness of working in a small group to working individually during case-based instruction.

- Finally, qualitative studies can be conducted to investigate the effectiveness of case-base instruction on attitudes toward chemistry and motivation to learn chemistry. 


\section{REFERENCES}

Acar, B., \& Tarhan, L. (2008). An active learning application based on constructivism for the subject of "acid and bases" in high school chemistry lesson. Doctoral Dissertation, University of Dokuz Eylül.

Adali, B. (2005). Effect of case-based method on 5th grade elementary school students academic achievement and attitudes toward science while teaching "viruses, bacteries, fungi and protists" topic. Unpublished master's thesis, Mustafa Kemal University, Hatay.

Adesoji F. A., Raimi, S. M. (2004). Effects of enhanced laboratory instructional technique on senior secondary students' attitude toward chemistry in Oyo Township, Oyo State, Nigeria. Journal of Science Education. and Technology, 13(3), 377-385.

Aikenhead, G. (2003, August). Review of research on humanistic perspectives in science curricula. Paper presented at the European Science Education Research Association (ESERA) 2003, Noordwijkerhout, The Netherlands. Retrieved March 24, 2013, from http://www.usask.ca/education/people/aikenhead/ESERA_2.pdf.

Altinok, H. \& Un-Acikgoz, K. (2006). İşbirlikli öğrenme ve kavram haritalamanın fen bilgisi dersine yönelik tutum üzerindeki etkileri. Hacettepe Üniversitesi Ë̆itim Fakültesi Dergisi, 30, 21-29.

Ames, C. (1992). Classrooms: Goals, structures, and student motivation. Journal of Educational Psychology, 84, 261-271

Anderson, C. W., \& Lee, O. (1997). Will Students Take Advantage of Opportunities for Meaningful Science Learning?. ,. The Phi Delta Kappan, 78(9), 720-724.

Anderson, C. W., \& Smith, E. L. (1987). Teaching science. In V. RichardsonKoehler (Ed.),Educators' handbook: A research perspective (pp. 84111). New York: Longman 
Andrew, S. (1998). Self-efficacy as a predictor of academic performance in science. Journal of Advanced Nursing, 27, 596-603.

Arbuckle, J. L. (2012). IBM SPSS Amos 21 User's Guide. Amos Development Corporation.

Ausubel, D. P. (1968). Educational psychology: A cognitive view. New York: Holt, Rinehart \& Winston.

Aydeniz, M. \& Kaya E. (2012). Understanding the factors that impact Turkish high school students' attitudes towards science and their academic performance in science. Journal of Turkish Science Education. 9(2), 2548.

Ayyildiz, Y. \& Tarhan, L. (2013). Case study applications in chemistry lesson: Gases, liquids, and solids. Chemistry Education Research and Practice, $14,408-420$.

Ayyildiz, Y., \& Tarhan, L. (2012). Effect of case studies on primary school teaching students' attudes toward chemistry lesson. Hacettepe University Journal of Education, 43, 62-70.

Bandura, A. (1977). Self-efficacy: Toward a unifying theory of behavioral change. Psychological Review, 84(2), 191-215.

Bandura, A. (1986). Social foundations of thought and action: A social cognitive theory. Englewood Cliffs, NJ: Prentice Hall.

Bandura, A. (1994). Self-efficacy. In V. S. Ramachaudran (Ed.), Encyclopedia of human behavior (Vol. 4, pp. 71-81). New York: Academic Press.

Bandura, A. (1997). Self-efficacy: The exercise of control. New York: W. H. Freeman.

Barron, B., \& Darling-Hammond, L. (2008). Teaching for meaningful learning: A review of research on inquiry-based and cooperative learning. In Powerful learning: What we know about teaching for understanding. In L. Darling-Hammond, B. Barron, D. Pearson, A. Schoenfeld, E. Stage, 
T. Zimmerman, G. Cervetti, \& J. Tilson (Eds.), Powerful learning: What we know about teaching for understanding (pp. 11-70). San Francisco: Jossey-Bass.

Barton, B. H. (2008). A tale of two case methods. Tennessee Law Review, 75(3), 233-50.

Billett, S. (1998). Appropriation and ontogeny: identifying compatibility between cognitive and sociocultural contributions to adult learning and development. International Journal of Lifelong Education, 17(1), 21-34

Bridges, E. M., \& Hallinger, P. (1992). Problem-based learning for administrators. Eric Clearinghouse on Educational Management, University of Oregon.

Briscoe, C., \& LaMaster, S. U. (1991). Meaningful learning in college biology through concept mapping. The American Biology Teacher, 214-219.

Britner, S. L., \& Pajares, F. (2001). Self-efficacy beliefs, motivation, race, and gender in middle school science. . Journal of Women and Minorities in Science and Engineering, 7, 271-285.

Britner, S. L. \& Pajares, F. (2006). Sources of science self-efficacy beliefs of middle school students. Journal of Research in Science Teaching, 43(5), 485-499.

Brophy, J. (1998). Motivating students to learn. Boston: McGraw Hill.

Brown, K., Commandant, M., Kartolo, A., Rowed, C., Stanek, A., Sultan, H., \& Wininger, V. (2011). Case based learning teaching methodology in undergraduate health sciences. Interdisciplinary Journal of Health Sciences, 2(2), 47-65.

Bushman, J. B. (2010). Corrosion and cathodic protection theory. USA:

Bushman \& Associates, Inc, Medina. 
Butts, B., \& Smith, R. (1987). HSC chemistry students' understanding of the structure and properties of molecular and ionic compounds. Research in Science Education, 17(1), 192-201.

Byrne, B. M. (2010). Structural equation modeling with Amos: Basic concepts, applications, and programming (2nd ed.). New York, NY: Taylor and Francis Group.

Cakir, O. S. (2002). The development, implementation and evoluation of a case-based method in science education. Unpublished doctoral dissertation, Middle East Technical University, Ankara.

Cam, A. (2009). Effectiveness of case-based learning instruction on students' understanding of solubility equilibrium concepts. Unpublished doctoral dissertation, Middle East Technical University, Ankara.

Cameron, A. (2004). Kurtosis. In M. Lewis-Beck, A. Bryman, \& T. Liao (Eds.), Encyclopedia of $\quad$ social science research methods. (pp. 544545). Thousand Oaks, CA: SAGE Publications, Inc. doi: http://dx.doi.org/10.4135/9781412950589.n467

Capa-Aydin, Y., \& Uzuntiryaki, E. (2009). Development and psychometric evaluation of the high school chemistry self-efficacy scale. Educational and Psychological Measurement, 69(5), 868-880.

Cetin-Dindar, A., \& Geban, O. (2010). The Turkish Adaptation of the Science Motivation Questionnaire. In M. F. Tasar, \& G. Cakmakci (Eds.), Contemporary science education research: pre-service and in-service teacher education (pp. 119-128). Ankara, Turkey: Pegem Akademi.

Ceyhun, I., \& Karagolge, Z. (2005). Chemistry students' misconceptions in electrochemistry. Australian Journal of Education in Chemistry, 65, 2428.

Challen, P., \& Brazdil, L. C. (1996). Case studies as a basis for discussion method teaching in introductory chemistry courses. The Chemical Educator, 1(5), 1-13. 
Cheng, V. K. (1995). An environmental chemistry curriculum using case studies. Journal of Chemical Education, 72(6), 525-527.

Ciftlik, S., Handiri, I., Beyhan, M., Akcil, A. U., Ilgar, M., \& Gonullu, M. T. (2009). Elektrikli ve Elektronik Atıkların (E-Atık) Yönetimi, Ekonomisi ve Metal Geri Kazanım Potansiyeli Bakımından Değerlendirilmesi. Türkiye' de Katı Atık Yönetimi Sempozyumu (TÜRKAY), Yıldız Teknik Üniversitesi, İstanbul.

Cliff, W. H. (2006). Case study analysis and the remediation of misconceptions about respiratory physiology. Advances in Physiology Education, 30, 215-223. doi:10.1152/advan.00002.2006

Cliff, W. H., \& Wright, A. W. (1996). Directed case study method for teaching human anatomy and physiology. Advances in Physiology Education, 15(1), 19-28.

Conant, J. B. (1957). Harvard Case Histories in Experimental Science. Cambridge: Harvard University Press.

Coppola, B. P. (1996). Progress in practice: teaching and learning with case studies. The Chemical Educator, 1(4), 1-13. doi:10.1333/s00897960050a

Cornely, K. (1998). Use of case studies in an undergraduate biochemistry course. Journal of Chemical Education, 75(4), 475-478.

Creswell, J.W. (2007). Qualitative inquiry and research design: Choosing among five approaches (2nd ed.). Thousand Oaks,. CA: Sage.

Crocker, L., \& Algina, J. (1986). Introduction to Classical and Modern Test Theory. Philadelphia: Harcourt Brace Jovanovich College Publishers.

Cunningham, G. K. (2005). Assessment in the classroom: constructing and interpreting texts. London: The Falmer Press.

De Jong, O. \& Taber, K. S.(2007) Teaching and learning the many faces of chemistry. In Abell, S. K. and Lederman, N. G. (eds), Handbook of 
Research on Science Education (pp.631-652). Lawrence Erlbaum Associates.

De Jong, O., \& Treagust, D. (2002). Teaching and learning of electrochemistry. In Gilbert J. K., de Jong O., Justi R., Treagust D. F., and van Driel J. H.(eds.) Chemical education: Towards research-based practice (pp. 317-337). Dordrecht, The Netherlands: Kluwer.

Dillon, J. (2009). On scientific literacy and curriculum reform. International Journal of Environmental \& Science Education, 4(3), 201-213.

Dori, Y.J., \& Herscovitz, O. (1999). Question posing capability as an alternative evaluation method: analysis of an environmental case study. Journal of Research in Science Teaching, 36(4), 411-430.

Driscoll, M. P. (2005). Psychology of learning for instruction (3rd ed.). Boston: Allyn and Bacon.

Duit, R., \& Treagust, D. F. (1998). Learning in science - From behaviourism towards social constructivism and beyond. In B. J. Fraser, \& K. Tobin (Eds), International Handbook of Science Education (pp. 3-25). Dordrecht, The Netherlands: Kluwer Academic Publishers.

Dunlap, J. C. (2005). Problem-based learning and self-efficacy: How a capstone course prepares students for a profession. Educational Technology Research and Development, 53(1), 65-83.

Dupuis, R. E., \& Persky, A. M. (2008). Use of case-based learning in a clinical pharmacokinetics course. American journal of pharmaceutical education, 72(2), 29-.

Dweck, C. S. \& Leggett, E. L. (1988). A social-cognitive approach to motivation and personality. Psychological Review, 95, 256-273.

Ekici, F. (2007). Yapılandırmacı yaklasıma uygun 5E ögrrenme döngüsüne göre hazırlanan ders materyalinin lise 3. Sinıf öğrencilerinin yükseltgenmeindirgenme tepkimeleri ve elektrokimya konularını anlamalarına etkisi. Unpublished Master Thesis, Gazi University, Ankara. 
Ertmer, P. A., \& Dillon, D. R. (1998). "Shooting in the dark" vs. "Breaking it down": Understanding students' approaches to case-based instruction. International Journal of Qualitative Studies in Education, 11, 605-622.

Ertmer, P. A., \& Newby, T. J. (1996, Autumn). Students' responses and approaches to case-based instruction: the role of reflective selfregulation. American Educational Research Journal, 33(3), 719-752.

Ertmer, P. A., \& Russell, J. D. (1995). Using case studies to enhance instructional design education. Educational Technology, 35(4), 23-31.

Ertmer, P. A., Newby, T. J., \& MacDougall, M. (1996). Students' responses and approaches to case-based instruction: The role of reflective selfregulation. American Educational Research Journal, 33(3), 719-752.

Eubanks, L. P., Middlecamp, C. H., Pienta, N. J., Heltzel, C. E., \& Weaver, G. C. (2006). Chemistry in context: applying chemistry to society. Boston: Mc-Graw Hill.

Field, A. (2009). Discovering Statistics using SPSS (3rd ed.). London: Sage.

Finley, F. N, Stewart, J. \& Yarroch, W. L. (1982). Teachers' Perceptions of Important and Difficult Science Content. Science Education, 66(4), 531-538.

Fouts, J. T. \& Myers, R. E. (1992). Classroom environments and middle school students' view of science. Journal of Educational Research, 85(6), 356361.

Fraenkel, J. R., \& Wallen, N. E. (2006). How to design and evaluate research in education. Mc Grawall Hill.

Freedman, M.P. (1997). Relationship among laboratory instruction, attitude toward science, and achievement in science knowledge. Journal of Research in Science Teaching, 34, 343-357. 
Gabel, C. (1999). Using case studies to teach science. Paper presented at the Annual Meeting of the National Association for Research in Science Teaching, Boston, MA.

Gallagher, J. (1993). Secondary science teachers and constructivist practice. In K. Tobin (Eds.), The Practice of Constructivism in Science Education (pp. 180-191). New Jersey, USA: Lawrence Erlbaum Associates, Inc.

Gallagher, J. M., Reid, D. K. (1981). The Learning Theory of Piaget and Inhelder. Monterey, CA: Brooks/Cole Publishing Company.

Garnett, P.J. \& Treagust, D.F. (1992a). Conceptual difficulties experienced by senior high school students of electrochemistry: Electric circuits and oxidation-reduction equations. Journal of Research in Science Teaching, 29, 121-142.

Garnett, P. J., \& Treagust, D. F. (1992b). Conceptual difficulties experienced by senior high school students of electrochemistry: Electrochemical (Galvanic) and electrolytic cells. Journal of Research in Science Teaching, 29 (10), 1079-1099.

Geban, O., Ertepinar, H., Yilmaz, G., Altin, A., \& Sahbaz, F. (1994). Bilgisayar destekli eğitimin öğrencilerin fen bilgisi başarılarına ve fen bilgisi ilgilerine etkisi. I. Ulusal Fen Bilimleri Eğitimi Sempozyumu: Bildiri Özetleri Kitabı, (pp. 1-2). Dokuz Eylül Üniversitesi, İzmir.

Gergen, K. J. (1985). The social constructionist movement in modern psychology. American Psychologist, 40(3), 127-146.

Gibson, H. L, Chase, C. (2002). Longitudinal impact of an inquiry-based science program on middle school students' attitudes toward science. Science Education,86, 693-705.

Glaserfeld, E. V. (1993). Questions and answers about radical constructivism. In K. Tobin (Eds.), The Practise of Constructivism in Science Education (pp. 23-38). New Jersey, USA: Lawrence Erlbaum Associates, Inc. 
Glynn, S., \& Koballa, T. R. (2005). The contextual teaching and learning instructional approach. In R. E. Yager (Eds.), Exemplary Science: Best Practices In Professional Development (pp. 75-84). Arlington, Va: National Science Teachers Association Press.

Glynn, S. M., \& Koballa, T. R., Jr. (2006). Motivation to learn college science. In J. J. Mintzes \& W. H. Leonard (Eds.), Handbook of college science teaching (pp. 25-32). Arlington, VA: National Science Teachers Association Press.

Glynn, S. M., Taasoobshirazi, G., \& Brickman, P. (2007). Nonscience majors learning science: A theoretical model of motivation. Journal of Research in Science Teaching, 44(8), 1088-1107.

Gredler, M. E. (1992). Learning and instruction: Theory into Practice (2 ${ }^{\text {nd }}$ ed.). New York: Macillan, Inc.

Guest, J. M. (2007). The effectiveness of using case-based instruction in an online course. Unpublished doctoral dissertation, University of South Alabama, USA.

Haidar, A., \& Abraham, M. (1991). A comparison of applied and theoretical knowledge of concept based on the particulate nature of matter. ,. Journal of Research in Science Teaching, 28(10), 919-938.

Hair, J. F., Black, W. C., Babin, B. J., \& Anderson, R. E. (2010). Multivariate Data Analysis: A Global Perspective (7th ed.). Upper Saddle River, New Jersey: Pearson.

Haladyna, T. M. (1997). Writing test items to evaluate higher order thinking. USA: Allyn \& Bacon.

Harrison, A.G. \& Treagust, D.F. (1996). Secondary students' mental models of atoms and molecules: Implications for learning chemistry. Science Education, 80(5), 509-534.

Herreid, C. F. (1994). Case studies in science: A novel method of science education. Journal of College Science Teaching, 23, 221-229. 
Herreid, C. F. (1997). What makes a good case? Journal of College Science Tecahing, 27(3), 163-165.

Herreid, C. F. (1998). Sorting patatoes for miss bonner: bringing order to case study methodology through a classification scheme. Journal of College Science Teaching, 27(4), 236-239.

Herreid, C. F. (1999). Cooking with Betty Crocker: A recipe for case writing. Journal of College Science Tecahing, 29(3), 156-158.

Herreid, C. F. (2007). Start with a story: the case study method of teaching college science. Arlington, Va.: NSTA Press.

Herreid, C. F. (2011). Case study teaching. New Directions for Teaching and Learning, 31-40. doi:10.1002/tl.466

Hidi, S., Renninger, K. A., \& Krapp, A. (2004). Interest, a motivational variable that combines affective and cognitive functioning. In D. Y. Dai \& R. J. Sternberg (Eds.), Motivation, emotion, and cognition: Integrative perspectives on intellectual functioning and development (pp.89-115).Mahwah, NJ: Lawrance Erlbaum Associates, Inc.

Hinkle, D.E., Wiersma, W., \& Jurs, S.G. (1998). Applied statistics for the behavioral sciences (4th Ed.). Boston: Houghton Mifflin Company.

Hmelo-Silver, C. E. (2004). Problem-based learning: What and how do students learn? Educational Psychology Review, 16, 235-266.

Hofstein, A., \& Kesner, M. (2006). Industrial Chemistry and School Chemistry: Making chemistry studies more relevant. International Journal of Science Education, 28(9), 1017-1039.

Honebein, P. C. (1996). Seven Goals for the Design of Constructivist Learning Environments. In B. G. Wilson (Eds), Constructivist Learning Environments, Case Studies in Instructional Design (pp. 11-24). Englewood cliffs, New Jersey: Educational Technology Publications, Inc. 
Hutchinson, J. S. (2000). Teaching introductory chemistry using concept development case studies: interactive and inductive learning. University Chemistry Education, 4(1), 3-9.

Informatics Association of Turkey (TBD) . (Mayıs, 2010). Çevreci Bilişim Belge Grubu Raporu.

JCE Staff. (2000). Silver to Black-and Back. Journal of Chemical Education, 77(3), 328.

Johnstone, A.H., (1980). Chemical education research: Facts, findings and consequences, Chemical Society Review, 9(3), 365-380.

Jonassen, D. H. (1994). Thinking Technology: Toward a Constructivist Design Model. Educational technology, 34(4), 34-37.

Jones, M. A. (1997). Use of a classroom jury trial to enhance students' perception of science as part of their lives. Journal of Chemical Education, 74(5), 537.

Kaddoura, M. (2011). Critical thinking skills of nursing students in lecturebased teaching and case-based learning. International Journal for the Scholarship of Teaching and Learning, 5(2), 1-18.

Kain, D. L. (2003). Problem-based learning for teachers, grades 6-12. Boston: Allyn and Bacon.

Kan, A., \& Akbas, A. (2006). Affective factors that influence chemistry achievement (attitude and self-efficacy) and the power of these factors to predict chemistry achievement-I. Journal of Turkish Science Education, 3(1), 76-85.

Kim, S., Phillips, W., Pinsky, L., Brock, D., Phillips, K., \& Keary, J. (2006). A conceptual framewok for developing teaching cases: a review and synthesis of the literature across disciplines. Medical Education, 867876. 
King, D. (2009). Teaching and Learning in a Context-based Chemistry Classroom. Unpublished doctoral dissertation, Queensland University of Technology, Australia.

Knight, J. D., Fulop, R., \& Marquez-Magana, L. (2008). Investigative cases and students outcomes in an upper-division cell and molecular biology laboratory course at a minority-serving institution. CBE-Life Sciences Education, 7, 382-393.

Koballa, T. R. \& Glynn, S. M. (2007). Attitudinal and motivational constructs in science learning. In S. K. Abell \& N. G. Lederman (Eds.), Handbook of Research on Science Education (pp.75-102). Mahwah, NJ: Lawrence Erlbaum.

Kose, S., Sahin, A., Ergun, A. \& Gezer, K. (2010). The effects of cooperative learning experience on eighth grade students' achievement and attitude toward science. Education, 131(1), 169-180.

Krajcik, J., \& Czerniak, C. (2007). Teaching Science in Elementary and Middle School: A Project-based Approach. New York: Erlbaum.

Kulandaisamy, S., Rethinaraj, J. P., Adaikkalam, P., Srinivasan, G. N., \& Raghavan, M. (2003). The aqueous recovery of gold from electronic scrap. JOM, 55(8), 35-38.

Kusurkar, R. A., Croiset, G., \& Ten Cate, O. T. J. (2011). Twelve tips to stimulate intrinsic motivation in students through autonomy-supportive classroom teaching derived from self-determination theory. Medical teacher, 33(12), 978-982.

Kupermintz, H. (2002). Affective and conative factors as aptitude resources in high school science achievement. Educational Assessment, 8, 123-137.

Landis, J. R. \& Koch, G. G. (1977). The measurement of observer agreement for categorical data. Biometrics, 33, 159-174.

Lantz, J. M., \& Walczak, M. M. (1997). The Elements of a chemistry case: Teaching chemistry using the case discussion method. The Chemical Educator, 1(6). 
Leonard, W. (2000). How do college students best learn science? . Journal of College Science Teaching, 29, 385-388.

Lin, H. S., Yang, T. C., Chiu, H. L. \& Chou, C. Y. (2002). Students' difficulties in learning electrochemistry. Proceedings of the National Science Council R.O.C.: Part D,12(3), 100-105.

Linnenbrink, E. A. \& Pintrich, P. R. (2002). Motivation as an enabler for academic success. School Psychology Review, 31(3), 313-327.

Loh, A. S. L., Subramaniam, R., \& Tan, K. C. D. (2014). Exploring students' understanding of electrochemical cells using an enhanced two-tier diagnostic instrument. Research in Science \& Technological Education, DOI: 10.1080/02635143.2014.916669

Lord, T. R. (1999). A Comparison Between Traditional and Constructivist Teaching in Environmental Science. The Journal of Environmental Education, 30(3), 22-27.

Mao, S. L., \& Chang, C. Y. (1998). Impacts of an inquiry teaching method on earth science students' learning outcomes and attitudes at the secondary school level. Proceedings-National Science Council Republic of China Part D Mathematics Science And Technology Education, 8, 93-101.

Mayer, R. (1999). Designing instruction for constructivist learning. In C. M. Reigeluth (Eds.), Instructional-design theories and models: Vol. 2. A new paradigm of instructional theory (pp. 141-160). Mahwah, NJ: Lawrence Erlbaum Associates.

Mayo, J. A. (2002). Case-based instruction: A technique for increasing conceptual application in introductory psychology. Journal of Constructivist Psychology, 15(1), 65-74.

Mayo, J. A. (2004). Using case-based instruction to bridge the gap between theory and practice in psychology of adjustment. Journal of Constructivist Psychology, 17, 137-146. 
McDermott, L. C. (1993). "Guest Comment: How we teach and how students learn-A mismatch?". American Journal of Physics, 61, 295-298.

MEB (2008). Açıköğretim okulları ders kitapları: Kimya 6 ders notu. 7 Kasım 2010 tarihinde http://yegitek.meb.gov.tr/aok/Aok_Kitaplar/AolKitaplar/Kimya_6/2.pdf

MEB (2010). Ortaöğretim Kimya 11 ders kitabı. İhlas Gazetecilik A.Ş. İstanbul.

Meyers, L., Gamst, G. \& Guarino, A. J. (2006). Applied Multivariate Research Design and Interpretation. Newbury Park, CA: Sage.

Michael, J. A., \& Modell, H. I. (2003). Active learning in secondary and college science classrooms: A working model for helping the learner to learn. Mahwah NJ: Erlbaum Associates.

Michaelsen, L. K. (1992). Team learning: A comprehensive approach for harnessing the power of small groups in higher education. In D. H. Wulff, \& J. D. Nyquist (Eds.), To Improve the Academy, Vol. 11 (pp. 107-122). Stillwater, OK: New Forums Press and the Professional and Organizational Development Network in Higher Education.

Moore, J. W., Stanitski, C. L., Wood, J. L., Kotz, J. C., \& Joester, M. D. (1998). The Chemical World: concepts and applications (2nd ed.). Forth Worth: Saunders College Publishing.

Morris, J. A. (2013). How does the use of case studies, as an instructional strategy, affect the perception of relevance of science in a high school conceptual science class? Unpublished doctoral dissertation, Montana State University, Bozeman, Montana.

Morrison, T. (2001). Actionable learning: A handbook for capacity building through case based learning. Tokyo: Asian Development Bank Institute. Retrieved January 29, 2013, from http://adbi.adb.org/files/2001.06.books.actionable.learning.pdf 
Movahedzadeh, F. (2011). Improving students' attitude toward science through blended learning. Science Education and Civic Engagement, 3(2), 1319.

Murphy, P. K. \& Alexander, P. A. (2000). A motivated exploration of motivation terminology. Contemporary Educational Psychology, 25(1), 3-53.

Nakhleh, M. (1992). Why some students don't learn chemistry: Chemical misconceptions. Journal of Chemical Education, 1992, 69(3), 191-196.

Nakiboglu, N., Toscali, D., \& Nisli, G. (2003). A novel silver recovery method from waste photographic films with $\mathrm{NaOH}$ stripping. Turkish Journal of Chemistry, 27(1), 127-133.

National Research Council . (1996). National science education standards: Observe, interact, change, learn. Washington, DC: National Academy Press.

Naumes, W., \& Naumes, M. J. (2006). The art \& craft of case writing. ME Sharpe.

Ng, K. T., Lay, Y. F., Areepattamannil, S., Treagust, D. F., \& Chandrasegaran, A. L. (2012). Relationship between affect and achievement in science and mathematics in Malaysia and Singapore. Research in Science \& Technological Education, 30(3), 225-237.

Nieswandt, M. (2007). Student affect and conceptual understanding in learning chemistry. Journal of Research in Science Teaching, 44(7), 908-937.

Ogude, N. A. \& Bradley, J. D. (1996). Electrode processes and aspects relating to cell emf, current, and cell components in operating electrochemical cells: Precollege and college student interpretation. Journal of Chemical Education, 73(12), 1145 -1149.

Oliver, J. S., \& Simpson, R. D. (1988). Influences of attitude toward science, achievement motivation, and science self-concept on achievement in science: A longitudinal study. Science Education, 72(2), 143-155. 
Oliver-Hoyo, M.T. \& Allen, D. (2005). Attitudinal effects of a student-centered active learning environment. Journal of Chemical Education , 82(6), 944-949.

Osborne, J., Simon, S., \& Collins, S. (2003). Attitudes towards science: a review of the literature and its implications. International Journal of Science Education, 25(9), 1049-1079.

Ozkan, M., \& Azar, A. (2005). Örnek olaya dayalı öğretim yönteminin dokuzuncu sınıf öğrencilerinin ders başarısı ve derse karşı tutumlarına olan etkisinin incelenmesi. Milli Ĕ̈itim Dergisi, 33(168).

Ozkaya, A. R., Uce, M. \& Sahin, M. (2003). Prospective Teachers' Conceptual Understanding of Electrochemistry: Galvanic and Electrolytic Cells. Univ. Chem. Educ., 7, 1-12.

Pajares, F. (1996). Self-efficacy beliefs in academic settings. Review of Educational Research, 66(4), 543-578.

Pajares, F. (2002). Self-efficacy beliefs in academic contexts: An outline. Retrieved March 27, 2008, from http://des.emory.edu./mfp/efftalk.html

Pallant, J. (2007). SPSS survival manual: A step by step guide to data analysis using SPSS for Windows. Maidenhead: Open University Press.

Papanastasiou, E., \& Zembylas, M. (2002). The relationship between science attitudes and achievement at the senior high school year in Cyprus. International Review of Education, 48(6), 469-484.

Parchmann, I., \& Luecken, M. (2010). Context-based Learning for Students and Teachers: Professional development by participating in school innovation projects. The International Seminar, Professional Reflections. York.

Pearce, R. J. (2002). Case-based structured conflict: A means for enhancing classroom learning. Journal of Management Education, 26, 732-744. 
Petty, R. E., \& Cacioppo, J. T. (1996). Attitudes and persuasion: Classic and contemporary approaches. Boulder, CO: Westview Press.

Piaget, J. (1952). The origins of intelligence in children. New York: International University Press.

Pilot, A., \& Bulte, A. M. (2006). The Use of "Contexts" as a Challenge for the Chemistry Curriculum: Its successes and the need for further development and understanding. International Journal of Science Education, 28(9), 1087-1112.

Pintrich, P.R. (2003). A motivational science perspective on the role of student motivation in learning and teaching contexts. Journal of Educational Psychology, 95, 667-686.

Pintrich, P. R., \& Schunk, D. H. (2002). Motivation in education: Theory, research, and applications (2nd ed.). Upper Saddle River, NJ: Prentice Hall.

Rahayu, S., Treagust, D. F., Chandrasegaran, A. L., Kita, M., \& Ibnu, S. (2011). Assessment of electrochemical concepts: a comparative study involving senior high-school students in Indonesia and Japan. Research in Science \& Technological Education, 29(2), 169-188.

Rannikmäe, M., Teppo, M., \& Holbrook, J. (2010). Popularity and Relevance of Science Education Literacy: Using a Context-based Approach. Science Education International, 21(2), 116-125.

Raved, L., \& Assaraf, O. B. (2011). Attitudes towards Science Learning among 10th-Grade Students: A qualitative look. International Journal of Science Education, 33(9), 1219-1243.

Richmond, G., \& Neureither, B. (1998). Making case for cases. The American Biology Teacher, 60(5), 335-340.

Roth, K. (1990). Developing meaningful conceptual understanding in science . In B. F. Jones, \& L. I. (Eds.), Dimensions of thinking and cognitive instruction (pp. 139-175). Hillsdale, NJ: Lawrence Erlbaum Associates. 
Ryan, R. M., \& Deci, E. L. (2000). Intrinsic and extrinsic motivations: Classic definitions and new directions. Contemporary Educational Psychology, 25(1), 54-67.

Rybarczyk, B. J., Bainess, A. T., McVey, M., Thompson, J., \& Wilkins, H. (2007). A case-based approach increases student learning outcomes and comprehension of cellular respiration concepts. Biochemistry and Molecular Biology Education, 35(3), 181-186.

Salta, K., \& Tzougraki, C. (2004). Attitudes toward chemistry among 11th grade students in high schools in Greece. Science Education, 88, 535547.

Sanger, M.J. \& Greenbowe, T.J. (1997a). Common student misconceptions in electrochemistry: Galvanic, electrolytic, and concentration cells. Journal of Research in Science Teaching, 34(4), 377-398.

Sanger, M.J. \& Greenbowe, T.J. (1997b). Students' misconceptions in electrochemistry: Current flow in electrolyte solutions and the salt bridge. Journal of Chemical Education, 74, 819-823.

Saral, S. (2008). The effect of case-based learning on tenth grade students' understanding of human reproductive system and their perceived motivation. Unpublished master's thesis, Middle East Technical University, Ankara.

Savery, J. R. (2006). Overview of problem-based learning: Definitions and distinctions. The InterdisciplinaryJournal of Problem-Based Learning, 1(1), 9-20.

Savery, J. R. \& Duffy, T. M. (1995). Problem-based learning: An instructional model and its constructivist framework. In B. Wilson (Ed.), Constructivist learning environments: Case studies in instructional design (pp. 135-148). Englewood Cliffs, NJ: Educational Technology Publications. 
Schroeder, C. M., Scott, T. P., Tolson, H., Huang, T.-Y., \& Lee, Y.-H. (2007). A meta-analysis of national research: Effects of teaching strategies on student achievement in science in the United States. Journal of Research in Science Teaching. 44, 1436-1460.

Shumow, L. \& Schmidt, J. A. (2013). Enhancing adolescents' motivation for science: Research-based strategies for teaching male and female students. In APA's Classroom insights from educational psychology series, (series editor, D. Meyer). Thousand Oaks, CA: Corwin Press.

Schunk, D. H. (2000). Motivation for achievement: Past, present, and future. Issues in Education, 6(1/2), 161-166.

Schwartz, A. T. (2006). Contextualized Chemistry Education: The American experience. International Journal of Science Education, 28(9), 977998.

Sendur, G. (2012). The effects of case-based learning on freshmen students' chemistry achievement. Energy Education Science and Technology Part B: Social and Educational Studies, 4(3), 1289-1302.

Shibley, I. A., Zimmaro, D. M. (2002). The influence of collaborative learning on student attitudes and performance in an introductory chemistry laboratory. J Chem Educ, 79(6):745-748

Simpson, R. D., Koballa, T. R. Jr., Oliver, J. S., \& Crawley, F. E. III (1994). Research on the affective dimension of science learning. In D. Gabel (Ed), Handbook of research on science teaching and learning (pp. 211234). New York: Macmillan.

Simpson, D., \& Oliver, S. (1990). A summary of major influences on attitude toward and achievement in science among adolescent students. Science Education, 74, 1-18.

Singh, K., Granville, M., \& Dika, S. (2002). Mathematics and Science Achievement: Effects of Motivation, Interest, and Academic Engagement. The Journal of Educational Research, 95(6), 323-332. 
Sirhan, G. (2007). Learning difficulties in chemistry: An overview. Journal of Turkish science education, 4(2), 2-20.

Skolnick, R. (2009). Case study teaching in high school biology: effects on academic achievement, problem solving skills, teamwork skills, and science attitudes. Unpublished doctoral dissertation, TUI University, Cypress, California.

Smith, R. A., \& Murphy, S. (1998). Using case studies to increase learning \& interest in biology. The American Biology Teacher, 60(4), 265-268.

Soudani, M., Sivade, A., Cros, D., \& Medimagh, M. S. (2000). Transferring knowledge from the classroom to the real world: Redox concepts. School Science Review, 82(298), 65-72.

Sudzina, M. R. (1997). Case study as a constructivist pedagogy for teaching educational psychology. Educational Psychology Review, 9, 199-218.

Sudzina, M. R. (1997). Case study as a constructivist pedagogy for teaching educational psychology. Educational Psychology Review, 9(2), 199218.

Sungur, S. (2004). The implementation of problem based learning in high school biology courses. Unpublished doctoral dissertation, Middle East Technical University, Turkey.

Sungur, S., \& Tekkaya, C. (2006). Effects of problem-based learning and traditional instruction on self-regulated learning. The Journal of Educational Research, 99(5), 307-317.

Tabachnick, B. G. \&Fidell, L. S. (2007). Using Multivariate Analysis (5 ${ }^{\text {th }}$ Ed.). Boston: Allyn and Bacon.

Tarnvik, A. (2007). Revival of the case method: a way to retain student-centred learning in a post-PBL era. Medical Teacher, 29(1), e32-36. doi:DOI: 10.1080/01421590601039968 
Thomas, M. D., O'Connor, F. W., Albert, M. L., Boutain, D., \& Brandt, P. A. (2001). Case-based teaching and learning experiences. Issues in Mental Health Nursing, 22(5), 517-531.

Thomas, M. T., O’Connor, F. W., Albert, M. L., Boutain, D., \& Brandt, P. A. (2001). Case-based teaching and learning experiences. Issues in Mental Heath Nursing, 22, 517-531.

Thompson, J. \& Soyibo, K. (2002). Effects of lecture, teacher demonstrations, discussion and practical work on 10th graders' attitudes to chemistry and understanding of electrolysis. Research in Science \& Technological Education, 20(1), 25-35.

Toprak, M., Ozkan, A., \& Alpat, Ş. (2006). The use of submarine and see-saw models in teaching of oxidation-reduction reactions. Dokuz Eylül Üniversitesi Buca Eğitim Fakültesi Dergisi, 20, 91-100.

Tuysuz, C. (2010).The Effects of Virtual Laboratory on Students' Achievement and Attitude in Chemistry. International Online Journal of Educational Sciences, 2(1), 37-53.

Vaino, K., Holbrook, J., \& Rannikmäe, M. (2012). Stimulating students' intrinsic motivation for learning chemistry through the use of contextbased learning modules. Chemistry Education Research and Practice, 13(4), 410-419.

von Glasersfeld, E. (1995). Radical Constructivism: A Way of Knowing and Learning. London: Falmer Press.

Vygotsky, L. S. (1963). Learning and mental development at school age In B. Simon \& J. Simon (Eds.), Educational psychology in the U.S.S.R. (pp. 21-34). London: Routledge \& Kegan Paul.

Vygotsky, L. S. (1978). Mind and society: The development of higher mental processes. Cambridge, MA: Harvard University Press.

Walker, C. O., Greene, B. A., \& Mansell, R. A. (2006). Identification with academics, intrinsic/extrinsic motivation, and self-efficacy as predictors 
of cognitive engagement. Learning and Individual Differences, 16(1), $1-12$.

Walker, J. P., Sompson, V., Grooms, J., Anderson, B., \& Zimmerman, C. O. (2012). Argument-driven inquiry in undergraduate chemistry labs: The impact on students' conceptual understanding, argument skills, and attitudes toward science. Journal of College Science Teaching, 41(4), 74-81.

Wassermann, S. (1994). Introduction to case method teaching: A guide to the galaxy. New York: Teachers College Press.

Wegner, T. (2007). Applied Business Statistics: Methods and Excel-Based Applications ( $2^{\text {nd }}$ Ed.). Cape Town: Juta.

West, S. G., Taylor, A. B., \& Wu, W. (2012). Model fit and model selection in structural equation modeling. In R. H. Hoyle (Eds.) Handbook of structural equation modeling (pp. 209-231). New York: Guilford Press.

Wilcox, K. J. (1999). The case method in introductory anatomy \& Physiology: using the news. The American Biology Teacher, 61(9), 668-671.

Williams, B. (2005). Case based learning - a review of the literature: is there scope for this educational paradigm in prehospital education? Emergency Medicine Journal, 22(8), 577-581. doi:doi: 10.1136/emj.2004.022707

Woolfolk, A. (2005). Educational psychology (Active learning ed., $9^{\text {th }}$ ed.). Boston: Allyn \& Bacon.

Woolnough, B.E., \& Guo, Y. (1997). Factors affecting student choice of career in science and engineering: Parallel studies in Australia, Canada, China, England, Japan and Portugal. Research in Science \& Technological Education, 15(1), 105-121.

Wong, A.F.L., Young, D.J. \& Fraser, B.J. (1997), A multilevel analysis of learning environments and student attitudes, Educational Psychology 17, 449-468. 
Wright, S. (1996). Case-based instruction: Linking theory to practice. Physical Educator, 53(4), 190-97.

Xu, X., Villafane, S. M., \& Lewis, J. E. (2013). College students' attitudes toward chemistry, conceptual knowledge and achievement: structural equation model analysis. Chemistry Education Research and Practice, 14(2), 188-200.

Yadav, A., Lundeberg, M., De-Schryver, M., Dirkin, K., Schiller, N. A., Maier, K., \& Herreid, C. H. (2007). Teaching science with case studies: A national survey of faculty perceptions of the benefits and challenges of using cases. Journal of College Science Teaching, 37(1), 34-38.

Yalcinkaya, E., Tastan-Kirik, O., Boz, Y., \& Yildiran, D. (2012). Is case-based learning an effective teaching strategy to challenge students' alternative conceptions regarding chemical kinetics? Research in Science \& Technological Education, 30(2), 151-172.

Yalcinkaya, E. (2010). Effect of case based learning on 10 th grade students' understanding of gas concepts, their attitude and motivation. Unpublished doctoral dissertation, Middle East Technical University, Ankara.

Yong, L. (2005, July). Using problem based learning in Electrical Engineering Foundation. The China Papers, 5, 67-70.

Yuruk, N. (2007). The effect of supplementing instruction with conceptual change texts on students' conceptions of electrochemical cells. Journal of Science Education and Technology, 16, 515-523.

Yuruk, N. (2000). Effectiveness of conceptual change texts oriented instruction on understanding of electrochemical cell concepts. Unpublished Master Thesis, Middle East Technical University, Ankara.

Zusho, A., Pintrich, P. R., \& Coppola, B. (2003). Skill and will: The role of motivation and cognition in the learning of college chemistry. International Journal of Science Education, 25(9), 1081-1094. 


\section{APPENDIX A}

\section{MEB İZNi}

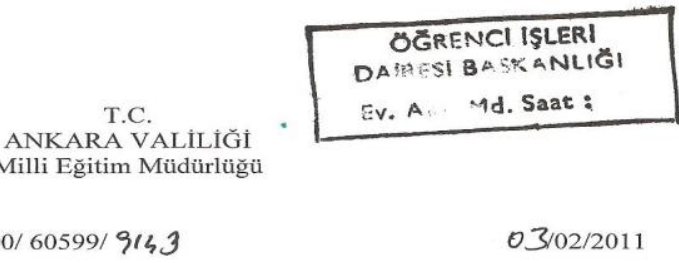

$\begin{array}{ll}\text { BÖLÜM } & \text { : İstatistik Bölümü } \\ \text { SAYI } & \text { B.08.4.MEM.0.06.22.00/60599/ } 9133 \\ \text { KONU } & \text { : Araştırma İzni }\end{array}$

$03 / 02 / 2011$

Ayșegül TARKIN

ORTA DOĞU TEKNIK ÜNIVERSITESINE

(Öğrenci İşleri Daire Başkanlığı)

Illgi : a) MEB Bağlı Okul ve Kurumlarda Yapılacak Araștırma ve Araștırma Desteğine Yönelik İzin ve Uygulama Yönergesi.

b) Üniversiteniz Öğrenci İşleri Daire Başkanlığının 12/01/2011 tarih ve 623 sayılı yazısı.

Üniversiteniz Orta Öğretim Fen Ve Matematik Alanları Eğitimi EABD doktora öğrencisi Ayșegül TARKIN'nın “Örnek Olaya Dayalı Kimya Ögretiminin ve Öğrenme Stillerinin II Sınıf Öğrencilerinin Elektrokimya Konusundaki Başarılarına, Kimyaya Karşı Tutum ve Motivasyonlarına Etkisi” konulu tezi ile ilgili çalışma yapma isteği yönerge gereği 01.03.2011 tarihinden itibaren uygulanmak üzere Müdürlüğümüzce uygun görülmüș ve araștırmanın yapılacağı İlçe Milli Eğitim Müdürlüğüne bilgi verilmiștir.

Mühürlü anketler (20 sayfadan oluşan) ekte gönderilmiş olup, uygulama yapılacak sayıda çoğaltılması ve çalışmanın bitiminde iki örneğinin ( $\mathrm{CD} /$ disket) Müdürlüğümüz İstatistik Bölümüne gönderilmesini rica ederim.

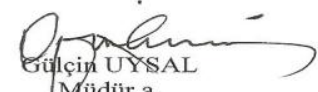

Müdür a.

Mücuir Yardımeısı

EKLER

Anket (20 sayfa)

II Milli Eğitim Müdürlügü-Beșevler

statistik Bölümü

Bilgi İçin:Nermin ÇELENK
Tel : 2237522
Fax: 2237522

istatistik06@meb.gov.tr 


\section{APPENDIX B}

\section{INSTRUCTIONAL OBJECTIVES}

1. To describe and use the quantitative expressions of Faraday's laws.

2. To establish a relationship among oxidation-reduction, electric current and material changes.

3. To idenfiy reducing and oxidizing agents in redox reactions.

4. To balance redox reactions.

5. To solve numerical problems associated with redox reactions.

6. To distinguish the concepts of electrode, half cell, galvanic cell and electrolytic cell.

7. To explain standard reduction potentials based on the standard hydrogen half cell.

8. To comprehend the change in the electrode potential by the effects of concentration and temperature.

9. To explicate the spontaneity of redox reactions on the basis of the electrode potential.

10. To explain the principles of operation of galvanic cells.

11. To give examples of common types of batteries.

12. To explain the working principles of reusable batteries (accumulator).

13. To explain electrolysis on the basis of standard electrode potentials.

14. To give examples of industrial applications of electrolysis.

15. To use the relationship among the electric current, time and amount of substance in the calculations.

16. To explain industrial corrosion.

17. To give examples of corrosion prevention techniques. 


\section{APPENDIX C}

\section{ELECTROCHEMISTRY CONCEPT TEST (PILOT)}

1.

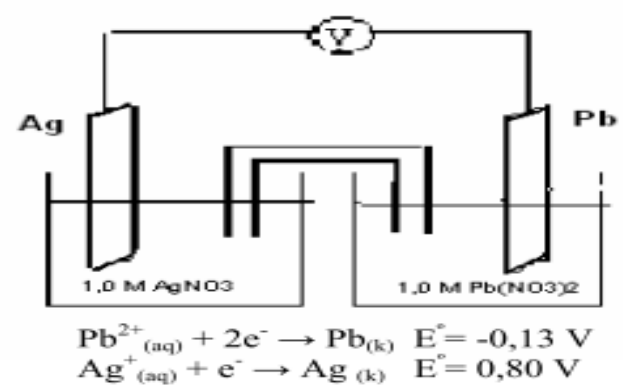

Yukarıda verilen pil diyagramı ve standart indirgenme potansiyellerine göre aşağıdaki ifadelerden hangisi doğrudur?

A) Ag elektrodu katottur çünkü Ag daha kuvvetli bir indirgendir.

B) $\mathrm{Pb}$ elektrodu katottur çünkü $\mathrm{Pb}$ elektrot pil tepkimelerinde katyon gibi elektron verir.

C) Ag elektrot standart indirgenme potansiyelinin daha yüksek olmasından dolayı anottur.

D) $\mathrm{Pb}$ elektrot standart indirgenme potansiyelinin daha düşük olmasından dolayı $\mathrm{Pb}$ indirgenir.

E) $\mathrm{Pb}$ elektrot anottur çünkü $\mathrm{Pb}$ yükseltgenmektedir.

2. $\mathrm{Zn}$ (çinko) ve $\mathrm{Cr}$ (krom) elektrotlardan oluşturulan bir galvanik pilde $\mathrm{Zn}$ elektrodun anot $\mathrm{Cr}$ elektrodun da katot olduğu bilinmektedir. Bu pil için aşağıdaki ifadelerden hangisi doğrudur?

A) $\mathrm{Zn}$ elektrodu elektron verir.

B) $\mathrm{Zn}$ elektrodunun standart indirgenme potansiyeli, Cr elektrodunun standart indirgenme potansiyelinden daha yüksektir.

C) $\mathrm{Zn}$ ve $\mathrm{Cr}$ elektrotlardan bir galvanik pil yapılmak istenirse $\mathrm{Zn}$ elektrot pilin sol tarafına yerleştirilmelidir.

D) Cr elektrotta yükseltgenme tepkimesi gerçekleşir.

E) Zn daha kuvvetli bir yükseltgendir. 
3. $\mathrm{KCIO}_{3 \text { (suda) }}+\mathrm{SO}_{2(\mathrm{~g})}+\mathrm{H}_{2} \mathrm{O}_{\text {(s) }} \longrightarrow \mathrm{KCl}_{\text {(suda) }}+\mathrm{H}_{2} \mathrm{SO}_{4 \text { (suda) }}$

Tepkimesinde indirgen ve yükseltgen elementler hangi seçenekte doğru verilmiştir?

\begin{tabular}{|c|l|}
\hline İndirgen & Yükseltgen \\
\hline A) $\mathrm{K}$ & $\mathrm{S}$ \\
\hline B) $\mathrm{S}$ & $\mathrm{Cl}$ \\
\hline C) $\mathrm{Cl}$ & $\mathrm{S}$ \\
\hline D) $\mathrm{S}$ & $\mathrm{K}$ \\
\hline E) $\mathrm{Cl}$ & $\mathrm{O}$ \\
\hline
\end{tabular}

4. Aşağıdaki tepkimelerden hangisinde altı çizilen madde indirgenmiştir?
A) $\mathrm{Zn}_{(\mathrm{k})}+2 \mathrm{HCl}_{\text {(suda) }} \longrightarrow \mathrm{ZnCl}_{2 \text { (suda) }}+\mathrm{H}_{2(\mathrm{~g})}$
B) $2 \mathrm{Na}_{(\mathrm{k})}+1 / 2 \mathrm{O}_{2(\mathrm{~g})} \longrightarrow \mathrm{Na}_{2} \mathrm{O}_{(\mathrm{k})}$
C) $\underline{\mathrm{H}}_{2(\mathrm{~g})}+\mathrm{CuO}_{(\mathrm{k})} \longrightarrow \mathrm{Cu}_{(\mathrm{k})}+\mathrm{H}_{2} \mathrm{O}(\mathrm{s})$
D) $3 \mathrm{CO}_{(\mathrm{g})}+\mathrm{Fe}_{2} \mathrm{O}_{3(\mathrm{k})} \longrightarrow 2 \mathrm{Fe}_{(\mathrm{k})}+3 \mathrm{CO}_{2(\mathrm{~g})}$
E) $\mathrm{N}_{2(\mathrm{~g})}+3 \mathrm{H}_{2(\mathrm{~g})} \longrightarrow 2 \mathrm{NH}_{3(\mathrm{~g})}$

5. Aşağıdaki tepkimelerden hangisi bir yükseltgenme -indirgenme tepkimesidir?
A) $\mathrm{MgCl}_{2(\mathrm{k})} \longrightarrow \mathrm{Mg}^{2+}{ }_{\text {(suda) }}+2 \mathrm{Cl}_{\text {(suda) }}^{-}$
B) $\mathrm{Fe}^{2+}$ (suda) $+2 \mathrm{OH}_{\text {(suda) }}^{-} \longrightarrow \mathrm{Fe}(\mathrm{OH})_{2(\mathrm{k})}$
C) $\mathrm{Mg}_{(\mathrm{k})}+\mathrm{Fe}^{2+}{ }_{\text {(suda) }} \longrightarrow \mathrm{Mg}^{2+}{ }_{\text {(suda) }}+\mathrm{Fe}_{(\mathrm{k})}$
D) $\mathrm{HCl}_{(\mathrm{s})}+\mathrm{H}_{2} \mathrm{O}_{\text {(s) }} \longrightarrow \mathrm{H}_{3} \mathrm{O}_{\text {(suda) }}^{+}+\mathrm{Cl}_{\text {(suda) }}^{-}$
E) $\mathrm{CN}_{\text {(suda) }}^{-}+\mathrm{H}_{2} \mathrm{O}_{\text {(s) }} \longrightarrow \mathrm{HCN}_{\text {(suda) }}+\mathrm{OH}_{\text {(suda) }}^{-}$

6. Bazik ortamda $\mathrm{Cr}(\mathrm{OH})_{4}^{-}$ile $\mathrm{CIO}^{-}$den $\mathrm{CrO}_{4}{ }^{2-}$ ve $\mathrm{Cl}^{-}$oluşuyor. Bu olayda yükseltgenme yarı tepkimesinin denkleşmiş denklemi aşağıdakilerden hangisidir?

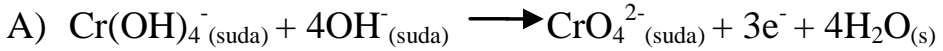
B) $\mathrm{Cr}(\mathrm{OH})_{4}^{-}$(suda) $\rightarrow \mathrm{CrO}_{4}{ }^{2-}{ }_{\text {(suda) }}+3 \mathrm{e}^{-}$
C) $\mathrm{Cr}(\mathrm{OH})_{4}^{-}$(suda) $+3 \mathrm{e}^{-} \rightarrow \mathrm{CrO}_{4}^{2-}$ (suda) $+2 \mathrm{OH}_{\text {(suda) }}^{-}$
D) $\mathrm{ClO}_{\text {(suda) }}^{-}+2 \mathrm{e}^{-} \longrightarrow \mathrm{Cl}_{\text {(suda) }}^{-}$
E) $\mathrm{ClO}_{\text {(suda) }}^{-}+2 \mathrm{e}^{-}+\mathrm{H}_{2} \mathrm{O}_{\text {(s) }} \longrightarrow \mathrm{Cl}_{\text {(suda) }}^{-}+2 \mathrm{OH}_{\text {suda) }}^{-}$

7. $\mathrm{Au}_{(\mathrm{k})}+\mathrm{NO}_{3 \text { (suda) }}^{-}+\mathrm{Cl}_{\text {(suda) }}^{-} \longrightarrow \mathrm{AuCl}_{4 \text { (suda) }}^{-}+\mathrm{NO}_{(\mathrm{g})}$ Asitli ortamda oluşan tepkime en küçük tamsayılarla denkleştirilirse Hidrojen iyonunun $\left(\mathrm{H}^{+}\right)$katsayısı kaç olur?
A) 1
B) 2
C) 3
D) 4
E) 5 
8. $\mathrm{A}, \mathrm{B}$ ve $\mathrm{C}$ metallerinin standart indirgenme potansiyelleri arasındaki ilişki $\mathrm{E}_{\mathrm{C}}{ }^{\circ}<$ $\mathrm{E}_{\mathrm{B}}{ }^{\mathrm{o}}<\mathrm{E}_{\mathrm{A}}{ }^{\circ}$ şeklindedir. Buna göre aşağıdaki ifadelerden hangisi doğrudur?

A) $\mathrm{B}$ ve $\mathrm{C}$ elektrotlardan oluşturulan bir galvanik pilde $\mathrm{B}$ elektrot elektron verir.

B) A ve $\mathrm{C}$ elektrotlardan oluşturulan bir galvanik pilde $\mathrm{C}$ elektrot katottur.

C) $\mathrm{B}$ ve $\mathrm{C}$ elektrotlarından oluşturulan bir galvanik pilde $\mathrm{B}$ elektrodun kütlesinde bir artış olur.

D) A metali hem $\mathrm{BNO}_{3}$ ile hem $\mathrm{CNO}_{3}$ ile tepkimeye girer.

E) A ve B elektrotlardan oluşturulan bir galvanik pilde A elektrot yükseltgenir.

9.

\begin{tabular}{|l|l|}
\hline \multicolumn{2}{|c|}{$\begin{array}{c}\text { Standart Elektrot Potansiyelleri } \\
\text { (Suda ve 25 }\end{array}$} \\
\hline $\begin{array}{l}\text { İndirgenme Yar } \\
\text { Reaksiyonu }\end{array}$ & $\begin{array}{l}\text { Standart Elektrot } \\
\text { Potansiyeli }(\mathrm{V})\end{array}$ \\
\hline $\mathrm{Ag}^{+}+\mathrm{e}^{-} \longrightarrow \mathrm{Ag}_{(\mathrm{k})}$ & $+0,799$ \\
\hline $\mathrm{Cu}^{2+}+2 \mathrm{e}^{-} \longrightarrow \mathrm{Cu}_{(\mathrm{k})}$ & $+0,337$ \\
\hline $\mathrm{Fe}^{3+}+3 \mathrm{e}^{-} \longrightarrow \mathrm{Fe}_{(\mathrm{k})}$ & $-0,040$ \\
\hline $\mathrm{Pb}^{2+}+2 \mathrm{e}^{-} \longrightarrow \mathrm{Pb}_{(\mathrm{k})}$ & $-0,126$ \\
\hline $\mathrm{Zn}^{2+}+2 \mathrm{e}^{-} \longrightarrow \mathrm{Zn}_{(\mathrm{k})}$ & $-0,763$ \\
\hline $\mathrm{Al}^{3+}+3 \mathrm{e}^{-} \longrightarrow \mathrm{Al}_{(\mathrm{k})}$ & $-1,662$ \\
\hline $\mathrm{Mg}^{2+}+2 \mathrm{e}^{-} \longrightarrow \mathrm{Mg}_{(\mathrm{k})}$ & $-2,863$ \\
\hline
\end{tabular}

Yukarıdaki tabloda verilen bazı elementlerin standart indirgenme potansiyelleri verilmiştir. Buna göre aşağıdaki reaksiyonlardan hangisi istemli olarak gerçekleşir?
A) $\mathrm{Cu}_{(\mathrm{k})}+\mathrm{AgNO}_{3 \text { (suda) }}$
B) $\mathrm{Pb}_{(\mathrm{k})}+\mathrm{ZnSO}_{4 \text { (suda) }}$
C) $\mathrm{Fe}_{(\mathrm{k})}+\mathrm{PbSO}_{4 \text { (suda) }}$
D) $\mathrm{Pb}(\mathrm{k})+\mathrm{Al}\left(\mathrm{NO}_{3}\right)_{3 \text { (suda) }}$
E) $\mathrm{Zn}_{(\mathrm{k})}+\mathrm{MgSO}_{4(\text { suda })}$

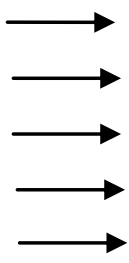

10. $\mathrm{Zn}^{2+}{ }_{\text {(suda) }}+2 \mathrm{e}^{-} \longrightarrow \mathrm{Zn}_{(\mathrm{k})} \quad \mathrm{E}^{\mathrm{O}}=-0,76 \mathrm{~V}$ $\mathrm{Fe}^{2+}{ }_{\text {(suda) }}+2 \mathrm{e}^{-} \longrightarrow \mathrm{Fe}_{(\mathrm{k})} \quad \mathrm{E}^{\mathrm{o}}=-0,44 \mathrm{~V}$

$\mathrm{Zn}$ ve Fe elektrotlardan oluşturulan galvanik pilin pil potansiyeli nedir?
A) $-0,6 \mathrm{~V}$
B) $-1,2 \mathrm{~V}$
C) $+1,2 \mathrm{~V}$
D) $-0,32 \mathrm{~V}$
E) $+0,32 \mathrm{~V}$ 
11.

$$
\begin{array}{r}
\mathrm{Fe}^{3+}{ }_{\text {(suda) }}+\mathrm{Sn}_{\text {(k) }} \longrightarrow \mathrm{Fe}^{2+}{ }_{\text {(suda) }}+\mathrm{Sn}^{2+}{ }_{\text {(suda) }} \mathrm{E}^{\mathrm{o}}=+0,91 \mathrm{~V} \\
\mathrm{Sn}^{2+}{ }_{\text {(suda) }}+2 \mathrm{e}^{-} \longrightarrow \mathrm{Sn}_{(\mathrm{k})} \quad \mathrm{E}^{\mathrm{o}}=-0,14 \mathrm{~V}
\end{array}
$$

Yukarıda verilen bilgilere göre aşağıdaki tepkimenin yarı pil potansiyeli nedir?

$$
\mathrm{Fe}^{3+} \text { (suda) }+\mathrm{e} \longrightarrow \mathrm{Fe}^{2+} \text { (suda) }
$$
A) $0,77 / 2 \mathrm{~V}$
B) $+0,77 \mathrm{~V}$
C) $-0,77 \mathrm{~V}$
D) $+1,05 \mathrm{~V}$
E) $-1,05 \mathrm{~V}$

12.

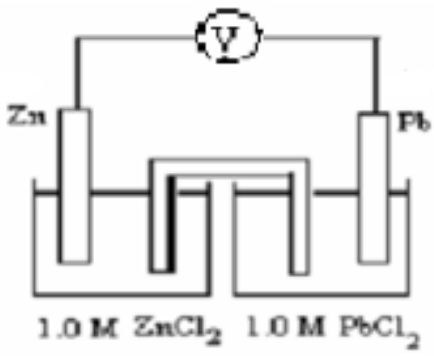

$$
\begin{array}{ll}
\mathrm{Pb}^{2+}{ }_{\text {(suda) }}+2 \mathrm{e}^{-} \longrightarrow \mathrm{Pb}_{(\mathrm{k})} & \mathrm{E}^{0}=-0,12 \mathrm{~V} \\
\mathrm{Zn}^{2+}{ }_{\text {(suda) }}+2 \mathrm{e}^{-} \longrightarrow \mathrm{Zn}_{(\mathrm{k})} & \mathrm{E}^{0}=-0,76 \mathrm{~V}
\end{array}
$$

Yukarıdaki elektrolitik pilin pil potansiyeli kaçtır?
A) $+0,22 \mathrm{~V}$
B) $-0,64 \mathrm{~V}$
C) $+0,64 \mathrm{~V}$
D) $+0,88 \mathrm{~V}$
E) $-0,88 \mathrm{~V}$

13. $\mathrm{Cu}_{(\mathrm{k})}+\mathrm{Ag}_{\text {(suda) }}^{+}(0.01 \mathrm{M}) \longrightarrow \mathrm{Cu}_{\text {(suda) }}^{+}(0.1 \mathrm{M})+\mathrm{Ag}_{(\mathrm{k})}$ tepkimesinin $25^{\circ} \mathrm{C}^{\prime}$ daki hücre potansiyeli kaçtır?

$\left(\mathrm{E}_{(\mathrm{Cu}+/ \mathrm{Cu}(\mathrm{k}))}^{\mathrm{o}}=+0.521 \mathrm{~V}, \mathrm{E}_{(\mathrm{Ag}+/ \mathrm{Ag}(\mathrm{k}))}^{\mathrm{o}}=+0,799 \mathrm{~V}\right)$
A) $0.219 \mathrm{~V}$
B) $0.278 \mathrm{~V}$
C) $0.337 \mathrm{~V}$
D) $1.320 \mathrm{~V}$
E) $1.261 \mathrm{~V}$ 


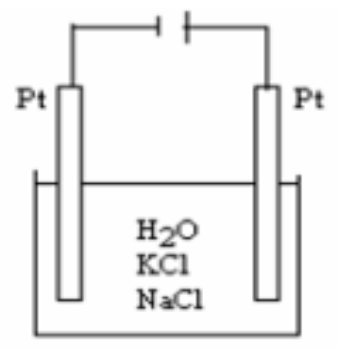

14. Sol tarafta gösterilen elektrolitik hücrede katotta meydana gelen ürün aşağıdakilerden hangisidir?

(Aşağıda bazı türlerin standart indirgenme potansiyelleri artan sırayla verilmiştir.)

$$
\begin{array}{ll}
\mathrm{K}_{\text {(suda) }}^{+}+\mathrm{e}^{-} \longrightarrow \mathrm{K}_{(\mathrm{k})} & \mathrm{E}^{0}=-2,94 \mathrm{~V} \\
\mathrm{Na}^{+}{ }_{\text {(suda) }}+\mathrm{e}^{-} \longrightarrow \mathrm{Na}_{(\mathrm{k})} & \mathrm{E}^{0}=-2,71 \mathrm{~V} \\
2 \mathrm{H}_{2} \mathrm{O}_{(\mathrm{s})}+2 \mathrm{e}^{-} \longrightarrow \mathrm{H}_{2(\mathrm{~g})}+2 \mathrm{OH}_{\text {(suda) }}^{-} & \mathrm{E}^{0}=-0,83 \mathrm{~V} \\
\mathrm{O}_{2(\mathrm{~g})}+4 \mathrm{H}^{+}{ }_{\text {(suda) }}+4 \mathrm{e}^{-} \longrightarrow 2 \mathrm{H}_{2} \mathrm{O}_{(\mathrm{s})} & \mathrm{E}^{0}=+1,23 \mathrm{~V} \\
\mathrm{Cl}_{2(\mathrm{~g})}+2 \mathrm{e}^{-} \longrightarrow 2 \mathrm{Cl}_{\text {(suda) }}^{-} & \mathrm{E}^{0}=+1,36 \mathrm{~V}
\end{array}
$$
A) $\mathrm{Pt}$
B) $\mathrm{H}_{2}$ gaz1
C) $\mathrm{Na}$
D) $\mathrm{K}$
E) Katotta oluşan tür belirlenemez.

15. Bir bakır $(\mathrm{Cu})$ metal levha $1 \mathrm{M}^{\prime}$ lık bakır nitrat $\left(\mathrm{Cu}\left(\mathrm{NO}_{3}\right)_{2}\right)$ çözeltisine batırılırken, bir gümüş $(\mathrm{Ag})$ levha ise $1 \mathrm{M}^{\prime}$ lık gümüş nitrat $\left(\mathrm{AgNO}_{3}\right)$ çözeltisine batırılmıştır. İki metal levha bir voltmetreye iletken bir telle bağlanmış ve çözeltileri birbirine bağlamak için de tuz köprüsü kullanılmıştır. Aşağıdaki standart potansiyeller bilinmektedir.

$$
\begin{array}{ll}
\mathrm{Ag}^{+}{ }_{(\mathrm{aq})}+\mathrm{e}^{-} \longrightarrow \mathrm{Ag}_{(\mathrm{k})} & \mathrm{E}^{0}=+0,80 \mathrm{~V} \\
\mathrm{Cu}^{2+}{ }_{(\mathrm{aq})}+2 \mathrm{e}^{-} \longrightarrow \mathrm{Cu}_{(\mathrm{k})} & \mathrm{E}^{0}=+0,34 \mathrm{~V}
\end{array}
$$

$\mathrm{Bu}$ pilde aşağıdakilerden hangisi gerçekleşir?

A) Elektronlar dıştaki telden geçerek bakır elektrodun bulunduğu yarı pilden gümüş elektrodun bulunduğu yarı pile doğru hareket ederler.

B) Çözeltilerdeki pozitif ve negatif iyonlar, her iki yarı pilde derişimleri eşit oluncaya kadar tuz köprüsünden geçerek hareket ederler.

C) Ag levhada yükseltgenme olurken bakır levhada indirgenme olur.

D) Sadece negatif yüklü iyonlar tuz köprüsünden hareket ederler.

E) Sadece pozitif yüklü iyonlar tuz köprüsünden hareket ederler. 
16. Galvanik bir pildeki tuz köprüsünün görevi nedir?

A) Yükseltgenme sonrası ortaya çıkan ürünlerle kompleks iyonlar oluşturmak.

B) Elektronların çözelti içinde akmasını sağlamak.

C) Her iki yarı pilde sıvıların eşit seviyede kalmasını sağlamak.

D) Pozitif ve negatif iyonların her iki yarı pile girip çıkmasını sağlamak.

E) Anot görevi görmek.

17. Yandaki elektrolitik pilde anotta ve katotta meydana gelen ürünler nelerdir?

$\left(\mathrm{Al}^{3+}, \mathrm{H}_{2} \mathrm{O}, \mathrm{Br}_{2}, \mathrm{O}_{2}\right.$ nin standart indirgenme potansiyelleri arasındaki ilişki $\mathrm{Al}^{3+}<\mathrm{H}_{2} \mathrm{O}<\mathrm{Br}_{2}<\mathrm{O}_{2}$ şeklindedir.)

\begin{tabular}{|ll|l|}
\hline \multicolumn{1}{|c|}{$\underline{\text { Anot }}$} & Katot \\
\hline A) & $\mathrm{ABr}$ & $\mathrm{Al}_{2} \mathrm{O}_{3}$ \\
\hline B) $\mathrm{Br}_{2}$ & $\mathrm{H}_{2}$ \\
\hline C) $\mathrm{Br}^{-}$ & $\mathrm{H}_{2} \mathrm{O}$ \\
\hline D) $\mathrm{Br}_{2}$ & $\mathrm{Al}$ \\
\hline E) $\mathrm{Al}$ & $\mathrm{H}_{2} \mathrm{O}$ \\
\hline
\end{tabular}

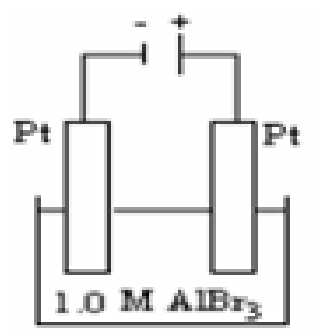

18. Suyun normal koşullardaki elektrolizi sonucunda anotta $15 \mathrm{~L}$ gaz toplanıyor. Buna göre katotta toplanan gazın cinsi ve miktarı nedir?

$\left(\mathrm{E}_{\mathrm{O} 2(\mathrm{~g}) / \mathrm{H} 2 \mathrm{O}}^{\mathrm{O}}=+1,23 \mathrm{~V} \mathrm{E}_{\mathrm{H}+/ \mathrm{H} 2(\mathrm{~g})}^{\mathrm{o}}=0,000 \mathrm{~V}\right)$
A) Oksijen, $30 \mathrm{~L}$
B) Oksijen, $75 \mathrm{~L}$
C) Hidrojen, $15 \mathrm{~L}$
D) Hidrojen, $30 \mathrm{~L}$
E) Hidrojen, $75 \mathrm{~L}$

19. $\mathrm{KAuCI}_{4}$ çözeltisi içine daldırılan bir anahtar 0,5 Amper'lik akım kullanılarak altınla kaplanmak isteniyor. $591 \mathrm{mg}$ altın kaplama yapabilmek için elektroliz işlemi kaç dakika sürmelidir? (Au: $197 \mathrm{Da})$
A) 9.65
B) 28.95
C) 96.5
D 289.5
E) 1737 
20.

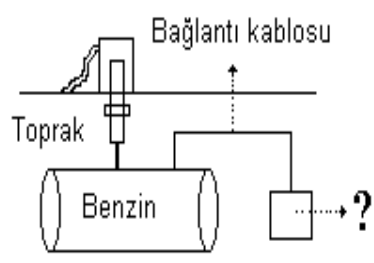

Boru hatları, gemiler, iskeleler, köprü ayakları, tanklar, kimyasal madde taşıyan kaplar, betonarme demirleri, su boruları, rafineriler ve petrol boru hatları katodik korumayla korozyondan korunabilir. Yandaki resimde

demirden yapılmış yer altındaki benzin tankını korozyondan korumak amacıyla ? işareti ile gösterilen yere aşağıdaki metallerden hangisi konulmaz?

$\left(\mathrm{E}_{\mathrm{Fe} 3+/ \mathrm{Fe}(\mathrm{k})}^{\mathrm{o}}=-0,040 \mathrm{~V}, \mathrm{E}_{\mathrm{Mg}++/ \mathrm{Mg}(\mathrm{k})}^{\mathrm{o}}=-2,863 \mathrm{~V}, \mathrm{E}_{\mathrm{Ni}++/ \mathrm{Ni}(\mathrm{k})}^{\mathrm{o}}=-0,250 \mathrm{~V}, \mathrm{E}_{\mathrm{Cu}+/ \mathrm{Cu}(\mathrm{k})}^{\mathrm{o}}=+0,337\right.$ $\left.\mathrm{V}, \mathrm{E}_{\mathrm{Al} 3+/ \mathrm{Al}(\mathrm{k})}^{\mathrm{o}}=-1,662 \mathrm{~V}, \mathrm{E}_{\mathrm{Zn} 2+/ \mathrm{Zn}(\mathrm{k})}^{\mathrm{o}}=-0,763 \mathrm{~V}\right)$
A) $\mathrm{Mg}$
B) $\mathrm{Ni}$
C) $\mathrm{Al}$
D) $\mathrm{Zn}$
E) $\mathrm{Cu}$

21.

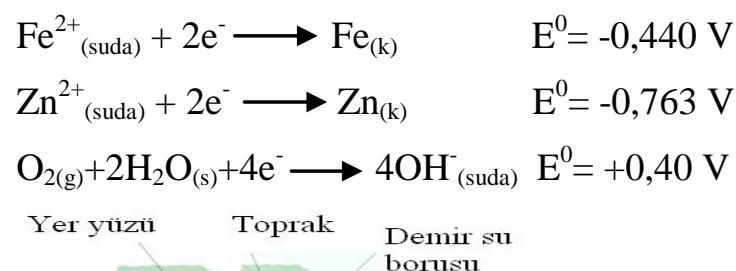

Iletken tel

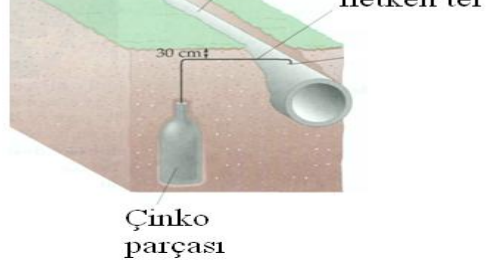

Yukarıda verilen yarı reaksiyonlar dikkate alındığında aşağıdaki ifadelerden hangisi büyük çinko parçasının yeraltından geçen demir su borularına iletken tel yardımıyla bağlanması durumunu en doğru şekilde açıklamaktadır?

A) Çinko parçası korozyona uğrar, telden akım geçer ve $\mathrm{O}_{2}$ çinko parçasının yüzeyinde indirgenir.

B) Çinko parçası korozyona uğrar, telden akım geçer ve $\mathrm{Fe}^{2+}$ demir borunun yüzeyinde indirgenir.

C) Demir boru korozyona uğrar, telden akım geçer ve $\mathrm{Zn}^{2+}$ çinko parçasının üzerinde indirgenir.

D) Demir boru korozyona uğrar, telden akım geçmez ve $\mathrm{O}_{2}$ demir borunun yüzeyinde indirgenir.

E) $\mathrm{Ne}$ demir boru ne de çinko metali yükseltgenir ama $\mathrm{O}_{2}$ indirgenir. 
22. Utku'nun bir kimya laboratuarı dersinde aşağıda verilen maddelerden en büyük pozitif pil potansiyeli üreten bir pil düzeneği kurması gerekmektedir. Sizce Utku aşağıdaki şekilde numaralandırılan yerlerde hangi maddeleri kullanırsa en büyük pil potansiyelini elde eder?

$\left(\mathrm{E}_{\mathrm{Al} 3+/ \mathrm{Al}(\mathrm{k})}^{\mathrm{o}}=-1,662 \mathrm{~V}, \mathrm{E}_{\mathrm{Cu} 2+/ \mathrm{Cu}(\mathrm{k})}^{\mathrm{o}}=+0,337 \mathrm{~V}, \mathrm{E}_{\mathrm{Fe} 2+/ \mathrm{Fe}(\mathrm{k})}^{\mathrm{o}}=-0,440 \mathrm{~V}, \mathrm{E}_{\mathrm{Ag}+/ \mathrm{Ag}(\mathrm{k})}^{\mathrm{o}}\right.$ $=+0,799 \mathrm{~V}$ )

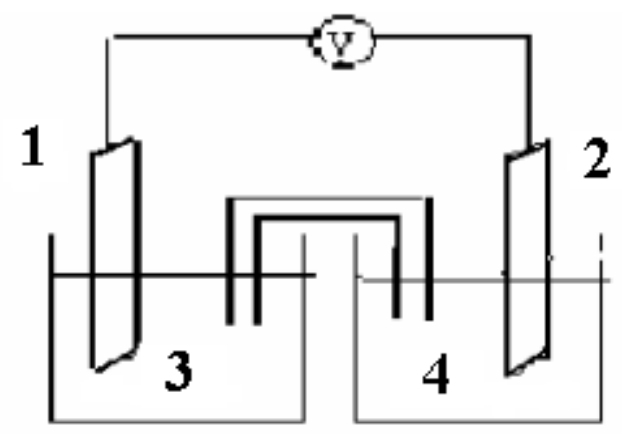

Utku'nun sahip olduğu malzemeler:
Al çubuk
$0.1 \mathrm{M} \mathrm{Al}\left(\mathrm{NO}_{3}\right)_{3}$ çözeltisi
$\mathrm{Cu}$ çubuk
$0.1 \mathrm{M} \mathrm{Cu}\left(\mathrm{NO}_{3}\right)_{2}$ çözeltisi
Fe çubuk
$0.1 \mathrm{M} \mathrm{Fe}\left(\mathrm{NO}_{3}\right)_{2}$ çözeltisi
Ag çubuk
$0.1 \mathrm{M} \mathrm{AgNO}_{3}$ çözeltisi

\begin{tabular}{|l|l|l|l|l|}
\hline & $\mathbf{1}$ & $\mathbf{2}$ & $\mathbf{3}$ & $\mathbf{4}$ \\
\hline $\mathrm{A})$ & $\mathrm{Al}$ & $\mathrm{Fe}$ & $\mathrm{Al}\left(\mathrm{NO}_{3}\right)_{3}$ & $\mathrm{Fe}\left(\mathrm{NO}_{3}\right)_{2}$ \\
\hline B) & $\mathrm{Al}$ & $\mathrm{Cu}$ & $\mathrm{Al}\left(\mathrm{NO}_{3}\right)_{3}$ & $\mathrm{Cu}\left(\mathrm{NO}_{3}\right)_{2}$ \\
\hline C) & $\mathrm{Fe}$ & $\mathrm{Cu}$ & $\mathrm{Fe}\left(\mathrm{NO}_{3}\right)_{2}$ & $\mathrm{Cu}\left(\mathrm{NO}_{3}\right)_{2}$ \\
\hline D) & $\mathrm{Ag}$ & $\mathrm{Al}$ & $\mathrm{AgNO}$ & $\mathrm{Al}\left(\mathrm{NO}_{3}\right)_{3}$ \\
\hline E) & $\mathrm{Cu}$ & $\mathrm{Ag}$ & $\mathrm{Cu}\left(\mathrm{NO}_{3}\right)_{2}$ & $\mathrm{AgNO}$ \\
\hline
\end{tabular}


23. Kararmış gümüş eşyalar $\left(\mathrm{Ag}_{2} \mathrm{~S}_{(\mathrm{k})}\right)$ içinde kabartma tozundan $\left(\mathrm{NaHCO}_{3}\right)$ hazırlanmış çözelti bulunan alüminyum bir kaba konulduğunda tekrar parlak hale $\left(\mathrm{Ag}_{(\mathrm{k})}\right)$ getirilmektedir. Bu işlem sırasında aşağıdaki reaksiyon gerçekleşmektedir.

$3 \mathrm{Ag}_{2} \mathrm{~S}_{(\mathrm{k})}+2 \mathrm{Al}_{(\mathrm{k})}+3 \mathrm{H}_{2} \mathrm{O}_{(\mathrm{s})} \longrightarrow 6 \mathrm{Ag}_{(\mathrm{k})}+\mathrm{Al}_{2} \mathrm{O}_{3(\mathrm{k})}+3 \mathrm{H}_{2} \mathrm{~S}_{(\text {suda })}$

Buna göre gümüşün parlatılması işlemi ile ilgili aşağıdaki ifadelerden hangisi doğrudur?
A) Kararmış gümüş parçası anot görevi görür.
B) Parlatma sürecinde çözeltideki Al3+ iyonları metalik Al haline indirgenir.
C) Kabartma tozu çözeltisi elektrolit görevi görür.
D) Parlatma işlemi sırasında sülfür yükseltgenir.
E) Al yükseltgendir.

24. Ege katıldığı bir bilim şenliği etkinliği sırasında gördüğü "Gümüş Ağacı" adlı bir projeyi çok beğenmiştir. Bu proje de bakır tel kullanılarak hazırlanan ağaç gümüş nitrat çözeltisine daldırılmış ve aşağıdaki görüntü elde edilmiştir.

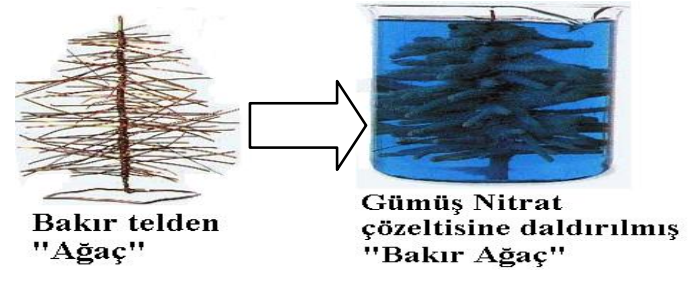

Aşağıdaki ifadelerden hangisi bu durumu açıklamaktadır?

$\left(\mathrm{E}_{\mathrm{Cu}+/ \mathrm{Cu}(\mathrm{k})}^{\mathrm{o}}=+0,337 \mathrm{~V}, \mathrm{E}_{\mathrm{Ag}+/ \mathrm{Ag}(\mathrm{k})}^{\mathrm{o}}=+0,799 \mathrm{~V}\right)$

A) Bakır indirgenerek çözeltiye geçerken çözeltideki gümüş iyonları bakır tel üzerinde metalik haline yükseltgenmiştir.

B) Bakır yükseltgenerek çözeltiye geçerken çözeltideki gümüş iyonları bakır tel üzerinde metalik $\mathrm{Ag}$ haline indirgenmiştir.

C) Bakır katot görevi görerek gümüşü yükseltgemiştir.

D) Bakır, gümüş ile kompleks oluşturmuştur.

E) Gerçekleşen tepkime $\mathrm{Cu}(\mathrm{k})+\mathrm{AgNO} 3 \longrightarrow \mathrm{Cu}(\mathrm{NO} 3)($ suda $)+\mathrm{Ag}(\mathrm{k})+2 \mathrm{e}-$ şeklindedir. 
25. Otomobil üreticileri daha çevreci araçlar üretmek için yakıt olarak $\mathrm{H}_{2}$ gazı kullanan motorlar geliştirmektedirler. $\mathrm{H}_{2}$ gazının elde edilme yöntemlerinden biri de suyun elektrolizidir. $\mathrm{H}_{2}$ eldesi için suyun elektrolizi ile ilgili olarak aşağıdakilerden hangisi yanlıştır? (Suyun elektrolizi $\mathrm{H}_{2} \mathrm{SO}_{4}$ içerisinde

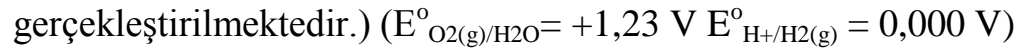

A) Suyun elektrolizi sonucu açığa çıkan hidrojen gazı oksijen gazının iki katıdır.

B) Anoda bir kibrit yaklaştırılırsa kibritin daha parlak yandığı gözlenir.

C) $2 \mathrm{H}_{2} \mathrm{O}_{(\mathrm{s})} \longrightarrow 2 \mathrm{H}_{2(\mathrm{~g})}+\mathrm{O}_{2(\mathrm{~g})}$ tepkimesinin standart hücre potansiyeli -1,23 Volttur.

D) Suyun elektrolizinde devreden $1 \mathrm{~F}$ (Faraday) elektrik yükü geçerse $1 \mathrm{~mol}_{2}$ gazı oluşur.

E) Katotta oksijen gazı oluşur.

26. Sibel'in kimya laboratuarı dersinde bakır bir malzemeyi gümüş ile kaplamak için bir deney düzeneği kurması gerekmektedir. Sizce Sibel pilin hangi kutbuna hangi maddeyi bağlarsa ve hangi çözeltiyi kullanırsa doğru bir düzenek kurmuş olur?

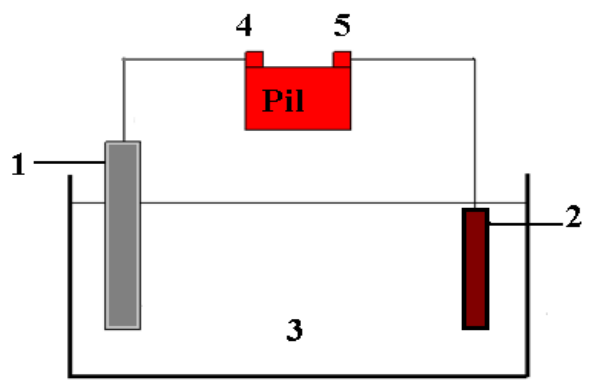

Sibel'in sahip olduğu malzemeler:

Kaplanacak olan bakır malzeme $(\mathrm{Cu})$

Gümüş çubuk (Ag)

$0.1 \mathrm{M} \mathrm{Cu}\left(\mathrm{NO}_{3}\right)_{2}$ çözeltisi

$0.1 \mathrm{M} \mathrm{AgNO}_{3}$ çözeltisi

\begin{tabular}{|l|l|l|l|l|l|}
\hline & $\mathbf{1}$ & $\mathbf{2}$ & $\mathbf{3}$ & $\mathbf{4}$ & $\mathbf{5}$ \\
\hline $\mathrm{A})$ & $\mathrm{Ag}$ & $\mathrm{Cu}$ & $\mathrm{Cu}\left(\mathrm{NO}_{3}\right)_{2}$ & - & + \\
\hline B) & $\mathrm{Ag}$ & $\mathrm{Cu}$ & $\mathrm{Cu}\left(\mathrm{NO}_{3}\right)_{2}$ & + & - \\
\hline C) & $\mathrm{Ag}$ & $\mathrm{Cu}$ & $\mathrm{AgNO}_{3}$ & + & - \\
\hline D) & $\mathrm{Cu}$ & $\mathrm{Ag}$ & $\mathrm{AgNO}_{3}$ & + & - \\
\hline E) & $\mathrm{Cu}$ & $\mathrm{Cu}$ & $\mathrm{AgNO}_{3}$ & - & + \\
\hline
\end{tabular}


27.

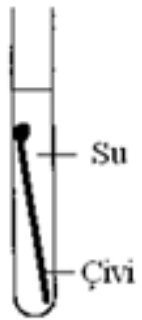

I

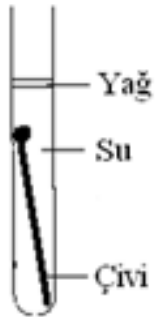

II

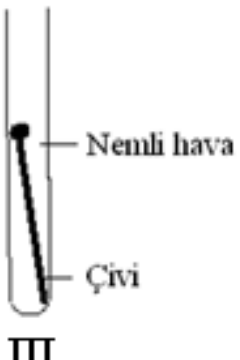

III

Yukarıda numaralandırılmış halde gösterilen deneylerden hangilerinde bir süre sonra demir çivinin paslandığı gözlemlenir?
A) Yalnız I
B) Yalnız II
C) Yalnız III
D) I ve III
E) I, II ve III

28.

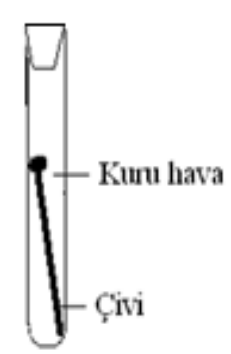

Yandaki şekilde görüldüğü gibi demir bir çivi kuru hava içeren bir deney tüpü içine yerleştirilerek tüpün ağzı sıkıca kapatılmıştır. Buna göre aşağıdaki ifadelerden hangisi doğrudur?
A) Çivide hiçbir değişiklik gözlemlenmez.
B) Bir süre sonra çivide paslanma gözlemlenir.
C) Havadaki oksijen indirgenirken demir yükseltgenir.
D) Hava ile demir arasında redoks tepkimesi gerçekleşir.
E) Demir çivi oksitlenerek korozyona uğrar. 
29.

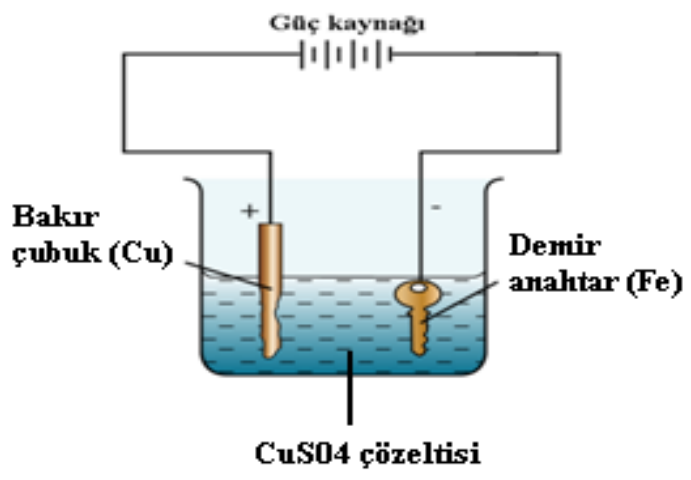

Yukarıdaki şekilde gösterilen olay ile ilgili aşağıdaki ifadelerden hangisi yanlıştır?
A) Elektronun hareketi güç kaynağı-demir anahtar- çözelti- bakır çubuk- güç kaynağ1 şeklindedir.
B) Anahtardaki Fe atomları güç kaynağından gelen elektronları alarak indirgenir.
C) Bakır çubuktaki $\mathrm{Cu}$ atomları elektron vererek $\mathrm{Cu}^{2+}$ halinde çözeltiye geçer.
D) Zamanla demir anahtar üzerinde bakır atomları birikir.
E) Bakır çubuk anot görevi görür. 


\section{APPENDIX D}

\section{ELECTROCHEMISTRY CONCEPT TEST (FINAL FORM)}

1.

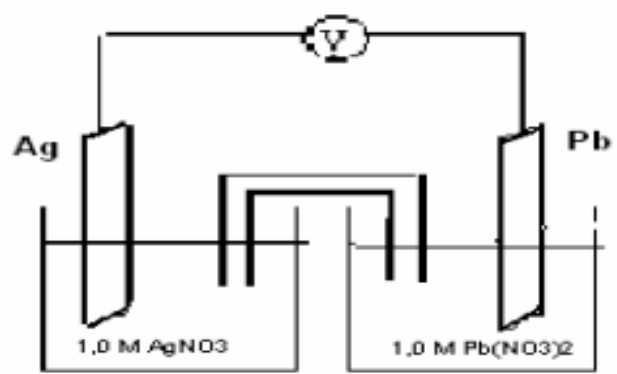

$\mathrm{Pb}^{2+}{ }_{(\mathrm{aq})}+2 \mathrm{e}^{-} \rightarrow \mathrm{Pb}_{(\mathrm{k})} \quad \mathrm{E}^{\circ}=-0,13 \mathrm{~V}$

$\mathrm{Ag}_{(\mathrm{aq})}^{+}+\mathrm{e}^{-} \rightarrow \mathrm{Ag}_{(\mathrm{k})} \quad \mathrm{E}^{\circ}=0,80 \mathrm{~V}$

Yukarıda verilen pil diyagramı ve standart indirgenme potansiyellerine göre aşağıdaki ifadelerden hangisi doğrudur?

A) Ag elektrodu katottur çünkü Ag daha kuvvetli bir indirgendir.

B) $\mathrm{Pb}$ elektrodu katottur çünkü $\mathrm{Pb}$ elektrot pil tepkimelerinde katyon gibi elektron verir.

C) Ag elektrot standart indirgenme potansiyelinin daha yüksek olmasından dolay1 anottur.

D) $\mathrm{Pb}$ elektrot standart indirgenme potansiyelinin daha düşük olmasından dolayı $\mathrm{Pb}$ indirgenir.

E) $\mathrm{Pb}$ elektrot anottur çünkü $\mathrm{Pb}$ yükseltgenmektedir.

2. Aşağıdaki tepkimelerden hangisinde altı çizilen madde indirgenmiştir?
A) $\underline{\mathrm{Zn}}_{(\mathrm{k})}+2 \mathrm{HCl}_{\text {(suda) }} \longrightarrow \mathrm{ZnCl}_{2 \text { (suda) }}+\mathrm{H}_{2 \text { (g) }}$
B) $2 \mathrm{Na}_{(\mathrm{k})}+1 / 2 \mathrm{O}_{2(\mathrm{~g})} \longrightarrow \mathrm{Na}_{2} \mathrm{O}_{(\mathrm{k})}$
C) $\underline{\mathrm{H}}_{2(\mathrm{~g})}+\mathrm{CuO}_{(\mathrm{k})} \longrightarrow \mathrm{Cu}_{(\mathrm{k})}+\mathrm{H}_{2} \mathrm{O}(\mathrm{s})$
D) $3 \mathrm{CO}_{(\mathrm{g})}+\mathrm{Fe}_{2} \mathrm{O}_{3(\mathrm{k})} \longrightarrow 2 \mathrm{Fe}_{(\mathrm{k})}+3 \mathrm{CO}_{2(\mathrm{~g})}$
E) $\underline{\mathrm{N}}_{2(\mathrm{~g})}+3 \mathrm{H}_{2(\mathrm{~g})} \longrightarrow 2 \mathrm{NH}_{3(\mathrm{~g})}$ 
3. $\mathrm{Zn}$ (çinko) ve $\mathrm{Cr}$ (krom) elektrotlardan oluşturulan bir galvanik pilde $\mathrm{Zn}$ elektrodun anot $\mathrm{Cr}$ elektrodun da katot olduğu bilinmektedir. Bu pil için aşağıdaki ifadelerden hangisi doğrudur?

A) $\mathrm{Zn}$ elektrodu elektron verir.

B) Zn elektrodunun standart indirgenme potansiyeli, Cr elektrodunun standart indirgenme potansiyelinden daha yüksektir.

C) Zn ve Cr elektrotlardan bir galvanik pil yapılmak istenirse $\mathrm{Zn}$ elektrot pilin sol tarafina yerleştirilmelidir.

D) Cr elektrotta yükseltgenme tepkimesi gerçekleşir.

E) Zn daha kuvvetli bir yükseltgendir.

4. $\mathrm{KCIO}_{3 \text { (suda) }}+\mathrm{SO}_{2(\mathrm{~g})}+\mathrm{H}_{2} \mathrm{O}_{\text {(s) }} \longrightarrow \mathrm{KCl}_{\text {(suda) }}+\mathrm{H}_{2} \mathrm{SO}_{4 \text { (suda) }}$

Tepkimesinde indirgen ve yükseltgen elementler hangi seçenekte doğru verilmiştir?

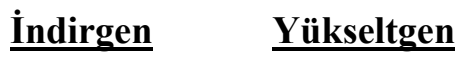

$\begin{array}{ll}\text { A) } \mathrm{K} & \mathrm{S} \\ \text { B) } \mathrm{S} & \mathrm{Cl} \\ \text { C) } \mathrm{Cl} & \mathrm{S} \\ \text { D) } \mathrm{S} & \mathrm{K} \\ \text { E) } \mathrm{Cl} & \mathrm{O}\end{array}$

5. Aşağıdaki tepkimelerden hangisi bir yükseltgenme -indirgenme tepkimesidir?

A) $\mathrm{MgCl}_{2(\mathrm{k})} \longrightarrow \mathrm{Mg}^{2+}{ }_{\text {(suda) }}+2 \mathrm{Cl}_{\text {(suda) }}^{-}$

B) $\mathrm{Fe}^{2+}$ (suda) $+2 \mathrm{OH}_{\text {(suda) }}^{-} \longrightarrow \mathrm{Fe}(\mathrm{OH})_{2(\mathrm{k})}$

C) $\mathrm{Mg}_{(\mathrm{k})}+\mathrm{Fe}^{2+}{ }_{\text {(suda) }} \longrightarrow \mathrm{Mg}^{2+}{ }_{\text {(suda) }}+\mathrm{Fe}_{(\mathrm{k})}$

D) $\mathrm{HCl}_{(\mathrm{s})}+\mathrm{H}_{2} \mathrm{O}_{(\mathrm{s})} \longrightarrow \mathrm{H}_{3} \mathrm{O}_{\text {(suda) }}^{+}+\mathrm{Cl}_{\text {(suda) }}^{-}$

E) $\mathrm{CN}_{\text {(suda) }}^{-}+\mathrm{H}_{2} \mathrm{O}_{\text {(s) }} \longrightarrow \mathrm{HCN}_{\text {(suda) }}+\mathrm{OH}_{\text {(suda) }}^{-}$

6. Bazik ortamda $\mathrm{Cr}(\mathrm{OH})_{4}^{-}$ile $\mathrm{CIO}^{-}$den $\mathrm{CrO}_{4}{ }^{2-}$ ve $\mathrm{Cl}^{-}$oluşuyor. Buna göre denkleştirilmiş yükseltgenme yarı tepkimesi aşağıdakilerden hangisidir?

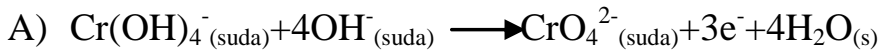
B) $\mathrm{Cr}(\mathrm{OH})_{4}^{-}$(suda) $\longrightarrow \mathrm{CrO}_{4}{ }^{2-}{ }_{\text {(suda) }}+3 \mathrm{e}^{-}$
C) $\mathrm{Cr}(\mathrm{OH})_{4}^{-}$(suda) $+3 \mathrm{e}^{-} \longrightarrow \mathrm{CrO}_{4}{ }^{2-}$ (suda) $+2 \mathrm{OH}_{\text {(suda) }}^{-}$
D) $\mathrm{ClO}_{\text {(suda) }}^{-}+2 \mathrm{e}^{-} \longrightarrow \mathrm{Cl}_{\text {(suda) }}^{-}$
E) $\mathrm{ClO}_{\text {(suda) }}^{-}+2 \mathrm{e}^{-}+\mathrm{H}_{2} \mathrm{O}_{(\mathrm{s})} \longrightarrow \mathrm{Cl}_{\text {(suda) }}^{-}+2 \mathrm{OH}_{\text {suda) }}^{-}$ 
7. $\mathrm{Au}_{(\mathrm{k})}+\mathrm{NO}_{3}^{-}{ }_{\text {(suda) }}^{-}+\mathrm{Cl}_{\text {(suda) }}^{-} \longrightarrow \mathrm{AuCl}_{4}^{-}{ }_{\text {(suda) }}+\mathrm{NO}_{\text {(g) }}$ Asitli ortamda oluşan tepkime en küçük tamsayılarla denkleştirilirse Hidrojen iyonunun $\left(\mathrm{H}^{+}\right)$katsayısı kaç olur?
A) 1
B) 2
C) 3
D) 4
E) 5

8. $\mathrm{A}, \mathrm{B}$ ve $\mathrm{C}$ metallerinin standart indirgenme potansiyelleri arasındaki ilişki $\mathrm{E}_{\mathrm{C}}{ }^{\circ}<\mathrm{E}_{\mathrm{B}}{ }^{\mathrm{o}}<\mathrm{E}_{\mathrm{A}}{ }^{\mathrm{o}}$ şeklindedir. Buna göre aşağıdaki ifadelerden hangisi doğrudur?

A) $\mathrm{B}$ ve $\mathrm{C}$ elektrotlardan oluşturulan bir galvanik pilde $\mathrm{B}$ elektrot elektron verir.

B) $\mathrm{A}$ ve $\mathrm{C}$ elektrotlardan oluşturulan bir galvanik pilde $\mathrm{C}$ elektrot katottur.

C) $\mathrm{B}$ ve $\mathrm{C}$ elektrotlarından oluşturulan bir galvanik pilde $\mathrm{B}$ elektrodun kütlesinde bir artış olur.

D) A metali hem $\mathrm{BNO}_{3}$ ile hem $\mathrm{CNO}_{3}$ ile tepkimeye girer.

E) A ve B elektrotlardan oluşturulan bir galvanik pilde A elektrot yükseltgenir.

9.

\begin{tabular}{|l|l|}
\hline \multicolumn{2}{|c|}{$\begin{array}{c}\text { Standart Elektrot Potansiyelleri } \\
\text { (Suda ve 25'C) }\end{array}$} \\
\hline İndirgenme Yar1 Reaksiyonu & $\begin{array}{l}\text { Standart Elektrot } \\
\text { Potansiyeli }(\mathrm{V})\end{array}$ \\
\hline $\mathrm{Ag}^{+}+\mathrm{e}^{-} \longrightarrow \mathrm{Ag}_{(\mathrm{k})}$ & $+0,799$ \\
\hline $\mathrm{Cu}^{2+}+2 \mathrm{e}^{-} \longrightarrow \mathrm{Cu}_{(\mathrm{k})}$ & $+0,337$ \\
\hline $\mathrm{Fe}^{3+}+3 \mathrm{e}^{-} \longrightarrow \mathrm{Fe}_{(\mathrm{k})}$ & $-0,040$ \\
\hline $\mathrm{Pb}^{2+}+2 \mathrm{e}^{-} \longrightarrow \mathrm{Pb}_{(\mathrm{k})}$ & $-0,126$ \\
\hline $\mathrm{Zn}^{2+}+2 \mathrm{e}^{-} \longrightarrow \mathrm{Zn}_{(\mathrm{k})}$ & $-0,763$ \\
\hline $\mathrm{Al}^{3+}+3 \mathrm{e}^{-} \longrightarrow \mathrm{Al}_{(\mathrm{k})}$ & $-1,662$ \\
\hline $\mathrm{Mg}^{2+}+2 \mathrm{e}^{-} \longrightarrow \mathrm{Mg}_{(\mathrm{k})}$ & $-2,863$ \\
\hline
\end{tabular}

Yukarıdaki tabloda verilen bazı elementlerin standart indirgenme potansiyelleri verilmiştir. Buna göre aşağıdaki reaksiyonlardan hangisi istemli olarak gerçekleşir?
A) $\mathrm{Cu}_{(\mathrm{k})}+\mathrm{AgNO}_{3 \text { (suda) }}$
B) $\mathrm{Pb}_{(\mathrm{k})}+\mathrm{ZnSO}_{4 \text { (suda) }}$
C) $\mathrm{Fe}_{(\mathrm{k})}+\mathrm{PbSO}_{4 \text { (suda) }}$
D) $\mathrm{Pb}(\mathrm{k})+\mathrm{Al}\left(\mathrm{NO}_{3}\right)_{3 \text { (suda) }}$
E) $\mathrm{Zn}_{(\mathrm{k})}+\mathrm{MgSO}_{4(\text { suda })}$

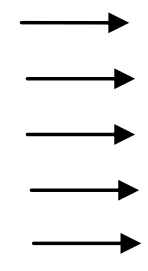


10.

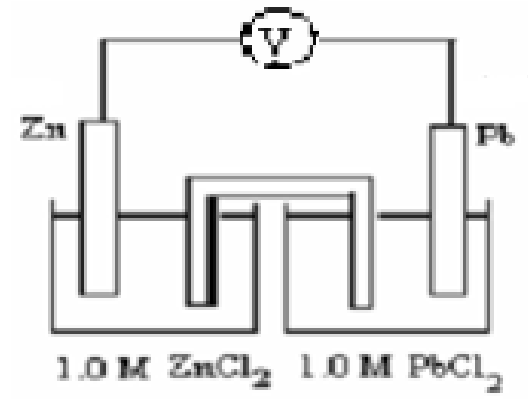

$\mathrm{Pb}^{2+}$ (suda) $+2 \mathrm{e}^{-} \longrightarrow \mathrm{Pb}_{(\mathrm{k})} \quad \mathrm{E}^{0}=-0,12 \mathrm{~V}$

$\mathrm{Zn}^{2+}$ (suda) $+2 \mathrm{e}^{-} \longrightarrow \mathrm{Zn}_{(\mathrm{k})} \quad \mathrm{E}^{0}=-0,76 \mathrm{~V}$

Yukarıdaki galvanik pilin pil potansiyeli kaçtır?
A) $+0,22 \mathrm{~V}$
B) $-0,64 \mathrm{~V}$
C) $+0,64 \mathrm{~V}$
D) $+0,88 \mathrm{~V}$
E) $-0,88 \mathrm{~V}$

11.

$$
\begin{array}{ll}
\mathrm{Fe}^{3+}{ }_{\text {(suda) }}+\mathrm{Sn}_{(\mathrm{k})} \longrightarrow \mathrm{Fe}^{2+}{ }_{\text {(suda) }}+\mathrm{Sn}^{2+}{ }_{\text {(suda) }} & \mathrm{E}^{\mathrm{o}}=+0,91 \mathrm{~V} \\
\mathrm{Sn}^{2+}{ }_{\text {(suda) }}+2 \mathrm{e}^{-} \longrightarrow \mathrm{Sn}_{(\mathrm{k})} & \mathrm{E}^{\mathrm{o}}=-0,14 \mathrm{~V}
\end{array}
$$

Yukarıda verilen bilgilere göre aşağıdaki tepkimenin yarı pil potansiyeli nedir?

$$
\mathrm{Fe}^{3+}{ }_{\text {(suda) }}+\mathrm{e}^{-} \longrightarrow \mathrm{Fe}^{2+} \text { (suda) }
$$
A) $0,77 / 2 \mathrm{~V}$
B) $+0,77 \mathrm{~V}$
C) $-0,77 \mathrm{~V}$
D) $+1,05 \mathrm{~V}$
E) $-1,05 \mathrm{~V}$

12.

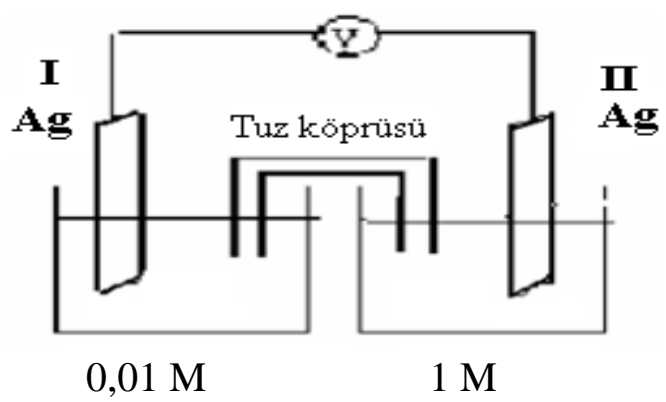

Yukarıdaki şekilde görülen pil için aşağıdaki ifadelerden hangisi yanlıştır?
A) Elektronlar I.elektrottan II. Elektrota doğru akar.
B) I. elektrodun bulunduğu kapta $\mathrm{Ag}^{+}$iyonları artar.
C) Derişimler eşit olduğunda pilin gerilimi sıfır olur.
D) I. Elektrotun kütlesi azalır.
E) II. Elektrotta yükseltgenme olur. 
13. Galvanik bir pildeki tuz köprüsünün görevi nedir?

A) Yükseltgenme sonrası ortaya çıkan ürünlerle kompleks iyonlar oluşturmak.

B) Elektronların çözelti içinde akmasını sağlamak.

C) Her iki yarı pilde sıvıların eşit seviyede kalmasını sağlamak.

D) Pozitif ve negatif iyonların her iki yarı pile girip çıkmasını sağlamak.

E) Anot görevi görmek.

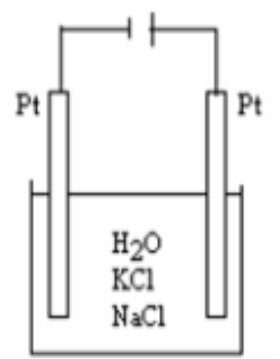

14. Sol tarafta gösterilen elektroliz işleminde katotta meydana gelen ilk ürün aşağıdakilerden hangisidir?

(Aşağıda bazı türlerin standart indirgenme potansiyelleri artan sırayla verilmiştir.)

$$
\begin{aligned}
& \mathrm{K}^{+}{ }_{\text {(suda) }}+\mathrm{e}^{-} \longrightarrow \mathrm{K}_{(\mathrm{k})} \\
& \mathrm{Na}^{+} \text {(suda) }+\mathrm{e}^{-} \longrightarrow \mathrm{Na}_{(\mathrm{k})} \\
& 2 \mathrm{H}_{2} \mathrm{O}_{(\mathrm{s})}+2 \mathrm{e}^{-} \longrightarrow \mathrm{H}_{2(\mathrm{~g})}+2 \mathrm{OH}^{-} \text {(suda) } \\
& \mathrm{O}_{2(\mathrm{~g})}+4 \mathrm{H}^{+}{ }_{\text {(suda) }}+4 \mathrm{e}^{-} \longrightarrow 2 \mathrm{H}_{2} \mathrm{O}_{(\mathrm{s})} \\
& \mathrm{Cl}_{2(\mathrm{~g})}+2 \mathrm{e}^{-} \longrightarrow 2 \mathrm{Cl}^{-} \text {(suda) }
\end{aligned}
$$

$$
\begin{aligned}
& E^{0}=-2,94 V \\
& E^{0}=-2,71 V \\
& E^{0}=-0,83 V \\
& E^{0}=+1,23 V \\
& E^{0}=+1,36 V
\end{aligned}
$$

\begin{tabular}{|c|c|c|}
\hline & $\underline{\text { Anot }}$ & $\underline{\text { Katot }}$ \\
\hline A) & $\overline{\mathrm{HBr}}$ & $\mathrm{Al}_{2} \mathrm{O}_{3}$ \\
\hline B) & $\mathrm{Br}_{2}$ & $\mathrm{H}_{2}$ \\
\hline C) & $\mathrm{Br}^{-}$ & $\mathrm{H}_{2} \mathrm{O}$ \\
\hline D) & $\mathrm{Br}_{2}$ & $\mathrm{Al}$ \\
\hline E) & $\mathrm{Al}$ & $\mathrm{H}_{2} \mathrm{O}$ \\
\hline
\end{tabular}
A) $\mathrm{Pt}$
B) $\mathrm{H}_{2}$ gaz1
C) $\mathrm{Na}$
D) $\mathrm{K}$
E) $\mathrm{Cl}_{2}$ gazı

15. Yandaki elektroliz işleminde anotta ve katotta meydana gelen ürünler nelerdir? $\left(\mathrm{Al}^{3+}, \mathrm{H}_{2} \mathrm{O}, \mathrm{Br}_{2}, \mathrm{O}_{2}\right.$ nin standart indirgenme potansiyelleri arasındaki ilişki $\mathrm{Al}^{3+}<\mathrm{H}_{2} \mathrm{O}<\mathrm{Br}_{2}<\mathrm{O}_{2}$ şeklindedir.)

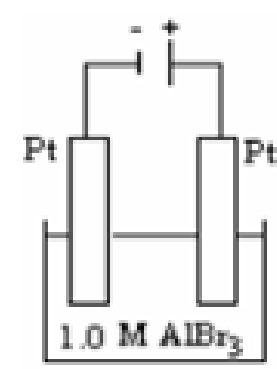


16. Suyun normal koşullardaki elektrolizi sonucunda anotta $15 \mathrm{~L}$ gaz toplanıyor. Buna göre katotta toplanan gazın cinsi ve miktar1 nedir? $\left(\mathrm{E}_{\mathrm{O} 2(\mathrm{~g}) / \mathrm{H} 2 \mathrm{O}}^{\mathrm{o}}=+1,23 \mathrm{~V} \mathrm{E}_{\mathrm{H}+\mathrm{H} 2(\mathrm{~g})}^{\mathrm{o}}\right.$ $=0,000 \mathrm{~V})$
A) Oksijen, $30 \mathrm{~L}$
B) Oksijen, $75 \mathrm{~L}$
C) Hidrojen, $15 \mathrm{~L}$
D) Hidrojen, $30 \mathrm{~L}$
E) Hidrojen, $75 \mathrm{~L}$

17. Bir bakır $(\mathrm{Cu})$ metal levha $1 \mathrm{M}^{\prime}$ lık bakır nitrat $\left(\mathrm{Cu}\left(\mathrm{NO}_{3}\right)_{2}\right)$ çözeltisine batırılırken, bir gümüş $(\mathrm{Ag})$ levha ise $1 \mathrm{M}^{\prime}$ lık gümüş nitrat $\left(\mathrm{AgNO}_{3}\right)$ çözeltisine batırılmıştır. İki metal levha bir voltmetreye iletken bir telle bağlanmış ve çözeltileri birbirine bağlamak için de tuz köprüsü kullanılmıştır. Aşağıdaki standart potansiyeller bilinmektedir.

$$
\begin{array}{ll}
\mathrm{Ag}^{+}{ }_{(\mathrm{aq})}+\mathrm{e}^{-} \longrightarrow \mathrm{Ag}_{(\mathrm{k})} & \mathrm{E}^{0}=+0,80 \mathrm{~V} \\
\mathrm{Cu}^{2+}{ }_{(\mathrm{aq})}+2 \mathrm{e}^{-} \longrightarrow \mathrm{Cu}_{(\mathrm{k})} & \mathrm{E}^{0}=+0,34 \mathrm{~V}
\end{array}
$$

Bu pilde aşağıdakilerden hangisi gerçekleşir?
A) Elektronlar dıştaki telden geçerek bakır elektrodun bulunduğu yarı pilden gümüş elektrodun bulunduğu yarı pile doğru hareket ederler.
B) Çözeltilerdeki pozitif ve negatif iyonlar, her iki yarı pilde derişimleri eşit oluncaya kadar tuz köprüsünden geçerek hareket ederler.
C) Ag levhada yükseltgenme olurken bakır levhada indirgenme olur.
D) Sadece negatif yüklü iyonlar tuz köprüsünden hareket ederler.
E) Sadece pozitif yüklü iyonlar tuz köprüsünden hareket ederler. 
18. Ege katıldığı bir bilim şenliği etkinliği sırasında gördüğü "Gümüş Ağacı” adlı bir projeyi çok beğenmiştir. Bu proje de bakır tel kullanılarak hazırlanan ağaç, şekil 1'deki beyaz renkli gümüş nitrat çözeltisine daldırılmıştır. Bir süre sonra şekil 2'deki görüntü elde edilmiştir.

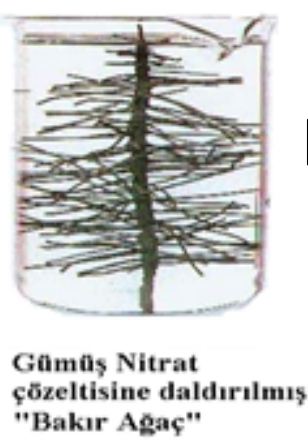

Şekil 1

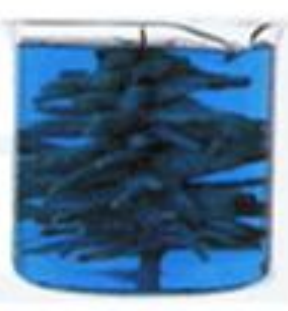

Şekil 2

Aşağıdaki ifadelerden hangisi bu durumu açıklamaktadır? $\left(\mathrm{E}_{\mathrm{Cu2}+/ \mathrm{Cu}(\mathrm{k})}^{\mathrm{o}}=+0,337\right.$ $\left.\mathrm{V}, \mathrm{E}_{\mathrm{Ag}+/ \mathrm{Ag}(\mathrm{k})}^{\mathrm{o}}=+0,799 \mathrm{~V}\right)$
A) Bakır indirgenerek çözeltiye geçerken çözeltideki gümüş iyonları bakır tel üzerinde metalik haline yükseltgenmiştir.
B) Bakır yükseltgenerek çözeltiye geçerken çözeltideki gümüş iyonları bakır tel üzerinde metalik Ag haline indirgenmiştir.
C) Bakır katot görevi görerek gümüş iyonlarını yükseltgemiştir.
D) Bakır, gümüş iyonları ile kompleks oluşturmuştur.
E) Gerçekleşen tepkime $\mathrm{Cu}_{(\mathrm{k})}+\mathrm{AgNO}_{3} \longrightarrow \mathrm{Cu}\left(\mathrm{NO}_{3}\right)_{2 \text { (suda) }}+\mathrm{Ag}_{(\mathrm{k})}+2 \mathrm{e}$ şeklindedir.

19. $\mathrm{KAuCI}_{4}$ çözeltisi içine daldırılan bir anahtar 0,5 Amper'lik akım kullanılarak altınla kaplanmak isteniyor. $591 \mathrm{mg}$ altın kaplama yapabilmek için elektroliz işlemi kaç saniye sürmelidir? (Au: $197 \mathrm{~g} / \mathrm{mol}$ )
A) 9.65
B) 28.95
C) 96.5
D) 289.5
E) 1737 
20. Utku'nun bir kimya laboratuarı dersinde aşağıda verilen maddelerden en büyük pozitif pil potansiyeli üreten bir pil düzeneği kurması gerekmektedir. Sizce Utku aşağıdaki şekilde numaralandırılan yerlerde hangi maddeleri kullanırsa en büyük pil potansiyelini elde eder?

$\left(\mathrm{E}_{\mathrm{A} 13+/ \mathrm{Al}(\mathrm{k})}^{\mathrm{o}}=-1,662 \mathrm{~V}, \mathrm{E}_{\mathrm{Cu} 2+/ \mathrm{Cu}(\mathrm{k})}^{\mathrm{o}}=+0,337 \mathrm{~V}, \mathrm{E}_{\mathrm{Fe} 2+/ \mathrm{Fe}(\mathrm{k})}^{\mathrm{o}}=-0,440 \mathrm{~V}, \mathrm{E}_{\mathrm{Ag}+/ \mathrm{Ag}(\mathrm{k})}^{\mathrm{o}}\right.$ $=+0,799 \mathrm{~V})$

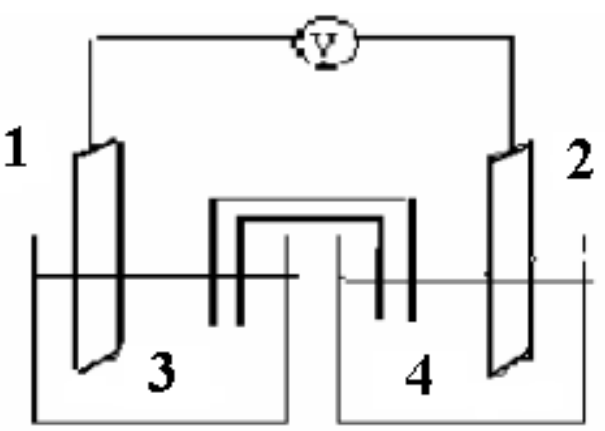

\section{Utku'nun sahip olduğu malzemeler:}

Al çubuk $\quad 0.1 \mathrm{M} \mathrm{Al}\left(\mathrm{NO}_{3}\right)_{3}$ çözeltisi

$\mathrm{Cu}$ çubuk $\quad 0.1 \mathrm{M} \mathrm{Cu}\left(\mathrm{NO}_{3}\right)_{2}$ çözeltisi

Fe çubuk $\quad 0.1 \mathrm{M} \mathrm{Fe}\left(\mathrm{NO}_{3}\right)_{2}$ çözeltisi

Ag çubuk $\quad 0.1 \mathrm{M} \mathrm{AgNO}_{3}$ çözeltisi

\begin{tabular}{lcccc} 
& $\mathbf{1}$ & $\mathbf{2}$ & $\mathbf{3}$ & $\mathbf{4}$ \\
\cline { 2 - 5 } A) & $\mathrm{Al}$ & $\mathrm{Fe}$ & $\mathrm{Al}\left(\mathrm{NO}_{3}\right)_{3}$ & $\mathrm{Fe}\left(\mathrm{NO}_{3}\right)_{2}$ \\
B) & $\mathrm{Al}$ & $\mathrm{Cu}$ & $\mathrm{Al}\left(\mathrm{NO}_{3}\right)_{3}$ & $\mathrm{Cu}\left(\mathrm{NO}_{3}\right)_{2}$ \\
C) & $\mathrm{Fe}$ & $\mathrm{Cu}$ & $\mathrm{Fe}\left(\mathrm{NO}_{3}\right)_{2}$ & $\mathrm{Cu}\left(\mathrm{NO}_{3}\right)_{2}$ \\
D) & $\mathrm{Ag}$ & $\mathrm{Al}$ & $\mathrm{AgNO} \mathrm{N}_{3}$ & $\mathrm{Al}\left(\mathrm{NO}_{3}\right)_{3}$ \\
E) & $\mathrm{Cu}$ & $\mathrm{Ag}$ & $\mathrm{Cu}\left(\mathrm{NO}_{3}\right)_{2}$ & $\mathrm{AgNO}$
\end{tabular}


21. Sibel kimya laboratuarı dersinde bakır bir malzemeyi gümüş ile kaplamak için aşağıda verilen malzemeleri kullanarak şekildeki düzeneği kurmuştur. Buna göre düzenekteki numaralar neleri temsil etmektedir?

Sibel'in sahip olduğu malzemeler:

Kaplanacak olan bakır malzeme $(\mathrm{Cu})$

Gümüş çubuk (Ag)

Pil

$0.1 \mathrm{M} \mathrm{Cu}\left(\mathrm{NO}_{3}\right)_{2}$ çözeltisi

$0.1 \mathrm{M} \mathrm{AgNO}_{3}$ çözeltisi

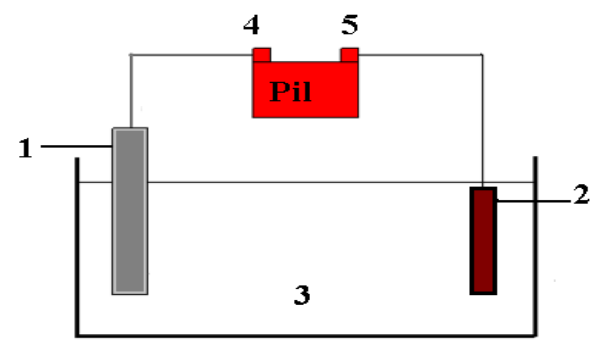

\begin{tabular}{lccccc} 
& $\mathbf{1}$ & $\mathbf{2}$ & $\mathbf{3}$ & $\mathbf{4}$ & $\mathbf{5}$ \\
\cline { 2 - 6 } A) & $\mathrm{Ag}$ & $\mathrm{Cu}$ & $\mathrm{Cu}\left(\mathrm{NO}_{3}\right)_{2}$ & - & + \\
B) & $\mathrm{Ag}$ & $\mathrm{Cu}$ & $\mathrm{Cu}\left(\mathrm{NO}_{3}\right)_{2}$ & + & - \\
C) & $\mathrm{Ag}$ & $\mathrm{Cu}$ & $\mathrm{AgNO}_{3}$ & + & - \\
D) & $\mathrm{Cu}$ & $\mathrm{Ag}$ & $\mathrm{AgNO}_{3}$ & + & - \\
E) & $\mathrm{Cu}$ & $\mathrm{Cu}$ & $\mathrm{AgNO}_{3}$ & - & +
\end{tabular}

22.

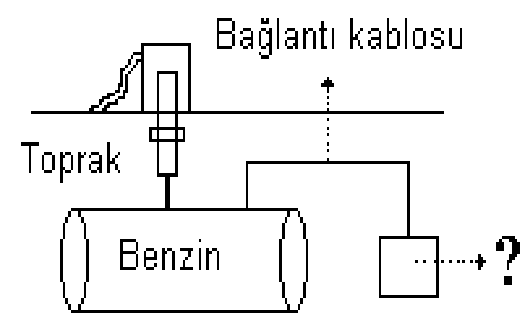

Boru hatları, gemiler, iskeleler, köprü ayakları, tanklar, kimyasal madde taşıyan kaplar, betonarme demirleri, su boruları, rafineriler ve petrol boru hatları katodik korumayla korozyondan korunabilir. Yandaki resimde demirden yapılmış yer altındaki benzin tankını korozyondan korumak amacıyla ? işareti ile gösterilen yere aşağıdaki metallerden hangisi konulmaz? $\left(\mathrm{E}_{\mathrm{Fe} 3+/ \mathrm{Fe}(\mathrm{k})}^{\mathrm{o}}=-0,040 \mathrm{~V}, \mathrm{E}_{\mathrm{Mg} 2+/ \mathrm{Mg}(\mathrm{k})}^{\mathrm{o}}=-2,863 \mathrm{~V}, \mathrm{E}_{\mathrm{Ni} 2+/ \mathrm{Ni}(\mathrm{k})}^{\mathrm{o}}=-0,250 \mathrm{~V}, \mathrm{E}_{\mathrm{Cu} 2+/ \mathrm{Cu}(\mathrm{k})}^{\mathrm{o}}=+0,337\right.$ $\left.\mathrm{V}, \mathrm{E}_{\mathrm{Al} 3+/ \mathrm{Al}(\mathrm{k})}^{\mathrm{o}}=-1,662 \mathrm{~V}, \mathrm{E}_{\mathrm{Zn} 2+/ \mathrm{Zn}(\mathrm{k})}^{\mathrm{o}}=-0,763 \mathrm{~V}\right)$
A) $\mathrm{Mg}$
B) $\mathrm{Ni}$
C) $\mathrm{Al}$
D) $\mathrm{Zn}$
E) $\mathrm{Cu}$ 
23.

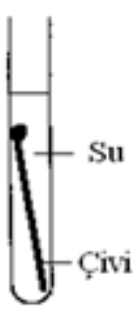

I

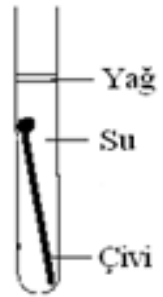

II

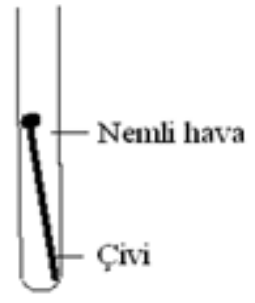

III

Yukarıda numaralandırılmış halde gösterilen deneylerden hangilerinde bir süre sonra demir çivinin paslandığı gözlemlenir?
A) Yalnız I
B) Yalnız II
C) Yalnız III
D) I ve III
E) I, II ve III

24.

$$
\begin{array}{ll}
\mathrm{Fe}^{2+}{ }_{\text {(suda) }}+2 \mathrm{e}^{-} \longrightarrow \mathrm{Fe}_{(\mathrm{k})} & \mathrm{E}^{0}=-0,440 \mathrm{~V} \\
\mathrm{Zn}^{2+}{ }_{\text {(suda) }}+2 \mathrm{e}^{-} \longrightarrow \mathrm{Zn}_{(\mathrm{k})} & \mathrm{E}^{0}=-0,763 \mathrm{~V} \\
\mathrm{O}_{2(\mathrm{~g})}+2 \mathrm{H}_{2} \mathrm{O}_{(\mathrm{s})}+4 \mathrm{e}^{-} \longrightarrow 4 \mathrm{OH}^{-} \text {(suda) } & \mathrm{E}^{0}=+0,40 \mathrm{~V}
\end{array}
$$

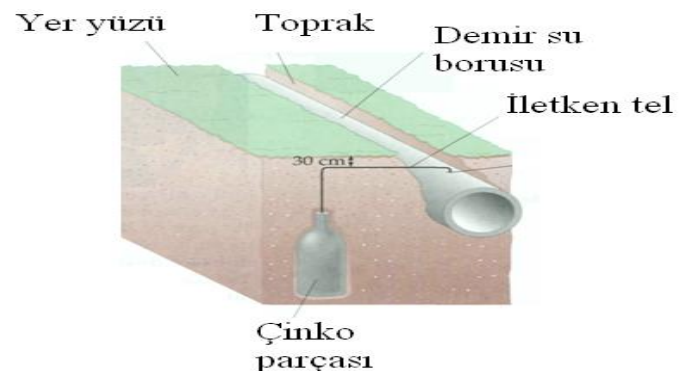

Yukarıdaki şekil yeraltından geçen demir su borusunun korozyondan korumak amacıyla iletken tel yardımıyla çinko parçasına bağlandığını göstermektedir. Yukarıdaki yarı reaksiyonlar dikkate alındığında aşağıdaki ifadelerden hangisi doğrudur?

A) Çinko parçası ile demir boru arasında indirgenme-yükseltgenme tepkimesi gerçekleşir.

B) Oksijen $\left(\mathrm{O}_{2}\right)$ çinko parçasının yüzeyinde indirgenir.

C) Demir borudaki $\mathrm{Fe}$ atomları $\mathrm{Fe}^{2+}$ haline yükseltgenir.

D) Demir boru ile Oksijen arasında indirgenme-yükseltgenme tepkimesi gerçekleşir.

E) Çinko parçası indirgenerek demir boru üzerinde birikir. 
25.

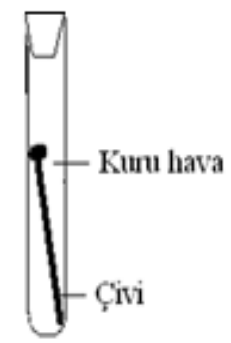

Yandaki şekilde görüldüğü gibi demir bir çivi kuru hava içeren bir deney tüpü içine yerleştirilerek tüpün ağzı sıkıca kapatılmıştır. Buna göre aşağıdaki ifadelerden hangisi doğrudur?
A) Çivide hiçbir değişiklik gözlemlenmez.
B) Bir süre sonra çivide paslanma gözlemlenir.
C) Havadaki oksijen indirgenirken demir yükseltgenir.
D) Hava ile demir arasında redoks tepkimesi gerçekleşir.
E) Demir çivi oksitlenerek korozyona uğrar.

26. Kararmış gümüş eşyalar $\left(\mathrm{Ag}_{2} \mathrm{~S}_{(\mathrm{k})}\right)$ içinde kabartma tozundan $\left(\mathrm{NaHCO}_{3}\right)$ hazırlanmış çözelti bulunan alüminyum ( $\mathrm{Al}$ ) bir kaba konulduğunda tekrar parlak hale $\left(\mathrm{Ag}_{(\mathrm{k})}\right)$ getirilmektedir. Bu işlem sırasında aşağıdaki reaksiyon gerçekleşmektedir.

$$
3 \mathrm{Ag}_{2} \mathrm{~S}_{(\mathrm{k})}+2 \mathrm{Al}_{(\mathrm{k})}+3 \mathrm{H}_{2} \mathrm{O}_{(\mathrm{s})} \longrightarrow 6 \mathrm{Ag}_{(\mathrm{k})}+\mathrm{Al}_{2} \mathrm{O}_{3(\mathrm{k})}+3 \mathrm{H}_{2} \mathrm{~S}_{\text {(suda) }}
$$

Buna göre gümüşün parlatılması işlemi ile ilgili aşağıdaki ifadelerden hangisi doğrudur?
A) Kararmış gümüş parçası anot görevi görür.
B) Çözeltideki $\mathrm{Al}^{+3}$ iyonları metalik $\mathrm{Al}$ haline indirgenir.
C) Kabartma tozu çözeltisi elektrolit görevi görür.
D) Kararmış gümüş parçasındaki sülfür iyonu yükseltgenir.
E) Alüminyum kararmış gümüşteki sülfür iyonlarını indirger. 
27.

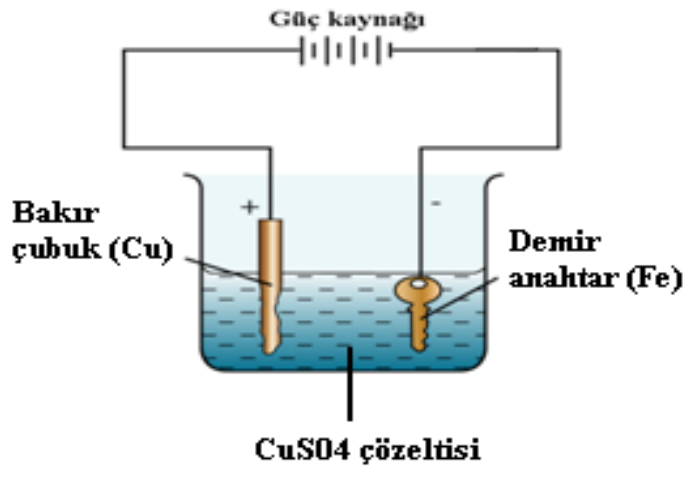

Yukarıdaki şekilde gösterilen olay ile ilgili aşağıdaki ifadelerden hangisi doğrudur?
A) Anahtardaki Fe atomları güç kaynağından gelen elektronları alarak indirgenir.
B) Zamanla bakır çubuğun kütlesinde artış olur.
C) Çözeltideki $\mathrm{Cu}^{+2}$ iyonları elektron alarak bakır çubuk üzerinde toplanır.
D) Zamanla demir anahtar üzerinde bakır atomları birikir.
E) Bakır çubuk katot görevi görür. 


\section{APPENDIX E}

\section{TABLE OF TEST SPECIFICATION}

\begin{tabular}{|c|c|c|c|c|c|c|}
\hline Item no & Knowledge & Comprehension & Application & Analysis & Synthesis & Evaluation \\
\hline 1 & & & $\mathrm{X}$ & & & \\
\hline 2 & & $\mathrm{X}$ & & & & \\
\hline 3 & & & $X$ & & & \\
\hline 4 & & $X$ & & & & \\
\hline 5 & & & $\mathrm{X}$ & & & \\
\hline 6 & & & $\mathrm{X}$ & & & \\
\hline 7 & & & $\mathrm{X}$ & & & \\
\hline 8 & & & & $X$ & & \\
\hline 9 & & & & $\mathrm{X}$ & & \\
\hline 10 & & & $\mathrm{X}$ & & & \\
\hline 11 & & & $\mathrm{X}$ & & & \\
\hline 12 & & & $\mathrm{X}$ & & & \\
\hline 13 & $X$ & & & & & \\
\hline 14 & & & & $\mathrm{X}$ & & \\
\hline 15 & & & & $\mathrm{X}$ & & \\
\hline 16 & & & $\mathrm{X}$ & & & \\
\hline 17 & & & & $\mathrm{X}$ & & \\
\hline 18 & & & $\mathrm{X}$ & & & \\
\hline 19 & & & $\mathrm{X}$ & & & \\
\hline 20 & & & & & $\mathrm{X}$ & \\
\hline 21 & & & & & $\mathrm{X}$ & \\
\hline 22 & & & & & & $\mathrm{X}$ \\
\hline 23 & & & & & & $\mathrm{X}$ \\
\hline 24 & & & & & & $\mathrm{X}$ \\
\hline 25 & & & $\mathrm{X}$ & & & \\
\hline 26 & & $\mathrm{X}$ & & & & \\
\hline 27 & & & & $\mathrm{X}$ & & \\
\hline
\end{tabular}




\section{APPENDIX F}

\section{ATTITUDE SCALE TOWARD CHEMISTRY}

\begin{tabular}{|c|c|c|c|c|c|c|}
\hline & & 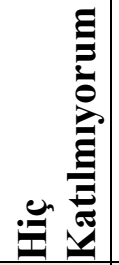 & E & 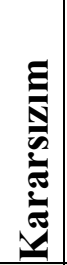 & 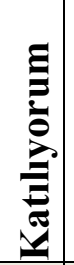 & 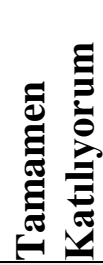 \\
\hline 1. & Kimya çok sevdiğim bir alandır. & & & & & \\
\hline 2. & $\begin{array}{l}\text { Kimya ile ilgili kitapları okumaktan } \\
\text { hoşlanırım. }\end{array}$ & & & & & \\
\hline 3. & $\begin{array}{l}\text { Kimyanın günlük hayatta çok önemli yeri } \\
\text { yoktur. }\end{array}$ & & & & & \\
\hline 4. & $\begin{array}{l}\text { Kimya ile ilgili ders problemlerini } \\
\text { çözmekten hoşlanırım. }\end{array}$ & & & & & \\
\hline 5. & $\begin{array}{l}\text { Kimya konuları ile ilgili daha çok şey } \\
\text { öğrenmek isterim. }\end{array}$ & & & & & \\
\hline 6. & Kimya dersine girerken sıkıntı duyarım. & & & & & \\
\hline 7. & Kimya derslerine zevkle girerim. & & & & & \\
\hline 8. & $\begin{array}{l}\text { Kimya dersine ayrilan ders saatinin daha } \\
\text { çok olmasını isterim. }\end{array}$ & & & & & \\
\hline 9. & Kimya dersine çalışırken canım sıkılır. & & & & & \\
\hline 10 . & $\begin{array}{l}\text { Kimya konularını ilgilendiren günlük } \\
\text { olaylar hakkında daha fazla bilgi edinmek } \\
\text { isterim. }\end{array}$ & & & & & \\
\hline 11. & $\begin{array}{l}\text { Düşünce sistemimizi geliştirmede Kimya } \\
\text { öğrenimi önemlidir. }\end{array}$ & & & & & \\
\hline 12. & $\begin{array}{l}\text { Kimya çevremizdeki doğal olayların daha } \\
\text { iyi anlaşılmasında önemlidir. }\end{array}$ & & & & & \\
\hline 13. & $\begin{array}{l}\text { Dersler içerisinde Kimya dersi sevimsiz } \\
\text { gelir. }\end{array}$ & & & & & \\
\hline 14. & $\begin{array}{l}\text { Kimya konuları ile ilgili tartışmaya } \\
\text { katılmak bana cazip gelmez. }\end{array}$ & & & & & \\
\hline 15. & $\begin{array}{l}\text { Çalışma zamanının önemli bir kısmını } \\
\text { Kimya dersine ayırmak isterim. }\end{array}$ & & & & & \\
\hline
\end{tabular}




\section{APPENDIX G}

CHEMISTRY MOTIVATION QUESTIONNAIRE

\begin{tabular}{|c|c|c|c|c|c|c|}
\hline & & 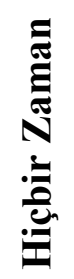 & 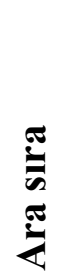 & 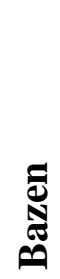 & & 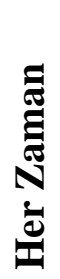 \\
\hline 1. & $\begin{array}{l}\text { Öğrendiğim kimya bilgisi benim kişisel } \\
\text { hedeflerimle ilişkilidir. }\end{array}$ & & & & & \\
\hline 2. & Kimya öğrenmeyi ilginç bulurum. & & & & & \\
\hline 3. & $\begin{array}{l}\text { Kimyayı öğrenmenin iyi bir iş bulmada bana } \\
\text { nasıl yardımcı olacağını düşünürüm. }\end{array}$ & & & & & \\
\hline 4. & Öğrendiğim kimya hayatımla ilişkilidir. & & & & & \\
\hline 5. & $\begin{array}{l}\text { Benim için kimyayı öğrenmek aldığım nottan } \\
\text { daha önemlidir. }\end{array}$ & & & & & \\
\hline 6. & $\begin{array}{l}\text { Kimya öğrenmenin kariyerime nasıl faydası } \\
\text { olacağını düşünürüm. }\end{array}$ & & & & & \\
\hline 7. & $\begin{array}{l}\text { Öğrendiğim kimyanın benim için pratik değeri } \\
\text { vardır. }\end{array}$ & & & & & \\
\hline 8. & $\begin{array}{l}\text { Öğrendiğim kimyayı nasıl kullanacağımı } \\
\text { düşünürüm. }\end{array}$ & & & & & \\
\hline 9. & Kimyayı anlayamıyorsam bu benim hatamdır. & & & & & \\
\hline 10. & $\begin{array}{l}\text { Öğrendiğim kimya bilgisinin bana nasıl } \\
\text { faydası olacağını düşünürüm. }\end{array}$ & & & & & \\
\hline 11. & Beni zorlayan kimya hoşuma gider. & & & & & \\
\hline
\end{tabular}




\section{APPENDIX H}

\section{HIGH SCHOOL CHEMISTRY SELF-EFFICACY SCALE}

\begin{tabular}{|c|c|c|c|c|c|c|c|c|c|c|}
\hline & & $\frac{N}{0}$ & & 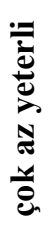 & & 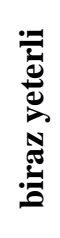 & & 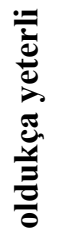 & & 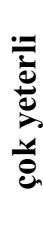 \\
\hline 1. & $\begin{array}{l}\text { Kimya kanun ve teorilerini ne } \\
\text { derecede açılayabilirsiniz? }\end{array}$ & 1 & 2 & 3 & 4 & 5 & 6 & 7 & 8 & 9 \\
\hline 2. & $\begin{array}{l}\text { Kimya problemlerini çözerken uygun } \\
\text { formül kullanmada ne kadar iyisiniz? }\end{array}$ & 1 & 2 & 3 & 4 & 5 & 6 & 7 & 8 & 9 \\
\hline 3. & $\begin{array}{l}\text { Laboratuvarda deney prosedürünü } \\
\text { uygulamada ne kadar iyisiniz? }\end{array}$ & 1 & 2 & 3 & 4 & 5 & 6 & 7 & 8 & 9 \\
\hline 4. & $\begin{array}{l}\text { Laboratuvar araç-gereçlerini ne kadar } \\
\text { iyi kullanabilirsiniz? }\end{array}$ & 1 & 2 & 3 & 4 & 5 & 6 & 7 & 8 & 9 \\
\hline 5. & $\begin{array}{l}\text { Kimya ve diğer bilimler arasında } \\
\text { ilişki kurmada ne kadar iyisiniz? }\end{array}$ & 1 & 2 & 3 & 4 & 5 & 6 & 7 & 8 & 9 \\
\hline 6. & $\begin{array}{l}\text { Atomun yapısını tasvir etmede ne } \\
\text { kadar iyisiniz? }\end{array}$ & 1 & 2 & 3 & 4 & 5 & 6 & 7 & 8 & 9 \\
\hline 7. & $\begin{array}{l}\text { Laboratuvar sırasında verileri } \\
\text { yorumlamada ne kadar iyisiniz? }\end{array}$ & 1 & 2 & 3 & 4 & 5 & 6 & 7 & 8 & 9 \\
\hline 8. & $\begin{array}{l}\text { Periyodik tabloyu kullanarak } \\
\text { elementlerin özelliklerini } \\
\text { tanımlamada ne kadar iyisiniz? }\end{array}$ & 1 & 2 & 3 & 4 & 5 & 6 & 7 & 8 & 9 \\
\hline 9. & $\begin{array}{l}\text { Element ve bileşiklerin formüllerini } \\
\text { okumada ne kadar iyisiniz? }\end{array}$ & 1 & 2 & 3 & 4 & 5 & 6 & 7 & 8 & 9 \\
\hline 10. & $\begin{array}{l}\text { Kimyasal denklemleri yorumlamada } \\
\text { ne kadar iyisiniz? }\end{array}$ & 1 & 2 & 3 & 4 & 5 & 6 & 7 & 8 & 9 \\
\hline 11. & $\begin{array}{l}\text { Maddenin tanecikli yapısını } \\
\text { açıklamada ne kadar iyisiniz? }\end{array}$ & 1 & 2 & 3 & 4 & 5 & 6 & 7 & 8 & 9 \\
\hline 12. & $\begin{array}{l}\text { Laboratuvar düzeneğini ne kadar iyi } \\
\text { kurabilirsiniz? }\end{array}$ & 1 & 2 & 3 & 4 & 5 & 6 & 7 & 8 & 9 \\
\hline 13. & $\begin{array}{l}\text { Kimyadaki temel kavramları } \\
\text { tanımlamada ne kadar iyisiniz? }\end{array}$ & 1 & 2 & 3 & 4 & 5 & 6 & 7 & 8 & 9 \\
\hline 14. & $\begin{array}{l}\text { Kimya ile ilgili grafik ve çizelgeleri } \\
\text { yorumlamada ne kadar iyisiniz? }\end{array}$ & 1 & 2 & 3 & 4 & 5 & 6 & 7 & 8 & 9 \\
\hline 15. & $\begin{array}{l}\text { Laboratuvar sırasında veri toplamada } \\
\text { ne kadar iyisiniz? }\end{array}$ & 1 & 2 & 3 & 4 & 5 & 6 & 7 & 8 & 9 \\
\hline 16. & $\begin{array}{l}\text { Temel bulguları özetleyen laboratuvar } \\
\text { raporu yazmada ne kadar iyisiniz? }\end{array}$ & 1 & 2 & 3 & 4 & 5 & 6 & 7 & 8 & 9 \\
\hline
\end{tabular}




\section{APPENDIX I}

\section{FEEDBACK FORM FOR CASE-BASED INSTRUCTION}

Ad1 Soyadi:

Okul adı:

Sinıfi:

Okul No:

Açıklama: Aşağıda verilen sorular Örnek Olaya Dayalı Öğrenme Modeline ilişkin görüşlerinizi belirlemek için hazırlanmıştır. Bu nedenle verdiğiniz cevaplar örnek olaya dayalı öğrenme modelinin ileride etkili bir şekilde uygulanabilmesi için büyük önem taşımaktadır. Lütfen her soruyu dikkatlice okuyarak, görüşlerinizi içtenlikle belirtiniz.

Teşekkürler.

1. Örnek Olaya Dayalı Öğrenme Modelini nasıl tanımlarsınız? Sizce Örnek Olaya Dayalı Öğrenme Modelinin karakteristik özellikleri nelerdir? 
2. Örnek olaya dayalı öğrenme modeli elektrokimya konusunu öğrenmede etkili bir yöntem midir? Neden?

3. Örnek Olaya Dayalı Öğrenme Modelinde en çok hoşunuza giden özellik ya da özellikler nelerdir?

4. Örnek Olaya Dayalı Öğrenme Modelinde hangi özelliği ya da özellikleri kesinlikle değiştirmek isterdiniz? 
5. Ders sırasında işlenen örnek olaylar hakkındaki görüşleriniz nelerdir?

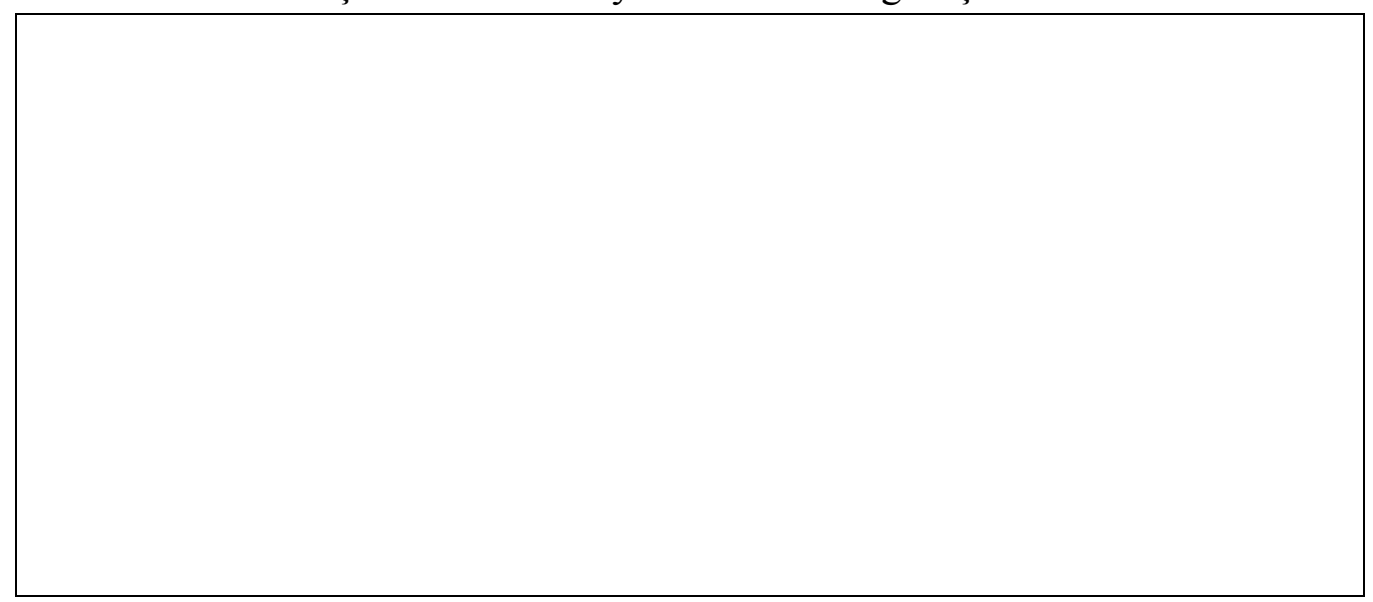

6. Örnek Olaya Dayalı Öğrenme Modelinin uygulanması sırasında herhangi bir zorlukla karşılaştınız mı?

7. Örnek Olaya Dayalı Öğrenme Modelinin grup çalışması şeklinde uygulanması hakkında neler düşünüyorsunuz? 


\section{KIMYA DERSI HAKKINDAKİ GÖRÜŞLERINIIZ}

Açıklama: Aşağıda verilen sorular Kimya derslerinize ilişkin görüşlerinizi belirlemek için hazırlanmıştır. Bu nedenle verdiğiniz cevaplar kimya öğretiminin ileride daha etkili bir şekilde yapılabilmesi için büyük önem taşımaktadır. Lütfen her soruyu dikkatlice okuyarak, görüşlerinizi içtenlikle belirtiniz. Teşekkürler.

1. Elektrokimya konusunda yapılan öğretimi daha önceki kimya derslerinde yapılan öğretimle kıyaslandığınızda ne tür benzerlikleri ve farklılıkları vardır?

2. Elektrokimya konusunda yapılan öğretimi daha önceki kimya derslerinde yapılan öğretimle kıyaslandığınızda size sağladığı katkılar hakkında neler düşünüyorsunuz? 


\section{APPENDIX J}

\section{A SAMPLE CASE (STUDENT VERSION)}

\section{GÜMÜŞ EŞYALAR}

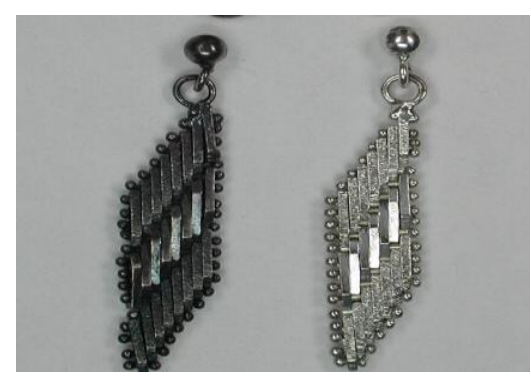

Simge gümüss takı kullanmayı çok sevmektedir. Simge'nin birçok gümüş küpeleri, kolyeleri ve bileklikleri vardır. Fakat Simge bu gümüş takılarının zamanla parlaklığını kaybedip kararmasından çok şikayetçidir. Bir gün bu konudaki sıkıntısını arkadaşı Burcu ile paylaşır.

Burcu: Benim gümüş takılarım yok ama evde gümüş eşyalarımız var, onlar da zamanla karariyor.

Simge: Neden kararıyor biliyor musun?

Burcu: Hayır, bilmiyorum.

Simge: Peki eşyalarınız karardığında ne yapıyorsunuz?

Burcu: Gümüş eşyalar satan bir dükkan var, ona götürüp parlattırıyoruz.

Simge: Nasıl temizleniyor? Benim gümüş takılarım da temizlenip eskisi gibi parlar $\mathrm{m}$ ?

Burcu: Tabi ki, senin takıların da parlar. İstersen bizim gümüş eşyaları parlattırdı̆̆ımız yere gidebiliriz.

Simge: Evet, gidelim çok iyi olur. Yaşasın, benim takılarımda eskisi gibi parlayacak!

(Burcu ve Simge gümüşçü dükkanına gider. Simge dükkan sahibine gümüş takılarını göstererek bunları parlatabilir misiniz diye sorar).

Dükkan sahibi: Tabii ki parlatırım. Gümüş takıların ilk aldığın gibi olacak.

Simge: Nasıl yapiyorsunuz bunu?

Dükkan sahibi: Nasıl yaptığımı görmek ister misin?

Simge: Evet, çok isterim.

Dükkan sahibi: Benden tarafa gel istersen, nasıl yaptığımı görürsün.

Simge: Tamam. 
(Dükkan sahibi alüminyum folyo ile kaplı bir kap içerisine Simge'nin gümüş takılarını koyar ve üzerine sodyum bikarbonat içeren sıcak sıvıyı döker.

Takılar bu sıvı içerisinde bir süre durduktan sonra dükkan sahibi takıları kap içerisinden çıkarıp kurulayarak Simge'ye gösterir).

Simge: Yaşasın! Çok güzel parlıyorlar. Teşekkür ederim.

Dükkan sahibi: Ama bir süre sonra tekrar parlaklığı gider ve yine kararır.

Karardığında tekrar gelirsen yine parlatırım.

Simge: Tamam.

(Simge ve Burcu dükkandan ayrllarak evlerine doğru giderler)

Simge: Aslında belki parlatma olayını biz de yapabiliriz.

Burcu: Nasıl yapacağız?

Simge: Haydi araştıralım!

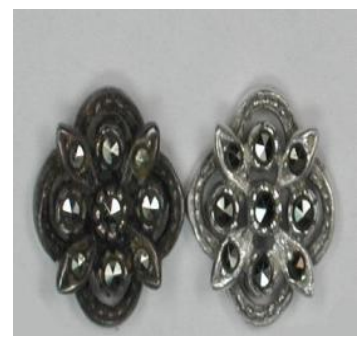

\section{SORULAR}

1. Gümüş eşyalar neden bir süre sonra parlaklığını kaybedip kararırlar? Bu olayı açıklayan kimyasal tepkimeyi yazabilir misiniz? Yükseltgenen ve indirgenen maddeler nelerdir, bunlara ait yarı reaksiyon denklemlerini yazınız?

2. Sizce gümüş eşyalarımızı kendimiz de parlatabilir miyiz? Sizde bir gümüş eşyanızı parlatmak için bir deney yapınız.

3. Gümüş takıların parlatılması olayını açıklayan kimyasal tepkimeyi yazabilir misiniz? Yükseltgenen ve indirgenen maddeler nelerdir bunlara ait yarı reaksiyon denklemlerini yazınız?

4. Gümüş takıların temizlenmesi sırasında kullanılan sodyum bikarbonat çözeltisinin görevi nedir? Bu çözeltinin sıcak olmasının nedeni var midır? Eğer varsa sizce nedeni nedir?

5. Gümüş takıların temizlenmesi sırasında neden alüminyum folyo seçilmiştir? Alüminyum folyonun görevi nedir? Alüminyum folyo yerine başka bir madde de kullanılabilir miydi?

6. Bakır eşyaların üzerinde de zamanla yeşil renkler oluşmaktadır. Sizce bunun nedeni ne olabilir? Bu olayı açıklayan kimyasal tepkimeyi yazabilir misiniz? Yükseltgenen ve indirgenen maddeler nelerdir, bunlara ait yarı reaksiyon denklemlerini yazınız? 


\section{APPENDIX K}

\section{A SAMPLE CASE (TEACHER VERSION)}

\section{Kazanımlar:}

1. Redoks tepkimelerinin denklemleri üzerinde indirgenen ve yükseltgenen türleri belirler.

2. Redoks denklemlerini denkleştirir.

\section{GÜMÜŞ EŞYALAR}

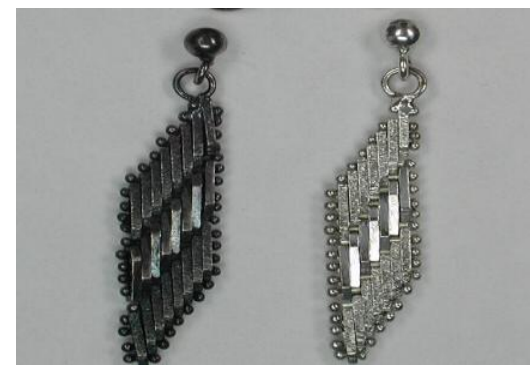

Simge gümüss takı kullanmayı çok sevmektedir. Simge'nin birçok gümüş küpeleri, kolyeleri ve bileklikleri vardır. Fakat Simge bu gümüş takılarının zamanla parlaklı̆̆ını kaybedip kararmasından çok şikayetçidir. Bir gün bu konudaki sıkıntısını arkadaşı Burcu ile paylaşır.

Burcu: Benim gümüş takılarım yok ama evde gümüş eşyalarımız var, onlar da zamanla karariyor.

Simge: Neden kararıyor biliyor musun?

Burcu: Hayır, bilmiyorum.

Simge: Peki eşyalarınız karardığında ne yapıyorsunuz?

Burcu: Gümüş eşyalar satan bir dükkan var, ona götürüp parlattırıyoruz.

Simge: Nasıl temizleniyor? Benim gümüş takılarım da temizlenip eskisi gibi parlar $\mathrm{m}$ ?

Burcu: Tabi ki, senin takıların da parlar. İstersen bizim gümüş eşyaları parlattırdı ğımız yere gidebiliriz.

Simge: Evet, gidelim çok iyi olur. Yaşasın, benim takılarımda eskisi gibi parlayacak!

(Burcu ve Simge gümüşçü dükkanına gider. Simge dükkan sahibine gümüş takılarını göstererek bunları parlatabilir misiniz diye sorar).

Dükkan sahibi: Tabii ki parlatırım. Gümüş takıların ilk aldığın gibi olacak. Simge: Nasıl yapıyorsunuz bunu? 
Dükkan sahibi: Nasıl yaptığımı görmek ister misin?

Simge: Evet, çok isterim.

Dükkan sahibi: Benden tarafa gel istersen, nasıl yaptı̆̆ımı görürsün.

Simge: Tamam.

(Dükkan sahibi alüminyum folyo ile kaplı bir kap içerisine Simge'nin gümüş

takılarını koyar ve üzerine sodyum bikarbonat içeren sıcak sıvıyı döker.

Takılar bu sıvı içerisinde bir süre durduktan sonra dükkan sahibi takıları kap içerisinden çıkarıp kurulayarak Simge'ye gösterir).

Simge: Yaşasın! Çok güzel parlıyorlar. Teşekkür ederim.

Dükkan sahibi: Ama bir süre sonra tekrar parlaklığg gider ve yine kararır.

Karardığında tekrar gelirsen yine parlatırım.

Simge: Tamam.

(Simge ve Burcu dükkandan ayrllarak evlerine doğru giderler)

Simge: Aslında belki parlatma olayını biz de yapabiliriz.

Burcu: Nasıl yapacağız?

Simge: Haydi araştıralım!

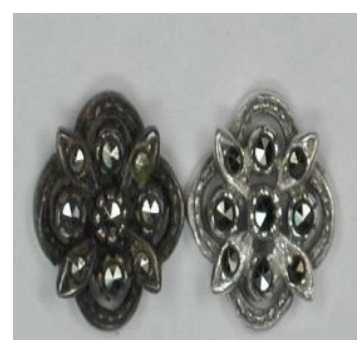

\section{SORULAR}

1. Gümüş eşyalar neden bir süre sonra parlaklığını kaybedip kararırlar? Bu olayı açıklayan kimyasal tepkimeyi yazabilir misiniz? Yükseltgenen ve indirgenen maddeler nelerdir, bunlara ait yarı reaksiyon denklemlerini yazınız?

2. Sizce gümüş eşyalarımızı kendimiz de parlatabilir miyiz? Sizde bir gümüş eşyanızı parlatmak için bir deney yapınız.

3. Gümüş takıların parlatılması olayını açıklayan kimyasal tepkimeyi yazabilir misiniz? Yükseltgenen ve indirgenen maddeler nelerdir bunlara ait yarı reaksiyon denklemlerini yazınız?

4. Gümüş takıların temizlenmesi sırasında kullanılan sodyum bikarbonat çözeltisinin görevi nedir? Bu çözeltinin sıcak olmasının nedeni var midır? Eğer varsa sizce nedeni nedir?

5. Gümüş takıların temizlenmesi sırasında neden alüminyum folyo seçilmiştir? Alüminyum folyonun görevi nedir? Alüminyum folyo yerine başka bir madde de kullanılabilir miydi?

6. Bakır eşyaların üzerinde de zamanla yeşil renkler oluşmaktadır. Sizce bunun nedeni ne olabilir? Bu olayı açıklayan kimyasal tepkimeyi yazabilir misiniz? Yükseltgenen ve indirgenen maddeler nelerdir, bunlara ait yarı reaksiyon denklemlerini yazınız? 


\section{Sınıf içinde yapılacaklar}

- Öğrenciler daha önceden belirlenmiş gruplarını oluştururlar.

- Metin ve sorular öğrencilere dağıtılır.

- Dağıtılan metin öğrenciler arasından seçilecek 2 kişi tarafından diyalog şeklinde okunacaktır.

- Daha sonra öğrenciler gruplar halinde metin sonundaki soruları yaparak cevaplarını bir kâğıda yazacaklardır (Her gruptan cevap kağıdının üzerine gruptaki öğrencilerin isimlerini yazmaları istenir).

- Daha sonra bütün grupların sorulara verdikleri cevaplar sırasıyla tek tek dinlenir ve verilen cevaplar sınıfça tartışılır. Metindeki sorular ve cevapları aşağıdadır.

1. Gümüş eşyalar neden bir süre sonra parlaklığını kaybedip kararırlar? Bu olayı açıklayan kimyasal tepkimeyi yazabilir misiniz? Yükseltgenen ve indirgenen maddeler nelerdir, bunlara ait yarı reaksiyon denklemlerini yazınız?

Öğrenciler gümüşün oksijenle tepkimeye girdiğini düşünebilirler. Fakat gümüşün oksitlenmesi oldukça zordur. Böyle düşünen öğrenciler olursa onlara gümüşün oksitlenmesinin kolay olup olmadığını sorunuz. Öğrenciler bir süre düşündükten sonra onlara gümüşün hava ortamında kükürtten çok kolay etkilendiğini ve bu yüzden karardığını söyleyebilirsiniz.

Gümüş havadaki kükürt, kükürtlü hidrojen $\left(\mathrm{H}_{2} \mathrm{~S}\right)$, kükürt dioksit gazlarının etkisi altında ya da gümüş bir eşyanın, kükürt bakımından zengin bir maddeyle (yumurta sarısı, kükürtlü kauçuk) teması sırasında kararma oluşur. Arabaların egzoz gazlarından sobalardan çıkan dumanda ve doğalgazda bulunan kükürt gümüşü etkilemektedir. Öğrencilerinizden tepkimeyi tahtaya yazmalarını isteyiniz (Öğrencilerinize grup çalışması sırasında hava ortamı içerisinde kükürtten dolayı gümüşlerin karardığı ipucunu verebilirsiniz).

$\mathrm{Ag}_{(\mathrm{k})}+\mathrm{O}_{2}+\mathrm{H}_{2} \mathrm{~S}_{(\mathrm{g})} \longrightarrow$ bunun sonucunda ne tür maddelerin oluşacağını sorunuz.

Denkleştirilmemiş hali:

$$
\mathrm{Ag}_{(\mathrm{k})}+\mathrm{O}_{2}+\mathrm{H}_{2} \mathrm{~S}_{(\mathrm{g})} \longrightarrow \mathrm{Ag}_{2} \mathrm{~S}_{(\mathrm{k})}+\mathrm{H}_{2} \mathrm{O}_{(\mathrm{g})}
$$

Daha sonra öğrencilerinizden tepkimeyi denkleştirmelerini isteyiniz, bir öğrenciden denkleştirilmiş halini tahtaya yazmasını isteyiniz

Denkleştirilmiş hali:

$$
4 \mathrm{Ag}_{(\mathrm{k})}+\mathrm{O}_{2}+2 \mathrm{H}_{2} \mathrm{~S}_{(\mathrm{g})} \longrightarrow 2 \mathrm{Ag}_{2} \mathrm{~S}_{(\mathrm{k})}+2 \mathrm{H}_{2} \mathrm{O}_{(\mathrm{g})}
$$


Gümüş(Ag) yükseltgenirken, Oksijen indirgenir (Öğrencilerinize sorarak cevaplandırırınız). Öğrencilerin birinden yarı reaksiyonları tahtaya yazmasını isteyiniz.

Yükseltgenme yarı reaksiyon: $2 \mathrm{Ag} \longrightarrow 2 \mathrm{Ag}^{+}+2 \mathrm{e}^{-}$

İndirgenme yarı reaksiyon: $\mathrm{O}_{2}+4 \mathrm{e}^{-} \longrightarrow 2 \mathrm{O}^{-2}$

2. Bir gümüş eşyanın metinde belirtilen şekilde temizleme deneyi yapılır. Deney için gerekli olan sodyum bikarbonat çözeltisini nasıl edinebileceğimizi öğrencilerinize sorunuz. Günlük hayatta kullandığımız hangi madde içinde sodyum bikarbonat vardır diye öğrencilerinize sorunuz (Hamur kabartma tozu olarak kullandığımız madde sodyum bikarbonattan oluşmaktadır).

Sicak sodyum bikarbonat çözeltisine (bunun için kabartma tozu kullanılacak) parlaklığını yitirmiş bir gümüş eşya atılarak bir süre beklenir. Daha sonra gümüş eşya çözelti içinden çıkartılarak önce su ile yıkanıp (çünkü üzerinde sodyum bikarbonat tuzu olabilir) sonra da kurulanıp öğrencilere gösterilir (Yapılan işlem sonucunda gümüş eşyanın eskiye göre daha parlak olması beklenir).

3. Gümüş takıların parlatılması olayını açıklayan kimyasal tepkimeyi yazabilir misiniz? Yükseltgenen ve indirgenen maddeler nelerdir bunlara ait yarı reaksiyon denklemlerini yazınız?

Öğrenciler aşağıdaki cevabı verebilir. Bu durumda öğrencilere bu reaksiyon ifadesinin doğru yazılıp yazılmadığını sorunuz.

$\mathrm{Ag}_{2} \mathrm{~S}_{(\mathrm{k})}+\mathrm{Al}_{(\mathrm{k})} \longrightarrow \mathrm{Ag}_{(\mathrm{k})}+\mathrm{Al}_{2} \mathrm{~S}_{3 \text { (suda) }}$

Onlardan tepkimeyi denkleştirmelerini isteyiniz. Nasıl denkleştirileceğini sınıfa sorarak bir öğrenciden bunu yapmasını isteyiniz. Sınıfa doğru yapıp yapmadığını sorunuz.

Denkleştirilmiş tepkime:

$3 \mathrm{Ag}_{2} \mathrm{~S}_{(\mathrm{k})}+2 \mathrm{Al}_{(\mathrm{k})} \longrightarrow 6 \mathrm{Ag}_{(\mathrm{k})}+\mathrm{Al}_{2} \mathrm{~S}_{3 \text { (suda) }}$

Ayrıca öğrencilerden elektron alış verişini göstererek de tepkimeyi denkleştirmelerini isteyiniz. Bir öğrenciden bunu tahta da yapmasını (denemesini) isteyiniz. Sınıfa öğrencinin yaptığının doğru olup olmadığını sorunuz. 
Yükseltgenme yarı reaksiyonu: $3 / \mathrm{Ag}_{2} \mathrm{~S}+2 \mathrm{e}^{-} \longrightarrow 2 \mathrm{Ag}$ $\begin{array}{lc}\text { Indirgenme yarı reaksiyonu: } & 2 \mathrm{Al} \longrightarrow 2 \mathrm{Al}_{2} \mathrm{~S}_{3}+6 \mathrm{e}^{-} \\ 3 \mathrm{Ag}_{2} \mathrm{~S}+2 \mathrm{Al} \longrightarrow 6 \mathrm{Ag}+2 \mathrm{Al}_{2} \mathrm{~S}_{3}\end{array}$

Sınıfla beraber yarı reaksiyon yöntemi ile denkleştirmenin nasıl yapılacağını gösteriniz.

Gerçek tepkime şu şekildedir (öğrenciler bu denklemi yazamayabilir):

$\mathrm{Ag}_{2} \mathrm{~S}_{(\mathrm{k})}+\mathrm{Al}_{(\mathrm{k})} \longrightarrow \mathrm{Ag}_{(\mathrm{k})}+\mathrm{Al}^{+3}$ (suda) $+\mathrm{H}_{2} \mathrm{~S}_{(\mathrm{g})}$ (bazik ortam) Öğrencilere gerçekte yukarıdaki tepkimenin olduğunu söyleyerek (tahtaya yazarak) onlardan bu denklemi gruplariyla beraber denkleştirmelerini isteyiniz.

Denkleştirilmiş tepkime:

$3 \mathrm{Ag}_{2} \mathrm{~S}_{(\mathrm{k})}$
$6 \mathrm{OH}_{(\text {suda })}^{-}$

Gruplardan yarı tepkime yöntemi ile tepkimeyi nasıl denkleştirdiklerini göstermelerini isteyiniz. Her grubun çalışmasını kontrol ederek gerektiği yerde onları yönlendiriniz. Rastgele bir gruptan bir öğrenciyi seçerek denklemi tahtada denkleştirmesini isteyiniz. Eğer yanlış yapıyorsa sınıftan başka bir öğrencinin onu yönlendirmesini (ona yardımcı olmasını) isteyiniz.

4. Gümüş takıların temizlenmesi sırasında kullanılan sodyum bikarbonat çözeltisinin görevi nedir? Bu çözeltinin sıcak olmasının nedeni var mıdır? Eğer varsa sizce nedeni nedir?

Elektrolit görevi görür (Burada elektrolit tanımı verilebilir). Tepkime için gerekli bazik ortamı sağlar. Çözeltinin sıcak olması tepkimenin daha hılı gerçekleşmesini sağlar yani kararmış gümüşün daha çabuk temizlenmesini sağlar (Öğrencilerin bu durumu daha önce öğrenmiş oldukları reaksiyon hızı kavramı ile açıklamaları beklenir).

5. Gümüş takıların temizlenmesi sırasında neden alüminyum folyo seçilmiştir? Alüminyum folyonun görevi nedir? Alüminyum folyo yerine başka bir madde de kullanılabilir miydi? 
Alüminyum gümüşten daha aktif bir metal olduğu için sülfür ile gümüşü ayırır ve Alüminyum folyodaki $\mathrm{Al}$ metali $\mathrm{Ag}_{2} \mathrm{~S}$ deki gümüş iyonunu metalik hale $(\mathrm{Ag})$ indirger.

Gümüşten daha aktif olan bir metali kullanabiliriz aktifliği ne kadar çok olursa sülfürün ayrılması o kadar kolay olur (Öğrencilerin bu soruya cevap verirken daha önce öğrenmiş oldukları aktiflik kavramını kullanmaları beklenir).

6. Bakır eşyaların üzerinde de zamanla yeşil renkler oluşmaktadır. Sizce bunun nedeni ne olabilir? Bu olayı açıklayan kimyasal tepkimeyi yazabilir misiniz? Yükseltgenen ve indirgenen maddeler nelerdir, bunlara ait yarı reaksiyon denklemlerini yazınız?

Sarımsı pembe renkte olan saf bakır, havayla karşılaştığında incecik bir katman halinde metal yüzeyinde oluşan bakır oksit nedeniyle, rengi kızıl kahverengiye döner.

$2 \mathrm{Cu}_{(\mathrm{k})}+\mathrm{O}_{2(\mathrm{~g})} \longrightarrow 2 \mathrm{CuO}_{(\mathrm{k})}$

Bakır yükseltgenir, havadaki oksijen indirgenir. Öğrencilerinizden yarı reaksiyon denklemlerini tahtaya yazmalarını isteyiniz.

$2 / \mathrm{Cu} \longrightarrow \mathrm{Cu}^{+2}+2 \mathrm{e}^{-}$

$\mathrm{O}_{2}+4 \mathrm{e}^{-} \longrightarrow 2 \mathrm{O}^{-2}$

$2 \mathrm{Cu}+\mathrm{O}_{2} \longrightarrow 2 \mathrm{CuO}$

Metal havayla temas etmeyi sürdürdükçe bakır oksit bu kez havadaki $\mathrm{CO}_{2}$ ile birleşerek bakır karbonata $\left(\mathrm{Cu}_{2} \mathrm{CO}_{3}(\mathrm{OH})_{2}\right)$ ya da $\mathrm{SO}_{2}$ ile birleşerek bakır sülfata $\left(\mathrm{Cu}_{4} \mathrm{SO}_{4}(\mathrm{OH})_{6}\right)$ dönüşeceğinden metalin yüzeyi zamanla yeşil bir renk alır. Bakırpası ya da patina denen bu katman, çok ince bir katman olmasına karşın alttaki metali diğer kimyasal etkenlerden korur.

NOT: Bakır oksit Hidrojen gazına maruz bırakılırsa tekrar eski parklığını, rengini kazanır (Bu bilgi öğrencilere verilerek öğrencilerden tepkimeyi yazmaları, indirgenen ve yükseltgenen maddeleri belirlemeleri istenir. Ayrıca yarı tepkimelerini göstermeleri istenir).

Bakır iyonu indirgenir, hidrojen yükseltgenir.

$\mathrm{CuO}_{(\mathrm{k})}+\mathrm{H}_{2(\mathrm{~g})} \longrightarrow \mathrm{Cu}_{(\mathrm{k})}+\mathrm{H}_{2} \mathrm{O}_{(\mathrm{g})}$ 


\section{APPENDIX L}

\section{CLASSROOM OBSERVATION CHECKLIST}

\begin{tabular}{|c|c|c|c|}
\hline Sinıf Gözlem Formu & $\underset{D}{\vec{D}}$ & $\stackrel{\vec{\Xi}}{\bar{\Xi}}$ & 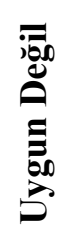 \\
\hline 1. Öğrenciler grup içi çalışma yaptılar mı? & & & \\
\hline 2. Ders bir örnek olay metninin okunmasıyla mı başladı? & & & \\
\hline 3. Öğrenme, öğretmenin konuyu anlatmasıyla mı başladı? & & & \\
\hline $\begin{array}{l}\text { 4. Öğrenciler örnek olay metni ile ilgili soruları grup içerisinde } \\
\text { cevaplandırdılar mı? }\end{array}$ & & & \\
\hline 5. Ders tartışma merkezli olarak mı yürüdü? & & & \\
\hline 6. Dersin işlenişi öğrenciyi öğrenmede sorumluluk almaya itti mi? & & & \\
\hline 7. Gruptaki her öğrenci grup çalışmasına katkıda bulundu mu? & & & \\
\hline 8. Öğrenciler fikirlerini rahatlıkla açıklayabildiler mi? & & & \\
\hline 9. Ele alınan örnek olay metni ile ilgili deney yapıldı $\mathrm{m}$ ? & & & \\
\hline 10. Tartışma sonunda ilgili kavramlar, formüller verildi mi? & & & \\
\hline 11. Öğretmen grup çalışmaları için öğrencileri cesaretlendirdi mi? & & & \\
\hline 12. Öğretmen öğrencilere düşündürücü sorular sordu mu? & & & \\
\hline $\begin{array}{l}\text { 13. Grup tartışmaları sonunda grupların fikirleri sınıfça tartışıldı } \\
\text { mı? }\end{array}$ & & & \\
\hline $\begin{array}{l}\text { 14. Grubun düşüncelerini aktaracak öğrenci öğretmen tarafından } \\
\text { rastgele seçildi mi? }\end{array}$ & & & \\
\hline 15. Öğrenciler bilgiye ulaşmaya çalıştı mı? & & & \\
\hline 16. Öğretmen öğrenciye sürekli bilgi veren konumunda mıdır? & & & \\
\hline 17. Öğrenciler derse katıldılar mı? & & & \\
\hline 18. Öğrenciler öğretmene soru sordu mu? & & & \\
\hline 19. Öğretim esnasında günlük yaşamdan örnekler verildi mi? & & & \\
\hline 20. Genel olarak, ders örnek olay metni üzerinden mi işlendi? & & & \\
\hline 21. Öğretmen, öğretim sırasında öğrencilere dönüt verdi mi?* & & & \\
\hline $\begin{array}{l}\text { *Hangi aşamalarda dönüt verildiğini açıklamalar kısmına yazınız. } \\
\text { Sınıf: } \\
\text { Tarih: } \\
\text { Ders Süresi: } \\
\text { Değerlendiren: } \\
\text { Açılamalar: }\end{array}$ & & & \\
\hline
\end{tabular}




\section{CURRICULUM VITAE}

\section{PERSONAL INFORMATION}

Surname, Name: Tarkın, Ayşegül

Nationality: Turkish (T.C.)

Date and Place of Birth: 12 July 1982, Ankara

Marital Status: Single

e-mail: aytarkin@gmail.com

\section{EDUCATION}

\section{Degree}

MS

BS

High School

\section{Institution}

Gazi University, Secondary

Science and Mathematics

Education, Chemistry Education

Gazi University, Secondary

Science and Mathematics

Education, Chemistry Education

Kurtuluş High School, Ankara
Year of Graduation

2005

2005

2000

\section{WORK EXPERIENCE}

Year

2006 - Present

\section{Place}

Middle East Technical University, Faculty of Education, Department of Secondary Science and Mathematics Education

\section{Enrollment}

Research Asisstant

\section{FOREIGN LANGUAGES}

English

\section{PUBLICATIONS}

\section{A. Papers Published in International Journals}

Aydin, S., Demirdogen, B., Tarkin, A., Kutucu, S., Ekiz, B., Akin, F. N., Tuysuz, M. \& Uzuntiryaki, E. (2013). Providing a Set of ResearchBased Practices to Support Preservice Teachers' Long-Term Professional Development as Learners of Science Teaching. Sci. Ed., 97, 903-935. doi: 10.1002/sce.21080 
Bektas, O., Ekiz, B., Tuysuz, M., Kutucu, E. S., Tarkin, A, \& UzuntiryakiKondakci, E. (2013). Pre-service Chemistry Teachers' Pedagogical Content Knowledge of the Nature of Science on the Particle Nature of Matter, Chem. Educ. Res. Pract., 14 (2), 201 - 213

Aydin, S., Demirdogen, B., \& Tarkin, A. (2012). Are They Efficacious? Exploring Pre-Service Teachers' Teaching Efficacy Beliefs during the Practicum. The Asia-Pacific Education Researcher, 21(1), 203-213.

Tarkin, A., Kutucu, E. S., Ekiz, B., Tuysuz, M., Bektas, O., \& Uzuntiryaki, E. (2011, September 5-9). Views on teaching of particulate nature of matter at macroscopic, symbolic and microscopic levels. Proceedings of European Science Education Research Association: Part 12 (pp. 195-198). Retrieved from http://lsg.ucy.ac.cy/esera/e book/base/index.html

Ekiz, B., Bektas, O., Tuysuz, M., Uzuntiryaki, E., Kutucu, E. S., \& Tarkin, A. (2011). Pre-service chemistry teachers' understanding of ionization and Dissolution. Procedia Social and Behavioral Sciences 15, 447-451.

Tuysuz, M., Ekiz, B., Bektas, O., Uzuntiryaki, Tarkin, A., \& E., Kutucu, E. S.(2011) Pre-service chemistry teachers' understanding of phase changes and dissolution at macroscopic, symbolic, and microscopic levels. Procedia Social and Behavioral Sciences 15, 452-455.

\section{B. Papers Published in National Journals}

Çapa Aydın, Y., Uzuntiryaki, E., Temli, Y., \& Tarkın, A. (2013). Özyeterlik Kaynakları Ölçeği'nin Türkçe'ye Uyarlanması İlköğretim Online, 12(3), 749-758, [Online]: http://ilkogretim-online.org.tr

Tarkın, A. \& Uzuntiryaki, E. (2012). Öğretmen Adaylarının Özyeterlik İnançları ve Mesleğe Yönelik Tutumlarının Kanonik Korelasyon Analizi ile İncelenmesi İlkögretim Online, 11(2), 332-341. [Online]: http://ilkogretim-online.org.tr

\section{Papers Presented in International Conferences}

Tarkin, A. \& Uzuntiryaki-Kondakci, E. (2014, March 30 - April 2). Promoting Students' Understanding in Electrochemistry through case-basedinstruction. Paper presented at $87^{\text {th }}$ National Association for Research in Science Teaching (NARST) Annual International Conference, Pittsburgh, PA.

Tarkin, A., Aydin, S., Demirdogen, B., \& Uzuntiryaki-Kondakci, E. (2013, September 9-13). Growing a garden with water: Enriching the teaching practice course with mentoring and explicit PCK use. Paper presented at European Conference on Educational Research (ECER), Istanbul, Turkey. 
Demirdogen, B., Tarkin, A., Aydin, S., \& Uzuntiryaki-Kondakci, E. (2013, September 9-13). Filling the gap between belief and practice: Exploring pre-service chemistry teachers $\square$ science teaching orientations in practicum. Paper presented at European Conference on Educational Research (ECER), Istanbul, Turkey.

Tarkin, A., Demirdogen, B., Aydin, S., Ekiz, B., Kutucu, E. S., Akin, F. N., Tuysuz, M. \& Uzuntiryaki-Kondakci, E. (2013, April 6-9). Providing meaningful experiences for pre-service teachers: a mentoring-enriched PCK based practicum course. Paper presented at $86^{\text {th }}$ National Association for Research in Science Teaching (NARST) Annual International Conference, Rio Grande, Puerto Rico.

Aydin, S., Demirdogen, B., \& Tarkin, A. (2013, April 6-9). Looking at the mirror: a self-study of prospective science teacher educators' pck for teaching teachers. Paper presented at $86^{\text {th }}$ National Association for Research in Science Teaching (NARST) Annual International Conference, Rio Grande, Puerto Rico.

Ekiz, B., Tuysuz, M., Bektas, O., Tarkin, A., Kutucu, E. S., \& Uzuntiryaki, E. (2012, July 15-20). How do pre-service chemistry teachers connect solubility of gases in liquids to daily life events? Paper presented at 22nd International Conference on Chemistry education - 11th European Conference on Research in Chemical Education - ICCE-ECRICE 2012. Rome, Italy.

Aydın, S., Akın, F. N., \& Tarkın, A. (2011, September 19-23). Needs Assessment for Teaching Assistants: What Do They Need to Develop Teaching Skills. Paper presented at World Conference on New Trends in Science Education (WCNTSE). Kuşadası, Türkiye.

Kutucu, E. S., Tarkin, A., Bektas, O., Ekiz, B., Tuysuz, M., \& Uzuntiryaki, E. (2011, September 5-9). Pre-service chemistry teachers' pedagogical content knowledge for nature of science on matter. Paper presented at The European Science Education Research Association-ESERA 2011. Lyon, France.

Ekiz, B., Bektas, O., Tuysuz, M., Uzuntiryaki, E., Kutucu, E. S., \& Tarkin, A. (2011, February 3-7). Pre-service chemistry teachers' understanding of ionization and Dissolution. Paper presented at the 3rd World Conference on Educational Sciences-WCES 2011. Bahcesehir University, Istanbul, Turkey.

Tuysuz, M., Ekiz, B., Bektas, O., Uzuntiryaki, Tarkin, A., \& E., Kutucu, E. S.(2011, February 3-7). Pre-service chemistry teachers' understanding of phase changes and dissolution at macroscopic, symbolic, and microscopic levels. Paper presented at the 3rd World Conference on Educational Sciences-WCES 2011. Bahcesehir University, Istanbul, Turkey. 
Tarkın, A., Temli, Y., Uzuntiryaki, E., \& Çapa Aydın, Y. (2010, Eylül 16-18). Yapılandırmacı öğretime yönelik özyeterlik ölçeği. 19. Eğitim Bilimleri Kurutayında sözlü bildiri olarak sunulmuştur. Uluslararası Kıbrıs Üniversitesi. KKTC.

Tarkin, A., \& Uzuntiryaki, E. (2009, September 28-30). Examination of preservice teachers' sense of efficacy by gender and grade level difference. Paper presented at The European Conference on Educational Research-ECER 2009. University of Vienna,Vienna-Austria.

Aydın, S., Demirdogen, B., Tarkin, A., \& Uzuntiryaki, E. (2009, August 31September 4). Effectiveness of a Course on Pre-Service Chemistry Teachers' Pedagogical Content Knowledge and Subject Matter Knowledge. Paper presented at The European Science Education Research Association-ESERA 2009. Istanbul, Turkey.

Tarkin, A., \& Uzuntiryaki, E. (2008, July 6-9). Preservice chemistry teachers' sense of teacher efficacy and their attitudes toward teaching as a profession. Paper presented at the 9th European Conference on Research In Chemical Education- ECRICE 2008. Istanbul, Turkey.

\section{Papers Presented in National Conferences}

Tüysüz, M., Tarkın, A., Kutucu, E. S., Ekiz, B., Aydın, S., Demirdöğen, D., \& Uzuntiryaki, E. (2012, Haziran 27-30). Kimya Öğretmen Adaylarının Kimya Eğitimine Yönelik Sorunlara Bakışı ve Çözüm Önerileri. X. Ulusal Fen Bilimleri ve Matematik Eğitimi Kongresinde sözlü bildiri olarak sunulmuştur. Niğde Üniversitesi, Niğde, Türkiye.

Tarkın, A., Tanık, N., Bektaş, O., \& Saraçoğlu, S. (2012, Haziran 27-30). Fen bilgisi öğretmen adaylarının fen ve teknoloji okuryazarlığı hakkındaki düşünceleri. X. Ulusal Fen Bilimleri ve Matematik Eğitimi Kongresinde sözlü bildiri olarak sunulmuştur. Niğde Üniversitesi, Niğde, Türkiye.

Tanık, N., Bektaş, O., Tarkın, A., \& Saraçoğlu, M. (2012, Haziran 27-30). Fen bilgisi öğretmen adaylarının polar kovalent bağlı maddelerin kaynama nokytalarını kıyaslarken kullandıkları zihinsel modeller. X. Ulusal Fen Bilimleri ve Matematik Eğitimi Kongresinde sözlü bildiri olarak sunulmuştur. Niğde Üniversitesi, Niğde, Türkiye.

Tarkın, A., Demirdöğen, B., \& Aydın, S.(2010, Eylül 23-25). Kimya öğretmen adaylarının özyeterlik inançları. IX. Ulusal Fen Bilimleri ve Matematik Eğitimi Kongresinde sözlü bildiri olarak sunulmuştur. Dokuz Eylül Üniversitesi, İzmir, Türkiye.

\section{E. Posters Presented in International Conferences}

Tuysuz, M., Bektas, O., Tarkin, A., Kutucu, E. S., Ekiz, B., \& Uzuntiryaki, E. (2012, July 15-20). Pre-service chemistry teachers' instructional designs of 5E learning cycle model on intermolecular forces. Paper 
presented at 22nd International Conference on Chemistry education 11th European Conference on Research in Chemical Education - ICCEECRICE 2012. Rome, Italy.

Tarkin, A., Kutucu, E. S., Ekiz, B., Tuysuz, M., Bektas, O., \& Uzuntiryaki, E. (2011, September 5-9). Views on teaching of particulate nature of matter at macroscopic, symbolic and microscopic levels. Paper presented at The European Science Education Research AssociationESERA 2011. Lyon, France.

Tarkin, A., Aydın, S., Uzuntiryaki, E., \& Boz, Y. (2009, August 31- September 4). An Examination on Pre-Service and In-Service Teachers' Sense of Efficacy Beliefs. Poster presented at The European Science Education Research Association-ESERA 2009. Istanbul, Turkey.

\section{F. Posters Presented in National Conferences}

Akın, F. N., Tarkın, A., \& Aydın, S. (2011, Temmuz 5-8). İyi Bir Kimya Eğitimcisi Ne Tür Bilgilere Sahip Olmalıdır? II. Ulusal Kimya Eğitimi Kongresi'nde poster olarak sunulmuştur. Erzurum, Türkiye.

Demirdöğen, B., Aydın, S., \& Tarkın, A. (2010, Eylül 23-25). Kimya öğretmen adaylarının öğretmen yeterlikleri hakkındaki görüşleri. IX. Ulusal Fen Bilimleri ve Matematik Eğitimi Kongresinde poster olarak sunulmuştur. Dokuz Eylül Üniversitesi, İzmir, Türkiye.

Aydın, S., Tarkin, A., \& Demirdöğen, B. (2010, Eylül 23-25). Öğretmen adaylarının mikro öğretim ile zenginleştirilmiş öğretmenlik uygulaması dersi hakkındaki görüşleri. IX. Ulusal Fen Bilimleri ve Matematik Eğitimi Kongresinde poster olarak sunulmuştur. Dokuz Eylük Üniversitesi, İzmir, Türkiye.

Aydın, S., Tarkin, A., \& Boz, Y. (2010, Eylül 23-25). Kimya öğretmen adaylarının kullanmakta kendilerini yetersiz hissettikleri öğretim yöntemleri ve bu durumun nedenleri. IX. Ulusal Fen Bilimleri ve Matematik Eğitimi Kongresinde poster olarak sunulmuştur. Dokuz Eylük Üniversitesi, İzmir, Türkiye.

\section{AWARDS}

National Association for Research in Science Teaching Scholarship Winner in 2013.

\section{PROFESSIONAL MEMBERSHIP}

National Association for Research in Science Teaching (NARST)

Turkish Science Education and Research Association (SERA)

\section{HOBBIES}

Tennis, gym, movies, books, mind games. 